\title{
Edukacja włączająca \\ w przedszkolu i szkole
}

$\because$ SERIA NAUKOWA

Redakcja naukowa

Iwona Chrzanowska, Grzegorz Szumski
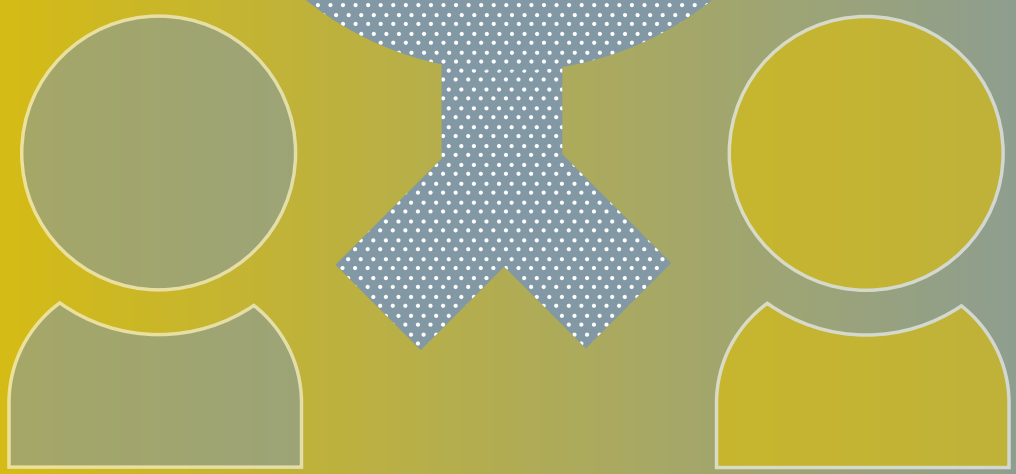
Edukacja włączająca w przedszkolu i szkole 



\section{Edukacja włączająca w przedszkolu i szkole}

Redakcja naukowa

Iwona Chrzanowska

Grzegorz Szumski 
SERIA NAUKOWA, TOM 7

Edukacja włączająca w przedszkolu i szkole

Redaktorzy naukowi: prof. dr hab Iwona Chrzanowska dr hab., prof. UW Grzegorz Szumski

Współpraca: $\quad$ Agnieszka Rybińska

Recenzent: $\quad$ prof. dr hab. Zenon Gajdzica

Redaktor prowadzący: Tomasz Mrożek

Korekta: Beata Bociąg (EDITIO), Marcin Grabski (mesem.pl)

Tłumaczenie

z języka angielskiego: Poliglota

Projekt graficzny: Diana Makulska/Podpunkt

Projekt okładki i skład: Artur Ładno, Mariusz Skarbek

Druk: Multigraf Drukarnia Sp. z o.o. Bydgoszcz

Wydawca: $\quad$ Fundacja Rozwoju Systemu Edukacji

Narodowa Agencja Programu Erasmus+

Al. Jerozolimskie 142a, 02-305 Warszawa

www.frse.org.pl | kontakt@frse.org.pl

(C) Fundacja Rozwoju Systemu Edukacji, Warszawa 2019

ISBN: 978-83-65591-83-8

Publikacja została wydana przy wsparciu finansowym Komisji Europejskiej w ramach programu Erasmus+. Publikacja odzwierciedla jedynie stanowisko jej autorów i Komisja Europejska nie ponosi odpowiedzialności za zamieszczoną w niej zawartość merytoryczną.

Publikacja bezpłatna
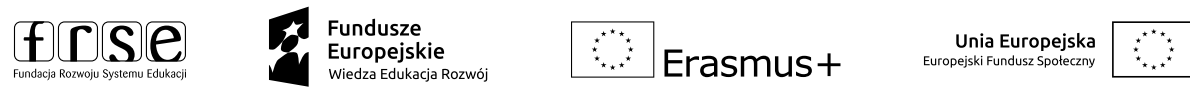

Cytowanie:

Edukacja włączająca w przedszkolu i szkole, I. Chrzanowska, G. Szumski (red. nauk.), Fundacja Rozwoju Systemu Edukacji, Seria Naukowa, t. 7, Warszawa 2019.

Publikacje Wydawnictwa FRSE: www.czytelnia.frse.org.pl 


\section{Spis treści}

9

Wstęp

Edukacja włączająca - podstawy teoretyczne

14

1.1. Koncepcja edukacji włączającej

Grzegorz Szumski

1.2. Rozwój edukacji włączającej w Europie:

strategie mające na celu podnoszenie osiągnięć

wszystkich uczących się

Anthoula Kefallinou, Verity Donnelly

1.3. Edukacja włączająca w badaniach naukowych

- perspektywa nauczyciela

1.3.1. Postawy wobec edukacji włączającej - jakie skutki?

Iwona Chrzanowska

54.

1.3.2. Kompetencje zawodowe - jakie wyzwania?

Iwona Chrzanowska, Grzegorz Szumski

62

1.3.3. Zróżnicowane grupy uczniów - jakie problemy?

Grzegorz Szumski 
1.4. Edukacja włączająca w badaniach naukowych

- perspektywa ucznia

72

1.4.1. Osiągnięcia szkolne - jakie uwarunkowania?

Grzegorz Szumski

78

1.4.2. Kompetencje społeczne - jakie szanse?

Grzegorz Szumski

84

1.4.3. Relacje rówieśnicze - jakie zagrożenia?

Iwona Chrzanowska

92

1.5. Edukacja włączająca w badaniach naukowych

- perspektywa rodzica

Iwona Chrzanowska

\section{Edukacja włączająca w praktyce}

- czy nowy model przedszkola/szkoły?

108

2.1. Dostępne przedszkole, dostępna szkoła - co to znaczy?

Grażyna Małachowska, Marek Tarwacki

124

2.2. Finansowanie zadań oświatowych w edukacji włączającej

Liliana Zientecka

138

2.3. Nauczyciel w edukacji włączającej

Beata Jachimczak 


\subsection{Uczeń w edukacji włączającej}

162

2.4.1. Diagnoza - obszary, sposoby, narzędzia

Marzenna Czarnocka

174

2.4.2. Wsparcie - instrumenty, zobowiązania systemowe, formalne i nieformalne formy

Elżbieta Neroj

208

2.4.3. Uniwersalne projektowanie zajęć jako droga do zaspokajania zróżnicowanych potrzeb edukacyjnych

Katarzyna Cichocka-Segiet, Piotr Mostowski, Pawet Rutkowski

218

2.4.4. Kształtowanie pozytywnych relacji uczniów w edukacji włączającej

Jacek Pyżalski

228

2.4.5. Ocenianie ksztaltujące - ocenianie wspierające uczniów ze specjalnymi potrzebami edukacyjnymi

Urszula Skrzypczak

2.4.6. Start w dorosłość - uwarunkowania, wyznaczniki oraz proces przejścia z edukacji do rynku pracy uczniów ze specjalnymi potrzebami edukacyjnymi

Wojciech Otrębski

2.5. Rodzic w edukacji włączającej jako współuczestnik procesu Beata Rola

\section{4}

2.6. Nowa rola placówek specjalnych

Anna Tomaszewska 
Wspólna przestrzeń - wspólne problemy - wspólne rozwiązania. Doświadczenia praktyków

278

3.1. Różnorodność i inkluzja w edukacji - wybrane aspekty wspierania uczniów z doświadczeniem migracji

Anna Młynarczuk-Sokotowska, Katarzyna Szostak-Król

288

3.2. Nie marnujmy talentów! Wspieranie uczniów zdolnych w praktyce edukacyjnej

Tomasz Knopik

298

Bibliografia

329

Dokumenty 


\section{Wstęp}

Na polskim rynku wydawniczym nie brakuje wartościowych publikacji poświęconych wspólnemu nauczaniu osób ze specjalnymi potrzebami edukacyjnymi (SPE) i osób bez takich potrzeb. Systematyczny rozwój tego typu praktyk, a także przełomowy charakter samej idei sprawiły, że wielu naukowców interesuje się wspólnym nauczaniem i publikuje wyniki swoich badań na ten temat. Uznaliśmy jednak, że nadal jest przestrzeń na nową książkę dotyczącą wspólnego nauczania wszystkich uczniów.

W odróżnieniu od większości dostępnych wydawnictw i artykułów nasza publikacja nie jest poświęcona wspólnemu nauczaniu jako takiemu, lecz jego najnowszemu ujęciu, znanemu pod nazwą edukacji włączającej. Takie zawężenie zakresu zostało zasygnalizowane $w$ tytule. Koncepcja edukacji włączającej dotyczy wspólnego kształcenia uczniów z niepełnosprawnościami i bez nich, ale w żadnym wypadku nie wyczerpuje zagadnienia wspólnej nauki. Idea ta jest zatem nie tylko czołowym paradygmatem pedagogiki specjalnej, ale także, a może przede wszystkim, najbardziej wpływową wizją szkoły publicznej, która przeciwstawia się neoliberalnemu rozumieniu edukacji. Edukacja włączająca jest więc projektem szkoły, która nie wyklucza uczniów z powodu jakichkolwiek ich cech. Silnie przeciwstawia się redukowaniu celów kształcenia do wąsko rozumianych osiągnięć szkolnych i rozwoju poznawczego. Zakłada potrzebę wspierania harmonijnego, zrównoważonego rozwoju uczniów, na który składają się nie tylko osiągnięcia akademickie, ale także rozwój społeczno-emocjonalny oraz ogólny dobrostan psychospołeczny.

Większość dostępnych na polskim rynku wydawniczym publikacji na temat wspólnego nauczania uczniów ze specjalnymi potrzebami edukacyjnymi i bez takich potrzeb jest silnie ukierunkowana na badania 
podstawowe. Ich autorzy podejmowali wysiłki służące poznaniu istoty, uwarunkowań i pedagogicznych następstw kształcenia integracyjnego oraz edukacji włączającej. Dużo mniej publikacji poświęconych jest opisowi zmiany szkoły i systemu kształcenia w takim kierunku, aby umożliwić realizację edukacji włączającej. Tymczasem w literaturze światowej już od co najmniej dwóch dekad silnie akcentuje się to, że powinna być ona rozumiana jako proces nieustannych reform szkolnictwa, nie zaś jako stan. Oczekuje się zatem, że badania naukowe będą poświęcone przemianom szkół w kierunku placówek włączających, przede wszystkim jednak, że będą wspomagały przemiany tego typu. Przygotowanie publikacji tego rodzaju było naszym zamierzeniem. Mamy nadzieję, że chociaż częściowo udało się nam ten zamysł zrealizować.

Pomysł opracowania książki, która będzie wspomagała przemiany polskiej szkoły w kierunku edukacji włączającej, zrodził się w kręgu członków zespołu powołanego przez ministra edukacji narodowej w celu przygotowania modelu kształcenia uczniów ze specjalnymi potrzebami edukacyjnymi w Polsce. Ponieważ uznaliśmy, że przyszła reforma powinna zmieniać polski system szkolny zgodnie z założeniami koncepcji edukacji włączającej, zakres proponowanych przez nas zmian wykracza poza kształcenie uczniów ze specjalnymi potrzebami, a tym bardziej z oficjalną diagnozą o potrzebie kształcenia specjalnego. Jesteśmy przekonani, że w ostatnich trzech dziesięcioleciach osiągnięto znaczny postęp $w$ rozbudowie systemów specjalistycznego wsparcia edukacyjno-terapeutycznego, przeznaczonego dla uczniów z zaburzeniami rozwoju. Jednak dalsze doskonalenie systemu powinno koncentrować się w mniejszym stopniu na poszerzaniu dodatkowej pomocy specjalistycznej, a w większym na rozwoju samych szkół. Takie podejście do edukacji włączającej staraliśmy się także prezentować w niniejszej publikacji.

Książka składa się z trzech części. Pierwsza ma najbardziej teoretyczny i wprowadzający charakter. Prezentujemy w niej aktualny stan prac badawczych na temat kluczowych aspektów edukacji włączającej. Omawiając krytycznie najnowsze wyniki badań, staraliśmy się uwzględnić perspektywę kluczowych aktorów edukacji włączającej: uczniów, nauczycieli i rodziców.

Część druga poświęcona jest analizie modelu szkoły i przedszkola włączającego. Ma ona bardziej praktyczny charakter. Jej autorzy pokazują rozwiązania finansowe, organizacyjne i pedagogiczne, które 
służą przekształcaniu się szkół i przedszkoli w placówki włączające. Opisane propozycje są rezultatem zarówno aplikacji wyników badań, jak i generalizacji udanych doświadczeń praktycznych. Analizy zamieszczone w tej części składają się na pożądany model funkcjonowania szkolnictwa, zgodny ze współczesną wizją edukacji włączającej.

W trzeciej części prezentowane są rozwiązania służące zaspokajaniu potrzeb uczniów wybitnie zdolnych, a także migrantów w placówkach edukacyjnych.

Standardy edytorskie wydawcy obejmują zarówno abstrakty, jak i słowa kluczowe do poszczególnych części. Takie rozwiązanie znacznie ułatwi czytelnikom zorientowanie się $\mathrm{w}$ strukturze pracy i korzystanie z niej. Książka kierowana jest do szerokiego grona badaczy, studentów, polityków oświatowych i nauczycieli, którym bliska jest koncepcja edukacji włączającej jako permanentnego ruchu reformy szkolnictwa w kierunku harmonijnego, zrównoważonego rozwoju wszystkich uczniów.

Książka powstała dzięki współpracy szerokiego grona autorów. Wszystkim, którzy zechcieli wziąć udział w tym projekcie, składamy serdecznie podziękowania za owocną współpracę. Osobne podziękowania składamy prof. dr. hab. Zenonowi Gajdzicy za ciepłe słowa o książce, a przede wszystkim za cenne wskazówki, które pozwoliły nam ją udoskonalić.

Iwona Chrzanowska

Grzegorz Szumski

(redaktorzy naukowi) 


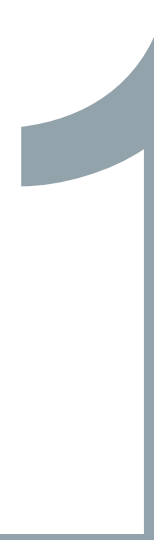

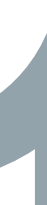




\section{Edukacja włączająca \\ - podstawy teoretyczne}




\subsection{Koncepcja edukacji włączającej}

Grzegorz Szumski

Edukacja włączająca nie jest jednolitą koncepcją teoretyczną i praktyczną, ale różne sposoby jej rozumienia wzajemnie się uzupełniają. We współczesnej pedagogice specjalnej pojęcia tego używa się w znaczeniu deskryptywnym i preskryptywnym. W pierwszym wypadku chodzi o każdą formę wspólnej nauki uczniów z niepełnosprawnościami i bez nich w jednej klasie. W znaczeniu drugim edukacja włączająca jest projektem reformy systemu oświatowego, który ma na celu zbudowanie szkoły wysokiej jakości dla wszystkich uczniów. Koncepcję edukacji włączającej dokładniej charakteryzują następujące cechy: dostęp do szkoły dla wszystkich uczniów, zrównoważone cele kształcenia, uwzględniające harmonijny rozwój uczniów, elastyczny system wsparcia współpracujących ze sobą specjalistów oraz wspólny program kształcenia.

\section{Słowa kluczowe:}

\section{edukacja włączająca}




\subsection{Conception of inclusive education}

Grzegorz Szumski

Inclusive education is not a homogeneous theoretical and practical conception, but different ways of its understanding complement each other. In a contemporary special education a notion of inclusive education is used in a descriptive and prescriptive meaning. In the first meaning, it is a form of common learning of students with and without disabilities in one classroom. In the latter, inclusive education is a project of school system reform, which aim is to built a common, high-quality school for all students. A conception of inclusive education is accurately define by such features as: access to a common school for all students, balanced educational aims, concerning harmonious development of students, flexible system of support of specialists cooperating with each other, and common curriculum.

\section{__ Keywords: \\ inclusive education \\ educational aims \\ cooperation of specialists


Termin "edukacja włączająca" pojawił się w literaturze pedagogicznej na początku lat 90 . XX w. i bardzo szybko zdobył sporą popularność. Choć początkowo pojęcie to wykorzystywano przede wszystkim w naukowych i społecznych debatach w Stanach Zjednoczonych i Kanadzie, to dziś jest ono kluczowym terminem nauk o wychowaniu i przedmiotem debat polityczno-oświatowych na całym świecie. Już na tej podstawie można wnioskować, że określenie to niesie ważne treści i odnosi się do istotnych kwestii współczesnych systemów szkolnych. Jednocześnie jest ono bardzo wieloznaczne, co wywołuje wiele niepotrzebnych nieporozumień. W tym rozdziale podejmiemy próbę usystematyzowania znaczeń nadawanych edukacji włączającej, wskażemy niektóre przyczyny niejednoznaczności tego terminu, przede wszystkim jednak postaramy się omówić jej pedagogiczną wartość oraz zawarte w niej przesłanie.

Jak trafnie podkreślają Peter Farrell, Alan Dyson, Filiz Polat, Grame Hutcheson i Frances Gallannaugh (2007), w literaturze można spotkać dwa podstawowe sposoby posługiwania się określeniem „edukacja włączająca". W szerszym ujęciu odnosi się ono do sytuacji, w której uczniowie z niepełnosprawnością lub ze specjalnymi potrzebami edukacyjnymi (SPE) kształceni są w szkołach głównego nurtu i spędzają większość czasu w klasach, w których liczebnie dominują uczniowie bez niepełnosprawności. Tego typu definicje mają charakter opisowy, a zatem odnoszą się do rzeczywiście występujących w większości systemów szkolnych form organizacji kształcenia. Zawierają też względnie (choć nie w pełni) jasne kryteria definicyjne, a zatem pozwalają intersubiektywnie wyodrębnić edukację włączającą od innych form organizacji kształcenia uczniów z niepełnosprawnością, powszechnie zwanych segregacyjnymi. Warto również zwrócić uwagę, że tak rozumiana edukacja włączająca obejmuje swoim zakresem rozwiązania, które mają co prawda istotne elementy wspólne, ale jednocześnie bardzo dużo cech różnych. W tym kontekście kryteria edukacji włączającej spełniają w Polsce klasy zarówno integracyjne, jak i ogólnodostępne, do których uczęszczają uczniowie z orzeczeniem o potrzebie kształcenia specjalnego. Definicja edukacji włączającej w szerokim, deskryptywnym rozumieniu nie odnosi się do wielu cech szczegółowych kształcenia uczniów bez niepełnosprawności i z niepełnosprawnościami w jednej klasie szkolnej, które bardzo interesują pedagogów specjalnych, polityków edukacyjnych i rodziców. Abstrahuje 
ona zwłaszcza od problemu rejonowości szkoły, zakresu i sposobów udzielania specjalnej pomocy pedagogicznej uczniom z niepełnosprawnością lub SPE, ich dostępu do ogólnego programu kształcenia, a wreszcie celów edukacji szkolnej i jej jakości.

Mimo tych ograniczeń szerokie rozumienie edukacji włączającej jest bardzo często wykorzystywane, zwłaszcza w badaniach empirycznych. Dzieje się tak z co najmniej dwóch powodów. Po pierwsze, ujęcie takie ma uzasadnienie historyczne. Gdy termin ten pojawił się w amerykańskiej debacie o kształceniu uczniów z niepełnosprawnością, był on przede wszystkim skierowany przeciwko bardzo rozpowszechnionej w Stanach Zjednoczonych i niektórych innych krajach praktyce tzw. kształcenia mieszanego. Polega ono na tym, że uczniowie z niepełnosprawnością uczęszczają wprawdzie do szkół ogólnodostępnych, ale znaczna część ich edukacji odbywa się w małych, homogenicznych grupach poza klasą lub, o wiele rzadziej, w trybie nauczania indywidualnego na terenie szkoły (Powell 2011). W istocie kształcenie takie jest swoistą hybrydą - kombinacją specyficznych klas specjalnych z nauczaniem we wspólnej klasie szkolnej. Wyeliminowanie tej formy kształcenia, a przynajmniej ograniczenie liczby uczniów nią objętych i czasu spędzanego przez nich poza heterogeniczną klasą, było głównym postulatem twórców i zwolenników koncepcji edukacji włączającej, a samo określenie miało nie obejmować swoim zakresem tego typu praktyk. W rzeczywistości całkowite wyeliminowanie procesu wyprowadzania uczniów z niepełnosprawnością z heterogenicznej klasy okazało się jak dotąd niemożliwe w wielu systemach szkolnych, stąd w definicji włączania pojawiło się nieostre kryterium „dominującego miejsca kształcenia". Z tego powodu niektórzy badacze mówią o stopniowalności edukacji włączającej. Conrad Oh-Young i John Filler (2015) w najnowszej metaanalizie poświęconej znaczeniu form kształcenia dla osiągnięć szkolnych i kompetencji społecznych porównywali uczniów z form bardziej i mniej włączających, przyjmując za kryterium stopniowania "okazje do interakcji z uczniami bez niepełnosprawności", a zatem czas spędzany we wspólnej przestrzeni klasy, a nawet szkoły.

Drugim powodem popularności tego podejścia jest to, że jest jedynym, które ma charakter deskryptywny. Pozwala zatem względnie łatwo i precyzyjnie definiować zakres badań lub przedmiot debat.

W znaczeniu węższym funkcjonują różne sposoby rozumienia edukacji włączającej. Wszystkie mają jedną, kluczową cechę wspól- 
ną - są preskryptywne. Oznacza to, że nie opisują istniejących praktyk edukacyjnych, tylko mniej lub bardziej skonkretyzowane wizje takich praktyk, swoiste typy idealne. Ich kluczową funkcją jest inspirowanie zmian w szkolnictwie, w tym w kształceniu uczniów ze specjalnymi potrzebami edukacyjnymi. Kerstin Göransson i Claes Nilholm (2014) wykazali, że istnieją trzy tego typu podejścia do edukacji włączającej, które rozwijały się w porządku chronologicznym. Pierwsze z nich można sprowadzić do adekwatnego zaspokojenia potrzeb wszystkich uczniów z niepełnosprawnością w szkole ogólnodostępnej, drugie - do adekwatnego zaspokojenia potrzeb wszystkich uczniów, trzecie - do zbudowania w szkole, a właściwie wokół niej, wspólnoty o specyficznych właściwościach. W tym rozdziale skoncentrujemy się na pierwszym z tych ujęć, czyli na włączaniu uczniów z niepełnosprawnością. Trochę uwagi poświęcimy także edukacji włączającej jako nowej koncepcji szkoły wspólnotowej, lepiej dostosowanej do potrzeb wszystkich uczniów i nowoczesnego społeczeństwa. Aby uporządkować wywód będziemy analizowali problem na pięciu podstawowych płaszczyznach: dostępu do edukacji powszechnej, celów edukacji szkolnej, specjalnego wsparcia i współpracy różnych grup specjalistów w zaspokajaniu potrzeb uczniów oraz programu kształcenia.

Znaczenia edukacji włączającej nie sposób zrozumieć, marginalizując problem prawa dostępu osób z niepełnosprawnością do powszechnej, publicznej edukacji, a w praktyce do szkoły, do której mają dostęp uczniowie bez niepełnosprawności. Przez długie lata kwestia ta dominowała w debacie o edukacji włączającej (Dyson 2000), ale z czasem ugruntowało się przekonanie, że ograniczanie dostępu do powszechnej, wspólnej dla wszystkich szkoły ma charakter dyskryminujący i jest niesprawiedliwe. Pogląd ten znalazł także odzwierciedlenie w międzynarodowych dokumentach prawnych, przede wszystkim w Konwencji o prawach osób niepełnosprawnych, przyjętej przez Zgromadzenie Ogólne Narodów Zjednoczonych w 2006 r. i ratyfikowanej przez Polskę. Artykuł 24 Konwencji jednoznacznie wskazuje, że edukacja włączająca na wszystkich poziomach edukacyjnych jest sposobem zapobiegania dyskryminacji w kształceniu osób z niepełnosprawnością. W odróżnieniu od wcześniejszych dokumentów o podobnej randze i zasięgu, takich jak Standardowe zasady wyrównywania szans osób niepełnosprawnych (ONZ 1993) czy Deklaracja z Salamanki (1994), w Konwencji nie wspomina się o alternatywnych ścieżkach kształcenia osób z niepełnospraw- 
nością, które mogłyby mieć uzasadnienie w niektórych sytuacjach. Tym samym dokument ten usuwa na margines toczący się przez lata spór o to, czy wspólne nauczanie jest efektywniejszą metodą zaspokajania potrzeb edukacyjnych uczniów z niepełnosprawnością niż tradycyjne szkolnictwo specjalne. Nie znaczy to, że dysponujemy jednoznacznymi, mocnymi dowodami empirycznymi wskazującymi na przewagę jakości edukacji włączającej nad kształceniem w szkołach specjalnych. Konwencja jest jednak wyraźnym impulsem do przekierowania myślenia i wysiłków polityków, nauczycieli, pedagogów specjalnych i badaczy na poszukiwanie odpowiedzi na pytanie, jak należy zmieniać szkołę powszechną, aby zapewniała ona optymalne warunki nauki i efekty kształcenia wszystkim uczniom, w tym także osobom z niepełnosprawnością. Sprzyja zatem pojmowaniu edukacji włączającej jako ustawicznego ruchu reformy szkoły, doskonalenia jej wewnętrznej organizacji i klimatu, sposobu dystrybuowania i wykorzystania zasobów oraz metod nauczania i wychowania (Ainscow, Booth, Dyson 2006).

Postulat zbudowania szkoły dostępnej dla wszystkich uczniów tworzy oczywistą okazję do ponownego przemyślenia celów edukacji szkolnej. W ostatnich dekadach nastąpiło wyraźne przesunięcie punktu ciężkości na indywidualne osiągnięcia uczniów i konkurencję, co jest wynikiem implementacji neoliberalnego myślenia o kształceniu. Proces ten bardzo wyraźnie dotknął także polską edukację. Można zakładać, że tak zorientowana szkoła sprzyja podnoszeniu osiągnięć edukacyjnych uczniów z niepełnosprawnością bardziej niż placówka specjalna i istnieją stosowne dowody empiryczne wspierające tę tezę (Kurz, Elliott, Lemons, Zigmond, Kloo 2014).

Poprawa wiedzy i umiejętności uczniów z niepełnosprawnością jest oczywiście korzystna dla ich samorealizacji i włączenia w życie społeczne. Jednak może okazać się niewystarczająca. Koncepcja edukacji włączającej zakłada zatem poszerzenie sposobu rozumienia celów nauki szkolnej. Lansowany model obejmuje cele bardziej zrównoważone, które - obok osiągnięć edukacyjnych - obejmują także rozwój wartości wspólnotowych, dobrych relacji między uczniami, bezpieczeństwa i jakości życia w szkole (Forlin 2010). Wydaje się, że postulaty te są bardzo aktualne również obecnie. W ostatnich latach wyobrażenie, że głównym mechanizmem rozwoju jest konkurencja i rywalizacja, do której powinna przygotowywać szkoła, zostało wielokrotnie podważone. Diagnozy stanu polskiego społeczeństwa pokazują, że poważnymi 
barierami rozwojowymi są: niski poziom zaufania, brak umiejętności współpracy w heterogenicznych zespołach oraz umiejętności budowania wspólnoty (Czapiński, Panek 2015).

Kwestia specjalistycznego wsparcia uczniów z niepełnosprawnością w edukacji włączającej jest kluczową przeszkodą w zrozumieniu tej koncepcji. Duża liczba osób zajmujących się problematyką włączania, a przede wszystkim spora grupa rodziców, nauczycieli i dyrektorów szkół wyraża pogląd, że sukces we włączaniu uczniów z niepełnosprawnością zależy przede wszystkim od zapewnienia im wsparcia specjalistów, czyli nauczycieli pedagogów specjalnych oraz różnego rodzaju terapeutów (Gajdzica 2013). Warto zwrócić uwagę, że przekonanie to jest oparte na założeniu, że osoby z niepełnosprawnością uczą się inaczej niż osoby sprawne, a to z kolei jest przesłanką do realizowania kształcenia segregacyjnego. Tymczasem podstawą teoretyczną edukacji włączającej jest sformułowana wiele lat temu przez Aleksandra Hulka teza, że potrzeby edukacyjne osób sprawnych i osób z różnego rodzaju niepełnosprawnościami są w znacznej mierze wspólne. Nie znaczy to oczywiście, że są takie same, choć - co trzeba podkreślić - znaczne różnice $w$ tym zakresie występują także między uczniami bez niepełnosprawności. Zgodnie z tymi wnioskami koncepcja edukacji włączającej zakłada, że za kształcenie uczniów z niepełnosprawnością powinni być odpowiedzialni nauczyciele wspierani przez intensywnie z nimi współpracujących pedagogów specjalnych i terapeutów oraz przez interdyscyplinarne zespoły specjalistów. Obie wspomniane możliwości należy traktować jako uzupełniające, a nie alternatywne.

Mamy coraz więcej dowodów na to, że nadmiar specjalistów jest niekorzystny dla włączania uczniów z niepełnosprawnością. Prowadzi on do znacznego obciążania ich dodatkowymi zajęciami (których skuteczność jest często wątpliwa) oraz rozdzielania wspólnego procesu nauczania w klasie szkolnej. Pedagodzy specjalni mogą wyuczać podopiecznych bezradności edukacyjnej, a także stanowić przeszkodę w interakcji z rówieśnikami bez niepełnosprawności. Bardzo mało wiemy na temat realnego zapotrzebowania na tego rodzaju specjalistów w szkołach włączających. Jesse C. Suter i Michael F. Giangreco (2009) dowodzą, że szkoły, w których 100 uczniów przypada na jednego pedagoga specjalnego, są obarczone ryzykiem niewydolności we włączaniu, a szkoły, w których pedagog zajmuje się 120 podopiecznymi, już są niewydolne w tym zakresie. Należy jednak pamiętać, że dane dotyczą 
systemu szkolnego w Stanach Zjednoczonych i mają jedynie charakter orientacyjny w zakresie analizy zapotrzebowania na pedagogów specjalnych w innych krajach. Kluczową kwestią jest przy tym elastyczność. W niektórych klasach nie wystarczy obecność nauczyciela i pedagoga specjalnego, w związku z czym konieczne jest zatrudnienie dodatkowej osoby. Zdarzają się jednak sytuacje, w których sprawdzi się nauczyciel wspomagający w niepełnym wymiarze czasu. Nie lekceważąc problemu dostępu szkół włączających do kadry kształcenia specjalnego, należy podkreślić, że kluczowe znaczenie ma sposób jej wykorzystania, szczególnie zaś dobra współpraca interdyscyplinarnych zespołów zarówno w szkole, jak i w klasie.

Największą przeszkodą w realizacji edukacji włączającej o wysokiej jakości jest traktowanie kształcenia uczniów z niepełnosprawnością jako odrębnego zadania, dodatkowego programu. Dzieje się tak wtedy, gdy nauczyciele nie czują się odpowiedzialni za edukację uczniów z orzeczeniami i powierzają to zadanie pedagogom specjalnym, a jednocześnie nie dopuszczają do tego, by mogli mieć oni wpływ na organizację procesu kształcenia całej klasy. Teza ta ma nie tylko silne uzasadnienie teoretyczne (Erten, Savage 2012), ale potwierdzają ją liczne dowody empiryczne (McLeskey, Waldron, Reed 2014; Solis, Vaughn, Swanson, McCulley 2012).

Ze sposobem wykorzystania pedagogów specjalnych w edukacji włączającej bezpośrednio związana jest kwestia programu nauczania. Program, obejmujący swoim zakresem nie tylko cele i treści kształcenia, ale także metody wspomagające nabywanie wiedzy i umiejętności przez uczniów, jest bardzo ważnym elementem koncepcji edukacji włączającej. Obok nowego sposobu wykorzystania pedagogów specjalnych w szkole ogólnodostępnej, a właściwie wyobrażenia personelu merytorycznego jako ściśle współpracującego ze sobą wielospecjalistycznego zespołu, program jest kluczowym elementem szkoły włączającej. Wielu autorów zwraca uwagę na to, że w tego rodzaju placówce uczniowie z niepełnosprawnością są z reguły konfrontowani z trudniejszym materiałem nauczania, stawia im się większe wymagania w tym obszarze i koncentruje się na nauczaniu treści akademickich. Przywoływany już Aleksander Kurz i współpracownicy (2014) empirycznie wykazali, że w szkołach specjalnych nauczyciele krócej zajmują się aktywnościami związanymi z osiąganiem celów programowych, a także kładą mniejszy nacisk na rozwój procesów poznawczych i analizę postępów 
w nauce poszczególnych uczniów (oraz na udzielanie im precyzyjnych informacji na ten temat). Co prawda potrzebujemy dalszych badań na temat różnic w realizacji programu kształcenia w szkołach specjalnych i włączających, ale już dziś mamy silne dowody na to, że edukacja włączająca sprzyja zwiększeniu dostępu osób z niepełnosprawnościami do wykształcenia na wyższym poziomie i do bardziej prestiżowych miejsc pracy (Chesmore, Ou, Reynolds 2016; Szumski, Firkowska-Mankiewicz, Lebuda, Karwowski 2018).

Realizacja wspólnego, elastycznego programu kształcenia w heterogenicznych klasach wymaga zarówno od nauczycieli, jak i od pedagogów specjalnych porzucenia tradycyjnych sposobów edukacyjnych, zwłaszcza frontalnego przekazywania wiedzy za pomocą metod podających. To z kolei otwiera w klasach przestrzeń do upowszechnienia konstruktywistycznego modelu kształcenia. Szczególnie zalecane są różne warianty pracy uczniów w heterogenicznych grupach i parach, w tym tutoring rówieśniczy, a także rozwiązania uelastyczniające przebieg lekcji (np. stacje zadaniowe). Metody te są zgodne z koncepcją nabywania wiedzy przez jej społeczne konstruowanie, a ich wysoka efektywność została potwierdzona w wielu badaniach i metaanalizach (por. Mitchell 2016). Badacze zwracają przy tym uwagę, że zwiększenie liczby dorosłych w klasie szkolnej sprzyja stosowaniu tego typu rozwiązań. Liczniejszy personel pedagogiczny łatwiej może przygotować zróżnicowane zadania do prac w grupach i parach, a także lepiej kontrolować aktywność dzieci podczas wspólnych prac, motywować uczniów i udzielać im wsparcia, kiedy pojawią się problemy (Muijs, Reynolds 2003). Jednocześnie należy zwrócić uwagę, że przeszkodą we wdrażaniu tego typu rozwiązań mogą być silne tradycje nauczania podającego i frontalnego oraz brak czasu na wspólne planowanie lekcji przez nauczycieli i pedagogów specjalnych. Studium przypadku szkoły włączającej w Szwecji pokazuje, że uczniowie pracują w grupach przez połowę czasu lekcji, a na frontalne nauczanie kadra nauczycielska wykorzystuje tylko $15 \%$ czasu (Nilholm, Alm 2010). Autorzy sugerują, że może być to związane z tradycją szkolnictwa szwedzkiego, a nie tylko z włączaniem uczniów z niepełnosprawnością. Trzeba w tym miejscu zauważyć, że dominujące praktyki nauczania w polskich szkołach są mniej sprzyjające kształceniu włączającemu.

Koncepcja edukacji włączającej jako szkoły dla wszystkich ma, jak się wydaje, dwa źródła. Po pierwsze, jest ona wynikiem gromadzenia 
coraz większej liczby dowodów, które potwierdzają, że poprawa dostępu do szkoły ogólnodostępnej oraz osiągnięć uczniów z niepełnosprawnością tylko przez działania skierowane do tej grupy, a zatem przez zapewnianie im specjalno-pedagogicznego wsparcia, ma ograniczoną skuteczność. Po drugie, neoliberalna filozofia edukacji, która zdominowała politykę edukacyjną w wielu krajach począwszy od lat 90 . XX w. okazała się destrukcyjna dla edukacji. Nie pozwala ona pełnić publicznemu systemowi szkolnemu jego podstawowych funkcji i nie idzie w parze z przemianami społecznymi. Edukacja włączająca w swoim najszerszym i najnowszym ujęciu, czyli szkoła dla wszystkich, jest propozycją konstruktywnej odpowiedzi na te dwa problemy. Zakłada ona, że współczesne systemy szkolne wymagają głębokiej przemiany w sferze wartości. Jej podstawą musi być rekonstrukcja kultury, polityki i praktyki edukacyjnej, aby placówka edukacyjna mogła skutecznie odpowiadać na różnorodność uczniów w lokalnych społecznościach, budować wspólnotę oraz zapewniać uczestnictwo i osiągnięcia wszystkim uczniom narażonym na wykluczenie (Ainscow, Booth, Dyson 2006). Powodem wykluczenia ze szkoły lub jej programu może być nie tylko niepełnosprawność, ale także bieda, specyficzna kultura, afirmująca idee niezgodne z wartościami klasy średniej, wyznawana religia, przynależność narodowościowa, język i wiele innych czynników (Ainscow, Booth, Dyson 2006; Chrzanowska 2015). Wartościami propagowanymi przez szkołę włączającą są nie tylko osiągnięcia edukacyjne, lecz również dobre samopoczucie uczniów, właściwe relacje między uczniami oraz między nimi a nauczycielami, ponadto silne więzi szkoły ze społecznością lokalną. Celem zatem jest zrównoważona edukacja, odpowiadająca indywidualnym potrzebom i wspierająca budowanie wspólnoty.

Badacze zajmujący się edukacją mają świadomość, że tworzenie szkoły włączającej w takim rozumieniu jest niekończącym się procesem rozwoju i doskonalenia całego systemu. W upowszechnianiu wartości włączających istotne są przepisy prawne i podejście polityków do tego tematu oraz przywództwo dyrektorów szkół (Erten, Savage 2012). Ci ostatni muszą być nie tylko liderami zmian, ale także facylitatorami współpracy nauczycieli, pedagogów specjalnych, psychologów i całego personelu placówki edukacyjnej. Wielu badaczy twierdzi, że konieczne jest przełamywanie barier we wspólnym rozwiązywaniu problemów przez specjalistów o różnym wykształceniu. Niektóre ba- 
dania wykazują, że nauczyciele przedmiotowi mają niewystarczające umiejętności w zakresie współpracy $z$ innymi specjalistami na rzecz wszechstronnego wspierania uczniów. Z kolei pedagodzy specjalni często postrzegają swoją dziedzinę jako wydzieloną aktywność, nie zaś jako integralną część szkolnej edukacji (Blecker, Boakes 2010). Ponadto wielu nauczycielom brakuje kompetencji w zakresie kształcenia grup zróżnicowanych pod względem kulturowym, narodowościowym i religijnym, a są to czynniki, które przyczyniają się do wykluczenia wielu uczniów (Chrzanowska 2015).

Główny wniosek płynący z przedstawionych $w$ tym rozdziale analiz sprowadza się do konstatacji, że edukacja włączająca w preskryptywnym rozumieniu jest bez wątpienia innowacyjnym modelem szkoły powszechnej. Zapewnienie uczniom z niepełnosprawnością dostępu do wysokiej jakości kształcenia w placówce tego rodzaju znajduje się w centrum koncepcji edukacji włączającej. Jednak droga do osiągnięcia tego celu wiedzie przez zbudowanie szkoły nowego typu. 



\title{
1.2. Rozwój edukacji włączającej w Europie: strategie mające na celu podnoszenie osiągnięć wszystkich uczących się
}

\author{
Anthoula Kefallinou, Verity Donnelly
}

Rozwój skuteczniejszych systemów edukacji włączającej jest coraz częściej traktowany jako konieczność, ale także jako wyzwanie dla wszystkich krajów europejskich. Niniejszy tekst opiera się na wynikach realizacji projektu, który miał na celu przedstawienie przykładów polityki i praktyk włączających skoncentrowanych na zwiększaniu osiągnięć wszystkich osób uczących się. W rozdziale przedstawiono definicje włączenia i osiągnięć wykorzystywane w tym przedsięwzięciu. Można tu również znaleźć informacje na temat systemowych reform realizowanych w poszczególnych państwach - opisano skuteczne strategie i wskazano przykłady działań społeczności lokalnych i szkół. Na koniec wymieniono ważne czynniki mające wpływ na budowanie związków między polityką włączania, badaniami naukowymi i praktyką w celu podnoszenia osiągnięć wszystkich uczących się.

\section{Słowa kluczowe:}

\section{edukacja włączająca}

\section{zwiększanie osiągnięć}




\title{
1.2. Development of inclusive education in Europe: strategies to improve the achievement of all learners
}

\author{
Anthoula Kefallinou, Verity Donnelly
}

Developing more inclusive education systems is increasingly seen as an imperative, but also as a challenge across European countries. This chapter draws on the findings of a recent European project to provide examples of inclusive policy and practice that aim to raise the achievement of all learners. Firstly, the paper considers the project's understandings of inclusion and achievement. Next, it presents evidence associated with current systemic reforms that occur at national level - it then identifies effective strategies and examples of practice at the local community level and school level. Finally, it concludes with some important considerations for building bridges between inclusive policy, research and practice to raise the achievement of all learners. 
W rozdziale omówiono zagadnienia dotyczące rozwoju skuteczniejszych systemów edukacji włączającej w Europie. Zbadano zwłaszcza rozwój polityki i praktyk sprzyjających włączeniu, których zadaniem jest podniesienie poziomu osiągnięć wszystkich uczących się. Kwestie poruszone w niniejszym tekście dotyczą:

$\rightarrow$ strategii reformowania krajowych systemów oświaty w państwach europejskich, umożliwiających upowszechnianie edukacji włączającej,

$\rightarrow$ przykładów praktyk włączających (opartych na dowodach) na poziomie społeczności i szkoły, które mają na celu zwiększenie poziomu osiągnięć wszystkich uczniów.

Tekst opiera się na najnowszych pracach Europejskiej Agencji ds. Specjalnych Potrzeb i Edukacji Włączającej (European Agency for Special Needs and Inclusive Education, dalej: Europejska Agencja), szczególnie zaś na wynikach projektu "Podnoszenie osiągnięć wszystkich uczniów w edukacji włączającej” („Raising the Achievement of all Learners in Inclusive Education")', realizowanego w latach 2014-2017.

Projekt koncentrował się na zbliżeniu różnych perspektyw naukowców i praktyków z 29 krajów europejskich. W jego trakcie zbadano, w jaki sposób strategie edukacyjne, przywództwo i rozwiązania organizacyjne mogłyby zostać wykorzystane do poprawienia osiągnięć wszystkich uczniów w środowiskach włączających. Przedsięwzięcie opierało się na ścisłej współpracy z trzema społecznościami uczącymi się:

$\rightarrow$ Istituto Tecnico Agrario Sereni (ITA Sereni, szkoła średnia drugiego stopnia) i Istituto Comprensivo Antonio Rosmini (IC Rosmini, szkoła podstawowa i średnia pierwszego stopnia) w Rzymie (Włochy),

$\rightarrow$ Zespołem Szkół w Łajskach (szkoła podstawowa i gimnazjum), gmina Wieliszew (Polska),

$\rightarrow$ Calderglen Learning Community (szkoła średnia Calderglen High School i szkoła specjalna Sanderson High Special School), East Kilbride (Szkocja).

W trakcie projektu przeanalizowano działalność tych trzech placówek, by przetestować pomysły i umożliwić wymianę doświadczeń 
między nimi. Powstała również międzynarodowa społeczność uczącą się, w ramach której toczył się dialog z kadrą kierowniczą szkół i naukowcami z 29 krajów (spotkania osobiste, forum online).

W przedsięwzięciu użyto terminu "społeczność ucząca się" w znaczeniu: „zainteresowane strony w dziedzinie edukacji z udziałem klastrów szkół, w których uczestniczą ich pracownicy i społeczność lokalna, a także naukowcy, lokalni liderzy i osoby odpowiedzialne za podejmowanie decyzji" (Europejska Agencja 2016, s. 44).

W projekcie wykorzystano również szeroką definicję podnoszenia osiągnięć, która „obejmuje wszystkie formy osiągnięć osobistych, społecznych i akademickich, które będą istotne dla poszczególnych osób uczących się w perspektywie krótkoterminowej, przy jednoczesnym zwiększeniu ich szans życiowych w perspektywie długoterminowej" (Europejska Agencja 2015, s. 2).

Edukacja włączająca była postrzegana jako „zasada organizacyjna, która leży u podstaw pracy szkoły nad równością, zapewniającą wszystkim uczniom możliwość uczenia się i odkrywania swoich mocnych stron i talentów" (Europejska Agencja 2018a, s. 44). Uznano, że bazowanie na prawach człowieka wymaga zmiany kultury i nowego podejścia pedagogicznego. Zamiast koncentrować się na indywidualnym wsparciu (tj. opartym na diagnozach medycznych), systemy oświatowe powinny zwiększać możliwości szkół w zakresie zaspokajania różnorodnych potrzeb wszystkich uczniów. Wymaga to zmiany postaw i wartości u wszystkich zainteresowanych stron w celu wspierania transformacji placówek edukacyjnych w taki sposób, aby mogły one zaspokajać potrzeby uczniów, a nie próbowały „dopasować ich" do istniejących zasad. Kierując się tym przesłaniem, projekt nie koncentrował się na grupach (lub kategoriach) wychowanków, a jego celem było przyjęcie stanowiska, zgodnie z którym docenia się i słucha się wszystkich uczniów w równym stopniu, zapewniając im realne szanse na sukces.

\section{Modele polityki sprzyjającej włączeniu w całej Europie}

Kraje uczestniczące w projekcie stosowały różne rozwiązania w celu podnoszenia osiągnięć. Dyskusja w dalszej części rozdziału przedstawia niektóre z nich, zidentyfikowane jako „dźwignie zmian”. Przykłady z poszczególnych krajów mogą być wskazówką dla autorów bieżących reform krajowych i regionalnych. 


\section{Upowszechnianie praktyki sprzyjającej włączeniu} jako strategii mającej na celu poprawienie osiągnięć

Zobowiązanie do kierowania się sprawiedliwością społeczną i stosowania edukacji bazującej na prawach człowieka wymaga szerszej polityki oświatowej, uwzględniającej zasady włączania. W Europie jednak nadal dominuje wąskie spojrzenie na tę dziedzinę, polegające przede wszystkim na umieszczaniu uczniów ze specjalnymi potrzebami edukacyjnymi i (lub) z niepełnosprawnościami w klasach ogólnodostępnych (Europejska Agencja 2018a). Wyniki projektu wskazują, że pojawiają się istotne zmiany w polityce. Niektóre kraje dążą do zwiększenia osiągnięć, poprzez promowanie na większą skalę praktyki włączania.

Jedną z zasad polityki jest umieszczenie uczniów szkół specjalnych w szkołach ogólnodostępnych i dostarczenie odpowiednich zasobów w celu poprawienia ich osiągnięć. Takie podejście zastosowano w szwedzkiej gminie Essunga, która zwróciła uwagę wielu osób, także na arenie międzynarodowej (Allan, Persson 2015; Europejska Agencja 2013). W ramach projektu „Organisation of Provision to Support Inclusive Education (2011-2014)"2 Agencja postanowiła zbadać w tej gminie możliwość organizacji skutecznego wsparcia w środowiskach sprzyjających włączeniu. Trzy szkoły podstawowe i jedna średnia przeszły trzyletni proces transformacji. W latach 2006-2007 około $20 \%$ uczących się w klasach VI-IX umieszczono w specjalnych grupach edukacyjnych i wyodrębnionych jednostkach wsparcia. W 2007 r. wszyscy uczniowie wrócili do swoich klas. Dzięki zamknięciu oddziałów kształcenia specjalnego i redystrybucji zasobów szkoły były w stanie włączyć wszystkich uczniów. Placówki osiągnęły nowe, ambitne cele, a ich uczniowie poprawili się w nauce, co potwierdziło, że taki sposób pracy jest zrównoważony. Ich pracownicy przekonali się, że orientacja na włączanie jest niezbędna by podnieść wyniki (Europejska Agencja 2013).

Inną strategią jest reorganizowanie szkół specjalnych i innych placówek specjalistycznych w celu wspierania włączania. Prowadzenie odrębnych oddziałów lub klas dla uczniów ze specjalnymi potrzebami może ograniczyć ich oczekiwania i możliwości, zmniejszyć dostęp do wiedzy specjalistycznej i zasobów ludzkich (Europejska Agencja 
2018b) oraz ograniczyć interakcje społeczne z rówieśnikami (Europejska Agencja 2018c). W związku z tymi obawami niektóre państwa przeprowadziły reorganizację szkół, zmieniając rolę specjalistycznych ośrodków wsparcia i ośrodków konsultacyjnych. Zapewniono bliższą współpracę szkół ogólnodostępnych i specjalnych lub przekształcono placówki specjalne w centra zasobów, przechodząc od etapu oddzielnej edukacji do współpracy partnerskiej tych instytucji w celu zapewnienia wysokiej jakości kształcenia wszystkim uczniom. Jest to widoczne na przykładzie Litwy, gdzie dąży się do przekształcenia szkół specjalnych w wielofunkcyjne centra oferujące dodatkowe usługi (np. społeczne, dla społeczności lokalnej, publiczne, wirtualne), aby spełnić oczekiwania społeczności lokalnych (Europejska Agencja 2018a).

Inne kraje koncentrują się szczególnie na rozwiązywaniu problemu nierównego dostępu do edukacji oraz podnoszeniu osiągnięć i szans życiowych dzięki włączeniu. Powszechnym problemem w poszczególnych państwach jest to, że szkołom osiągającym słabe wyniki i znajdującym się w niekorzystnej sytuacji często brakuje zasobów, zdolności wewnętrznych lub odpowiedniego wsparcia (OECD 2012), aby mogły zaoferować uczniom znajdującym się w najtrudniejszej sytuacji edukację wysokiej jakości. Chcąc sprostać tym wyzwaniom, niektóre kraje przekazują władzom lokalnym lub gminom dodatkowe fundusze na wsparcie szkół na obszarach defaworyzowanych albo placówek, których uczniowie notują słabsze wyniki w nauce. W Portugalii zainicjowano program „Priorytetowa interwencja w obszarze edukacji". Został on uruchomiony w 137 grupach szkół z terenów defaworyzowanych społecznie i ekonomicznie. Jego celem było zapobieganie zjawisku przedwczesnego kończenia nauki, ograniczenie liczby nieobecności w szkole, zwiększenie dyscypliny i dążenie do sukcesu edukacyjnego wszystkich uczniów. Klaster pięciu szkół położonych w pobliżu Lizbony, w regionie, w którym wiele rodzin ma poważne trudności finansowe, propaguje edukację włączającą i koncentruje się na rozwoju kompetencji kluczowych. W ramach programu stosuje się wiele strategii, w tym: ukierunkowane interwencje w zakresie poszczególnych przedmiotów, zajęcia mające na celu zapobieganie drugoroczności, rady pedagogiczne nauczycieli oraz rozmowy z uczniami i interwencje w przypadku tych, którzy się źle zachowują lub mogą zakłócać spokój (Europejska Agencja 2018a). 


\section{Opracowanie szerszych podstaw programowych}

Wiele krajów skoncentrowanych na podnoszeniu osiągnięć zmienia programy nauczania i skupia się na rozwijaniu podstawowych kompetencji, zamiast na realizacji treści przedmiotowych. Nową podstawę programową, gwarantującą bogatą i zróżnicowaną ofertę doświadczeń dla wszystkich uczących się, przyjęto w Walii. Zawiera ona takie zagadnienia, jak: sztuki ekspresyjne, zdrowie i dobre samopoczucie, nauki humanistyczne, języki obce, doskonalenie kompetencji komunikacyjnych, matematyka i umiejętność liczenia, nauki ścisłe i technologia oraz ścieżki interdyscyplinarne - umiejętność czytania i pisania, liczenia czy kompetencje informatyczne. Sieć szkół pionierskich w Walii współpracuje z organizacjami partnerskimi, które zapewniają wzbogacające program zajęcia dla uczniów, pomagające im w zdobywaniu nowych doświadczeń w dziedzinie sztuki, nauki, sportu, kultury i walijskiego dziedzictwa, a także ułatwiające im dalszą naukę i pracę (Europejska Agencja 2018b).

W innych państwach uznano, że kluczowe znaczenie dla poprawy perspektyw życiowych uczących się jest wzmacnianie ich inteligencji emocjonalnej i umiejętności społecznych. Biorąc pod uwagę fakt, że kwestie zdrowia psychicznego są coraz bardziej istotne w Europie (WHO 2015), poszczególne kraje skupiają się również na edukacji w tym zakresie, by zapobiegać problemom i rozwiązywać je dzięki lepszemu wsparciu szkół. Przykładem może być Finlandia, gdzie wprowadzona reforma systemu opieki społecznej wymaga, aby pracownicy szkół i placówek oświatowych działali wspólnie na rzecz holistycznej edukacji i dobrostanu uczniów.

\section{Poprawa monitorowania, ewaluacji i oceny}

Dane z projektu „Podnoszenie osiągnięć..." wskazują, że kraje europejskie zaczynają reagować na wyzwanie związane z koniecznością stosowania zrównoważonego podejścia do procesu ewaluacji i oceny, przewidującego mierzenie innych aspektów systemu niż tylko osiągnięcia akademickie. Niektóre państwa wraz z danymi dotyczącymi podstawowych przedmiotów i kwalifikacji gromadzą szersze informacje - na przykład w Danii wymaga się, aby szkoły przedstawiały coroczne raporty o dobrostanie uczniów, co zostało przewidziane w reformie szkół Folkeskole (Europejska Agencja 2018a).

Kolejny przykład zrównoważonego podejścia do ewaluacji oraz do oceny pochodzi z Holandii i stanowi część polityki „pracy zorientowanej 
na wyniki". Ma ona na celu podnoszenie osiągnięć wszystkich uczących się dzięki pracy ukierunkowanej na ambitne cele edukacyjne. Nauczyciele szkół podstawowych i średnich muszą stosować bieżące oceny formatywne i centralne (podsumowujące) w celu usprawnienia działań skoncentrowanych na wynikach.

\section{Realizacja polityki w praktyce}

Oprócz rozwoju polityki krajowej, projekt „Podnoszenie osiągnięć...” koncentrował się na konkretnych strukturach i procesach zachodzących w szkole, gminie i regionie, aby zapewnić równe wsparcie wszystkim uczącym się. W dalszej części rozdziału przedstawiono konkretne przykłady tego, w jaki sposób można zorganizować poszczególne obszary edukacji włączającej, aby jej uczestnicy mogli osiągać sukces. Omówiono tu konkretne przykłady z trzech społeczności uczących się (z Włoch, Polski i ze Szkocji), a także z innych krajów europejskich uczestniczących w projekcie.

\section{Ulepszenie przywództwa i podniesienie poziomu pedagogicznego $\mathrm{w}$ szkole}

\section{Strategie przywództwa}

Społeczności uczące się uczestniczące w projekcie dysponują silną kadrą kierowniczą, która ma jasną wizję edukacji włączającej. Obejmuje ona wartości i zasady, które z biegiem czasu wpłynęły na przekonania i postawy personelu placówek, oraz zainspirowały go do przyjęcia odpowiedzialności za wszystkich. Przykładem jest społeczność ucząca się w Łajskach, która działa na rzecz: zwiększenia poczucia przynależności do szkoły, systemu postaw i wartości związanych z edukacją włączającą, stałego rozwoju nauczycieli, asystentów i specjalistów, codziennej współpracy, dzielenia się wiedzą i doświadczeniem, oraz praktyki skoncentrowanej na uczących się. Wyniki pokazują, że konsekwentna realizacja wartości jest korzystna dla całej społeczności szkolnej, zwłaszcza dla nowych jej członków (Europejska Agencja 2018b).

Kierownictwo szkół biorących udział w projekcie „Podnoszenie osiągnięć..." w podejmowanie decyzji zaangażowało nauczycieli, uczniów i rodziców, budując w nich poczucie odpowiedzialności za proces edukacyjny. Podejście to, znane również jako „przywództwo rozproszone", wykracza poza tradycyjnie pojmowaną strukturę hierarchiczną 
(Europejska Agencja 2016). W tym wypadku rola kierownicza przypada także nauczycielom liderom (Liasidou, Svensson 2014), a także innym pracownikom instytucji. Jak zauważa Europejska Agencja (2018d, s. 13), „przywództwo w tym sensie nie przynależy do jednostek, ale jest nieodłącznym elementem interakcji i praktyk w kontekście szkolnym". Tego rodzaju podejście widać na przykład w maltańskiej podstawie programowej, w której lansuje się kulturę współpracy i rozproszone formy przywództwa (Europejska Agencja 2018d).

Zwiększenie interakcji i kompetencji nauczycieli było kluczowym czynnikiem w rozwoju szkoły średniej w Telemark w Norwegii. Tradycyjną placówkę specjalną, notującą kiepskie rezultaty nauczania, przekształcono w innowacyjną i integracyjną instytucję, która może pochwalić się dobrymi wynikami. Rozwojem kierowali liderzy, tworzący wspólnie wizję szkoły i budujący silną kulturę współpracy w jej otoczeniu oraz na wszystkich etapach nauczania. Proces edukacyjny nie opierał się na wykorzystaniu podręczników, lecz na materiałach dydaktycznych tworzonych przez zespół nauczycieli na podstawie programu nauczania i współdziałania na rzecz wspierania innowacji.

Kierownictwo szkoły w Telemark może polegać nie tylko na pomocy współpracowników, ale także na innych dyrektorach szkół zrzeszonych w sieciach lokalnych - w ramach zespołów przywództwa w edukacji.

W publicznej szkole podstawowej Oddeyrarskóli na północy Islandii zespoły tego rodzaju wspierają się nawzajem i wspólnie ponoszą odpowiedzialność za doskonalenie szkoły. Wszyscy liderzy ze szkół w regionie spotykają się raz w miesiącu, aby wspólnie uczyć się i budować silną, profesjonalną wspólnotę edukacyjną. Władze gminne z tamtego obszaru zawarły umowę z uniwersytetem $w$ sprawie realizacji regionalnych programów doskonalenia zawodowego nauczycieli. Liderzy wspierają rozwój nauczycieli podczas regularnych spotkań, w ramach pracy zespołowej i wspólnej nauki. Uwzględniają oni wyniki ewaluacji prowadzonej przez uczniów i rodziców oraz wykorzystują media społecznościowe do wymiany pomysłów i dobrych praktyk.

Analizując wszystkie aspekty praktyki szkolnej, kadra kierownicza może też wykorzystać samoocenę. Podczas cyklicznych spotkań do stosowania tego procesu (we współpracy z kolegami i koleżankami) zachęcano kierownictwo szkół i nauczycieli uczestniczących w projekcie (Europejska Agencja 2017a). Liderzy biorących w nim udział trzech społeczności uczących się korzystali również z rocznych planów włą- 
czenia w ramach programów doskonalenia szkół. Na poziomie lokalnym plany te powinny obejmować szeroki zakres praktyk włączania, wprowadzany w zrównoważony sposób (Europejska Agencja [w druku]). Proces samooceny można uzupełniać informacjami uzyskiwanymi od różnych zainteresowanych stron, tj. nauczycieli, uczniów oraz rodziców i opiekunów. Samoocena może stanowić "podstawę wspólnej, krytycznej refleksji na temat praktyki i przyczynić się do realizacji ambitnych planów poprawy, prowadząc do usprawnień w szkołach i w systemie" (Europejska Agencja 2017a, s. 5).

\section{Podejścia pedagogiczne}

W wielu częściach Europy nadal dominują silne tradycje „edukacji specjalnej”, koncentrującej się na formach zaspokajania i kompensacji indywidualnych potrzeb (Europejska Agencja 2013). Żeby jednak poprawić osiągnięcia uczniów, szkoły powinny skupić się na wysokiej jakości nauczania dla wszystkich (Europejska Agencja 2016). W projekcie "Podnoszenie osiągnięć..." zauważono, że pedagogika włączająca pozwala przezwyciężyć różnice między uczniami dzięki rozszerzeniu możliwości dostępnych dla wszystkich, a nie przez różnicowanie działań skierowanych tylko do niektórych (Spratt, Florian 2014). Celem tej metody jest odejście od praktyk polegających na porównywaniu, klasyfikowaniu lub etykietowaniu oraz od utrwalonego przekonania na temat stałego poziomu zdolności (Swann i in. 2012).

W ramach projektu nauczyciele zidentyfikowali bariery w procesie uczenia się i wypróbowali wiele zindywidualizowanych rozwiązań opartych na dowodach, aby je zneutralizować. Przykładem jest szkoła Romuvos w Szawlach na Litwie, w której treści edukacyjne są dostosowywane do doświadczeń, motywacji, zainteresowań, celów i stylów uczenia się dzieci. Uczniowie w klasach V-VIII mogą wybrać przedmioty i moduły, sami wypełniają też formularze samooceny i postępów w nauce. Prowadzą osobiste teczki, w których znajdują się dokumenty dotyczące postępów w zakresie ogólnych kompetencji i aktywności obywatelskiej oraz plany edukacji zawodowej.

Dowody uzyskane w projekcie „Podnoszenie osiągnięć..." pokazały również, że współpraca z nauczycielami oraz specjalistami w szkole (a także poza nią) może wpłynąć na poszerzenie wiedzy i umiejętności, co ułatwi pracę ze wszystkimi uczniami (także tymi z niepełnosprawnościami i z trudnościami w nauce). Przykładem może być 
szkoła podstawowa Valmiera (Łotwa), w której działa grupa wsparcia personelu złożona $z$ logopedy, pedagoga szkolnego, psychologa i zastępcy dyrektora. Klasy z jednego rocznika są umieszczone obok siebie, ułatwiając nauczycielom współpracę. W proces dydaktyczny zaangażowani są również rodzice. Specjalistyczne wsparcie zapewnia regionalne centrum edukacji włączającej, działające na terenie szkoły. Osiągnięcia edukacyjne, w tym wyniki akademickie uczniów, pokazują, że tego rodzaju inwestycje są opłacalne.

W projekcie zwrócono również uwagę na potrzebę zaangażowania wszystkich uczniów zarówno w widoczne, jak i „ukryte" aspekty programu nauczania. Społeczności uczące się podjęły starania mające na celu opracowanie rozwiązań, które mogą to ułatwić. Szkoła Calderglen (Szkocja) stosuje program elastyczny, zawierający ofertę kursów mistrzowskich i szkoleń prowadzących do uzyskania krajowych kwalifikacji. Program oferuje wiele praktycznych oraz zawodowych możliwości edukacyjnych, zaspokajających róznorodne potrzeby i zainteresowania uczniów (m.in. zajęcia dotyczące malowania i dekorowania, urządzeń elektronicznych, projektowania ubrań, mediów). Dzięki temu uczniowie są bardziej zmotywowani do pracy, częściej uczestniczą w lekcjach, mają ułatwiony wybór przyszłego zawodu, podnoszą swoje oceny z innych przedmiotów i uzyskują kwalifikacje potrzebne do kontynuowania nauki.

Podobne podejście zastosowano we Włoszech (ITA Sereni), gdzie nauka powiązana jest z pracą. Dzięki bezpośrednim, praktycznym doświadczeniom, zdobytym zarówno w szkole, jak i w firmach zewnętrznych, młodzi ludzie skuteczniej rozwijają swoje umiejętności i kompetencje zawodowe. Zaangażowanie rodziców w działania szkoły przyczynia się do wzrostu ich oczekiwań wobec edukacji (co jest szczególnie ważne w przypadku rodziców dzieci z niepełnosprawnościami).

Projekt „Podnoszenie osiągnięć..." podkreśla duże znaczenie opinii uczniów w procesie edukacyjnym (Europejska Agencja 2016). Uwzględnianie ich perspektywy w praktyce edukacyjnej musi być kluczowym elementem rozwoju placówki oświatowej. Dobrym przykładem jest szkoła w Hals (Dania), w której systematycznie odbywają się rozmowy nauczycieli z uczniami na temat procesu dydaktycznego, wspomagające postępy w nauce, poprawiające poziom włączenia i zapewniające dobre samopoczucie dzieci. Celem tych dyskusji (grupowych lub indy- 
widualnych) jest wzrost świadomości uczniów i opracowanie przez nich własnych ścieżek rozwoju społecznego oraz akademickiego.

\section{Rozwijanie profesjonalnych społeczności uczących się poza szkołą}

Od początku projektu biorące w nim udział instytucje edukacyjne potwierdzały chęć działania w lokalnej społeczności. Wcześniej współpracowały z różnymi partnerami w swoim otoczeniu, począwszy od przedsiębiorstw, a skończywszy na uniwersytetach. W trakcie realizacji przedsięwzięcia zwiększyła się liczba tych kontaktów i aktywność w regionie. Partnerzy społeczni (np. pracodawcy) mogą korzystać z relacji ze szkołami, kształcąc własnych pracowników i wpływając na edukację potencjalnych kandydatów do pracy. Współdziałanie może również skutkować wprowadzeniem kultury włączania i praktyk mających wpływ na szerszą społeczność (Gross i in. 2015).

Praca z nauczycielami i profesjonalistami spoza szkoły poszerza wiedzę oraz umiejętności kadry placówki, dostarczając jej narzędzia, dzięki którym możliwe jest zaspokajanie potrzeb wszystkich uczących się. W ramach projektu „Podnoszenie osiągnięć..." zebrano przykłady programów współpracy w zakresie kształcenia zawodowego. W Belgii (Wspólnota Flamandzka) trzy instytucje utworzyły zespół profesjonalnych trenerów, działających na rzecz rozwijania szkół włączających. Odbywało się to w ścisłej współpracy ze wszystkimi partnerami lokalnymi (tj. rodzicami, uczniami, poradniami, instytucjami doradztwa pedagogicznego, nauczycielami edukacji specjalnej i ekspertami z innych dziedzin). W latach 2015-2017 w sesjach coachingowych z zespołem liczącym od pięciu do dziesięciu różnych specjalistów (w zależności od konkretnych potrzeb), wzięło udział 60 szkół. Wymiana doświadczeń zawodowych w ramach sieci utworzonej przez placówki edukacyjne dotyczyła: pracy zespołowej, coachingu, badań i rozwoju szkoły w celu opracowania bardziej włączającej polityki szkolnej, usuwania barier i inwestowania w zasoby, tworzenia dobrych warunków i efektywnego przywództwa.

Inne badania poświęcone społecznościom uczącym się wskazują, że bliskie kontakty z podmiotami zewnętrznymi lub lokalnymi szkołami mogą się przyczynić do osobistego rozwoju uczniów i zwiększenia ich osiągnięć. Polska szkoła biorąca udział w projekcie przygotowuje uczniów do życia po ukończeniu nauki, świadcząc usługi doradcze i mentorskie. Intensywnie pracuje też nad ułatwieniem przejścia między 
poszczególnymi poziomami edukacji, zapewniając: warsztaty z doradcą zawodowym w szkole podstawowej, wsparcie w ostatniej klasie gimnazjum, wizyty w lokalnych szkołach ponadgimnazjalnych i wyjazdy na targi edukacyjne w Warszawie. Placówka monitoruje także wybory edukacyjne absolwentów, utrzymuje z nimi kontakt oraz współpracuje z innymi szkołami, by ułatwić uczniom płynne przejście do nowego środowiska i adaptację w nim.

Projekt „Podnoszenie osiągnięć..." potwierdza, że wzmocnienie relacji szkół z rodzinami jest niezbędnym elementem poprawiania osiągnięć uczniów. Wzajemne zaufanie i współpracę partnerską można wypracować jedynie wtedy, gdy utrzymywane są częste kontakty obu stron, a szkoła prowadzi uczciwe rozmowy z rodzicami (opiekunami). Społeczności uczące się działające w projekcie zwiększyły zaangażowanie rodziców w życie szkoły, co pozytywnie wpłynęło na funkcjonowanie instytucji. Byli oni włączani m.in. w szkolenia personelu placówki, dzięki czemu dowiadywali się o istnieniu określonych barier w uczeniu się i sposobach ich usuwania. Stosowanie tego rodzaju praktyk zwiększa umiejętności kadry pedagogicznej, a jednocześnie wiedzę rodziców na temat aktualnych problemów szkoły.

\section{Łączenie badań i praktyki}

W ramach projektu podjęto próbę budowania pomostów między badaniami a praktyką, pokazując, w jaki sposób podmioty działające w dziedzinie edukacji mogą dzielić się wiedzą i doświadczeniami. Amanda Watkins i Verity Donnelly określają systemy edukacji włączającej mianem „ewolucyjnych”, w których rozwój polityki wpływa na badania i praktykę, a te z kolei wymuszają dalsze zmiany w polityce. Zdaniem wspomnianych autorek, powiązania między badaniami a praktyką nauczania, mające na celu lepsze wsparcie wszystkich uczniów, powinny funkcjonować $w$ ramach szerszego, wielopoziomowego systemu edukacji włączającej. Jednym z oczywistych sposobów wzajemnego dostosowania badań i praktyki szkolnej jest ciągła współpraca między szkołami a instytucjami badawczymi oraz między nauczycielami a naukowcami (Watkins, Donnelly [w druku]).

Współdziałanie z instytucjami badawczymi (w tym zwłaszcza uniwersytetami) to istotny element poprawy działania szkół i podnoszenia osiągnięć uczniów (Europejska Agencja 2016). Dobrym przykładem jest Chorwacja, gdzie z inicjatywy Wydziału Kształcenia Nauczycieli Uniwer- 
sytetu w Zagrzebiu przeprowadzono w szkołach badania w działaniu (action research). Dotyczyły one: tworzenia środowiska wspierającego uczenie się, rozwijania indywidualnych interakcji między uczniami a nauczycielami, uelastycznienia procesu edukacyjnego i podkreślenia niezależności ucznia przy podejmowaniu decyzji oraz wdrażania elementów pedagogiki reform ${ }^{3}$ przez badania w działaniu (np. Montessori, Freinet). Dzięki temu możliwe było zwiększenie wiedzy i kompetencji nauczycieli w zakresie stosowania odpowiednich strategii nauczania oraz nabycie przez nich umiejętności reagowania na indywidualne potrzeby edukacyjne. Wzmocniła się również współpraca między nauczycielami - dzielenie się doświadczeniami i fachową wiedzą przyczyniło się do zwiększenia potencjału kadry szkolnej.

\section{Warunki podnoszenia osiągnięć}

W niniejszym rozdziale pokazano przykłady bieżącej polityki włączania i praktyk stosowanych w całej Europie w celu zwiększenia osiągnięć wszystkich uczących się. Coraz więcej państw traktuje edukację włączającą jako „podejście polityczne" lub sposób pracy ukierunkowany na sukces ucznia (Watkins, Donnelly [w druku]). Jak pokazują przytoczone przykłady, włączanie traktowane jest jako zasada organizacyjna i „megastrategia” (Mitchell 2014, s. 27) na rzecz podnoszenia osiągnięć. Kierunki polityki i działania praktyczne omówione w niniejszym opracowaniu należy rozpatrywać z uwzględnieniem kilku ważnych kwestii.

Po pierwsze, każdą strategię podnoszenia osiągnięć powinna wspierać całościowa polityka, która wyraźnie propaguje edukację włączającą, czyli wysoką jakość nauczania wszystkich uczniów (nie jest to jednoznaczne z umieszczeniem osób ze specjalnymi potrzebami edukacyjnymi i/lub z niepełnosprawnościami w klasach w głównym nurcie edukacji). Szkoły włączające działają lepiej, gdy zatrudniają wyspecjalizowany personel (zamiast bazowania na specjalistycznych usługach zewnętrznych, co jest praktykowane, gdy nauczycieli jest zbyt mało w stosunku do liczby uczniów), a także wtedy, gdy nie koncentrują się wyłącznie na działaniach naprawczych i kompensacyjnych (Europejska Agencja [w druku]).

Szkoły i społeczności wymagają odpowiedniego systemu wsparcia (personel pomocniczy i specjaliści oraz centra zasobów), dzięki któremu 
mogą zwiększyć zakres działania i wprowadzić rzeczywiste zmiany, włączając wszystkie zainteresowane strony w rozwijanie osiągnięć uczniów. Co najważniejsze, proces ten wymaga zmiany paradygmatu oraz postaw i wartości przez wszystkich uczestników działań oświatowych - zakwestionowania tezy, że edukacja nie jest dla każdego i że niektórzy ludzie z góry są skazani na porażkę. Jak zauważa Europejska Agencja $(2015$, s. 2) istotne jest, by "struktury i procedury operacyjne w ramach systemów edukacji włączającej opierały się na zasadach sprawiedliwości, skuteczności, efektywności i podnoszeniu osiągnięć wszystkich zainteresowanych stron".

$\mathrm{Na}$ koniec należy dodać, że chociaż dzielenie się wiedzą i wymiana praktyk okazały się korzystne podczas działań projektowych, to jednak trzeba zachować ostrożność przy podejmowaniu takich prób (Europejska Agencja 2016). Ważne jest traktowanie takiej wymiany jako procesu społecznego, a nie zwykłego przenoszenia praktyki z jednego środowiska do drugiego (tamże). Badacze twierdzą, że dzielenie się wiedzą i transfer praktyk powinny zawsze mieć na celu rozwój i poprawę sposobu, w jaki nauczyciele "myślą o swojej praktyce, oceniają ją lub dążą do jej poprawy" (Keating i in. 2005, s. 56). Dlatego pracownicy sektora oświaty w całej Europie muszą mieć to na uwadze, podejmując wysiłki na rzecz poprawy i zrównoważonego rozwoju praktyki edukacyjnej, której celem ma być zwiększenie osiągnięć wszystkich uczniów w środowiskach sprzyjających włączeniu. 



\subsection{Edukacja włączająca w badaniach naukowych \\ - perspektywa nauczyciela}

Badania naukowe pokazują, że przeważająca liczba nauczycieli w większości krajów świata ma pozytywne nastawienie do edukacji włączającej. Uznają oni prawo osób z niepełnosprawnościami i specjalnymi potrzebami edukacyjnymi do wspólnego kształcenia z rówieśnikami. Jednocześnie w wielu państwach, w tym w Polsce, uważają oni, że nie posiadają odpowiednich kwalifikacji do pracy z uczniami z niepełnosprawnością czy ze specjalnymi potrzebami edukacyjnymi, a szkoły nie są przygotowane na przyjęcie takich osób. Obawy dotyczą też innych kwestii: istniejących barier architektonicznych, dostosowania programów nauczania, relacji rówieśniczych, radzenia sobie nauczycieli ze zróżnicowanymi potrzebami i możliwościami uczniów.

\section{Słowa kluczowe:}




\subsection{Inclusive education in scientific research - teacher's perspective}

Scientific research shows that most of teachers in most of countries, have a positive attitude towards inclusive education. They recognize the right of people with disabilities and special educational needs to education with they colleagues. At the same time, in many countries, including Poland, teachers believe that they do not have enough qualifications to work with a students with disabilities or with a special educational needs, and that the schools are not prepared to receive them. Another problems are: architectural barriers, curricula, peer relations, teacher's coping with diverse needs and abilities of their pupils.

\section{Keywords:}

attitudes

teacher's qualifications

inclusive educational barriers 


\subsubsection{Postawy wobec edukacji włączającej - jakie skutki?}

Iwona Chrzanowska

Analizy wyników badań naukowych nie pozostawiają wątpliwości, że powodzenie działań włączających zależy od akceptacji tej idei przez nauczycieli (Avramidis, Kalyva 2007; Jordan, Schwartz, McGhie-Richmond 2009; Rakap, Kaczmarek 2010). Wsparcie $z$ ich strony jest wręcz niezbędne (Ross-Hill 2009).

Dokonując przeglądu literatury naukowej, głównie wyników badań nad zagadnieniem postaw nauczycieli wobec edukacji włączającej, ważne jest, by uświadomić sobie, że model ten ewoluował i nadal ewoluuje. Zmieniać się zatem może nastawienie nauczycieli, gdyż związane jest ono bardziej z chwilowym (krótszym bądź dłuższym) doświadczeniem albo uzyskaną informacją (nabytą wiedzą dotyczącą chociażby istotnych zmian oświatowych pod wpływem idei) czy wreszcie emocji z tym związanych. Postawy jednak mają bardziej trwały charakter (Murray, Morgan 1945 [za: Mika 1987]).

Początkowo w większości krajów proces włączania edukacyjnego utożsamiano z obecnością w klasie zwykłej szkoły ogólnodostępnej ucznia z zaburzeniami, z zakłóceniami w rozwoju. Ma to znaczenie dla rozpoznawania uwarunkowań kształtowania się postaw nauczycieli, zrozumienia ich nastawienia do idei włączania, a także określenia perspektywy ich zmiany w tym zakresie.

Skoncentrowanie się na uczniu ze specjalnymi potrzebami edukacyjnymi, w tym z niepełnosprawnością, skutkowała myśleniem o edukacji włączającej z punktu widzenia problemów, trudności związanych z nietypowymi trajektoriami rozwoju dziecka, obawami nauczycieli związanymi z możliwością sprostania potrzebom, ale także wymaganiom ucznia. W tym okresie okazało się, że największym wyzwaniem, 
jakie edukacja włączająca stawiała przed nauczycielem, było spojrzenie na ucznia z punktu widzenia nie tyle jego zaburzeń i trudności, ile możliwości oraz szans rozwojowych. Dość szybko również pojawiła się refleksja, że idea włączania powinna rekomendować odejście od wszelkiej kategoryzacji uczniów z uwagi na ich charakterystyki rozwojowe (Nukkarinen 2010). Obecnie coraz częściej myśląc o szkole włączającej, wskazuje się na potrzeby nie tyle konkretnej grupy, ile wszystkich uczniów. Ma być ona placówką, w której wsparcie jest naturalnym procesem uruchamianym w momencie, gdy okaże się ono niezbędne, i trwającym tak długo, jak będzie to konieczne. Różnice indywidualne łatwiej jest wówczas traktować jako zasób niż przeszkodę czy utrudnienie na drodze do osiągnięcia sukcesu w działaniach edukacyjnych (Chrzanowska 2018, s. 24).

Współczesne analizy zagadnienia pozwalają wnioskować o nastawieniach nauczycieli względem edukacji włączającej. Część z nich wskazuje na akceptację idei (Black-Hawkins, Florian, Rouse 2010; Szumski 2010, s. 159). Pojawiają się jednak i głosy przeciwne, wyrażające niepokój wobec perspektywy kształcenia wszystkich uczniów w ramach edukacji ogólnodostępnej (Forlin 2001) czy wręcz sprzeciw wobec wspólnej nauki np. z uczniami z niepełnosprawnością intelektualną (Gajdzica 2011, s. 60,77-78). Widoczne jest również swoiste warunkowanie postaw akceptujących. Nauczyciele wskazują, jakie warunki powinny, a nawet muszą być spełnione, by można było myśleć o powodzeniu działań włączających.

Wśród obserwowanych postaw, zwłaszcza tych mniej przychylnych wobec edukacji włączającej, w wynikach badań międzynarodowych powtarzają się kwestie dotyczące:

$\rightarrow$ Realnych możliwości włączenia w ramach edukacji ogólnodostępnej uczniów z niepełnosprawnością o większym stopniu lub z niektórymi rodzajami niepełnosprawności (np. intelektualnej). Wizja tzw. bezwarunkowej inkluzji w tych sytuacjach skutkuje mniej pozytywnymi postawami nauczycieli (Avramidis, Norwich 2002). Z badań Zenona Gajdzicy wynika, że $85 \%$ z nich uważa, że szkoła ogólnodostępna nie jest dobrym miejscem kształcenia dla uczniów z niepełnosprawnością intelektualną w stopniu lekkim (Gajdzica 2011, s. 60, 77-78).

$\rightarrow$ Uznawania przez nauczycieli, że praca z uczniem ujawniającym zaburzenia emocjonalne i zaburzenia zachowania jest trudniejsza, stanowi większe wyzwanie i nie umożliwia płynnego włącze- 
nia go w proces edukacji w szkole ogólnodostępnej (Avramidis, Bayliss, Burden 2000; Forlin 2001; Kniventon 2004).

$\rightarrow$ Konieczności większego zaangażowania czasowego ze strony nauczyciela w pracę z uczniem ze specjalnymi potrzebami edukacyjnymi (Paliokosta, Brandford 2010; Smith, Smith 2000; Valeo 2008) - zarówno na lekcji, jak i podczas przygotowywania się do zajęć poza godzinami dydaktycznymi. Nauczyciele postrzegają to jako dodatkowe obciążenie zawodowe.

$\rightarrow$ Konieczności korzystania z odpowiednich środków dydaktycznych (których niejednokrotnie brakuje), dostosowanych do potrzeb uczniów ze specjalnymi potrzebami (Scruggas, Mastropieri 1996).

$\rightarrow$ Zbyt dużej liczebności klas (Smith, Smith 2000), co, zdaniem nauczycieli, może uniemożliwiać efektywną indywidualizację zajęć (Scruggas, Mastropieri 1996).

$\rightarrow$ Braku wiedzy i kompetencji nauczycieli w zakresie pracy z dzieckiem ze specjalnymi potrzebami po wielu latach od wprowadzania edukacji włączającej (Westwood 2013; Gajdzica 2011; Al.-Khamisy 2004; Błeszyńska 1992; Garlej-Drzewiecka 2004; Łaś 2001; Oleńska-Pawlak 1992; Wachowiak 1992). Z tym problemem wiąże się także zagadnienie braku specjalistycznej kadry wspomagającej (Oleńska-Pawlak 1992), ponadto braku satysfakcjonujących możliwości dokształcania. Pojawiają się również obawy o zwiększenie obowiązków, którym nauczyciele będą musieli podołać w związku z pojawieniem się większej grupy uczniów ze specjalnymi potrzebami (Koutrouba, Vamvakari, Steliou 2006).

$\rightarrow$ Braku treści dotyczących włączania w programach kształcenia nauczycieli na poziomie wyższym i braku nastawienia na kształtowanie podczas studiów kompetencji do pracy w warunkach włączania (Mitchell, Hedge 2007; Bartnikowska, Wójcik 2004; Gajdzica 2001).

$\rightarrow$ Niedostosowania budynków i otoczenia do potrzeb uczniów z niepełnosprawnością (Chrzanowska 2010).

Jedną z barier edukacji włączającej, wymienionych zarówno w badaniach polskich, jak i międzynarodowych, są kompetencje nauczycieli, a właściwie przeświadczenie pedagogów, że ich nie posiadają lub uzyskali je w stopniu niewystarczającym do osiągnięcia sukcesu w pracy z uczniem ze specjalnymi potrzebami. 
Powodzenia działań związanych z edukacją włączającą nie należy jednak uzależniać - z kilku przynajmniej powodów - od kompetencji nauczycieli. Nieodparcie nasuwa się refleksja, że istotną przyczyną poczucia nieprzygotowania do pracy $z$ "innym" uczniem jest głoszona przez lata idea o koniecznej indywidualizacji kształcenia podopiecznych z tej grupy. Badacze, zarówno teoretycy, jak i praktycy związani z pedagogiką specjalną, postulowali konieczność indywidualizacji sposobu pracy z osobami z zaburzeniem (zakłóceniem) rozwoju, czyniąc z tego zasadę nadrzędną. Dosłowne traktowanie tego postulatu skutkuje naturalnym lękiem przed uczniem, którego "inność" uniemożliwia wykorzystanie w pracy jakiejkolwiek ze znanych nauczycielowi strategii postępowania. Jeśli jednak za Krzysztofem Konarzewskim (2011, s. 14) zadamy sobie pytania: „Kto jest inny?", „Od kogo?”, „Pod jakim względem?”, dochodzimy do konkluzji, że wszyscy ludzie i wszyscy uczniowie różnią się od siebie. Biorąc to pod uwagę, trzeba stwierdzić, że nauczyciele na jakimś etapie swojej pracy musieli się z „innym" uczniem zetknąć i $w$ tej sytuacji dali sobie lepiej lub gorzej radę.

Wydaje się ponadto, że argument braku kompetencji (lub ich niskiego poziomu) bywa wykorzystywany instrumentalnie jako najprostsze, a zarazem skuteczne uzasadnienie sprzeciwu wobec edukacji włączającej. Trudno zaprzeczyć, że kompetencje są podstawą skutecznej pracy w każdym zawodzie. Nikt również nie zbagatelizuje zgłaszanego problemu i nie weźmie odpowiedzialności za możliwe negatywne skutki działań niekompetentnych nauczycieli, którzy dodatkowo otwarcie o swoich brakach mówią.

Trzeba jednak pamiętać, że kompetencje zawsze można podnieść. Zawód nauczyciela, podobnie jak większość współczesnych profesji, wymaga ciągłego doskonalenia się. Idea uczenia się przez całe życie przestała być odczytywana jako przywilej bardziej świadomej części społeczeństwa, a stała się koniecznością, a wręcz obowiązkiem każdego pracownika. Wynika on z nieustannych i coraz szybszych zmian zachodzących w każdej ze sfer życia. W związku z tym wyjściowy brak kompetencji coraz rzadziej staje się istotną przeszkodą w projektowaniu i realizowaniu zmian, w tym także w edukacji. Nie uda się powstrzymać przeobrażeń szkolnictwa, wykorzystując ten argument.

Poczucie posiadania lub braku kompetencji u nauczycieli można porównać z subiektywną oceną własnego stanu zdrowia u każdego człowieka. Dwie osoby z identyczną diagnozą medyczną mogą swoją 
sytuację odczuwać zgoła odmiennie. Jedna z nich będzie twierdziła, że jest zdrowa, druga, że choruje i cierpi. Każda z nich prawdopodobnie nie mija się z prawdą, gdyż poczucie bycia zdrowym lub chorym (a także kompetentnym albo niekompetentnym) jest uwarunkowane wieloma zmiennymi.

Problematyce kompetencji i doskonalenia zawodowego nauczycieli oraz ich uwarunkowań poświęcono wiele badań. Niektóre z nich, np. TALIS (Teaching and Learning International Survey) z 2013 r., pozwalają porównać wyniki z różnych krajów. Na ich podstawie można stwierdzić m.in., że polscy nauczyciele częściej niż ich koledzy z 32 państw uczestniczą w różnych formach doskonalnia zawodowego.

Tabela 1. Uczestnictwo nauczycieli w różnych formach doskonalenia zawodowego

\begin{tabular}{l|c|c}
\multicolumn{1}{c|}{ FORMA DOSKONALENIA ZAWODOWEGO } & POLSCY NAUCZYCIELE & ŚREDNIA DLA TALIS \\
\hline kursy doskonalące & $81 \%$ & $71 \%$ \\
\hline konferencje/seminaria & $52 \%$ & $44 \%$ \\
\hline sieci współpracy & $41 \%$ & $38 \%$ \\
\hline mentoring, hospitacje, coaching & $45 \%$ & $30 \%$ \\
\hline indywidualne/wspólne badania & $38 \%$ & $31 \%$ \\
\hline szkolenia poświęcone problematyce SPE & $54 \%$ & $28 \%$ \\
\hline szkolenia poświęcone indywidualizacji pracy z uczniem z SPE & $49 \%$ & $36 \%$
\end{tabular}

Źródło: Hernik (red.) 2014, s. 23-24.

Mniej optymistyczne dla polskich nauczycieli są jednak dane dotyczące ich poczucia wsparcia w rozwoju zawodowym. Okazuje się, że ok. $40 \%$ z nich częściowo i ok. $30 \%$ w całości pokrywa koszty związane z doskonaleniem zawodowym (średnia dla badania TALIS wynosi odpowiednio: $11 \%$ i $12 \%$ oraz $5 \%$ i $9 \%$ ). Polscy nauczyciele mają również mniejszy wybór w zakresie "refundacji” ich zaangażowania w doskonalenie. Z danych wynika, że mniej popularne niż średnio $w$ badaniu TALIS jest stosowanie dodatku motywacyjnego do pensji z tytułu doskonalenia zawodowego. Zaledwie nieco ponad $5 \%$ polskich nauczycieli otrzymało taki dodatek (średnia dla TALIS - 8\%). Rzadziej również stosowane są w Polsce niefinansowe formy wsparcia, np. dni wolne, urlopy szkoleniowe 
- ok. $10 \%$ pedagogów deklaruje, że uzyskało takie wsparcie, przy średniej TALIS wynoszącej 14\% (Hernik [red.] 2014, s. 28).

Jeśli przyjrzeć się zjawisku doskonalenia zawodowego w odniesieniu do idei edukacji włączającej, to najbardziej interesujące są wskaźniki dotyczące nauczycieli ze szkół i z przedszkoli ogólnodostępnych. W założeniu to właśnie tego rodzaju placówki mają brać udział w edukacji włączającej, sieć tych instytucji jest bowiem najbardziej rozbudowana.

Z badań realizowanych w Polsce wynika, że nauczyciele z placówek ogólnodostępnych mają mniej dodatkowych kwalifikacji (uzyskanych poza kierunkowym wykształceniem) niż nauczyciele szkół integracyjnych oraz specjalnych. W tej pierwszej grupie posiadanie takich kwalifikacji deklaruje 35,8\% badanych, w drugiej-ok. 58\%, w trzeciej-niemal 80\%. Porównywalne grupy nauczycieli z każdego rodzaju szkół planują natomiast podjęcie działań w tym zakresie $(61 \%$ z ogólnodostępnych i specjalnych, $66 \%$ z integracyjnych). Dane wskazują na zróżnicowanie zasobów w postaci posiadanych dodatkowych kwalifikacji w zależności od etapu edukacyjnego, na którym pracują nauczyciele. W szkołach ogólnodostępnych najczęściej dysponują nimi nauczyciele z klas IV-VI szkół podstawowych (ok. 44\%), najrzadziej z klas VI-VIII i szkół ponadpodstawowych (28\%). Podobną tendencję możemy obserwować w planowaniu działań w tym zakresie. Inaczej sprawa wygląda wśród nauczycieli z placówek specjalnych. W tej grupie im wyższy etap kształcenia, tym większy odsetek posiada dodatkowe kwalifikacje wspierające ich kompetencje edukacyjne. W przypadku planów doskonalenia tendencja jest tu analogiczna jak w placówkach ogólnodostępnych - im wyższy etap kształcenia, tym mniejsza liczba nauczycieli zamierza podnosić swoje kwalifikacje (Chrzanowska 2019, s. 230)'.

Z punktu widzenia edukacji włączającej ciekawe są powody planowania doskonalenia zawodowego przez nauczycieli. Najczęściej wskazywali oni: chęć poprawienia swojej pozycji zawodowej, finansowej oraz zabezpieczenie się przed możliwością utraty pracy. Tylko w przypadku nauczycieli z placówek ogólnodostępnych wśród trzech integracyjnych i specjalnych z całej Polski (edukacja przedszkolna, wczesnoszkolna, klasy IV-VI oraz gimnazjum). Przeprowadzono je tuż przed wejściem w życie reformy systemu oświaty z $2017 \mathrm{r}$., Ustawa z dnia 14 grudnia 2016 r. - Prawo oświatowe (Dz.U. z 2017 r. poz. 60 ze zm.). Pełne wyniki dostępne są w publikacji I. Chrzanowskiej Nauczyciele o szansach i barierach edukacji włączajq̨cej. 
najistotniejszych przyczyn znalazła się kwestia braku umiejętności lub wiedzy (zastąpiła ona "zabezpieczenie się przed utratą pracy"). Niezależnie jednak od etapu edukacyjnego, na którym pracują nauczyciele, jest to powód wymieniany na trzecim miejscu, dodatkowo im wyższy etap kształcenia, tym mniejsza liczba nauczycieli wskazuje go jako jeden z najistotniejszych (wczesna edukacja - 33,3\%, klasy IV-VI szkoły podstawowej-20,9\% i szkoła ponadpodstawowa -19,3\%) (Chrzanowska 2019, s. 232). Wyniki badań potwierdzają istnienie niebezpiecznej tendencji związanej z poczuciem braku stabilizacji zawodowej wśród nauczycieli. Sporo wskazuje na to, że każda z wymienionych grup traktuje doskonalenie zawodowe jako zabezpieczenie przed utratą pracy lub argument w walce o wyższą pensję.

Innym zagadnieniem wartym przeanalizowania w związku z postawami wobec edukacji włączającej jest poziom satysfakcji zawodowej, zadowolenia z pracy lub - z drugiej strony - poczucia obciążenia zawodowego. Satysfakcja z wykonywanej profesji oznacza możliwość zaspokajania przez jednostkę własnych potrzeb, osiągania celów, pielęgnowania wartości i przekonań, a to jest z kolei podstawą kształtowania się postaw wobec zadań zawodowych (Bartkowiak 2009, s 119). Z badań wynika, że zadowolenie z wykonywanych obowiązków wpływa korzystnie zarówno na efekty pracy, jak i na samopoczucie pracownika (Bańka 2000; Zalewska 2009). Brak satysfakcji obniża skuteczność działania i przyczynia się do szybkiego wypalenia zawodowego (Poraj 2009, s. 274). Poczucie zadowolenia (bądź niezadowolenia) wynika z różnych czynników występujących w środowisku zawodowym. Pozytywne nazywane są motywatorami i są wśród nich: dokonania, uznanie, treść pracy, odpowiedzialność, awans, możliwości rozwoju. Do braku satysfakcji przyczyniają się tzw. czynniki higieny, do których zalicza się: relacje interpersonalne, warunki pracy, organizację, kierownictwo i wynagrodzenie (Sowińska 2014).

Jednym z istotnych źródeł satysfakcji zawodowej nauczycieli jest prestiż zawodu - im niższy, tym zadowolenie z wykonywanego zawodu się zmniejsza (Federowicz, Haman, Herczyński 2013, s. 38). Badania zrealizowane w 2016 r. ${ }^{2}$ w grupie ok. 2 tysięcy nauczycieli pracujących w placówkach ogólnodostępnych, integracyjnych i specjalnych wska- 
zują, że poczucie wysokiego prestiżu zawodu towarzyszy nielicznym osobom. Uzyskane rezultaty są bardzo niepokojące - niewielu ankietowanych z placówek ogólnodostępnych zgadza się ze stwierdzeniem "praca nauczyciela ma wysoki prestiż". Dodatkowo, na podstawie tendencji rozkładu wyników można przyjąć, że im wyższy etap edukacyjny, tym mniejsza liczba nauczycieli podpisuje się pod tym stwierdzeniem.

Tabela 2. Prestiż zawodu nauczyciela w opiniach nauczycieli z placówek ogólnodostępnych

\begin{tabular}{l|c|c}
\multirow{2}{*}{ ETAP EDUKACYJNY (PLACówKA OGóLNODOSTĘPNA) } & \multicolumn{2}{|c}{ PRACA NAUCZYCIELA MA WYSOKI PRESTIŻ } \\
\cline { 2 - 3 } & TAK & RACZEJ TAK \\
\hline przedszkole & $3,4 \%$ & $20,2 \%$ \\
\hline klasy I-III szkoły podstawowej & $1,85 \%$ & $9,25 \%$ \\
\hline klasy IV-VI szkoły podstawowej & $0,97 \%$ & $4,33 \%$ \\
\hline gimnazjum & $0 \%$ & $9,2 \%$
\end{tabular}

Źródło: I. Chrzanowska, badania własne.

Tabela 3. Prestiż zawodu nauczyciela w opiniach nauczycieli z placówek integracyjnych

\begin{tabular}{l|c|c}
\multirow{2}{*}{ ETAP EDUKACYJNY (PLACÓWKA INTEGRACYJNA) } & \multicolumn{2}{|c}{ PRACA NAUCZYCIELA MA WYSOKI PRESTIŻ } \\
\cline { 2 - 3 } & TAK & RACZEJ TAK \\
\hline przedszkole & $4,1 \%$ & $15,2 \%$ \\
\hline klasy I-III szkoły podstawowej & $2,96 \%$ & $2,44 \%$ \\
\hline klasy IV-VI szkoły podstawowej & $0 \%$ & $6,8 \%$ \\
\hline gimnazjum & $0 \%$ & $5,4 \%$
\end{tabular}

Źródło: I. Chrzanowska, badania własne.

Tabela 4. Prestiż zawodu nauczyciela w opiniach nauczycieli z placówek specjalnych

\begin{tabular}{l|c|c}
\multirow{2}{*}{\multicolumn{2}{c}{ ETAP EDUKACYJNY (PLACÓWKA SPECJALNA) }} & \multicolumn{2}{c}{ PRACA NAUCZYCIELA MA WYSOKI PRESTIŻ } \\
\cline { 2 - 3 } & TAK & RACZEJ TAK \\
\hline przedszkole & $0 \%$ & $6,5 \%$ \\
\hline klasy I-III szkoły podstawowej & $5,8 \%$ & $7,3 \%$ \\
\hline klasy IV-VI szkoły podstawowej & $4,4 \%$ & $4,4 \%$ \\
\hline gimnazjum & $2,96 \%$ & $1,94 \%$
\end{tabular}

Źródło: I. Chrzanowska, badania własne. 
Wyniki badań Iwony Chrzanowskiej wskazują, że jedynie 1,56\% nauczycieli z placówek ogólnodostępnych, 1,68\% z integracyjnych i 3,7\% ze specjalnych ma poczucie wysokiego prestiżu swojego zawodu. Jeśli się uwzględni dwie pozytywne kategorie: „tak" i „raczej tak", to odsetek ten wzrasta do odpowiednio: 12,2\%, 10,3\% i 8,6\%. Są to wskaźniki znacznie gorsze niż w innych krajach. Średnia dla 32 państw biorących udział w badaniu TALIS wynosi 31\% (wskaźnik poniżej 5\% uzyskano w Szwecji, we Francji i w Słowacji, najwyższy - 84\% - w Malezji). Odsetek nauczycieli twierdzących, że ich zawód jest doceniany przez społeczeństwo, wyniósł w tym badaniu 18\% (Piwowarski i in. 2015, s. 38).

Polscy nauczyciele czują ciężar społecznej oceny swojej profesji, zdając sobie jednocześnie sprawę z wiążących się z nią wysokich wymagań i dużej odpowiedzialności. To właśnie te czynniki okazują się najsilniejszymi obciążeniami zawodowymi, wyprzedzając inne, np. pracę w grupie zróżnicowanej czy trudności wychowawcze. Blisko połowa $(49,97 \%)$ badanych nauczycieli z placówek ogólnodostępnych wskazuje je jako czynniki silnie ich obciążające, niewiele jednak niższe są wskaźniki dotyczące trudności wychowawczych (48,6\%) i pracy w grupie zróżnicowanej $(47,2 \%)$. Warto w tym miejscu odnieść się również do wyników badań nauczycieli z placówek integracyjnych. Dla nich większym obciążeniem w pracy zawodowej są trudności wychowawcze (zgadza się z tym stwierdzeniem ok. 52\% pytanych), następnie praca w grupie zróżnicowanej $(47,4 \%)$ i społeczna ocena zawodu - 44,2\% (Chrzanowska 2019, s. 256).

Inni badacze w grupie czynników obciążających wymieniają również: przeciążenie pracą (Pyżalski 2010c, s. 31; Piwowarski i in. 2015, s. 38), brak pewności zatrudnienia (Piwowarski i in. 2015, s. 38), niskie zarobki (Fedorowicz i in. 2013, s. 39; Pyżalski 2010b, s. 53-54; Piwowarski i in. 2015, s. 38), a także: przeładowane programy i plany nauczania, współpraca z rodzicami uczniów (Pyżalski 2010b, s. 53,69) oraz z innymi nauczycielami (Pyżalski 2010a, s. 109).

$Z$ analiz wynika także, że wielu nauczycieli w Polsce żałuje wyboru zawodu - ok. $20 \%$ "raczej" lub „zdecydowanie" twierdzi, że nie wybrałoby ponownie tej profesji, 10\% żałuje, że zostało nauczycielem, a ok. 30\% kadry gimnazjum zastanawia się, czy korzystniejsza nie byłaby inna droga zawodowa (Hernik 2014, s. 39). Badania zrealizowane przez Iwonę Chrzanowską wskazują nieco niższe wartości - 7,2\% nauczycieli z placówek ogólnodostępnych, 8,1\% z integracyjnych i 17,4\% ze specjalnych nie wybrałoby tego zawodu, gdyby ponownie miało taką możliwość. 
W dużym stopniu prawdziwe będzie stwierdzenie, że obecnie polscy nauczyciele są sfrustrowani, czują się silnie obciążeni obowiązkami, które na nich spoczywają, i zaniepokojeni zmianami - zarówno znanymi, jak i oczekiwanymi. Nie jest tajemnicą, że edukacja włączająca również oznacza zmiany, jednak, jak stwierdzono wcześniej, większość nauczycieli popiera tę ideę. Ponadto, jak wynika z badań, na pytanie: „Czy edukacja włączająca jest dobrym rozwiązaniem dla uczniów ze specjalnymi potrzebami edukacyjnymi (w tym uczniów z niepełnosprawnością)?" odpowiedzi „tak" udzieliło 75\% nauczycieli z placówek ogólnodostępnych, ok. $80 \%$ z integracyjnych i 58\% ze specjalnych. $\mathrm{Na}$ to pytanie, ale dotyczące uczniów sprawnych, odpowiedzi twierdzącej udzieliło: 73\% nauczycieli z placówek ogólnodostępnych, 71,6\% z integracyjnych i 73,4\% ze specjalnych (Chrzanowska 2019, s. 119). Wydaje się, że obok akceptacji dla edukacji włączającej pojawia się wśród nauczycieli także obawa, jak będzie ona realizowana. Niepokoją się o to, że pozostaną sami z problemami, których być może jeszcze sobie nie uświadamiają, że zapanuje chaos, oddziałujący przede wszystkim na uczniów, ale pośrednio dotykający również nauczycieli. Krzysztof Konarzewski (2004) przewrotnie opisał stawiane im wymagania: „Nauczyciel ma skutecznie nauczać, ale nie stresować, wymagać, ale nie narzucać, utrzymywać dyscyplinę, ale wyrzec się przymusu, być sprawiedliwy, ale w każdym znaleźć coś dobrego, pomagać słabszym i nie zaniedbywać zdolnych. I nade wszystko ma z poświęceniem pracować - dokształcać się i doskonalić zawodowo, troszczyć się o szkolne i pozaszkolne losy każdego ucznia, działać na rzecz lokalnego środowiska, utrzymywać kontakt z nowatorską pedagogiką. Wszystko to ma robić, nie patrząc na zegarek, nie licząc pieniędzy, nie żądając lepszych warunków pracy".

Pytanie postawione w tytule niniejszego podrozdziału - „Postawy nauczycieli wobec edukacji włączającej-jakie skutki?" - było w zamierzeniu przewrotne. Większa część nauczycieli deklaruje bowiem (i nie jest to żadnym zaskoczeniem) akceptację idei edukacji włączającej. Na wysnucie tego wniosku pozwalają analizy badań, zarówno międzynarodowych, jak i polskich. Jednocześnie jednak kadra pedagogiczna coraz odważniej, a raczej - z większą determinacją - wypowiada się na temat tego, co im utrudnia realizację zadań zawodowych. Od wsłuchania się w te potrzeby, a tak naprawdę od reakcji na nie, będzie zależało powodzenie działań włączających, a także przyszłość tego zawodu. 


\subsubsection{Kompetencje zawodowe - jakie wyzwania?}

Iwona Chrzanowska, Grzegorz Szumski

W wielu krajach inicjujących zmiany w edukacji w kierunku inkluzji (włączania) jednym z istotnych zagadnień jest próba zdefiniowania, jakie kompetencje powinien posiadać nauczyciel, by mógł skutecznie pracować z dziećmi w przedszkolu i szkole ogólnodostępnej, w zróżnicowanych grupach. Rozważania dotyczące wyzwań warto podzielić na dwie części.

Pierwsza skoncentruje się na realiach i perspektywach kształcenia przyszłych nauczycieli, a także na doskonaleniu zawodowym osób już pracujących. Druga dotyczy wymagań wynikających z idei edukacji włączającej z punktu widzenia kompetencji nauczycielskich.

Wyzwaniem kompetencyjnym nauczycieli są realia kształcenia i doskonalenia zawodowego. Dane Europejskiej Agencji Rozwoju Edukacji Uczniów ze Specjalnymi Potrzebami Edukacyjnymi ${ }^{3}$ pokazują, że jednym z kluczowych wymogów wobec kandydatów na nauczycieli na całym świecie są odpowiednio wysokie wyniki końcowe na świadectwie umożliwiającym ubieganie się o kształcenie na poziomie wyższym (Europejska Agencja 2011, s. 21). Tymczasem polskie diagnozy (NIK 2017) wskazują na wyraźnie zarysowujące się zjawisko negatywnej selekcji w rekrutacji na studia, kierunki i specjalności nauczycielskie. Okazuje się, że 9,3\% osób przyjętych w roku akademickim 2014/2015 uzyskało na egzaminie maturalnym najniższe wyniki (średnio od 30 do 49 punktów, czyli minimalny poziom umożliwiający uzyskanie 
pozytywnego wyniku egzaminu) ${ }^{4}$ (NIK 2017, s. 7, 25). Jednocześnie, jak wynika z analiz, wzrastają wskaźniki dotyczące osób, które w terminie nie obroniły prac dyplomowych i magisterskich. W roku akademickim 2012/2013 dotyczyło to odpowiednio: 37\% i 47\% studentów, w 2014/2015 - 47\% i 56\% (tamże, s. 24). Na bardzo wysokim poziomie znajdują się również wskaźniki "odsiewu" w trakcie studiów. Średnio ponad jedna trzecia $(36,4 \%)$ osób na kierunkach nauczycielskich zostaje skreślona z listy studentów (tamże, s. 29). Dane te znajdują potwierdzenie w problemach sygnalizowanych przez środowisko nauczycieli akademickich, ale również przez samych studentów, którzy, jak wynika z badań Najwyższej Izby Kontroli, mówią o konieczności podwyższenia wymagań rekrutacyjnych (poprzez wprowadzenie egzaminów wstępnych, rozmów kwalifikacyjnych, testów psychologicznych, badań przydatności zawodowej). Studenci podkreślają, że wśród ich kolegów na kierunkach nauczycielskich są tacy, którzy nigdy nie powinni wykonywać tego zawodu - ze względu na brak predyspozycji, wiedzy i umiejętności.

Studenci apelują o poprawienie jakości kształcenia nauczycieli oraz o podwyższenie wymagań, by nastąpił naturalny "odsiew" i dyplom otrzymywali jedynie ci, którzy są zdeterminowani, pracowici, posiadają wiedzę i odpowiednie umiejętności. Jednocześnie dostrzegają oni również poważny problem związany z prestiżem zawodu w Polsce (NIK 2017, s. 26). Tymczasem analizy wyników badań międzynarodowych pokazują jednoznacznie, że najlepsze systemy edukacyjne na świecie opierają się nie tylko na jakości kształcenia i dbałości o pozyskanie najlepszych kandydatów do zawodu, ale także na zapewnieniu im doskonałych warunków pracy (Europejska Agencja 2011, s. 23). Przykładem jest Finlandia - kraj kształcący uczniów niezmiennie plasujących się w czołówce wyników w światowych badaniach kompetencji. Obowiązują tam wyśrubowane wymagania wstępne na studia nauczycielskie, a sam proces rekrutacyjny jest wieloetapowy. W rezultacie tylko najlepsi kandydaci mogą podjąć edukację, a chętnych wśród młodych ludzi nie brakuje. Status profesji jest bardzo wysoki, porównywalny z zawodem lekarza i prawnika (Fazlagić 2014). 
Inne wyzwanie związane z kształceniem nauczycieli zostało zdefiniowane przez UNESCO. Jest nim konieczna zmiana programów studiów dotycząca wprowadzenia do nich problematyki edukacji włączającej (UNESCO 2008). Z uwagi na różnice w systemach kształcenia zawodowego nauczycieli w różnych krajach ich porównanie jest bardzo trudne. Analiza raportów z 29 państw wskazuje, że w mniej niż 10\% $z$ nich oferowana jest specjalizacja z zakresu specyficznych potrzeb edukacyjnych na pierwszym etapie kształcenia wyższego (studia licencjackie). W większości krajów w ramach niektórych przedmiotów wprowadzane są zagadnienia związane z zaspokajaniem indywidualnych wymagań uczniów. W niektórych ograniczają się one do problematyki specjalnych potrzeb i niepełnosprawności, w innych dotyczą potrzeb w odniesieniu do wszystkich uczniów. Treści te są realizowane w postaci jednego modułu lub dwóch (przedmiotów w planie studiów), a w niektórych krajach w ramach dłuższych kursów, nierzadko obligatoryjnych. W Szwajcarii zagadnienia dotyczące szeroko rozumianej edukacji włączającej (specjalne potrzeby edukacyjne, praca w grupie zróżnicowanej itp.) stanowią $5 \%$ programu studiów dla nauczycieli szkół podstawowych i ponadpodstawowych (Europejska Agencja 2011, s. 28). Podobnie jak w Polsce, częściej treści dotyczące problematyki edukacji włączającej pojawiają się w programach edukacji wczesnoszkolnej niż na kierunkach nauczycielskich związanych z kształceniem przedmiotowym.

Rzadko na świecie (w Europie) kształcenie z zakresu edukacji włączającej odbywa się w osobnych modułach. W Niemczech dzieje się tak na połowie uczelni (w zakresie wczesnej edukacji), w Danii tematyka inkluzji omawiana jest nadal $w$ ramach programu $z$ pedagogiki specjalnej, z kolei w Hiszpanii zajęcia z zakresu edukacji włączającej sprowadzają się w zasadzie do specjalnych potrzeb edukacyjnych (Europejska Agencja 2011, s. 25-26).

W Polsce, jak wskazują analizy przeprowadzone przez Beatę Jachimczak, kształcenie w zakresie edukacji włączającej stanowi połączenie wspomnianych wcześniej rozwiązań. W ofercie $22 \%$ uczelni publicznych (4 z 18 uniwersytetów) znajduje się specjalizacja dotycząca edukacji włączającej, w większości wypadków koncentrująca się na problematyce specyficznych potrzeb edukacyjnych i niepełnosprawności uczniów. Skierowana jest do nauczycieli wczesnej edukacji (przedszkolnej, wczesnoszkolnej) (Jachimczak 2018, s. 41). Wręcz dramatycznie źle przedstawia się ta sytuacja w odniesieniu do kształcenia przedmio- 
towego (od klasy IV szkoły podstawowej i wyżej). W programach studiów nauczycielskich nie tylko nie ma treści związanych z problematyką włączania, ale również pedagogiki specjalnej czy zajęć dotyczących specjalnych potrzeb edukacyjnych. Absolwenci kończący kształcenie nauczycielskie nie mają zatem żadnej wiedzy na temat ucznia z niepełnosprawnością i ze specjalnymi potrzebami edukacyjnymi, pracy w grupie zróżnicowanej, projektowania działań wspierających, dostosowywania wymagań, organizacji kształcenia i treści.

Nauczyciele (i nie tylko oni) mogą zwiększyć kompetencje w tym zakresie w ramach doskonalenia zawodowego w trakcie studiów podyplomowych kwalifikacyjnych lub doskonalących, a także kursów i szkoleń. Kwestia ta omawiana była w poprzednim podrozdziale, warto jednak przypomnieć wynikającą z badań zależność, że im wyższy etap edukacyjny szkoły ogólnodostępnej, tym mniejsza liczba nauczycieli doskonali się zawodowo, w tym w zakresie poruszanej tu problematyki. Nie wynika to z ich ignorancji czy niechęci wobec zdobywania nowych umiejętności, a raczej z mniejszej liczby uczniów ze specjalnymi potrzebami edukacyjnymi czy z niepełnosprawnością, z którą mają szansę się spotkać. Wynika to z prostego faktu - na etapie przedszkolnym i wczesnoszkolnym uczniowie ze specjalnymi potrzebami uczestniczą w edukacji włączającej w większej liczbie, jednak zauważalnie ubywa ich wraz z przechodzeniem na kolejne poziomy. Z danych Systemu Informacji Oświatowej (SIO 2017) wynika, że o ile w szkołach ogólnodostępnych na poziomie podstawowym w roku szkolnym 2017/2018 znajdowało się ok. 63,3 tys. uczniów ze SPE, o tyle na etapie edukacji ponadpodstawowej już jedynie 28,6 tys., co oznacza, że ponad połowa z nich (55\%) nie kontynuowała nauki w szkole ogólnodostępnej po ukończeniu edukacji podstawowej. W szkołach specjalnych wielkości te wynoszą odpowiednio: 30,4 tys. i 24 tys.

W opinii osób z niepełnosprawnością barierami wpływającymi na zmianę ścieżki kształcenia są: brak akceptacji ze strony rodziców uczniów sprawnych oraz samych uczniów, niedobór specjalistów w szkołach ogólnodostępnych, zbyt liczne klasy, nieprzygotowanie uczniów przez szkołę do wejścia na rynek pracy, brak rzetelnej diagnozy, ale również nieakceptowanie niepełnosprawności dziecka w jego rodzinie, nadopiekuńczość osób bliskich (Sochańska-Kawiecka, Makowska-Belta, Milczarek, Morysińska, Zielińska 2015, s. 38-39). Niektóre z tych barier wprost, a wszystkie pośrednio, będą wyzwaniem dla nauczyciela, 
który wykorzystując swoje kompetencje, będzie musiał minimalizować niekorzystne ich skutki, umożliwiając funkcjonowanie ucznia w ramach edukacji włączającej.

Kolejne wyzwanie dotyczące kompetencji zawodowych nauczycieli w ramach edukacji włączającej to realizacja stażu zawodowego, a raczej adaptacji zawodowej i rozwoju zawodowego nauczycieli stażystów. Analizy NIK ${ }^{5}$ wskazują niepokojące fakty dotyczące polskich doświadczeń w tym zakresie, np. że blisko jedna czwarta opiekunów stażu nie ma doświadczenia lub większych osiągnięć zawodowych (przez cały okres ich pracy). Plany rozwoju zawodowego stażysty nie były ukierunkowane na przyrost konkretnych umiejętności, nie uwzględniały istotnych kompetencji niezbędnych w rozwoju zawodowym - miały przeważnie charakter ogólny, schematyczny, stanowiąc zbiór osobnych, niespójnych działań. Uniemożliwiało to monitorowanie postępów uczestnika stażu i ocenę jego dorobku zawodowego. Ponadto procedura awansu zawodowego nie była powiązana z doskonaleniem zawodowym. Więcej niż jedna czwarta planów rozwoju była identyczna, pozostałe były w znacznym stopniu podobne (NIK 2017, s. 9). Trzeba przy tym zauważyć, że dodatek finansowy za opiekę nad nauczycielem stażystą jest bardzo niski (30-150 zł, a w połowie szkół 30-75 zł) (tamże, s. 8). Procedura awansu nauczycieli w Polsce jest nieprzesiewowa. W latach 2014-2016 jedynie 0,2\% stażystów nie uzyskało wyższego stopnia zawodowego w efekcie przystąpienia do postępowania. Zbliżone były wskaźniki na kolejnych etapach awansu: 0,4\% z nauczyciela kontraktowego na mianowanego, $0,7 \%$ z mianowanego na dyplomowanego (tamże, s. 13).

Dane GUS z lat 2014-2015 wskazują, że największą grupę w kadrze edukacyjnej stanowią osoby ze stopniem nauczyciela dyplomowanego $(54,9 \%)$, następnie są nauczyciele mianowani $(23,1 \%)$, kontraktowi $(15,1 \%)$, stażyści (4\%) i bez stopnia awansu (3\%) (Oświata i wychowanie 2017, s. 118). Ponad połowa nauczycieli mogłaby zatem stanowić naturalne środowisko liderów, w tym dla edukacji włączającej, gdyby zbagatelizować wyniki kontroli NIK i nie przejmować się niepokojącymi wskaźnikami sygnalizującymi nieprawidłowości w całym procesie awansu. 
Wieloletnie niekorzystne tendencje w zakresie przygotowywania nauczycieli i ich rozwoju zawodowego mogą być bardzo ważną barierą w rozwoju edukacji włączającej na wysokim poziomie. Trzeba mieć świadomość, że efektywne jej wdrażanie jest trudne i wymaga zaangażowanej kadry pedagogicznej o dużych kompetencjach zawodowych.

W dotychczasowych badaniach na temat uwarunkowań efektywności nauczycieli w zakresie edukacji włączającej ustalono, że istnieją trzy grupy czynników o kluczowym charakterze: postawa wobec tej idei i przekonanie na temat istoty niepełnosprawności, poczucie samoskuteczności w kształceniu klas włączających oraz posiadane umiejętności metodyczno-organizacyjnych (Jordan, Schwartz, McGhie-Richmond 2009; Europejska Agencja Rozwoju Edukacji Uczniów ze Specjalnymi Potrzebami 2012). Ponieważ każdy z tych czynników podlega zmianom i daje się, przynajmniej w pewnym zakresie, formować w toku kształcenia, dokształcania i doskonalenia, powinny być one uwzględnione w programach nauczania.

Postawy nauczycieli wobec edukacji włączającej są przedmiotem licznych analiz na całym świecie (Avramidis, Norwich 2002; De Boer, Pijl, Minnaert 2011). Niestety, większość z nich wskazuje, że są one $z$ reguły neutralne lub negatywne. Spośród 26 badań szkół podstawowych objętych systematycznym przeglądem żadne nie wskazywało na to, że nauczyciele mają pozytywne postawy wobec włączania uczniów z niepełnosprawnością (De Boer i in. 2011). Podobne wyniki uzyskiwano w wielu polskich badaniach (por. Parys 2007). Istnieją jednak dowody na to, że nastawienie pedagogów wobec edukacji włączającej można poprawiać przez odpowiednie szkolenia. Przykładem może być zaledwie 28-godzinny kurs dla nauczycieli izraelskich i palestyńskich, który przyczynił się do zmiany ich postaw wobec włączania uczniów z większością rodzajów niepełnosprawności (z wyjątkiem lekkiej niepełnosprawności intelektualnej, zaburzeń zachowania i głębokich trudności w uczeniu się) (Lifshitz, Glaubman, Issawi 2004). Program szkolenia dotyczył koncepcji normalizacji i włączania, prawnych regulacji kształcenia uczniów z niepełnosprawnością w Izraelu i Autonomii Palestyńskiej, rozwoju edukacji włączającej w krajach przodujących w jej upowszechnianiu, dylematów moralnych związanych z wykluczaniem dzieci z niepełnosprawnością, zawierał również elementy metodyczne (Lifshitz i in. 2014). Wyników wskazujących na pozytywną rolę kształtowania postaw nauczycieli wobec edukacji 
włączającej dostarczają także badania z innych krajów (np. Avramidis, Kalyva 2007; Kim, Park, Snell 2005).

Czynnikiem silnie związanym z postawami nauczycieli są ich przekonania na temat istoty niepełnosprawności. Anne Jordan, Eileen Schwartz i Donna McGhie-Richmond (2009) twierdzą, że mogą mieć one charakter "patogeniczny" lub „interwencjonistyczny". W pierwszym wypadku nauczyciele koncentrują się przede wszystkich na ograniczeniach w przyswajaniu wiedzy wynikających z niepełnosprawności, w drugim zaś na optymalnych sposobach nauczania/uczenia się podopiecznych z danym rodzajem niepełnosprawności. Istnieją dowody, że to drugie podejście zwiększa skuteczność nauczania wszystkich uczniów, gdyż identyfikujący się z nim nauczyciele rzadziej doszukują się u nich zaburzeń oraz rzadziej cedują odpowiedzialność za ich kształcenie na specjalistów i rodziców (Jordan i in. 2009). Z badań zespołu Anne Jordan wynika, że przygotowując nauczycieli do pracy w klasach włączających nie wystarczy przekazywać wiedzę o niepełnosprawności, ale należy przede wszystkim skupić się na potencjale uczniów z niepełnosprawnością i nauczać efektywnych sposobów ich kształcenia.

Innym ogólnym komponentem kompetencji zawodowych nauczycieli (obok postaw wobec edukacji włączającej) jest ich poczucie samoskuteczności w pracy z heterogenicznymi grupami uczniów - osobiste przekonanie, że są w stanie podołać zadaniom w klasie, do której uczęszczają uczniowie bez niepełnosprawności i z niepełnosprawnością (Sharma, Loreman, Forlin 2011; Malinen, Savolainen, Xu 2012). Z reguły uznaje się, że dotyczy ono subiektywnej opinii nauczycieli o ich możliwościach skutecznego działania w trzech kluczowych sferach: efektywnego kształcenia wszystkich uczniów, radzenia sobie z trudnymi zachowaniami podopiecznych oraz współpracy ze specjalistami i z rodzicami (Sharma, Loreman, Forlin 2011). Istnieją dowody empiryczne, że program kształcenia nauczycieli może mieć wpływ na ich poczucie samoskuteczności w zakresie edukacji włączającej. Badanie studentów kierunków nauczycielskich z czterech uczelni w różnych krajach (Australia, Hongkong, Kanada i Indonezja) wykazało, że umieszczenie kursów z zakresu pedagogiki specjalnej w programie studiów wpływa na wzrost poczucia saskuteczności (Loreman, Sharma, Forlin 2013). Także w omawianych wcześniej badaniach (Lifshitz, Glaubman, Issawi 2004) wykazano, że cecha ta może być kształtowana za pomocą odpowiednich szkoleń. 
Ostatni obszar kompetencji nauczycieli, istotny z punktu widzenia edukacji włączającej, to różnego rodzaju specyficzne umiejętności metodyczne i organizacyjne. Należy przede wszystkim podkreślić, że pedagodzy dobrze przygotowani do prowadzenia zajęć są wyposażeni w kompetencje metodyczne potrzebne do skutecznego nauczania w klasach włączających. Istnieją dowody na to, że metody i strategie dydaktyczne skuteczne w nauczaniu uczniów bez niepełnosprawności sprawdzają się również podczas kształcenia uczniów z niepełnosprawnością (Mitchell 2016; Vaughn, Gersten, Chard 2000). Do takich strategii zalicza się przede wszystkim: udzielanie uczniom częstych, wyczerpujących informacji zwrotnych na temat ich postępów i wzmacnianie ich motywacji do uczenia się, stosowanie metod opartych na współpracy, klarowne, dobrze ustrukturyzowane prezentowanie materiału z wykorzystaniem zasad uniwersalnego projektowania zajęć, umiejętne stosowanie technologii informacyjnych do indywidualizowania nauczania i upoglądowienia materiału, a także efektywne zagospodarowanie czasu lekcji.

Oprócz tego istnieje grupa umiejętności specyficznych. Zalicza się do nich opracowywanie Indywidualnych Planów Kształcenia (w Polsce znanych jako Indywidualne Programy Edukacyjno-Terapeutyczne) oraz monitorowanie ich realizacji i modyfikowanie zależnie od potrzeb, rozwijanie kompetencji społecznych uczniów i kształtowanie prawidłowych relacji w heterogenicznych grupach rówieśniczych oraz zdolność do współpracy w wielospecjalistycznych zespołach, która jest związana ze znajomością odpowiedniej terminologii i sposobów myślenia osób o różnym wykształceniu (Blacker, Boakes 2010; Europejska Agencja 2012). 


\subsubsection{Zróżnicowane grupy uczniów - jakie problemy?}

Grzegorz Szumski

Współczesne uwarunkowania rozwoju społeczeństw i systemów edukacyjnych nie pozostawiają nam możliwości większego wpływu na różnicowanie się klas szkolnych i grup wychowawczych. Proces ten po prostu następuje, a teoria i praktyka pedagogiczna muszą poszukiwać optymalnych sposobów reagowania na zmieniającą się rzeczywistość. Główną odpowiedzią na te wyzwania jest koncepcja edukacji włączającej, której poświęcona jest ta książka. Nie należy oczywiście lekceważyć faktu, że duża heterogeniczność klas szkolnych i grup wychowawczych stanowi poważne wyzwanie dla nauczycieli i wychowawców. Niniejszy podrozdział poświęcony jest analizie właśnie tych wyzwań i możliwych sposobów radzenia sobie z nimi. Rozpoczniemy od prezentacji rozwiązań organizacyjno-metodycznych lekcji, którymi potencjalnie dysponują nauczyciele i które mogą służyć dostosowywaniu procesu nauczania do zróżnicowanych potrzeb uczniów. Następnie omówimy specyficzne cechy uczniów z lekką niepełnosprawnością intelektualną, wskazując, które propozycje metodyczne mogą być dla nich odpowiednie. Objętość opracowania nie pozwala na taką analizę w odniesieniu do wszystkich rodzajów niepełnosprawności. $Z$ tego powodu wybraliśmy tę, która jest najczęstszą przyczyną orzekania potrzeby kształcenia specjalnego w Polsce. Omawiany przykład ma czytelnikom uświadomić złożoność problemów dydaktycznych, z którymi muszą zmagać się nauczyciele.

Najważniejszym ich zadaniem w edukacji włączającej jest takie przygotowywanie i prowadzenie zajęć oraz lekcji, aby mogli z nich efektywnie korzystać uczniowie o zróżnicowanych potrzebach. W pewnym 
uproszczeniu można powiedzieć, że dwa typy sytuacji na takich lekcjach są niepożądane, a zatem zadaniem nauczyciela jest ich eliminowanie (lub przynajmniej minimalizowanie). Pierwszy to taki, gdy zajęcia edukacyjne są niedostosowane do specyficznych cech niektórych uczniów. Są oni zatem obecni w klasie, ale ze względu na nieadekwatne dla nich treści, sposób ich przekazu lub zadania nie robią postępów. Sytuacja druga występuje wtedy, gdy w jednej sali lekcyjnej realizowane są w praktyce dwie różne ścieżki edukacyjne - osoby z orzeczeniem o potrzebie kształcenia specjalnego nauczane są stale czegoś innego, w inny sposób i przez innego pedagoga niż ich koledzy i koleżanki. Ta sytuacja jest oczywiście możliwa tylko wtedy, gdy w klasie pracuje równocześnie co najmniej dwóch nauczycieli.

Istnieją dwie kluczowe strategie, które można wykorzystywać w klasach włączających po to, aby eliminować wspomniane sytuacje niepożądane, a tym samym zwiększać adekwatność lekcji do zróżnicowanych potrzeb uczniów, zapewniając jednocześnie spójność prowadzonych zajęć edukacyjnych. Są to: uniwersalne projektowanie oraz indywidualizacja nauczania.

Uniwersalne projektowanie nauczania (universal design for learning, UDL) jest bardzo popularną strategią doskonalenia kształcenia, rozwijaną w świecie od około trzech dekad. Ponieważ wiele ważnych informacji na jej temat zostało zawartych w odrębnym rozdziale tej książki, tutaj ograniczymy się tylko do interesujących kwestii dla tego wywodu. Głównym celem projektowania uniwersalnego jest zwiększenie możliwości osiągania tych samych celów przez różnych użytkowników, a w edukacji - uczestników tego samego procesu. Zakłada się zatem, że uniwersalne rozwiązania są korzystne dla szerokiej grupy odbiorców, a jednocześnie nie są szkodliwe dla żadnego odbiorcy. Dobrze ilustrują to dwa przykłady zaczerpnięte z architektury, gdzie zrodził się ten pomysł. Szersze drzwi do domu są korzystne nie tylko dla osób jeżdżących na wózkach inwalidzkich, ale także dla pracowników prowadzących remont domu, osób otyłych, rodziców wprowadzających wózek dziecięcy czy ludzi nieuważnych, którzy w wąskim przejściu mogą zniszczyć swoje ubranie. Z rozwiązania tego korzystają także "zwykli" ludzie - po prostu jest im wygodniej dostać się do pomieszczenia. Napisy brajlowskie na przyciskach w windzie ułatwiają życie osobom niewidomym, a przez pozostałych użytkowników są po prostu ignorowane. W nauczaniu o wiele trudniej o tego typu rozwią- 
zania ze względu na specyfikę tego procesu (Edyburn 2010). Istnieją trzy komponenty procesu nauczania/uczenia się, które mogą stanowić bariery dla niektórych grup uczniów i którym potencjalnie może zaradzić UDL: percepcja materiału (treści i poleceń), planowanie zadań, a zwłaszcza ich wykonywania, oraz motywacja do uczenia się i wiara w to, że uczeń zrealizuje zadania szkolne lub poczyni satysfakcjonujące postępy (Pisha, Coyne 2001).

Efektywne wykorzystanie UDL do zapobiegania wskazanym ograniczeniom zależy w znacznej mierze od wybieranych przez nauczycieli strategii nauczania. Niestety, UDL ma ograniczone zastosowanie w nauczaniu frontalnym, które sprawia największe problemy w klasach włączających, a jednocześnie często jest stosowane w polskich szkołach. W praktyce przy zastosowaniu tej strategii największa przestrzeń pozostaje dla wielomodalnego przekazu informacji bądź przekazu głównego, uzupełnianego informacją dodatkową, np. gdy nauczyciel mający zamiar omawiać jakiś temat wyjaśnia wcześniej kluczowe pojęcia lub wyświetla ich objaśnienia za pomocą rzutnika. Dużo szersze możliwości wykorzystania UDL daje praca indywidualna. Na przykład niezwykle efektywne są zaawansowane komputerowe programy edukacyjne, które dobierają uczącemu się kolejne zadania na podstawie oceny jego aktualnych umiejętności (Holmes, Gathercole, Dunning 2009). Dzieje się tak dlatego, że aplikacje tego rodzaju dostarczają uczniom zadania adekwatne do ich możliwości, a zatem tworzą sytuacje ułatwiające rzeczywiste uczenie się, budują „rusztowania” potrzebne do zdobywania bardziej zawansowanych umiejętności i zwiększają wiarę uczniów w ich możliwości, umożliwiając im odnoszenie sukcesów. Chociaż przywołany przykład ma małe znaczenie praktyczne z powodu ograniczonej podaży tego typu programów, to dobrze obrazuje dwie ważne kwestie. Po pierwsze, choć wspomniany program jest zaprojektowany zgodnie z zasadami UDL (zwiększa efektywność nabywania tej samej kompetencji, osiągania tego samego celu) przez wszystkich użytkowników, to mechanizm jego działania bazuje na zasadzie indywidualizacji. W praktyce istnieje bardzo nieostra granica między UDL a indywidualizacją nauczania. Po drugie, program działa dzięki wykorzystaniu zaawansowanych technologii informacyjnych. Istnieje oczywiście wiele materiałów metodycznych zaliczanych do UDL, które nie wymagają skomplikowanych rozwiązań technicznych (por. Rapp 2014), ale to jednak technologia w największym stopniu 
wpływa na zwiększanie uniwersalności nauczania (Edyburn 2010). Podsumowując, UDL jest z pewnością użyteczne dla edukacji włączającej, jednak nie rozwiązuje wszystkich problemów związanych z efektywnym nauczaniem grup heterogenicznych. Ponadto strategia ta nie jest intuicyjna ani tożsama z dobrymi praktykami dydaktycznymi. Potrzebne są zarówno materiały metodyczne niezbędne do jej stosowania, jak i specjalne szkolenia dla nauczycieli, które powinny być oferowane zarówno na etapie kształcenia, jak i doskonalenia zawodowego (Edyburn 2010).

Konstruktywną odpowiedzią na wiele specjalnych potrzeb edukacyjnych, których nie jest w stanie zaspokoić UDL, jest indywidualizacja nauczania. Warto zwrócić uwagę, że nie będzie ona możliwa, gdy zastosuje się nauczanie frontalne, czyli przekazywanie jednocześnie całej klasie tych samych treści (choć w tej sytuacji można wykorzystać UDL). Indywidualizacja polega na różnicowaniu oddziaływań kierowanych do poszczególnych uczniów w taki sposób, aby nauczanie było dostosowane do każdego z nich (Deunk, Smale-Jacobse, de Boer, Doolaard, Bosker 2018).

Każdy wymiar procesu nauczania/uczenia się może podlegać zróżnicowaniu, szczególnie cele i związany z nimi zakres treści, stopień trudności zadań i czas na ich wykonanie, a nie tylko sposoby nabywania tej samej wiedzy (Konarzewski 2011). James M. Kauffman od wielu lat upowszechnia pogląd, że duża intensywność indywidualizacji kształcenia jest konstytutywną cechą kształcenia specjalnego (por. Kauffman, Hung 2009). Nie kwestionuje on popularnego wśród zwolenników edukacji włączającej poglądu, że „to, co jest dobre dla uczniów z niepełnosprawnością, jest dobre dla pozostałych". Zatem umiejętne indywidualizowane lekcji, oparte na starannym rozpoznawaniu postępów poszczególnych uczniów, może przynosić korzyści wszystkim, także tym z potrzebą kształcenia specjalnego. Jest to zatem bardzo ważna strategia nauczania w klasach włączających. Trzeba jednak zaakceptować fakt, że niektóre osoby potrzebują tak intensywnej indywidualizacji nauczania, że nie można im jej zapewnić w klasie z jednym nauczycielem, który ponadto nie posiada gruntownego wykształcenia w zakresie pedagogiki specjalnej (Kauffman, Mock, Ward, Badar 2016). Sytuacja ta dotyczy uczniów, którzy ze względu na obecny poziom rozwoju muszą nabywać kompetencje kluczowe, które ich koledzy opanowali wcześniej (np. nauka czytania od podstaw w sytuacji, gdy reszta klasy już dobrze czyta i wykorzystuje tę umiejętność do zdobywania nowej wiedzy), 
potrzebują bardzo częstych informacji zwrotnych ukierunkowujących ich aktywność (których nie da się zapewnić przez dokładniejszą strukturalizację materiałów dydaktycznych) oraz bardzo częstych objaśnień materiału. W takich sytuacjach trudno mówić o pełnym, wspólnym uczestnictwie w lekcji nawet wtedy, gdy wszyscy uczniowie przebywają w jednym pomieszczeniu. Odpowiedni dla takiego zespołu sposób pracy zwykło się nazywać nauczaniem bezpośrednim. Polega on na tym, że nauczyciele, pracując "twarzą w twarz" z pojedynczymi osobami lub niewielkimi grupami, tłumaczą materiał podzielony na małe części, rozdzielają zadania lub stawiają pytania. Pozwala to kontrolować proces przyswajania poszczególnych partii wiedzy i opanowania umiejętności składowych danej kompetencji, a także natychmiast korygować błędy uczniów, co oznacza, że nauczyciele bezpośrednio kierują procesem uczenia się (Hornby 2014). Uczniowie z poszczególnymi rodzajami specjalnych potrzeb edukacyjnych różnią się zapotrzebowaniem na tego typu kształcenie. Trzeba dodać, że wymagania takie występują nie tylko u osób z głębszymi niepełnosprawnościami poznawczymi i niepełnosprawnościami sprzężonymi, ale także u wielu uczniów z dysfunkcjami Iżejszymi, wymagającymi mniej intensywnego wsparcia.

Mówiąc o wyzwaniach stojących przed nauczycielami, którzy mają efektywnie zajmować się heterogenicznymi grupami uczniów, warto wskazać nie tylko na czynniki substancjalne, wynikające właśnie z różnorodności grupy, ale także na trudności z zapewnieniem stosownych zasobów. Zarówno UDL, jak i nowoczesna indywidualizacja nauczania nie są rozwiązaniami intuicyjnymi, które mogą być efektywnie wdrażane przez przeciętnie wykształconych pedagogów bez wcześniejszego specjalnego przygotowania. Oba wymienione podejścia zawierają ogólne zasady, ale są dzisiaj w istocie zbiorem zamkniętych pakietów metodycznych, które nauczyciele muszą poznać i do stosowania których muszą otrzymać odpowiednie pomoce. W odniesieniu do indywidualizacji dobrze obrazuje to systematyczny przegląd opracowany przez Krzysztofa Konarzewskiego (2011). Badania wskazują ponadto, że stosowanie UDL, a zapewne także zaawansowanej indywidualizacji, stanowi duże obciążenia dla nauczycieli - wymaga od nich zwiększenia wysiłku i nakładów pracy, a także intensywniejszej współpracy ze specjalistami niż rozwiązania tradycyjne (Katz 2014). Chociaż dostosowywanie działań edukacyjnych do potrzeb zróżnicowanych grup uczniów jest koniecznością, to nie powinno być traktowane jako panaceum na 
wszelkie problemy. Badania efektywności indywidualizacji nauczania wskazują, że pozytywne rezultaty o wiele łatwiej uzyskać dzięki całościowym programom, do wdrażania których nauczyciele są gruntownie przygotowywani, a niejednokrotnie także wspierani przez specjalistów (Deunk, Smale-Jacobse, de Boer, Doolaard, Bosker 2018). Nieumiejętne indywidualizowanie nauczania może prowadzić do nieuzasadnionego obniżania wymagań i utrwalania u uczniów nieefektywnych strategii uczenia się (Corno 2008).

Z kolei skuteczność strategii UDL, ze względu na dużo krótszą historię tego rozwiązania, jest o wiele słabiej udokumentowana naukowo. Zdecydowana większość dostępnych analiz w zakresie jakości procesu nauczania i motywacyjnych cech uczniów przynosi obiecujące wyniki. Wskazuje się zatem na to, że UDL poprawia relacje nauczyciela z uczniami, redukuje stres szkolny uczniów, zwiększa ich zaangażowanie w zdobywanie wiedzy i podnosi ich poczucie samoskuteczności (Capp 2017). Ponieważ czynniki te wiązane są z większą efektywnością kształcenia, można racjonalnie oczekiwać, że UDL prowadzi także do poprawienia osiągnięć szkolnych. Brakuje jednak dowodów naukowych, które bezpośrednio potwierdziłyby tę tezę. Co więcej, nie ma także takich, które dotyczą efektywności UDL w pracy z osobami z poszczególnymi rodzajami niepełnosprawności. Nawet wyniki badań prowadzonych w klasach włączających nie są analizowane odrębnie dla tych grup uczniów (Capp 2017), co stanowi znaczne ograniczenie. Z badań efektywności indywidualizacji wiemy bowiem, że poszczególne rozwiązania nie przynoszą uniwersalnych skutków. Na przykład ewaluacje jednego z najpopularniejszych programów indywidualizacji nauczania w klasach włączających - ALEM - szczegółowo omówionego przez Konarzewskiego (2011), wykazały, że prowadzi on do poprawienia osiągnięć szkolnych uczniów z niepełnosprawnością, ale nie ma analogicznego wpływu na osiągnięcia pozostałych osób w klasie (Fuchs, Fuchs 1998).

Najliczniejszą grupą z orzeczeniami o potrzebie kształcenia specjalnego w Polsce są uczniowie z lekką niepełnosprawnością intelektualną. Stosunkowo często trafiają oni do szkół ogólnodostępnych i szkół (klas) integracyjnych. Przy okazji omawiania tej grupy warto wspomnieć, że do szkół ogólnodostępnych uczęszczają także osoby z inteligencją niższą niż przeciętna (borderline intellectual functioning), które nie mają wprawdzie orzeczeń o potrzebie kształcenia specjalnego, ale ich funkcjonowanie w środowisku szkolnym bardzo często przypomina 
sytuację uczniów z lekką niepełnosprawnością intelektualną (Peltopuro, Ahonen, Kaartinen, Seppälä, Närhi 2014). Sposób funkcjonowania poznawczego tej grupy ma wpływ na organizację adekwatnego do ich potrzeb nauczania w klasach włączających. Uczniowie z lekką niepełnosprawnością intelektualną mają wyraźnie większe trudności w rozumieniu nowego materiału i instrukcji do zadań niż ich rówieśnicy o prawidłowym rozwoju. Trudności te spowodowane są zarówno niższą wydolnością uwagi, osłabioną sprawnością funkcji poznawczych (spostrzeganie, zapamiętywanie czy myślenie), jak i opóźnieniami w rozwoju języka, który jest głównym narzędziem przekazywania materiału i instrukcji w szkole (Chrzanowska 2015; Hornby 2014). Cechy te sprawiają, że wiele standardowo stosowanych przez nauczycieli objaśnień nowego materiału lub instrukcji do pracy samodzielnej uczniów (indywidualnej lub grupowej) może być niezrozumiałych dla tych z lekką niepełnosprawnością intelektualną lub inteligencją niższą niż przeciętna. Pewne możliwości przeciwdziałania temu problemowi dają techniki uniwersalnego projektowania nauczania (np. objaśnianie trudniejszych pojęć, uzupełnianie przekazu słownego materiałem wizualnym czy wcześniejsze dostarczanie materiałów wprowadzających do nowego zagadnienia), ale w wielu sytuacjach mogą być one niewystarczające. Kluczową strategią powinno być zastąpienie frontalnego podawania materiału wszystkim uczniom oraz pogadanek prowadzonych z całą klasą innymi sposobami przekazywania wiedzy. Forma pisemna daje dużo większe możliwości w zakresie adaptacji materiału i instrukcji, jednak i ona wymaga od nauczycieli znacznego wysiłku przy opracowaniu materiałów dydaktycznych lub adaptacji istniejących, oferowanych przez wydawców.

Inną cechą osób z lekką niepełnosprawnością intelektualną są ograniczenia w zakresie planowania czynności poznawczych, które w połączeniu z dużą niepewnością w uczeniu się i słabą koncentracją uwagi tworzą specyficzne uwarunkowania procesu aktywnego zdobywania wiedzy przez samodzielną naukę. Metodycy od lat słusznie zalecają dzielenie materiału na mniejsze partie (Hornby 2014; Rola 2011). Jednak szkoła musi także aktywnie rozwijać zdolność uczniów do rozwiązywania coraz bardziej złożonych problemów, a skuteczną drogą do osiągnięcia tego celu jest udzielanie częstej informacji zwrotnej w trakcie pracy nad dłuższymi i wieloetapowymi zadaniami szkolnymi. Nauczyciel musi mieć zatem w trakcie lekcji czas na to, żeby wielokrot- 
nie podejść do ucznia, by zapewnić go o tym, że pracuje prawidłowo lub udzielić informacji ukierunkowujących jego dalszą aktywność (Kowalik 1989). Żeby to było możliwe, pedagodzy powinni tak organizować proces kształcenia, aby pozostali uczniowie byli na lekcji możliwie najbardziej samodzielni. Kluczowym sposobem zapewniania takich warunków jest nauczanie otwarte, przystępnie opisane w poradniku metodycznym Bernda Badegrubera (1997).

Podsumowując, należy powiedzieć, że nauczanie w grupach silnie zróżnicowanych jest dla nauczycieli dużym wyzwaniem. Efektywności tego procesu nie uda się uzyskać wyłącznie przez modyfikację frontalnego sposobu nauczania, często stosowanego w tradycyjnych klasach. Dostosowanie kształcenia do zróżnicowanych potrzeb uczniów wymaga stosowania elastycznych rozwiązań, w tym UDL i indywidualizacji. Jednak odpowiedzialne używanie tych strategii wymaga starannego przygotowania, odpowiednich zasobów metodycznych, a niejednokrotnie także wsparcia ze strony specjalistów. Należy ponadto pamiętać, że nauczyciel nie jest $w$ stanie zaspokoić potrzeb edukacyjnych wszystkich uczniów z niepełnosprawnością. Nawet ci z tzw. lekkimi niepełnosprawnościami wymagają niejednokrotnie intensywnego, bezpośredniego nauczania niektórych umiejętności. Osobami przygotowanymi do takiej pracy są pedagodzy specjalni. 


\subsection{Edukacja włączająca w badaniach naukowych - perspektywa ucznia}

Wyniki badań naukowych dotyczących sytuacji ucznia w edukacji włączającej wskazują, że sukces podejmowanych działań zależy od wielu uwarunkowań. Są wśród nich kompetencje społeczne uczniów z niepełnosprawnością, ze specjalnymi potrzebami edukacyjnymi, a także sprawnych, które mogą się przekładać na prawidłowe lub nieprawidłowe relacje rówieśnicze. Analizy dotyczące osiągnięć szkolnych uczniów z niepełnosprawnościami wskazują, że nieco lepsze wyniki uzyskują oni w edukacji włączającej niż w specjalnej. Badania potwierdzają również, że edukacja włączająca stwarza korzystniejsze warunki rozwoju kompetencji społecznych. Konieczne są jednak dalsze prace badawcze $w$ tej dziedzinie. 


\subsection{Inclusive education in scientific research - the student's perspective}

The results of scientific research on the student's in inclusive education indicate a number of conditions for the success of undertaken activities. Among them are the social competences of pupils with disabilities and with special educational needs, as well as students without any disabilities, which can result in proper or incorrect peer relationships. Analyzes regarding school achievements of students with disabilities indicate that they achieve slightly better results in inclusive education than in special education. Research also confirms that inclusive education creates more favorable conditions for the development of their social competences. However, future research in this area is necessary.

\section{Keywords:}




\title{
1.4.1. Osiągnięcia szkolne - jakie uwarunkowania?
}

\author{
Grzegorz Szumski
}

Znaczenie edukacji włączającej dla osiągnięć szkolnych uczniów z niepełnosprawnością budzi powszechne zainteresowanie naukowców, polityków oświatowych i rodziców od momentu pojawienia się tej koncepcji. $Z$ tego powodu przeprowadzono wiele badań na ten temat, co nie znaczy, że zagadnienie nie budzi już żadnych kontrowersji. Istnieje bowiem wiele obiektywnych trudności z gromadzeniem przekonujących dowodów na efektywność kształcenia uczniów w ramach edukacji włączającej. Po pierwsze, może być ona inaczej definiowana w różnych krajach i przez różnych badaczy, co prowadzi do tego, że proste porównywanie wyników badań często nie jest uprawnione. Po drugie, może być wdrażana na wiele sposobów. Przy ocenie jej znaczenia dla osiągnięć szkolnych należy zatem uwzględniać także ten czynnik, tymczasem w wielu badaniach nie kontroluje się różnych aspektów metodycznych, a jedynie samą formę kształcenia. Po trzecie, uczniowie z niepełnosprawnością stanowią bardzo heterogeniczną grupę. Różnią się oni nie tylko rodzajem niepełnosprawności, ale także jej stopniem, zaburzeniami współwystępującymi, środowiskiem rodzinnym i innymi czynnikami, które mogą wpływać na ich osiągnięcia edukacyjne. Kontrola tych elementów $w$ badaniach jest niejednokrotnie bardzo trudna. Ponieważ $w$ wielu krajach osoby z niepełnosprawnością nie trafiają do form włączających losowo, bardzo trudno znaleźć porównywalne próbki uczniów w klasach włączających i szkołach specjalnych. Po czwarte, brakuje wiarygodnych narzędzi oceny ilościowej osiągnięć szkolnych osób z niepełnosprawnością. Braki te są szczególnie silnie odczuwane w odniesieniu do uczniów z niepełnosprawnością głębszą i złożoną, których programy kształcenia mają charakter raczej funkcjonalny niż akademicki. 
Uwzględnienie wszystkich wskazanych ograniczeń pozwoli czytelnikowi zbudować pełniejszy, co nie znaczy, że bardziej jednoznaczny, obraz wpływu edukacji włączającej na osiągnięcia szkolne uczniów z niepełnosprawnościami. Nasze analizy rozpoczniemy od prezentacji wyników badań, które z założenia służą odpowiedzi na bardziej ogólne pytanie, by w kolejnych krokach rozważać najważniejsze kwestie szczegółowe dotyczące osiągnięć omawianej grupy w edukacji włączającej i w szkolnictwie specjalnym.

Z systematycznych przeglądów badań w tym zakresie, zarówno jakościowych, jak i ilościowych, zwanych metaanalizami, wyłania się spójny obraz rzeczywistości. Wskazują one na to, że edukacja w formach włączających przynosi nieznacznie lepsze efekty niż kształcenie $w$ tradycyjnych szkołach i klasach specjalnych. W trzech wczesnych meataanalizach, obejmujących badania prowadzone w Stanach Zjednoczonych od początku funkcjonowania edukacji włączającej do 1992 r., uzyskano pozytywne efekty o sile między 0,08 a 0,44 (Baker, Wang, Walberg 1994/1995). Zgodnie z powszechnie akceptowaną w literaturze propozycją interpretacji wyników uznaje się, że są to efekty słabe, choć najwyższy wynik z 11 badań pochodzących z lat 1975-1984 wyraźnie zbliża się do wartości umiarkowanej (Wang, Baker 1985/1986). Średnie osiągnięcia objętych tą analizą uczniów w klasach włączających zbliżają się do poziomu ok. 67 centyla wyników uczniów w szkołach specjalnych. Co więcej, rezultat ten jest niezależny od rodzaju badanej niepełnosprawności czy szczebla szkolnego. Efekt uzyskany w metaanalizie Margaret C. Wang i Edwarda T. Bakera jest wystarczająco wysoki, by traktować go jako ważny argument na rzecz upowszechniania edukacji włączającej, jeśli uwzględni się, że siła oddziaływań większości metod i rozwiązań pedagogicznych jest zbliżona bądź niższa (Hattie 2009). Opublikowana trzy dekady później metaanaliza 24 badań (91 efektów) przeprowadzonych w Stanach Zjednoczonych w latach 1980-2013 potwierdza wcześniejsze ustalenia (Oh-Young, Filler 2015). Wyliczony przez autorów efekt główny wynosi $d=0,31$, a zatem jest tylko nieznacznie niższy niż wynik otrzymany przez Margaret C. Wang i Edwarda T. Bakera (1985/1986). Podsumowując, badania realizowane w Stanach Zjednoczonych po 1975 r., a zatem po wprowadzeniu celowej polityki na rzecz wspólnego nauczania uczniów z niepełnosprawnościami i bez niepełnosprawności, wskazują, że edukacja włączająca przynosi korzyści poznawcze osobom z pierwszej grupy. Jednocze- 
śnie istnieją przesłanki, by sądzić, że efekty te nie wynikają po prostu z umieszczania uczniów z niepełnosprawnością w bardziej włączającym środowisku, lecz z korzystnych przemian, które dokonały się w szkołach na skutek upowszechniania się nowej idei. Przemiany te obejmowały zmianę świadomości i postaw nauczycieli, ale także rozbudowę zasobów specjalnopedagogicznych, poczynając od pedagogów specjalnych współorganizujących kształcenie w szkołach ogólnodostępnych przez Indywidualne Plany Edukacyjne dla uczniów, po wdrożenie nowych metod kształcenia. Przed wprowadzeniem celowych zabiegów reformatorskich nie obserwowano w Stanach Zjednoczonych lepszych osiągnięć szkolnych uczniów z niepełnosprawnością w szkołach ogólnodostępnych niż w specjalnych. Efekt główny metaanalizy Conrada Carlberga i Kennetha Kavale'a (1980), która obejmowała 50 badań przeprowadzonych w latach 1932-1970, był co prawda pozytywny, ale zdecydowały o tym wyniki uzyskiwane przez uczniów z inteligencją niższą niż przeciętna. Gdy jednak wzięto pod uwagę osoby z trudnościami w uczeniu się, z zaburzeniami emocjonalnymi i zaburzeniami zachowania, wówczas się okazało, że korzystniejszym środowiskiem kształcenia jest dla nich szkoła specjalna (Carlberg, Kavale 1980).

Niestety, dotychczas przeprowadzone metaanalizy dotyczące poruszanego tutaj tematu obejmowały jedynie badania odwołujące się do amerykańskiego systemu szkolnego. Próba odpowiedzi na pytanie, czy wyniki tych analiz i płynące z nich wnioski mają zastosowanie w Europie, w tym w Polsce, wymaga ich zestawienia z rezultatami uzyskiwanymi na Starym Kontynencie. Badań związku osiągnięć szkolnych uczniów z niepełnosprawnością z formą ich kształcenia w Europie jest niespodziewanie mało, biorąc pod uwagę to, jak wiele krajów stara się upowszechniać edukację włączającą. W światowych bazach danych literatury przedmiotu z pierwszej dekady XXI w. Nienke M. Ruijs i Thea T.D. Peetsma (2009) znalazły tylko wyniki badań z Holandii (Jepma 2003; Karsten, Peetsma, Roeleveld, Vergeer 2001; Peetsma, Vergeer, Roeleveld, Karsten 2001) i z Norwegii (Markussen 2004; Myklebust 2007). W następnej dekadzie opublikowano dodatkowo wyniki badań uczniów szwajcarskich (Sermier Dessemontet, Bless, Morin 2012) i polskich (Szumski, Karwowski 2014). Łącznie zatem dysponujemy tylko siedmioma publikacjami prezentującymi porównania osiągnięć szkolnych uczniów z niepełnosprawnością kształconych w formach włączających i segregacyjnych z czterech krajów. Przedstawione w nich 
wyniki mają w większości charakter pozytywny, tzn. wskazują, że dzięki edukacji włączającej uczniowie mogą się pochwalić lepszymi osiągnięciami szkolnymi niż ich rówieśnicy ze szkół specjalnych. Niektóre badania pokazują, że forma kształcenia nie ma wpływu na osiągnięcia edukacyjne, żadne z nich nie wskazuje na przewagę szkół specjalnych w tym zakresie.

Siły efektów obserwowane w badaniach europejskich nie są wysokie, nawet nieco niższe niż w metaanalizach amerykańskich. Wyniki analizy prowadzonej w Polsce na dużej próbie osób z lekką niepełnosprawnością intelektualną na koniec edukacji elementarnej wykazały, że zarówno uczniowie klas integracyjnych $(d=0,21)$, jak i ogólnodostępnych $(d=0,23)$ uzyskują wyniki nieco lepsze niż ich rówieśnicy ze szkół specjalnych (Szumski, Karwowski 2014). Warto zwrócić uwagę, że badania europejskie nieco różnią się od tych włączanych do amerykańskich metaanaliz cechami, które mogą mieć znaczenie dla uzyskiwanych wyników. Dotyczą one węższego spektrum rodzajów niepełnosprawności, analizowanego zakresu wieku i charakteru wdrażania edukacji włączającej. W badaniach europejskich, których wyniki publikowano w literaturze międzynarodowej, brali udział uczniowie z często występującymi i jednocześnie względnie lekkimi rodzajami niepełnosprawności (trudności w uczeniu się, zburzenia zachowania, lekka niepełnosprawność intelektualna), podczas gdy metaanalizy amerykańskie uwzględniały także osoby niesłyszące, z autyzmem czy niepełnosprawnością złożoną (Oh-Young, Filler 2015). W Europie uwzględniano młodszych uczniów, podczas gdy próby amerykańskie są bardziej zróżnicowane pod tym względem. Ponieważ wymienione założenia europejskich badań czynią włączanie łatwiejszym, należy uwzględnić, że wyniki mogą dawać nieco zbyt optymistyczny obraz efektywności edukacji włączającej. Z drugiej strony, wszystkie wspominane badania pochodzą z systemowych baz danych lub prób losowych. Tymczasem część amerykańskich dotyczy ewaluacji celowych projektów wdrożeniowych, w których edukację włączającą wprowadzano przy wsparciu lokalnych uniwersytetów, zgodnie z metodyką wypracowaną przez naukowców wraz z praktykami, co bardzo sprzyja zwiększaniu jej efektywności (McLeskey, Waldron, Reed 2014).

Na podstawie literatury krajowej możemy zbudować dokładniejszy obraz skuteczności edukacji włączającej w Polsce. Marzena Buchnat (2015) zgromadziła dane wskazujące na nieco wyższą efektywność 
kształcenia uczniów z niepełnosprawnością intelektualną w stopniu lekkim w szkolnictwie specjalnym niż w formach włączających. Badani przez nią uczniowie klas IV szkół specjalnych mieli wyższe umiejętności matematyczne niż ich rówieśnicy ze szkół ogólnodostępnych. Porównanie tych dwóch grup wskazywało też na przewagę biegłości językowej uczniów szkół specjalnych nad tymi ze szkół ogólnodostępnych. Nie stwierdzono za to różnic między kompetencjami uczniów szkół specjalnych i klas integracyjnych. Wyniki te są sprzeczne z wcześniejszymi badaniami Iwony Chrzanowskiej (2003) i Grzegorza Szumskiego (2010), prowadzonymi na osobach z tą samą niepełnosprawnością. Istotnie wyższe osiągnięcia językowe uczniów z zaburzeniami wzroku w szkołach integracyjnych niż specjalnych zaobserwowała Beata Papuda-Dolińska (2017). Takiej przewagi edukacji włączającej nie stwierdzono w odniesieniu do matematyki oraz klas ogólnodostępnych.

Podsumowując, można powiedzieć, że efektywność edukacji włączającej w Polsce nie odbiega znacznie od obserwowanej w innych państwach europejskich. Wyniki krajowe nie są jednak tak jednoznaczne - mniej jest pozytywnych, a więcej neutralnych i negatywnych. Wyniki niekorzystne dla edukacji włączającej pochodzą przede wszystkim ze szkół ogólnodostępnych, w których wsparcie ze strony pedagogów specjalnych jest ograniczone. Przemawia to za potrzebą poszerzenia dostępu placówek tego typu do specjalnopedagogicznych zasobów i ogólnego doskonalenia modelu edukacji włączającej w Polsce.

Rezultaty badań wskazują, że osiągnięcia szkolne uczniów z niepełnosprawnością w edukacji włączającej są zróżnicowane, co skłania do poszukiwania czynników, które mają na nie wpływ. Uwaga badaczy koncentruje się oczywiście na tych, które mogą być kształtowane przez odpowiednią politykę edukacyjną i praktyki pedagogiczne, choć wskazuje się także na elementy niezależne od pedagogów i polityków edukacyjnych.

Pedagodzy mają wpływ na czynniki na dwóch poziomach: szkoły (to czynniki związane z ogólnym sposobem rozumienia edukacji włączającej i strategiami jej wdrażania) oraz klasy (czynniki zależne od praktyk dydaktycznych nauczycieli) (Erten, Savage 2012). Wiele badań prowadzonych w różnych krajach wskazuje, że bardzo istotną determinantą efektywności włączania jest to, czy proces ten jest pojmowany jako dodatkowy program zaspokajania specjalnych potrzeb uczniów z niepełnosprawnością, czy też jako integralny, przewodni motyw funkcjonowania szkoły. Ta druga sytuacja jest o wiele korzystniejsza (McLeskey, 
Waldron, Reed 2014). W praktyce oznacza ona intensywne, skoordynowane na poziomie całej placówki edukacyjnej, wspólne działania wszystkich specjalistów na rzecz zaspokajania potrzeb ogółu uczniów i stałego doskonalenia pracy pedagogicznej. Taka organizacja pozwala lepiej wykorzystać istniejące zasoby szkoły i przeciwdziała cedowaniu odpowiedzialności za kształcenie uczniów z niepełnosprawnością wyłącznie na pedagogów specjalnych.

W efektywnych szkołach włączających obserwuje się także specyficzną kulturę, której kluczowymi elementami są: wysokie oczekiwania wobec wszystkich uczniów i stałe wysiłki na rzecz doskonalenia sposobów nauczania, intensywne wzajemne wspieranie się wszystkich pedagogów w klimacie zaufania oraz podejmowanie pracy pedagogicznej również poza lekcjami. Takie podejście sprzyja wykorzystywaniu efektywnych modeli współpracy nauczycieli i pedagogów specjalnych w klasie. Modele te wymagają codziennej współpracy w zakresie przygotowania lekcji. Zastosowanie takich rozwiązań jak stacje zadaniowe czy nauczanie w małych, heterogenicznych grupach wyraźnie poprawia rezultaty kształcenia, ale wymaga wspólnego planowania i wspólnej realizacji zajęć. Efektywność tych rozwiązań jest wynikiem częstszego, lepszego wsparcia dorosłych (co wiąże się z przekazywaniem większej liczby informacji zwrotnych), a także intensywnego kontaktu dzieci z niepełnosprawnością ze sprawnymi rówieśnikami. Tworzenie warunków owocnych interakcji zwiększa możliwość modelowania zachowań uczniów bez dysfunkcji, korzystania z ich wskazówek. Ogólne rzecz ujmując - sprzyja wspólnemu konstruowaniu wiedzy.

Wysokie oczekiwania nauczycieli względem wszystkich uczniów zapobiegają także stosowaniu niewłaściwie pojmowanej indywidualizacji, która sprowadza się do stawiania osobom z niepełnosprawnością zadań wyraźnie niższych niż ich możliwości poznawcze (Palak 2000). Negatywny efekt błędnie wdrażanej indywidualizacji został udowodniony w kilku badaniach klas włączających (np. Peetsma i in. 2001). Wielu badaczy zwraca także uwagę na szkodliwość nadmiernej bezpośredniej pomocy udzielanej uczniom z niepełnosprawnością przez pedagogów specjalnych, w sytuacji, gdy pracuje ich w klasie zbyt wielu (Markussen 2004). 


\title{
1.4.2. Kompetencje społeczne - jakie szanse?
}

\author{
Grzegorz Szumski
}

Rozwijanie kompetencji społecznych uczniów to jedno z zadań pracy wychowawczej każdej szkoły. Nie jest zatem niczym zaskakującym, że $w$ tej sferze także polskie prawo oświatowe nakłada na nauczycieli obowiązek wspomagania rozwoju uczniów. Podstawa programowa wychowania przedszkolnego definiuje wprost obszar "społecznego rozwoju dziecka". W podstawie programowej kształcenia ogólnego dla szkoły podstawowej treści związane z rozwijaniem kompetencji społecznych są bardziej rozproszone, ale także obecne (Rozporządzenie Ministra Edukacji Narodowej z dnia 14 lutego 2017 r.). Zostały one zaliczone do grupy ośmiu kompetencji kluczowych w procesie uczenia się przez całe życie przez Parlament Europejski i Radę Unii Europejskiej (Zalecenie Parlamentu Europejskiego i Rady 2006).

Nacisk na rozwój kompetencji społecznych jest uzasadniony ich wpływem na bieżące oraz przyszłe życie dzieci i młodzieży. Istnieje bardzo dużo dowodów na to, że kompetencje te są predykcyjne dla wielu, by nie powiedzieć, że dla prawie wszystkich istotnych sfer funkcjonowania człowieka. W dzieciństwie i w okresie adolescencji pozwalają przewidywać osiągnięcia szkolne, relacje rówieśnicze i dobrostan psychiczny. Pozytywny związek kompetencji społecznych z osiągnięciami szkolnymi jest łatwy do przewidzenia na gruncie popularnych teorii rozwoju, które podkreślają kluczową rolę interakcji w procesie zdobywania wiedzy czy - szerzej rzecz ujmując - wskazują na społeczny charakter uczenia się. Do koncepcji takich zalicza się historyczno-społeczną teorię rozwoju Lwa Wygotskiego (por. Włodarski 2014) czy społeczno-konstruktywistyczną teorię uczenia się, której autorstwo przypisywane jest Jerome'owi Brunerowi (Bruner 2006). Podejścia te wskazują, że uczenie 
się jest aktywnym konstruowaniem wiedzy, a proces ten ma z założenia charakter społeczny i najczęściej odbywa się w interakcji zarówno z nauczycielami, jak i z rówieśnikami. Częstotliwość i jakość tych kontaktów zależy od umiejętności społecznych. Wiele badań podłużnych wskazuje na to, że uczniowie o wyższych kompetencjach czynią większe postępy w szkole. Na przykład w badaniu 294 dzieci włoskich wykazano, że ich kompetencje prospołeczne mierzone w III klasie szkoły podstawowej pozwalają wyjaśnić aż 35\% wariancji ich osiągnięć szkolnych pięć lat później (Caprara, Barbaranelli, Pastorelli, Bandura, Zimbardo 2000). W innej analizie wykazano, że wyższe kompetencje społeczne przedszkolaków zwiększają ich szanse na ukończenie szkoły średniej (Vitaro, Brendgen, Larose, Tremblay 2005).

Związek między kompetencjami społecznymi a relacjami rówieśniczymi uczniów wydaje się na tyle oczywisty, że nie wymaga szerszego wyjaśnienia. Zgromadzono bardzo wiele dowodów na to, że niskie umiejętności społeczne skutkują ubogimi relacjami z rówieśnikami, brakiem przyjaciół i częstym odrzuceniem przez koleżanki i kolegów (Deptuła 2013). Odpowiednie wyrażanie zainteresowania innymi, inicjowanie wspólnych aktywności i przyłączanie się do działań grup rówieśników, a także konstruktywne uczestnictwo w pracach nastawionych na osiąganie wspólnych celów, dzielenie się, negocjowanie ról czy społecznie akceptowane i efektywne rozwiązywanie konfliktów to czynniki, które warunkują udane kontakty z otoczeniem (Jamison, Forston, Stanto-Chapman 2012). Braki w tym zakresie prowadzą do tego, że dzieci wycofują się z kontaktów z rówieśnikami lub przejawiają w interakcjach zachowania destrukcyjne, agresywne i prowokacyjne (Howes, Phillipsen 1998; Kopp, Baker, Brown 1992). To z kolei obniża ich szanse na konstruktywne kontakty w przyszłości, a tym samym zmniejsza liczbę okazji do nabywania umiejętności społecznych. Niskie kompetencje w tym zakresie są także wyraźnym predyktorem słabego dobrostanu psychicznego, wyrażającego się np. niską samooceną lub nasilonymi symptomami depresyjnymi (Mazza, Fleming, Abbott, Haggerty, Catalano 2010; Holopainen, Lappalainen, Junttila, Savolainen 2012). Dzieje się tak dlatego, że uczniowie nie potrafią efektywnie zaspokajać swoich potrzeb i odnoszą relatywnie mniej sukcesów niż ich koledzy i koleżanki o wysokich umiejętnościach społecznych, a dodatkowo otrzymują ograniczone wsparcie emocjonalne oraz społeczne od rówieśników i osób dorosłych. 
Chociaż wiele dzieci ma niskie kompetencje społeczne, to szczególne wyzwanie pedagogiczne $w$ tym zakresie pojawia się w grupie ze specjalnymi potrzebami edukacyjnymi. Wiadomo bowiem, że umiejętności społeczne takich uczniów rozwijają się wolniej niż ich rówieśników o typowym rozwoju. W wypadku niektórych rodzajów niepełnosprawności, takich jak spektrum autystyczne, niepełnosprawność intelektualna czy zaburzenia zachowania, niskie umiejętności społeczne są osiowym objawem, immanentną cechą niepełnosprawności. W innych sytuacjach (np. uszkodzenia słuchu) stanowią konsekwencję ograniczeń w funkcjonowaniu. Niskie kompetencje społeczne osób z niepełnosprawnością to istotna przeszkoda w ich integracji społecznej - badacze dowodzą, że ok. $30 \%$ dzieci z tej grupy jest odrzucanych przez rówieśników z tego powodu (Odom, Zercher, Li, Marquart, Sandall 1998). Często wskazywane przez pedagogów specjalnych niewłaściwe postawy uczniów z niepełnosprawnościami wobec sprawnych rówieśników nie są zatem jedyną barierą w integracji społecznej, obserwowanej w wielu klasach szkolnych. Edukacja włączająca tworzy wiele naturalnych okoliczności, które mogą sprzyjać zwiększaniu kompetencji społecznych. Wheterogenicznych środowiskach wychowawczych dzieci z niepełnosprawnością mogą przede wszystkim obserwować bardziej dojrzałe zachowania społeczne rówieśników bez niepełnosprawności i uczyć się ich przez modelowanie (Guralnick 1992; Odom, Brown 1993). W odróżnieniu od klas specjalnych, w grupach integracyjnych uczniowie z niepełnosprawnością mają więcej okazji do interakcji z lepiej rozwiniętymi rówieśnikami, w trakcie których mogą rozwijać i wypróbowywać swoje umiejętności społeczne (Odom, Zercher, Marquart, Li, Sandall, Wolfberg 2002). Słusznie podkreśla się także, że uczęszczanie do szkół specjalnych często wiąże się koniecznością dalekich dojazdów lub zamieszkania w internacie, co ogranicza możliwość kontaktów z rówieśnikami i rodzeństwem bez niepełnosprawności (Nakken, Pijl 2002).

Korzystniejsze warunki rozwoju kompetencji społecznych w edukacji włączającej niż w szkolnictwie specjalnym zostały potwierdzone w wielu badaniach. Realizatorka jednego z nich - Iwona Chrzanowska (2003) - wykazała, że umiejętności społeczne uczniów z lekką niepełnosprawnością intelektualną w klasach integracyjnych są na znacznie wyższym poziomie niż u ich rówieśników ze szkół specjalnych. Do podobnych wniosków upoważniają późniejsze badania Krystyny Barłóg (2008), prowadzone na podobnej grupie. Niektóre analizy za- 
graniczne także wykazują przewagę klas włączających jako środowiska rozwoju społecznego uczniów z niepełnosprawnością (por. Ruijs, Peetsma 2009). Istnieją także takie, w których nie obserwowano różnic $w$ rozwoju w formach włączających i w szkolnictwie specjalnym. W podłużnym szwajcarskim badaniu uczniów z lekką niepełnosprawnością intelektualną nie wykryto różnic w rozwoju ich kompetencji społecznych w szkołach specjalnych i włączających w trakcie dwóch lat nauki (Dessemontet, Bless, Morin 2012). Podobne rezultaty uzyskano w polskim badaniu podłużnym uczniów z lekką niepełnosprawnością intelektualną i z zaburzeniami słuchu (Smogorzewska 2019).

Nawet jeśli edukacja włączająca może sprzyjać rozwojowi kompetencji społecznych uczniów z niepełnosprawnością (na co wskazuje wiele dowodów), to nie zawsze tak się dzieje. Z tego powodu badacze zachęcają, by nauczyciele klas włączających wdrażali programy wychowawcze, których celem jest rozwijanie umiejętności społecznych. Metodyka tego typu odziaływań jest dobrze rozwinięta, co znaczy, że wypracowano zasady wspomagania rozwoju uczniów, opracowano liczne programy do tego przeznaczone oraz zgromadzono dużą wiedzę na temat ich efektywności. Pierwsza zasada głosi, że kształtowanie kompetencji społecznych uczniów z niepełnosprawnościami powinno rozpoczynać się wcześnie, a zatem w okresie przedszkolnym i wczesnoszkolnym. Pozwala to zapobiegać narastaniu opóźnień względem dzieci o typowym rozwoju i powstawaniu bariery w budowaniu wzajemnych relacji. Zasada druga sprowadza się do postulatu, by kształtowanie kompetencji społecznych dzieci o zaburzonym rozwoju odbywało się przede wszystkim w zróżnicowanej grupie rówieśniczej, w naturalnym środowisku. Nauczyciele i rodzice muszą zrozumieć, że indywidualna praca specjalistów z pojedynczymi dziećmi daje słabe efekty (Brown, Odom, Conroy 2001). Zadaniem nauczycieli powinno być raczej takie kształtowanie środowiska, które umożliwi zwiększenie udziału wszystkich dzieci w aktywności grupy przedszkolnej i klasy. Zasada trzecia głosi, że najpierw należy stosować oddziaływania ukierunkowane na całą grupę wychowawczą lub klasę szkolną, czyli zmieniać sposób pracy z większą liczbą osób, a dopiero później sięgać po działania skierowane do wybranych uczniów (Odom, McConnell, Chandler 1994). Interwencje dotyczące poszczególnych uczniów mają dwie kluczowe wady. Po pierwsze, zakłócają one możliwość prowadzenia zajęć z całą grupą, stają się czymś szczególnym i z reguły wymagają dodatkowego personelu, co wpływa na zwiększenie kosztów. Po drugie, 
są one stygmatyzujące, dają zarówno odbiorcom tych działań, jak i ich kolegom informację, że niektórzy uczniowie są inni, gorsi.

Zgodnie z tymi zasadami oraz wiedzą na temat mechanizmów nabywania zachowań społecznych tworzy się hierarchiczne typologie programów przeznaczonych do wspomagania rozwoju kompetencji społecznych uczniów z niepełnosprawnością.

Pierwsza grupa programów obejmuje takie organizowanie środowiska zespołu przedszkolnego lub klasy szkolnej, aby zwiększać liczbę okazji do udanych interakcji między dziećmi z niepełnosprawnością i o typowym rozwoju. Działania te opierają się na założeniu, że zwiększanie bliskości sprzyja nawiązywaniu trwalszych relacji i uczeniu się zachowań od lepiej rozwiniętych rówieśników (Jaamison i in. 2012). Zadaniem nauczyciela jest ograniczenie przestrzeni aktywności grup dzieci, stawianie im zadań skłaniających do wspólnego działania, dostarczanie odpowiednich materiałów, które to ułatwią, a także nagradzanie za pożądane zachowania. Wychowawca przedszkolny może na przykład podzielić dzieci na heterogeniczne grupy, wydzielić im przestrzeń i dostarczyć zabawki, które można w pełni wykorzystać tylko we współpracy (jedno dostaje samochód, a drugie garaż itp.). Jeden z najpopularniejszych programów tego typu został opisany dokładnie w książce Joanny Smogorzewskiej i Grzegorza Szumskiego (2015).

Druga grupa programów dotyczy incydentalnego nauczania zachowań społecznych, prowadzonego bez dokładnego planowania. Nauczyciele wykorzystują naturalne sytuacje w przedszkolu lub w szkole do rozwijania pewnych umiejętności u dzieci i do pogłębiania ich wzajemnych kontaktów. Na przykład nauczyciel, widząc, że uczeń z niepełnosprawnością chce dołączyć do zabawy z rówieśnikami, może zachęcić go do odpowiedniego postępowania, zadając pytanie: „Pamiętasz, jak prosimy kolegów, by zechcieli się z nami pobawić?". Tego typu działania nauczycieli nie tylko pobudzają umiejętności społeczne dzieci, ale także tworzą swoisty nacisk na rówieśników bez niepełnosprawności (Brown, Odom, Conroy 2001). Mówiąc o wykorzystywaniu naturalnych sytuacji do rozwijania kompetencji społecznych dzieci z niepełnosprawnością i pogłębiania ich więzi ze sprawnymi rówieśnikami, nie sposób pominąć błędów wychowawczych, które ograniczają tego typu okazje. Zachowania nauczycieli (z badań wynika, że nierzadkie) w rodzaju odsuwania uczniów z niepełnosprawnością od udziału w dyskusjach klasowych czy uniemożliwiania im pełnienia cenionych funkcji 
społecznych, przedstawiania pracy w parach z niepełnosprawnymi kolegami jako przykrego obowiązku, używania określeń niepełnosprawności jako epitetów, z pewnością ograniczają szanse na rozwój kompetencji społecznych uczniów (szerzej: Oleksy, Cabała 2009).

Trzecia grupa programów opiera się na wykorzystaniu kompetentnych społecznie i wrażliwych rówieśników jako nauczycieli umiejętności społecznych dla osób z niepełnosprawnością (Odom i in. 1999). W każdej klasie są uczniowie wyróżniający się społeczną dojrzałością i wrażliwością na problemy innych. Rozwiązania bazujące na mediacji rówieśniczej zakładają, że nauczyciele w sposób szczególny przygotowują takich uczniów do odgrywania roli pośredników, którzy będą wspomagać kolegów z niepełnosprawnością w doskonaleniu ich kompetencji społecznych i intensyfikowaniu kontaktów z rówieśnikami. Umiejętności nabyte przez uczniów sprawnych w trakcie specjalnego treningu są później przez nich wykorzystywane w naturalnych warunkach na terenie szkoły (m.in. w klasie, na stołówce czy na korytarzach podczas przerw), a czasami także poza nią. Przeszkoleni uczniowie mogą włączać kolegów z niepełnosprawnością w działania wspólnot, w których sami uczestniczą.

Ostatnią grupę stanowią, dobrze znane także w Polsce, programy rozwijania kompetencji społecznych w ramach bezpośredniego nauczania przez nauczyciela terapeutę. Mogą mieć one charakter indywidualny lub być realizowane w małych, homogenicznych grupach. Podstawową ich wadą jest to, że są prowadzone poza naturalnym środowiskiem socjalizacyjnym dziecka i nie tworzą okazji do testowania nabytych kompetencji w codziennym życiu. Należy jednak zwrócić uwagę, że w wielu sytuacjach stosowanie takich programów jest niezbędne, gdyż interwencje w warunkach naturalnych są niewystarczające. Uwaga ta dotyczy zwłaszcza uczniów ze skrajnie niskimi umiejętnościami społecznymi i poważnymi barierami w ich nabywaniu (np. osób z autyzmem lub z zaburzeniami zachowania).

W podsumowaniu należy stwierdzić, że rozwijanie kompetencji społecznych uczniów z niepełnosprawnością jest bardzo ważnym zadaniem edukacji włączającej. Są one istotne nie tylko z punktu widzenia integracji tych osób z rówieśnikami, ale także ich przyszłego życia. Istnieje wiele programów dotyczących tego zagadnienia, z których mogą skorzystać nauczyciele i terapeuci zatrudnieni w placówkach włączających. 


\subsubsection{Relacje rówieśnicze - jakie zagrożenia?}

Iwona Chrzanowska

Środowisko szkolne ma wpływ na zachowania uczniów i relacje panujące między nimi. Badania prowadzone nad tymi zagadnieniami pozwoliły wyodrębnić kilka charakterystycznych postaw, jakie mogą przyjmować młodzi ludzie w grupie rówieśniczej (Ekiert-Grabowska 1982; Hurlock 1985), które - mimo upływu czasu od ich zdefiniowania - wydają się nadal aktualne. Pierwsza z nich skupia dzieci akceptowane, czyli takie, które cieszą się uznaniem i sympatią. Są przyjazne i chętne do współpracy. Wpływa to pozytywnie na ich samoocenę, zapewnia poczucie bezpieczeństwa i satysfakcji z nawiązywanych interakcji. Osoby takie odnoszą sukcesy społeczne. Rówieśnicy liczą się z ich zdaniem i chcą przebywać w ich towarzystwie. Postrzegane są jako atrakcyjni partnerzy w aktywnościach zarówno w szkole, jak i poza nią. W wielu kwestiach związanych z życiem klasowym mają decydujący głos (Ekiert-Grabowska 1982, s. 29). Osoby akceptowane łatwo adaptują się do sytuacji. Mają dobre relacje z rówieśnikami, ale często również z osobami dorosłymi (Hurlock 1985, s. 516).

Inną wyodrębnioną grupą są osoby przeciętnie akceptowane. Ich sytuacja społeczna jest raczej korzystna, ale nie są im powierzane najważniejsze funkcje czy zadania. Mają zazwyczaj krąg znajomych, lecz jest on niewielki i niezmienny. Taką pozycję w grupie rówieśniczej określić można jako neutralną, nie daje ona większych profitów, nie przysparza jednak zdecydowanie przykrych doznań (Ekiert-Grabowska 1984, s. 43).

W kolejnej grupie znajdują się osoby o tzw. statusie niezrównoważonym. Przez część rówieśników są one darzone sympatią i uznaniem, inni jednak wyraźnie ich nie akceptują i nie lubią. To sytuacja trudna, 
gdyż uniemożliwia ustabilizowanie się samooceny, tym bardziej wysokiej, dającej wiarę we własne możliwości (Ekiert-Grabowska 1982, s. 29).

Następnie wymieniane są osoby izolowane. Nie mają przyjaciół wśród rówieśników, są ignorowane, nikt ich nie dostrzega. Nie przynależą do żadnej podgrupy (nawet małej), zazwyczaj również nie biorą czynnego udziału w życiu klasy, są na jej marginesie. Odsuwane od reszty są zwykle osoby nieśmiałe, zachowujące się inaczej niż pozostali, pod jakimś względem odróżniające się od nich. Może to być warunkowane własnym wyborem, brakiem zainteresowania interakcją, np. w sytuacji braku wspólnych celów, pasji, preferencji zachowań. Innym wariantem podstaw wyizolowania danej osoby jest niechęć wobec niej, która może być spowodowana zarówno jej postawą, zachowaniem, jak i czynnikami niezależnymi. Nie ma w tym wypadku żadnego znaczenia również to, że chce się ona z grupą identyfikować i do niej przynależeć (Hurlock 1985, s. 512). W rezultacie, niezależnie od tego, do której z podgrup osoba mogłaby być zaliczona, ograniczeniu ulega możliwość nabywania przez nią doświadczeń społecznych i realizowania treningu interakcji (Ekiert-Grabowska 1984, s. 43).

W najmniej korzystnej sytuacji są osoby odrzucane. Nie są akceptowane przez rówieśników i odczuwają ich negatywne nastawienie. Spotykają się z jawną wrogością i niechęcią, a nawet dyskryminacją. Doświadczają złych emocji, prawdopodobnie odczuwają silne zagrożenie wewnętrzne, co może powodować ukształtowanie się u nich poczucia niższości, bycia gorszym, a w konsekwencji doprowadzić do uwewnętrznienia negatywnego wizerunku siebie i własnych możliwości (Ekiert-Grabowska 1982, s. 30). Może to mieć wpływ na kształtowanie się u nich motywacji, samooceny i poczucia przynależności.

Mark R. Leary (2001) twierdzi, że przynależność społeczna jest warunkiem zaspokajania potrzeb życiowych i rozwojowych człowieka. Dlatego w ludzkie życie wpisane jest dążenie do utworzenia i utrzymania przynajmniej minimalnej liczby trwałych i ważnych relacji interpersonalnych. Zdaniem Leary'ego (2001, s. 5), budowanie przynależności jest procesem, którego jednym biegunem jest maksymalne włączenie w relacje interpersonalne, a drugim maksymalne wyłączenie (odrzucenie). Można go przedstawić w postaci swoistego kontinuum:

$\rightarrow$ maksymalne włączenie - inni podejmują wysiłek, aby poznać jednostkę, 
$\rightarrow$ aktywne włączenie - inni otwierają się na jednostkę,

$\rightarrow$ pasywne włączenie - inni pozwalają jednostce włączyć się,

$\rightarrow$ ambiwalencja - inni nie dbają o to, czy jednostka jest włączona, czy wykluczona, są wobec niej obojętni,

$\rightarrow$ pasywne wykluczenie - inni ignorują jednostkę,

$\rightarrow$ aktywne wykluczenie - inni unikają jednostki,

$\rightarrow$ maksymalne wykluczenie - inni fizycznie odrzucają jednostkę, stosują ostracyzm, porzucają lub wydalają jednostkę z grupy.

Nie ma wątpliwości, że niepełnosprawność czy specjalne potrzeby edukacyjne wynikające z innych powodów będą skutkować odmiennym zachowaniem i być może także wyglądem w stosunku do pewnego przyjętego wzorca, co będzie widoczne także w sytuacjach szkolnych i relacjach rówieśniczych.

Nauczyciele są świadomi nietolerancji, jakiej doświadczają uczniowie z niepełnosprawnością w relacjach rówieśniczych. Obserwują oni takie zachowania jak: wyśmiewanie, przedrzeźnianie, przezywanie, popychanie czy szturchanie (Karwowska 2009). Izolacja i odrzucenie osób z niepełnosprawnością w sytuacjach szkolnych nie należą do rzadkości. Potwierdzają to przeprowadzone badania. Wynika z nich, że:

$\rightarrow$ izolacji, a także odrzucenia w relacjach rówieśniczych doświadczają najczęściej dzieci i młodzież z niepełnosprawnością intelektualną (Maciarz 1985; Dyduch 1999; Lipińska-Lokś 2003; Chodkowska 2004; Kornaś 2004). Z badań Aleksandry Maciarz wynika, że dotyczy to odpowiednio: 30\% i 60\% uczniów, Jolanty Lipińskiej-Lokś - 82,4\%, wobec 41,1\% z nich koledzy ujawniają antypatię, dla 29,4\% są oni obojętni (Lipińska-Lokś 2003, s. 252). Maria Chodkowska wymienia grupę ponad $60 \%$ uczniów z niepełnosprawnością intelektualną odrzucanych w relacjach rówieśniczych szkoły ogólnodostępnej, a Dorota Kornaś wskazuje na $80 \%$ osób z głębszą niepełnosprawnością intelektualną pozostających w analogicznej sytuacji;

$\rightarrow$ mniej negatywne postawy dotyczą osób z niepełnosprawnością ruchową (Rudek 2005; Chodkowska 2004), choć i one doświadczają rówieśniczego odtrącenia i życia na marginesie grupy (Szczupał 2009, s. 229), a także z zaburzeniami słuchu (Sakowicz-Boboryko 2003; Maciarz 2005), z chorobą przewlekłą i z zaburzeniami wzroku (Palak 2012). Badania wskazują jednak, 
że 33\% uczniów z ostatniej wymienionej grupy jest izolowanych, a $30 \%$ odrzucanych (Palak 2000);

$\rightarrow$ uczniowie z niepełnosprawnością zajmują zazwyczaj niższą pozycję społeczną w klasie niż ich rówieśnicy bez niepełnosprawności (Bąbka 2003; Janion 1999; 2001; Kulesza 2002; Wiącek 2005). Wskazuje na to również większość zagranicznych opracowań (Szumski 2011, s. 54). Okazuje się, że opinie nauczycieli w tym zakresie są bardziej optymistyczne niż uczniów. Pedagodzy przypisują uczniom z niepełnosprawnością wyższe pozycje w klasie niż wynika to z badań socjometrycznych (Chodkowska 2001, s. 92);

$\rightarrow$ dzieci z niepełnosprawnością często są postrzegane przez swoich rówieśników jako nieatrakcyjni partnerzy zabaw, bywają obiektem drwin (Szczupał 2009, s. 226);

$\rightarrow$ poziom akceptacji niepełnosprawnego rówieśnika wzrasta z wiekiem. Wskaźnik izolacji w klasach początkowych wynosi 38,1\%, w starszych - 31,3\% (Ćwirynkało 2003), 77,1\% młodzieży licealnej uznaje, że osoby z niepełnosprawnością intelektualną (lekką) i ruchową powinny kształcić się w szkołach ogólnodostępnych (Spławiec 2002).

Postrzeganiu osób z niepełnosprawnością przez rówieśników bez dysfunkcji towarzyszą stereotypy, często wynikające z braku wiedzy na temat niepełnosprawności.

$\rightarrow$ Osoby niewidome, zdaniem widzącej młodzieży, mają mniejszą potrzebę kontaktów społecznych, cechuje je bierność i wzmożony samokrytycyzm (Szabała 2012, s. 94).

$\rightarrow$ Niesłyszącym przypisywane są: niezaradność życiowa, niesamodzielność i niezdolność do pracy (Czykwin 2007); głuchota traktowana jest jako nieszczęście, utożsamiana jest z cierpieniem, a nawet chorobą (Korzon 2010, s. 23).

$\rightarrow$ Pod pojęciem niepełnosprawności kryje się najczęściej niepełnosprawność ruchowa (Kijak 2007).

$\rightarrow$ Osoby z zaburzeniami narządu ruchu postrzegane są jako niezaradne i potrzebujące pomocy, zależne od innych, cierpiące, niedołężne, zdeformowane (Hebl, Kleck 2008). Niepełnosprawność tego rodzaju rówieśnicy traktują najczęściej jako przeszkodę (58\%), stratę (29\%), a tylko 5\% utożsamia ją z wartością (w opiniach samych osób niepełnosprawnych wskazania te sięgają 
$22 \%)$. Młodzi ludzie są również przekonani, że niepełnosprawność narządu ruchu ma bardzo negatywny (50\%) i negatywny (17\%) wpływ na przebieg dzieciństwa oraz że bardzo negatywnie $(50 \%)$ i negatywnie $(21 \%)$ będzie oddziaływała na przebieg dorosłości (analogiczne opinie samych osób z niepełnosprawnością to odpowiednio: $17 \%$ i $25 \%$ oraz $16 \%$ i $25 \%$ ) (Bidziński 2007).

$\rightarrow 11 \%$ uczniów szkół ponadpodstawowych (uczestników badań) twierdzi, że niepełnosprawność jest „wolą Boga”, ok. 3\% - że osoby niepełnosprawne są opętane przez szatana (Sołtysiak, Łabuć-Kryska, Budrewicz 1995, s. 208). Piętnastolatkowie w innym badaniu wśród przyczyn niepełnosprawności intelektualnej wymieniali także wielodzietność rodziny i lenistwo (Oszustowicz 1994).

Poważnym problemem $w$ relacjach rówieśniczych są zachowania agresywne. Wyróżnia się kilka typów agresji szkolnej. Z uwagi na charakter tego zjawiska można mówić o agresji reaktywnej i proaktywnej. Ta pierwsza związana jest z wysokim natężeniem gniewu, impulsywnością, dużym napięciem emocjonalnym, i jest sprowokowana. Agresja proaktywna ma charakter planowy i jest niesprowokowana. Celem sprawcy jest uzyskanie korzyści osobistych i uszkodzenie ciała ofiary. Bierze on pod uwagę konsekwencje swojego zachowania (Kirwil 2004).

Uwzględniając formę działania, możemy mówić o różnych rodzajach agresji. Bezpośrednia następuje wtedy, gdy mamy do czynienia z otwartym atakiem na ofiarę. Celem pośredniej nie jest atakowanie, a działanie służące odizolowaniu ofiary, wykluczeniu jej z grupy. Zazwyczaj przybiera ona formę plotki, prowokacji, fałszywego oskarżenia czy manipulacji. Agresja werbalna to taka, w której nie dochodzi do fizycznego kontaktu z ofiarą - oznacza wyzywanie, przezywanie, wyśmiewanie jej. Agresja relacyjna również odbywa się bez fizycznego kontaktu. To celowe działanie na rzecz obniżenia statusu osoby $i$ jej wykluczenia. Inny typ stanowi przymuszanie. Wyraża się przez użycie gróźb, siły, manipulacji w celu zmuszenia ofiary do zrobienia czegoś, na co nie ma ochoty. Wymieniana jest również agresja materialna, która przybiera formę kradzieży, wymuszeń korzyści materialnych (pieniędzy, rzeczy), niszczenia przedmiotów należących do ofiary. Agresja fizyczna to ta, która związana jest $z$ bezpośrednim kontaktem - potrącaniem, popychaniem, pobiciem. Agresja fizyczna groźna różni się od "zwykłej" skutkiem dla ofiary. Ma zdecydowanie poważniejsze konsekwencje, gdyż często wymaga 
interwencji medycznej. W tym typie agresji wykorzystywane mogą być narzędzia (broń lub cokolwiek, co może być za nią uznane). Występuje także agresja cyfrowa, elektroniczna (cyberprzemoc), czyli działanie przemocowe z wykorzystaniem nowych technologii (Pyżalski 2012). Spotkać się można również z przemocą seksualną - agresją dotyczącą tej sfery życia. Do tego rodzaju zachowań zaliczyć można np. podglądanie, podejmowanie zachowań seksualnych wobec ofiary bez jej zgody (Olweus 2007, s. 22; Czapiński 2009; Giza-Poleszczuk, Komendant-Brodowska, Boczko-Dombi 2011; Komendant-Brodowska 2014).

Warto wspomnieć o jeszcze jednym zjawisku, szczególnie niebezpiecznym z punktu widzenia agresji szkolnej, jakim jest dręczenie (bullying). Jest to typ zachowań cechujących się powtarzalnością ataków indywidualnych lub grupowych na osoby relatywnie słabsze (Salmivalli 2010; Olweus 2007; Rigby 2010). Ken Rigby, diagnozując to zjawisko, wskazuje charakterystyczne jego cechy: chęć wyrządzenia krzywdy, przewaga nad ofiarą, celowe krzywdzenie (zastraszanie), działanie uruchamiane bez prowokacji, powtarzalność, uległość (atakowany nie potrafi lub nie chce się bronić), poczucie krzywdy ofiary i przewagi sprawcy (Rigby 2010, s. 31). Zjawisko jest trudne do wychwycenia, gdyż często sprawca podejmuje próby bagatelizowania zajścia, sprowadzenia go do kategorii żartu czy droczenia się. Istotnym elementem, na który należy jednak zwrócić uwagę, jest to, że w wypadku droczenia się istnieje możliwość zamiany ról (czego nie ma przy dręczeniu).

Dręczenie szkolne ma charakter proaktywny. Nie ma tu udziału emocji, jest za to planowanie, dążenie do uzyskania kontroli, uprzywilejowanej pozycji (Sijtsema, Veenstra, Lindenberg, Salmivalli 2009), również wobec świadków, którzy nie stają zazwyczaj w obronie ofiary. Dręczenie jest intencjonalne i nigdy nie dzieje się przez przypadek (Rigby 2010, s. 33). Jedną ze strategii działania jest zastraszenie całej grupy rówieśniczej (Olweus 2007). Badacze wskazują też na szczególnie niebezpieczne skutki tego zjawiska, wychodzące poza relację dręczyciel - dręczony. Ten wariant zachowań agresywnych jest wyjątkowo niebezpieczny z uwagi na zaangażowanie osób postronnych - w procederze dręczenia uczestniczy bowiem znacznie liczniejsza grupa, nie tylko sam sprawca. Są w niej także osoby, które czynnie wspierają napastnika, np. pilnując, by nikt (nauczyciel, uczeń, który chce stanąć w obronie atakowanego) mu nie przeszkodził, ale również takie, które się biernie przyglądają, czerpiąc radość z oglądania przemocy (potencjalni przyszli dręczy- 
ciele). Badacze wyodrębniają też grupę osób wspierających sprawcę, np. przez zagrzewanie do agresji, kibicowanie silniejszemu, wyśmiewanie ofiary (Olweus 2007). Badania wskazują, że zjawisko dręczenia dotyczy kilkunastu procent młodzieży szkolnej (Rigby 2010, s. 40-42). $Z$ analiz prowadzonych przez HBSC (2009/2010) wynika, że ofiarami dręczenia częściej padają chłopcy niż dziewczęta, częściej oni są też agresorami. Porównując wskaźniki w Polsce i średnie dla badania HBSC, stwierdzić można, że nieco większy jest odsetek ofiar dręczenia wśród polskich chłopców, odpowiednio 17\% do 15\% (jedenastolatkowie), $14 \%$ do $13 \%$ (trzynastolatkowie), a niższy w grupie piętnastolatków: $8 \%$ do $10 \%$. Średnia dla HBSC pokazuje niewielką tendencję spadkową liczby osób dręczonych w kolejnych latach: 2001/2002, 2005/2006 i 2009/2010, w Polsce trend jest odwrotny lub wskaźniki utrzymują się na stałym poziomie. Wyniki dla grupy polskich dziewcząt i średnie dla badania HBSC w latach 2009/2010 to odpowiednio: 10\% i $12 \%$ (jedenastolatki), 8\% i 11\% (trzynastolatki) oraz 5\% i 7\% (piętnastolatki). W dwóch pierwszych grupach wiekowych wzrastają wskaźniki dotyczące czynnego udziału w dręczeniu: z $3 \%$ do $5 \%$ oraz z $6 \%$ do $8 \%$. Jedynie w grupie piętnastolatek wskaźnik spada z $7 \%$ do $5 \%$.

Zdecydowanie wyższe są wskaźniki czynnego udziału w dręczeniu wśród polskich chłopców niż dziewcząt. W grupie jedenastolatków to $14 \%$, trzynastolatków $15 \%$ i piętnastolatków $16 \%$. W dwóch ostatnich przypadkach obserwowany jest wyraźny spadek w tym zakresie, odpowiednio z 18\% (w 2001/2002) na 15\% (w 2009/2010) i z 24\% na $16 \%$. Porównując wyniki polskich chłopców do średnich w badaniu HBSC zauważyć należy, że są one zbliżone $w$ dwóch starszych grupach wiekowych, a wyższe u jedenastolatków: $14 \%$ dla polskich chłopców przy $10 \%$ dla średniej w HBSC (Currie, Zanotti, Morgan, Currie, de Looze i in. 2012, s. 191-200). Warto zauważyć w wymiarze oddziaływań pedagogicznych, że przemoc w większym stopniu dotyczy dzieci niż młodzieży. Częściej spotykana jest szkole podstawowej niż w ponadpodstawowej.

$Z$ tego punktu widzenia istotne jest uświadomienie sobie, że relacja pełnosprawny - niepełnosprawny może być zagrożona pojawieniem się zachowań agresywnych, gdyż osoba z niepełnosprawnością wydaje się wpisywać w charakterystykę potencjalnej ofiary przemocy. Wyniki badań dotyczące tej kwestii wskazują ponadto, że:

$\rightarrow$ izolowane dzieci (a dotyczy to, jak wynika z badań, uczniów z niepełnosprawnością w szkole ogólnodostępnej) częściej doświad- 
czają agresji, gdyż niski status społeczny utrudnia im posiadanie przyjaciół czy bliskich kolegów, co czyni je jeszcze bardziej bezbronnymi. Brak przyjaciół i odtrącenie rówieśnicze to czynniki sprzyjające postawie agresywnej wobec osoby, wówczas bowiem agresor mniej ryzykuje (Hodges, Perry 1999 [za: Plichta 2010, s. 5-6]).

$\rightarrow$ Szczególnie łatwym celem ataków wydają się osoby z niepełnosprawnością intelektualną. Określa się je nawet pojęciem "łatwych ofiar", mniejsze jest bowiem ryzyko ujawnienia sprawcy w związku z podważeniem wiarygodności osoby atakowanej czy świadka (Mikrut 2000; Hershkowitz, Lamb, Horowitz [za: Plichta 2010, s. 5]).

$\rightarrow$ W przypadku uczniów z niepełnosprawnością (zwłaszcza intelektualną) w edukacji włączającej należy przynajmniej liczyć się z niebezpieczeństwem pojawienia się dręczenia (bullyingu) relacyjnego (np. ignorowania i namawiania do tego innych, plotkowania, prób ośmieszania, wyśmiewania) (Plichta 2010, s. 7-8).

$\rightarrow$ Osoby z niepełnosprawnością (np. intelektualną) również mogą ujawniać zachowania agresywne. Stwierdzono, że w większym stopniu niż u osób sprawnych wynikają one z namowy, nacisku rówieśników czy chęci zwrócenia na siebie uwagi. Zachowania agresywne mogą być również wynikiem reakcji obronnych w związku z obniżoną zdolnością stosowania innych rozwiązań, a także z mniejszą kontrolą emocji (Mikrut 2000).

$\rightarrow$ Połączenie niepełnosprawności intelektualnej i zachowań agresywnych przyczynia się do wzrostu wskaźników rówieśniczego odrzucenia: $72 \%$ na poziomie szkoły podstawowej, $80,6 \%$ na etapie gimnazjum i 57,9\% w zasadniczej szkole zawodowej. Okazuje się również, że odrzucenie częściej dotyczy chłopców niż dziewcząt z niepełnosprawnością intelektualną (84,2\% do $44 \%$ ) (Żywanowska 2009, s. 199).

Nie ma zbyt wielu badań dotyczących innych grup uczniów ze specjalnymi potrzebami edukacyjnymi w kontekście agresji rówieśniczej. Wskazane wcześniej uwarunkowania podstawy izolowania przywoływane za Dorotą Ekiert-Grabowską czy Elizabeth B. Hurlock pozwalają jednak wnioskować z dużym prawdopodobieństwem, że uczeń ze specjalnymi potrzebami edukacyjnymi wpisuje się w „inność". 


\subsection{Edukacja włączająca w badaniach naukowych - perspektywa rodzica}

Iwona Chrzanowska

Skuteczna edukacja włączająca wymaga zaangażowania rodziców uczniów. Ważne są ich postawy wobec tej idei, a znaczenie ma również ich zaangażowanie w proces edukacji dziecka i współpraca $z$ nauczycielami. $Z$ badań wynika, że większość z nich deklaruje akceptację dla wspólnego kształcenia. Niektórzy rodzice dzieci z niepełnosprawnością wykazują jednak sceptycyzm, zwłaszcza w odniesieniu do kwalifikacji kadry, wyposażenia szkół i wsparcia uczniów. Obawiają się nieprawidłowych relacji z rówieśnikami (izolacji, wykluczenia). Problemem jest także zbyt późna diagnoza zaburzeń rozwojowych.

\section{__ Słowa kluczowe:}

rodzice w edukacji włączającej

oczekiwania 


\subsection{Inclusive education in scientific research - parent's perspective}

Iwona Chrzanowska

Effective inclusive education requires the support of pupils' parents. In this case, parents' attitudes towards inclusive education are important, as are parents' involvement in the child's education process and cooperation with teachers. The research shows that the majority of them declare acceptance of the idea of joint education. Some parents of children with disabilities, however, show some skepticism, especially regarding the qualifications of the staff, system of support, peer relations. The problem is also too late diagnosis of developmental disorders.

\section{Keywords:}




\section{Rodzice wobec edukacji włączającej}

Odnosząc się do tytułowego zagadnienia warto skupić się na kilku wątkach: nastawienia, postaw rodziców wobec idei edukacji włączającej i ich uwarunkowań, zaangażowania rodziców w proces edukacji dzieci, w tym współpracy z przedszkolem i szkołą.

Odwołując się do strukturalnego modelu postaw Lewisa R. Aikena (2002) istotne jest rozpoznanie uwarunkowań powstawania odpowiednich nastawień, z uwzględnieniem trzech komponentów postawy: poznawczego, afektywnego i behawioralnego. Komponent poznawczy to wiedza i przekonania dotyczące przedmiotu postawy. Komponent afektywny odnosi się do uczuć, emocji, a składnik behawioralny koncentruje się na doświadczeniu - to intencjonalne bądź realne zachowania człowieka wobec przedmiotu postawy (np. Eagly, Chaiken 1993; Wojciszke 2000). Szukając warunków kształtowania się postaw, badacze wskazują na zasoby indywidualne i społeczne (Mądrzycki 1997). W kwestii rozpoznawania uwarunkowań kształtowania się postaw osób dorosłych, w tym wypadku rodziców, warto odnieść się zwłaszcza do czynników indywidualnych. Pozwoli to zrozumieć zróżnicowanie postaw, a jednocześnie stosować bardziej świadome i trafne działania, zmierzające do stopniowej zmiany negatywnych nastawień niesprzyjających integracji społecznej.

Jedną z istotnych koncepcji, którą można tutaj przywołać, jest salutogeneza Arrona Antonovsky'ego (1995). Centralnym pojęciem jest w niej „poczucie koherencji” - rozumiane jako zgeneralizowany emocjonalno-poznawczy sposób pojmowania świata, który pozwala na dostrzeganie i odbiór otaczających zjawisk jako zrozumiałych, poddających się kontroli i mających sens, a zatem wartych podejmowania wysiłku oraz inwestowania emocjonalnego. Poczucie koherencji na wysokim poziomie sprzyja radzeniu sobie z realizowaniem zadań życiowych, zaspokajaniu potrzeb i stosowaniu mechanizmów przezwyciężania trudności (m.in. Czabała, Sęk 2000; Pasikowski 2000). Definiowane są trzy wymiary poczucia koherencji, do których zaliczane są: zrozumiałość, zaradność lub sterowalność i sensowność. Poczucie zrozumiałości dotyczy poznawczego aspektu sytuacji. Informacje mogą być postrzegane jako spójne, uporządkowane, ustrukturowane i jasne lub chaotyczne, nieuporządkowane, losowe, przypadkowe bądź niewytłumaczalne (Antonovsky 1995, s. 32). Osoba z silnym poczuciem zrozumiałości będzie w stanie dokonać poznawczej oceny informacji 
(bodźców), nawet jeśli będą one niechciane, niepożądane, zagrażające czy niespodziewane. Będzie w stanie je wyjaśnić (Antonovsky 1997). Osoba zaradna ma poczucie, że poradzi sobie z każdym, nawet niepomyślnym zdarzeniem. W trudnej sytuacji może aktywnie wpływać na sytuację. Umie sama poradzić sobie z trudnością lub wie, do kogo zwrócić się o skuteczną pomoc. Przyjmuje postawę aktywną i próbuje rozwiązać problemy (Antonovsky 1995). Poziom sensowności to wymiar emocjonalno-motywacyjny, wyrażający się zaangażowaniem we własne życie, wiarą w sens działań, wysiłkiem, poświęceniem i zaangażowaniem (Antonovsky 1997). Nie oznacza to, że osoby o wysokim poczuciu koherencji postrzegają cały świat jako zrozumiały, sterowalny i sensowny. Zazwyczaj dotyczy to obszarów istotnych dla ich funkcjonowania.

Już badania Antonovsky'ego (1995) wskazywały, że silne poczucie koherencji cechuje ludzi otwartych na innych i na ich potencjalne problemy. W miarę spadku poczucia koherencji obserwuje się coraz większą tendencję odgradzania się od innych i zamykania w sobie. $Z$ analiz Janusza Kirenki $(2015$, s. 110) wynika z kolei, że osoby o postawie tolerancyjnej uzyskują w badaniach wyższe wyniki w zakresie poczucia koherencji niż osoby dystansujące się. Dotyczy to wszystkich komponentów.

Wyniki prac naukowców nad problematyką nastawienia i postaw wobec edukacji włączającej można przedstawić w dwóch odsłonach - w odniesieniu do rodziców uczniów sprawnych i rodziców uczniów ze specjalnymi potrzebami edukacyjnymi, w tym z niepełnosprawnością.

W Polsce nie ma wielu badań dotyczących opinii rodziców na temat edukacji włączającej, ten temat jest bardziej popularny poza naszymi granicami. Ogólny wniosek z prowadzonych analiz jest taki, że większość rodziców uczniów z niepełnosprawnością i bez niej deklaruje akceptację dla idei wspólnego kształcenia (Grzelak i in. 2014; Marciniak-Paprocka 2017; Hilbert 2014).

Niektórzy rodzice dzieci z niepełnosprawnością lub ze specjalnymi potrzebami edukacyjnymi wykazują jednak pewien sceptycyzm, zwłaszcza w odniesieniu do kwalifikacji kadry i wyposażenia szkół (Bennett, Gallagher 2013). Mówią także o niebezpieczeństwie społecznej izolacji uczniów z niepełnosprawnością w zwykłej klasie szkoły ogólnodostępnej (Leyser, Kirk 2004). Obawy tego rodzaju dostrzec można zwłaszcza w opiniach rodziców dzieci ze znacznym stopniem niepełnosprawności. Nie wyrażają oni poparcia dla idei włączania (Palmer, Fuller, Arora, Nelson 2001), choć i to nie jest normą. Jak poka- 
zują wyniki badań (Gallagher, Floyd, Stafford, Taber i in. 2000), rodzice mogą być zadowoleni z efektów edukacyjnych i korzyści społecznych ze wspólnej nauki, zwłaszcza gdy dziecko uczestniczy w zintegrowanych programach kształcenia od przedszkola po szkołę średnią.

Rodzice dzieci z niepełnosprawnością są pozytywnie nastawieni do przedszkolnej edukacji włączającej. W badaniach Iwony Myśliwczyk (2016) respondenci zwracali uwagę na takie kwestie jak: przebywanie z pełnosprawnymi rówieśnikami jako przygotowanie do funkcjonowania w otwartym środowisku, rozwój kompetencji i możliwość ich nabywania w relacjach z rówieśnikami. Nie do końca interesują ich formalne kwalifikacje nauczycieli, bardziej pozytywne rezultaty ich pracy widoczne w kompetencjach dzieci. Nie wszyscy rodzice są zadowoleni z efektów wspólnego kształcenia czy metod pracy (Twardowski 2009, s. 24).

Wśród głównych powodów wyboru włączających form edukacji w szkołach ogólnodostępnych na poziomie podstawowym wymieniane są: bliskość miejsca zamieszkania, możliwość rozwoju wśród pełnosprawnych rówieśników, najlepsze dopasowanie szkoły do potrzeb dziecka. W wypadku szkół integracyjnych wskazuje się: najlepsze dopasowanie placówki do potrzeb dziecka i możliwość rozwoju wśród pełnosprawnych rówieśników (Grzelak i in. 2014, s. 63). Na poziomie gimnazjum w szkołach ogólnodostępnych są to: możliwość rozwoju wśród pełnosprawnych rówieśników, najlepsze dopasowanie placówki do potrzeb dziecka, bliskość miejsca zamieszkania. W szkołach integracyjnych: rozwój wśród pełnosprawnych rówieśników, najlepsze dopasowanie szkoły do potrzeb dziecka (Grzelak i in. 2014, s. 68). Wybór placówki ogólnodostępnej na etapie ponadgimnazjalnym rodzice motywują: przeświadczeniem o tym, że dziecko nauczy się tam zawodu, rozwinie wśród pełnosprawnych rówieśników, a sama szkoła będzie dostosowana do jego potrzeb i zainteresowań. W przypadku szkół integracyjnych czynnikami motywacyjnymi są: dostosowanie do potrzeb ucznia, przeświadczenie o skuteczności nauki zawodu, szansa na zdobycie pracy (Grzelak i in. 2014, s. 72). We wszystkich tych kategoriach analiz powtarzającym się motywem jest dążenie rodziców do tego, by ich dzieci rozwijały się wśród pełnosprawnych rówieśników. Nie ma zatem wątpliwości, że jest to najsilniejszy motyw, a zarazem najważniejsza kwestia w wyborze ścieżki kształcenia - tym samym uznać można, że rodzice uczniów z zaburzeniami rozwoju i z niepełnosprawnością są zdecydowanymi zwolennikami edukacji włączającej. 
Większość rodziców dzieci bez niepełnosprawności również wspiera koncepcję wspólnego kształcenia: $64 \%$ badanych ujawnia ogólnie pozytywne postawy wobec inkluzji, $26 \%$ neutralne, a $10 \%$ negatywne. Niemniej pojawiają się obawy o to, czy wspólne kształcenie nie spowoduje większej koncentracji nauczyciela na uczniu ze specjalnymi potrzebami, czy nie pojawią się problemy związane z zachowaniem dzieci z niepełnosprawnością. Zdaniem 78\% rodziców uczniów bez niepełnosprawności, wspólne kształcenie nie przyczyni się do wzrostu kompetencji szkolnych ich dzieci, a $22 \%$ sądzi, że przełoży się na spadek indywidualnego kontaktu ich dzieci z nauczycielem. Przeważająca część rodziców pozytywnie ocenia z kolei wpływ praktyk włączających na rozwój emocjonalny: $67 \%$ wskazuje na wzrost akceptacji różnic między ludźmi, dotyczących zachowania i wyglądu, 29\% na zwiększenie samooceny (Peck, Staub, Gallucci, Schwartz 2004). Z badań realizowanych w Polsce wynika, że wśród korzyści z edukacji włączającej rodzice wymieniają również: uczenie się tolerancji i akceptacji $(93,5 \%)$, kształtowanie empatii $(81,7 \%)$, otwieranie się na świat i docenianie różnorodności $(77,4 \%)$, korzyści dla obu grup $(71 \%)$, motywację do lepszej pracy dla nauczyciela (37,6\%). Wśród zagrożeń wymienia się to, że we wspólnym środowisku dzieci z niepełnosprawnością mogą się czuć gorsze $(59,1 \%)$, a także to, że to na nich, a nie na całej klasie, skoncentrowana będzie uwaga (30,1\%) (Marciniak-Paprocka 2017, s. 151).

Ciekawie przedstawiają się na tym tle wyniki badań Zdzisława Kazanowskiego (2011, s. 261) dotyczące reakcji emocjonalnych związanych ze wspólnym kształceniem osób sprawnych i z niepełnosprawnością intelektualną. W pierwszej grupie obserwuje się więcej negatywnych ustosunkowań emocjonalnych. Jednocześnie występują silniejsze pozytywne reakcje związane z segregacyjnym kształceniem. Omawiane badania dotyczyły wpływu zmian pokoleniowych na postawy wobec osób z niepełnosprawnością intelektualną. Respondentami byli rodzice i ich dorastające dzieci (średnia wieku 17,77 roku). Istotne jest, że osoby młode były większymi niż ich rodzice zwolennikami segregacyjnego kształcenia uczniów z niepełnosprawnością intelektualną, co-zdaniem autora badań - jest zagrożeniem dla rozwoju włączającego modelu kształcenia (Kazanowski 2011, s. 261). 


\section{Satysfakcja - jakie uwarunkowania?}

Perspektywa rodzica osoby z niepełnosprawnością lub ze specjalnymi potrzebami edukacyjnymi. Wybór ścieżki kształcenia to jeden z najtrudniejszych momentów $w$ byciu rodzicem dziecka z niepełnosprawnością (Szwed 2012, s. 71). Decyzja w sprawie określonego rodzaju szkoły (specjalnej, integracyjnej, ogólnodostępnej) oznacza nie tylko inną wizję edukacji i jej efektów, ale - jak wskazuje Sylwia Szwed - również inną wizję niepełnosprawności. Przedstawiając perspektywę rodzicielskich refleksji związanych z dokonanym w przeszłości wyborem, ukazuje jednoczesnie charakterystyczne dylematy naukowców i badaczy zagadnienia. Wynikają one z tego, jakie możliwości stworzyła każdego rodzaju szkoła oraz jakie były perspektywy sprostania przez dziecko stawianym wymaganiom. Dla niektórych rodziców szkoła, np. integracyjna, stała się rozwiązaniem otwierającym, podstawą nabycia kompetencji społecznych umożliwiających dziecku samodzielne i niezależne funkcjonowanie. Inni sądzą, że jest to strata czasu. Ich zdaniem szkoda wysiłku na nabywanie nieprzydatnych, zatem i nietrwałych kompetencji związanych np. z przedmiotami nauczania w szkole, przy jednoczesnym braku kształcenia umiejętności podstawowych, umożliwiających samodzielne funkcjonowanie (np. przemieszczania się, realizacji najprostszych potrzeb) bez udziału osób trzecich. Niektórzy rodzice dzieci z niepełnosprawnością są bardzo negatywnie nastawieni do segregacyjnych form kształcenia, padają mocne określenia, porównujące szkołę specjalną z gettem (Szwed 2012). Dla innych jednak jest to miejsce, w którym ich dziecko nabywa umiejętności, ale i cechy osobowe, pozwalające mu planować szczęśliwe życie. Uczniowie niewidomi umiejący się samodzielnie przemieszczać (także poza terenem szkoły) czy osoby niesłyszące, które potrafią czytać z ruchu warg, mają większe szanse na kontynuowanie kształcenia w systemie niesegregacyjnym (i nierzadko z tych szans korzystają). Wydaje się, że współpraca z pedagogiem specjalnym, zwłaszcza w przypadku poważnych zaburzeń rozwoju, jest koniecznym warunkiem osiągnięcia przez taką osobę sukcesu edukacyjnego i życiowego.

Uwarunkowanie I-swoboda wyboru placówkikształcenia. Jakwykazują analizy, zdecydowana większość rodziców dzieci z niepełnosprawnością, wybiera dla nich placówki ogólnodostępne i integracyjne. Na poziomie przedszkola to odpowiednio $79,1 \%$ i 17,2\% (placówki publiczne) oraz 
65,4\% i 25,9\% (niepubliczne) (Grzelak, Kubicki, Orłowska 2014, s. 41). W przypadku szkoły podstawowej pierwszym wyborem jest najczęściej placówka ogólnodostępna (72,3\%), następnie integracyjna (16,7\%) i specjalna (11\%) (Grzelak i in. 2014, s. 47-48).

Około $48 \%$ rodziców dzieci z niepełnosprawnością na poziomie szkoły podstawowej deklaruje, że ma możliwość swobodnego wyboru placówki kształcenia dla dziecka. Najmniej optymistycznie przedstawia się to w małych miastach (do 20 tys. mieszkańców), gdzie przywilej ten ma 36,9\% uczestników badania. Niewiele lepiej jest na terenach wiejskich - 40,9\%. Najkorzystniejsza jest sytuacja w dużych miastach (powyżej 500 tys. mieszkańców), gdzie ponad 65\% rodziców ma swobodę wyboru.

Na etapie gimnazjum możliwość wyboru ma już jedynie $45 \%$ badanych. Najmniej korzystna jest sytuacja rodziców i uczniów z terenów wiejskich oraz z małych miejscowości (odpowiednio: 38,9\% i 41,7\%), najlepsza - w dużych miastach $(61,7 \%)$.

Głównym powodem wyboru placówek ogólnodostępnych i integracyjnych - w opinii rodziców - jest chęć, by dziecko rozwijało się wśród sprawnych rówieśników. Z kolei w przypadku szkoły specjalnej i integracyjnej chodzi o to, by uczyło się wśród innych dzieci z niepełnosprawnością. Okazuje się również, że jeśli wziąć pod uwagę zainteresowania dziecka, na pierwszym miejscu znajduje się szkoła ogólnodostępna, na ostatnim zaś - specjalna (Grzelak i in. 2014, s. 56-57).

\section{Uwarunkowanie II - zbyt późna diagnoza zaburzeń rozwojowych.} Wyniki analiz wskazują, że u ponad $71 \%$ dzieci z lekką niepełnosprawnością intelektualną rozpoznanie problemów rozwojowych następuje po szóstym, a u $26 \%$ - po dziesiątym roku życia. W przypadku niepełnosprawności intelektualnej umiarkowanej i znacznej, które są łatwiejsze do zdiagnozowania, rozpoznanie u $24 \%$ dzieci następuje dopiero po szóstym, a u $5 \%$ - po dziesiątym roku życia. Z kolei $49 \%$ dzieci z zaburzeniami ze spektrum autyzmu (ASD) uzyskuje diagnozę przed szóstym, a 17\% dopiero po dziesiątym roku życia (Grzelak, Kubicki, Orłowska 2014, s. 32-34). Późniejsze wykrycie niepełnosprawności oznacza opóźnienie specjalistycznego wsparcia, często także wczesnego wspomagania rozwoju, kluczowego dla dalszego funkcjonowania. W wielu sytuacjach wiąże się to również z trudnością wyboru właściwej ścieżki kształcenia. Warto przy tym sobie uzmysłowić, że kwestie zbyt 
późnej diagnozy zaburzeń rozwojowych to zagadnienie, które od wielu lat jest podejmowane w badaniach naukowych. Jan Pańczyk już w latach 90. XX w. wskazywał tę kwestię w związku z diagnozą niepełnosprawności (Pańczyk 1990; Głodkowska 1999).

\section{Uwarunkowanie III - relacje między możliwościami przedszkoli i szkół} a potrzebami dzieci. Z badań wynika, że na poziomie przedszkola do innych placówek, decyzją rodziców, przenoszonych jest $13 \%$ dzieci z niepełnosprawnościami, na poziomie szkoły podstawowej-aż 30,5\%. W przypadku przedszkoli najważniejszym z powodów przenoszenia dzieci jest brak możliwości zaspokojenia przez placówkę potrzeb osób z niepełnosprawnością - wskazuje na niego 20\% rodziców (Grzelak i in. 2015, s. 40-42). W przypadku szkół podstawowych najczęstszą przyczyną zmiany jest to, że dziecko nie radziło sobie z wymaganiami szkoły z uwagi na niepełnosprawność, przy czym częściej na ten problem zwracają uwagę rodzice dzieci zabieranych z placówek integracyjnych, a rzadziej z ogólnodostępnych. W przypadku uczniów, dla których wybór szkoły okazał się nieudany, placówką pierwszego wyboru była zwykle szkoła ogólnodostępna (ok. 60\%), rzadziej integracyjna (ponad 30\%) i specjalna (8,8\%). Głównym powodem rezygnacji ze szkoły pierwszego wyboru, wskazywanym przez rodziców, było niedostosowanie szkoły do potrzeb dziecka - 29,4\% (Grzelak i in. 2014, s. 47-48).

Znacznie niższe są wskaźniki zmiany placówki kształcenia w wypadku gimnazjum (dotyczy to ok. 5,4\% uczniów). Zdecydowanie najczęściej dzieje się tak w wypadku ogólnodostępnej (69\%), znacznie rzadziej integracyjnej (16\%). Głównym powodem poszukiwania innej placówki jest, w opiniach rodziców, nieradzenie sobie w szkole z uwagi na niepełnosprawność (40\% szkoła ogólnodostępna, 26,7\% - integracyjna) (Grzelak i in. 2014, s. 65-66). Analizy Instytutu Badań Edukacyjnych potwierdzają prawidłowość, że im dłużej uczeń pozostaje w danej formie kształcenia, tym mniejsze ryzyko, że będzie ją zmieniał (Grzelak i in. 2014, s. 50). Wraz z przechodzeniem na kolejne etapy edukacyjne zmniejsza się liczba uczniów, którzy modyfikują pierwotny wybór placówki. Zauważyć jednak należy, że prawdopodobnie dzieje się tak nie dlatego, że oferowane są w nich lepsze warunki włączania w porównaniu ze szkołami na poziomach poprzedzających, ale w związku z tym, że pozostała w nich młodzież ujawnia potencjalnie najniższy poziom zaburzeń i zakłóceń rozwojowych, mogła sobie zatem poradzić w szkole. 
Inną przyczyną mógł być splot sprzyjających czynników, w tym silne wsparcie rodziny i szkoły.

Uwarunkowanie IV - efektywna współpraca. Warunkiem koniecznym powodzenia działań włączających jest współdziałanie rodziców z nauczycielem (Christenson, Sheridan 2001; Hendersen, Mapp 2002; Twardowski 2012). Dotyczy to zwłaszcza głównych celów kształcenia, zaangażowania i determinacji w działaniu (Carlisle, Stanley, Kemple 2005; Epstein 2001). Rodzice są pierwszymi opiekunami i nauczycielami dziecka. Łączą ich z nim silne relacje, zazwyczaj pozbawione lęku i niepewności, które pojawiają się w kontakcie z osobą spoza rodziny. W wielu wypadkach są także świetnymi specjalistami, rehabilitantami swoich dzieci (Twardowski 2002; McWilliam 2010). Jednym z głównych warunków dobrej współpracy między nauczycielami i rodzicami jest skuteczna komunikacja, a ta ma szanse zaistnieć jedynie wtedy, gdy nie będzie jednostronna (nadawca - nauczyciel, odbiorca - rodzic) (Taylor, Smiley, Richards 2009), skoncentruje się na wymianie informacji (Lee, Low 2013) i będzie oparta na chęci uczenia się od siebie i szacunku. Rodzic nie może być w tej relacji traktowany jako pomocnik nauczyciela/specjalisty czy wykonawca jego poleceń, ale jako równoprawny uczestnik procesu (Twardowski 2012, s. 10). Być może wówczas zmieni się stereotypowy obraz roszczeniowego rodzica ucznia z niepełnosprawnością (Anannikova 2015; Kubicki, Dudzińska, Olcoń-Kubicka 2012; Grzelak i in. 2014).

\section{Uwarunkowanie V - problemy w funkcjonowaniu szkolnym dzieci/uczniów z niepełnosprawnością, specjalnymi potrzebami edu-} kacyjnymi. Głównym powodem zmiany placówki kształcenia jest fakt, że dziecko nie radzi sobie z wymaganiami szkoły z uwagi na występujące zaburzenia, zakłócenia rozwoju. Na etapie szkoły podstawowej z tego powodu przeniesionych do innych rodzajów (typów) szkół zostało: 35,5\% uczniów placówek ogólnodostępnych, 44,2\% integracyjnych i $17,2 \%$ specjalnych, w gimnazjum to odpowiednio: $40 \%, 26,7 \%$ i 23,1\%. Wymagań programowych nie spełnia w szkole podstawowej analogicznie: 10,1\%, 3,5\% i 1,7\% uczniów, w gimnazjum 20\% w przypadku edukacji ogólnodostępnej (Grzelak i in. 2014, s. 48, 66). Część rodziców dzieci z niepełnosprawnością wskazuje również, że powodem zmiany placówki kształcenia były problemy w relacjach z rówieśni- 
kami. Doświadczyło ich $11 \%$ dzieci na etapie edukacji przedszkolnej ${ }^{1}$, $6,1 \%$ na etapie szkoły podstawowej 2 ogólnodostępnej, 5,8\% - integracyjnej i 8,6\% - specjalnej, 7,3\% - w gimnazjum ogólnodostępnym ${ }^{3}$, $20 \%-w$ integracyjnym, 15,4\% - w specjalnym (Grzelak i in. 2014, s. 42,48$)$.

Wyniki przedstawionych tu analiz wskazują na kilka istotnych czynników warunkujących satysfakcję rodziców z wyboru placówki kształcenia. Można je również potraktować szerzej, jako predyktory edukacji włączającej czy nawet wyzwanie związane z kształceniem osób ze specjalnymi potrzebami edukacyjnymi w Polsce. Odnoszą się one pośrednio do kompetencji kadry pedagogicznej, a także warunków kształcenia, wsparcia ucznia oraz nauczyciela w pracy zawodowej. Można byłoby je sprowadzić do wymagania stosowania w ramach działań dydaktycznych projektowania uniwersalnego w zakresie metod lub form organizacyjnych. $Z$ kolei $w$ ramach działań wychowawczych - do umiejętności pracy w grupie zróżnicowanej, budowania dobrego klimatu szkoły, współpracy ze specjalistami i rodzicami, a w sytuacjach koniecznych - uruchamiania programów wychowawczych przeciwdziałających zachowaniom niewłaściwym w relacjach rówieśniczych.

\section{Perspektywa rodzica dziecka sprawnego}

Uwarunkowanie I - deklaratywność postaw i obawa o obniżenie poziomu kształcenia. Rodzice dzieci sprawnych obawiają się, że edukacja włączająca wpłynie na obniżenie poziomu kształcenia. Zakładają, że w sytuacji, gdy w szkole pojawi się uczeń z niepełnosprawnością, z zaburzeniami czy z zakłóceniami w rozwoju, nauczyciel dostosuje do niego proces edukacyjny. Nawet jeśli to nie nastąpi, uważają, że będzie zmuszony poświęcić mu więcej uwagi niż innym osobom w klasie, w tym sprawnym, którzy lepiej radzą sobie z wymaganiami szkoły, czyli potencjalnie nie potrzebują większego wsparcia. Opinie takie związane są poniekąd z oceną szkoły: jej zdolnością do realizacji zadań statutowych i jakością oferowanego kształcenia. Z jednej stro- 
ny wskaźniki badań międzynarodowych odnoszących się do poziomu nauczania w polskich szkołach wskazują na poprawę umiejętności podstawowych uczniów, np. tych dotyczących umiejętności czytania ze zrozumieniem, rozumowania i interpretacji tekstu. Badania OECD PISA pokazują, że w 2000 r. polscy piętnastolatkowie plasowali się poniżej średniej OECD, w 2003 r. osiągnęli średnią, a w 2006 r. znaleźli się powyżej (Federowicz, Sitek 2012, s. 2). Z drugiej strony obecnie coraz więcej uwagi zwraca się nie tyle na wartości wskaźników obiektywnych, ile na efekty w postaci wiadomości, umiejętności i kompetencji rozumianych jako zdolność do stosowania posiadanej wiedzy i umiejętności w różnych sytuacjach: osobistych, społecznych, zawodowych. Ważne jest również uaktualnianie wiedzy i umiejętności, nabywanie nowych kompetencji i kwalifikacji, czyli uczenie się dorosłych. W tym obszarze Polska osiąga jedne z najsłabszych wyników w Unii Europejskiej i OECD (Federowicz, Sitek 2012, s. 2).

Z badań Katarzyny Marciniak-Paprockiej wynika, że 79,5\% rodziców dzieci sprawnych deklaruje aprobujące nastawienie do edukacji włączającej (Marciniak-Paprocka 2017, s. 144), 63,4\% ma pozytywny, a 33,3\% raczej pozytywny stosunek do wspólnego kształcenia i wychowania ich dzieci wspólnie z niepełnosprawnymi rówieśnikami (tamże, s. 150). Dodać należy, że już jedynie 40,9\% jest zdania, iż pomoc psychologiczno-pedagogiczna jest udzielana wszystkim uczniom, a nie jedynie tym ze specjalnymi potrzebami, z niepełnosprawnością. Dodatkowo ok. $20 \%$ rodziców wyraża przekonanie, że nie trafia ona do wszystkich potrzebujących poza osobami z niepełnosprawnością (tamże, s. 151).

Uwarunkowanie II - aspiracje rodziców. Wyniki badań wskazują wysokie aspiracje rodziców wobec wykształcenia swoich dzieci. Ponad połowa $(52,5 \%)$ chce, by ich dziecko uzyskało wykształcenie wyższe magisterskie lub lekarskie, niemal jedna czwarta $(24,1 \%)$ - wyższe licencjackie, inżynierskie, a 11,1\% - przynajmniej stopień naukowy doktora (Kozłowski, Matczak 2012, s. 11), z kolei 40\% rodziców nie jest skłonnych do żadnych ustępstw w tym zakresie, niezależnie od okoliczności (tamże, s. 31). 
Uwarunkowanie III - nierealna wizja szkoły. Co rodzice wiedzą o szkole i postawach swoich dzieci? Z analiz wynika, że rodzice idealizują szkołę i swoje dzieci. Badania „Diagnoza szkolna 2009" Janusza Czapińskiego, zrealizowane w ramach programu społecznego „Szkoła bez przemocy", w części poświęcone zostały rodzicom i ich opiniom na temat przemocy oraz innych problemów polskiej szkoły. Wyniki wskazują duże rozbieżności między zdaniem osób dorosłych a opiniami ich dzieci. W odniesieniu do interesujących nas $w$ tej analizie treści warto przytoczyć kilka wyników badań:

$\rightarrow A z ̇$ 83\% rodziców uważa, że ich dzieci spędzają większość czasu w domu - one jednak dwukrotnie częściej twierdzą, że jest odwrotnie. Około $28 \%$ i $24 \%{ }^{5}$ badanych uczniów szkół podstawowych twierdzi, że więcej czasu spędza poza domem, tego samego zdania jest jedynie $18 \%$ i $16 \%$ rodziców, na etapie gimnazjalnym odsetek ten wynosi: $33 \%$ i $28 \%$ oraz $15 \%$ i $11 \%$, na ponadgimnazjalnym odpowiednio: $43 \%$ i $28 \%$ oraz $15 \%$ i $17 \%$.

$\rightarrow$ Zdaniem rodziców, dzieci spędzają o połowę mniej czasu w internecie, niż same twierdzą (Czapiński 2009, s. 33).

$\rightarrow$ Badania pokazują, że wraz z wiekiem dziecka spada aktywność społeczna. Prawie co drugi uczeń ostatnich klas szkoły podstawowej (wówczas sześcioletniej) deklaruje, że udziela się w wolontariacie (46\%), a zdaniem rodziców - odsetek ten wynosi $62 \%$. Pod koniec szkoły średniej do działalności społecznej przyznaje się co piąty nastolatek (21\%), a według rodziców zajmuje się nią $41 \%$ ich dzieci (Czapiński 2010, s. 35).

$\rightarrow$ Rodzice rzadko lub bardzo rzadko zdają sobie sprawę z tego, że ich dziecko pada ofiarą szkolnej przemocy: $87 \%$ z nich uznało, że problem ten „w ogóle" lub „raczej” nie jest poważny. Tymczasem ok. $30 \%$ dzieci twierdzi, że jest to istotna kwestia w ich szkole. Połowa jedenastolatków mówi o przemocy psychicznej (30\% rodziców), 54\% czternastolatków (jedynie 9\% rodziców), $38 \%$ osiemnastolatków (10\% rodziców). Podobnie jest z przemocą nauczyciela wobec ucznia: $21 \%$ jedenastolatków twierdzi, że w szkole dochodzi do takich zdarzeń, a podobnego zdania jest $9 \%$ rodziców, 38\% osiemnastolatków wskazuje istnienie tego 
problemu - wobec $9 \%$ twierdzących tak rodziców (Czapiński 2010, s. 37-38);

$\rightarrow$ Rodzice są słabo zaangażowani w życie szkoły. Średnio jedna czwarta z nich nie utrzymuje żadnych kontaktów z placówką edukacyjną. Im starsze jest ich dziecko, tym związek ze szkołą jest słabszy. Brak kontaktów ze szkołą deklaruje 13\% rodziców uczniów szkół podstawowych, $25 \%$ na poziomie gimnazjów i $30 \%$ szkół ponadgimnazjalnych. Nawet gdy pojawiają się kłopoty, co piąty rodzic nie komunikuje się ze szkołą, $76 \%$ rodziców deklaruje udział w każdej wywiadówce - dzieci oceniają, że w spotkaniach z nauczycielem uczestniczy jedynie $56 \%$ z nich (Czapiński 2010, s. 39-40). 


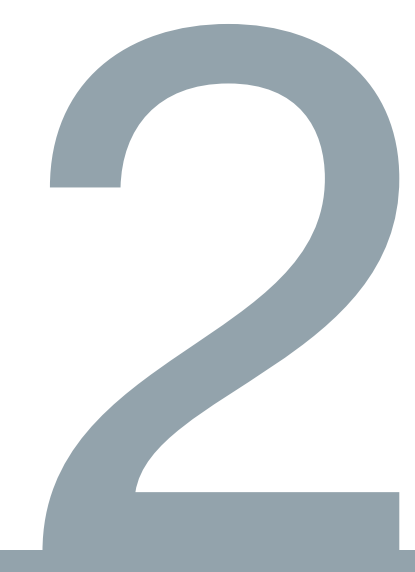




\section{Edukacja włączająca}

w praktyce - czy nowy

model przedszkola/szkoły? 


\subsection{Dostępne przedszkole, dostępna szkoła - co to znaczy?}

Grażyna Małachowska, Marek Tarwacki

Autorzy niniejszego rozdziału - dyrektorzy placówek edukacyjnych - omawiają z perspektywy praktyków kwestie budowania instytucji edukacyjnych dostępnych dla wszystkich, dbających o prawidłowy rozwój wychowanków i dostosowujących się do zmian zachodzących w świecie. Analizują rolę kadry kierowniczej oraz pracowników przedszkola i szkoły w procesie realizacji założeń edukacji włączającej. Wskazują również warunki niezbędne do odniesienia sukcesu przez wszystkich uczniów (strategie rozwoju, plany pracy). 


\subsection{Inclusive preschool, inclusive school - how to understand it?}

Grażyna Małachowska, Marek Tarwacki

The authors of this chapter - directors of educational institutions

- present a practical view on the issue of building educational institutions accessible to all, caring for the proper development of wards and adapting to changes in the world. They analyze the role of the management and employees of kindergarten and school in the process of implementing inclusive education assumptions and indicate the conditions necessary for success of all students (development strategies, work plans).

\section{Keywords:}




\section{Dostępne przedszkole - co to znaczy?}

Zmiany zachodzące we współczesnym świecie, ich wielość i intensywność powodują, że coraz bardziej wpisują się one w codzienność edukacji, warunkują jej rozwój, wskazują na szeroką perspektywę oddziaływań oraz wpływają na jej koloryt społeczny. Wyjście naprzeciw tym zmianom to zadanie dostępnego przedszkola, koncentrującego się na stworzeniu takich warunków, które zapewnią dzieciom sukces przy przekraczaniu kolejnego progu edukacji oraz umożliwią korzystanie z dobrodziejstw otaczającego nas świata, a w konsekwencji osiąganie życiowych celów. Dostępność to przede wszystkim otwartość na różnorodność oraz świadomość jej znaczenia dla rozwoju każdego uczestnika procesu dydaktycznego. Musi być upodmiotowiona, "uczłowieczona”, oparta na empatii, dialogu i współpracy, skierowana na jednostkę oraz na wspólnotę, w której ta jednostka funkcjonuje. Dostępne przedszkole dostosowuje się do dziecka, a nie odwrotnie. Jest to miejsce przyjazne i bezpieczne, oferujące wysokie standardy edukacyjne i moralne, w którym znaczenie mają takie wartości, jak miłość, mądrość i wolność.

Miłość jest bezwarunkowa, zajmuje najważniejsze miejsce w naszym życiu. Oznacza tolerancję, akceptację i poczucie bezpieczeństwa. To także szacunek dla drugiego człowieka, uznanie jego odmiennych wyborów oraz wspieranie podejmowanych działań. Wiąże się również z bezwarunkową gotowością do niesienia pomocy. Mądrość kojarzy się z takimi pojęciami jak: doświadczenie, rozumienie, wiedza. Jest to świadomość siebie i otaczającego nas świata, jego bogactwa i różnorodności, a także potrzeba ciągłego rozwoju, konsekwencja w działaniu. Mądrość pozwala także odróżniać dobro od zła. Wolność to świadomość własnej tożsamości, miejsca w społeczeństwie, prawa do bycia innym, umiejętność dokonywania wyborów oraz ponoszenia za nie odpowiedzialności. Wolność oznacza również możliwość popełniania błędów. Wiąże się z godnością, niezależnością emocjonalną i radością życia. Wszystkie te wartości stanowią o człowieczeństwie „ludzi bogatych wewnętrznie, świadomych w całej pełni odpowiedzialności za czyny i słowa swoje, z wykrystalizowaną wobec zjawisk życia postawą i spiżowym nakazem wewnętrznym" (Grzegorzewska 2002). 
Dostępność jest nierozerwalnie powiązana z włączaniem, począwszy od pierwszego etapu edukacyjnego. W przedszkolu otwartym włączanie jest czymś naturalnym, nie zaś działaniem chaotycznym i pozbawionym reguł. Naturalnym, bo wynika z głębokiego przekonania wszystkich uczestników procesu o słuszności idei inkluzji, z obszernej wiedzy nauczycieli oraz z poczucia odpowiedzialności za każdego wychowanka. Proces ten jest oparty na empatii i konsekwencji. Odpowiednia mentalność, ale także określony sposób myślenia, kultura, charyzma i odwaga - to elementy, które po wdrożeniu w praktykę przedszkolną dają pozytywne rezultaty.

Moje rozumienie edukacji włączającej skupia się na realizowaniu prawa do bycia z innymi, przy jednoczesnym dostrzeganiu własnej odmienności. Często słyszę pytanie: „Ile dzieci w pani przedszkolu jest objętych działaniami włączającymi?", na które odpowiadam krótko: "Wszystkie". Każde bowiem z nich to osobny byt, wymagający szczególnej opieki i wsparcia. Jest to niepowtarzalna indywidualność, niezwykle skomplikowana i tajemnicza, zasługująca na odkrycie i uwagę, mająca takie samo jak inni prawo do edukacji. Wykluczenie jest w każdym z nas, nieświadomie pielęgnujemy je, chociaż nie akceptujemy, boimy się go, ale nie odrzucamy, jest nam bowiem potrzebne do zrozumienia różnorodności. Dlatego bliska jest mi teza, że: „Inkluzja jest czymś więcej niż integracją" (John, Baylis 1994). Jest to przejście od tolerancji do akceptacji, dostrzeżenie w sobie "innego", ale nie „obcego". W edukacji oznacza pełne uczestnictwo dziecka w procesie uczenia się, z uwzględnieniem jego indywidualnej historii oraz specjalnych potrzeb. Włączenie jest więc pojęciem o szerszym znaczeniu niż integracja-działaniem perspektywicznym i systematycznym, skierowanym na dziecko, a nie na program, wymagającym nowego spojrzenia na współczesne przedszkole. Żeby mogło się ono dokonywać, "szkoła jako całość musi się zmieniać w taki sposób, by zapewniała dostęp do pełnego zakresu szans edukacyjnych i społecznych wszystkim uczniom" (Mittler 2000).

Podsumowując, dostępność to "wrota do włączania”, to świadomość i akceptacja różnorodności, która jest istotą naszej tożsamości. Bycie „innym” i wśród „innych" to sedno naszej egzystencji, droga do poznania prawdy o sobie samym. „Inny" jest więc nam niezbędny do istnienia. Takie przesłanie powinniśmy przekazać dzieciom, zarówno poprzez własną postawę, jak i przez konkretne działania edukacyjne. 


\section{Dostępna szkoła - co to znaczy?}

Obecnie szkoła funkcjonuje $w$ dynamicznie zmieniającej się rzeczywistości, co ma związek nie tylko z procesem wprowadzania reform. Staje się ona miejscem, gdzie spotykają się różne oczekiwania, zarówno zewnętrzne, jak i wewnętrzne. Istotną rolę w osiągnięciu lepszych wyników i warunków nauki odgrywają zmiany, jakie zachodzą wewnątrz placówki. Ta, która jest świadoma swojego potencjału, staje się samoczynnie "bąblem zmiany" (Dudzikowska 2001, s. 137-138). Dostępność i otwartość oznaczają prowadzenie szerokiego dialogu przez wszystkie strony społeczności szkolnej, a także ciągłe dokształcanie się i doskonalenie umiejętności w zakresie zarządzania i edukowania. Szkoła powinna być kojarzona z tym, co najlepsze: profesjonalizmem w nauczaniu, rodzinną atmosferą, bezpieczeństwem, tolerancją. W centrum uwagi i wszelkich działań musi znajdować się dziecko z jego potrzebami i oczekiwaniami. Skoro w społeczeństwie coraz bardziej zaczyna się liczyć inicjatywa, odpowiedzialność, samorealizacja, to szkoła powinna wszechstronnie przygotować wychowanków do dorosłego życia. Edukacja włączająca daje równe szanse wszystkim uczniom w procesie nauczania i wychowania, zmierzając do pełnej dostępności. W takiej szkole jest miejsce na wielkie poszukiwania, eksperymenty i samodzielną pracę badawczą. Dzięki temu placówka znajdzie się bliżej uczniów, zapewniając im wysoki poziom nauczania i wychowania, propagując samorządność i postawy twórcze, dbając o każdego podopiecznego i jego wszechstronny rozwój. Dostępność to "oferta" wychowawcza szkoły, rodziców i innych osób dorosłych, powinna być więc najwyższej jakości: atrakcyjna, pełna radości, niosąca głęboką prawdę o życiu. Niczego, co piękne i wartościowe, nie może w niej zabraknąć. Oznacza możliwość przebywania, kształcenia się, wychowywania w miejscu, do którego uczęszczają siostra, brat, przyjaciel oraz rówieśnicy z sąsiedztwa. Placówka dostępna zapewnia uczniom wszechstronną edukację i bezpieczeństwo, jej zasadami są perfekcjonizm i sumienność, ciągłe kształcenie i dokształcanie, konsekwencja w działaniu. Podejmowane w szkole działania są spójne i skuteczne, zaspokajają potrzeby wszystkich uczestników procesu edukacyjnego. Uczniowie dostają równe szanse, co wynika ze zrozumienia jednostkowych potrzeb każdego $z$ nich. Dzięki temu następuje zmiana w wielu obszarach funkcjonowania szkoły: w procesie uczenia się, nauczania, wychowania, a także we wzajemnych relacjach na linii nauczyciel - uczeń, nauczyciel 
- rodzic. W placówce włączającej żadne dziecko nie jest odizolowane od swojego naturalnego środowiska. Korzysta z bogactwa relacji, emocji komunikowania się, przyswajania wartości, naśladowania wzorcowych zachowań. Szkoła dostępna to także nauczyciele, którzy mają możliwość osobistego i zawodowego rozwoju w zakresie wykorzystywania różnych form i metod nauczania, tworzenia indywidualnych planów i programów edukacyjnych oraz wdrażania pracy zespołowej.

\section{Dyrektor przedszkola jako lider zarządzania różnorodnością}

Struktura organizacyjna i funkcjonowanie przedszkola są zdeterminowane przez różnorodne czynniki, zarówno zewnętrzne, jak i wewnętrzne, m.in. położenie, otoczenie kulturowe, środowisko lokalne i możliwości współpracy z nim, bazę i jej zasoby (w tym personel), społeczności wychowanków i ich rodziny. "Zarządzanie różnorodnością jest elementem tworzenia kapitału intelektualnego organizacji, ponieważ ludzie wykorzystują w swojej pracy ważne dla organizacji zasoby niematerialne: wiedzę, kompetencje, zdolności i doświadczenie" (Walczak 2011, s. 16). Dla dyrektora - przywódcy edukacyjnego - jest to nie lada wyzwanie oraz ogromna odpowiedzialność, z czego powinien zdawać sobie sprawę, przyjmując rolę lidera. Świadomość różnorodności, jej znaczenia w rozwoju człowieka, odpowiedzialność za każdy byt tworzący społeczność przedszkolną oraz dążenie do wysokiej jakości edukacji to pierwszy krok ku partycypacyjnemu modelowi zarządzania. Partycypacja to proces służący budowie przedszkola włączającego, dostępnego, opartego na ludziach, ich potencjale osobowościowym i intelektualnym, wzajemnym zaufaniu oraz chęci ciągłego uczenia się. Oznacza pełną identyfikację z misją i wizją placówki, współpracę, uczestniczenie i współdecydowanie, odpowiedzialność oraz refleksję wszystkich członków wspólnoty, w centrum której jest dziecko. Uwzględnia także zarządzanie przez wartości, świadomość ich źródeł oraz ich implementację na grunt społeczności przedszkolnej. Dzięki takiemu podejściu budowana jest wyjątkowość placówki, jej marka i pozycja w środowisku lokalnym. Nie chodzi tutaj o rankingi i niezdrową rywalizację, lecz o wysokie standardy edukacyjne, które dotyczą każdej jednostki, wszystkich członków zespołu i całej grupy.

Zarządzanie różnorodnością jest jednoznaczne $z$ akceptacją tej idei i funkcjonowaniem w niej. Oznacza tworzenie miejsca bezpiecznego, odpowiadającego potrzebom wszystkich dzieci, także tych, które są 
szczególnie narażone na wykluczenie i marginalizację, w tym: niepełnosprawne, z doświadczeniem migracji, z zaburzonym zachowaniem, ofiary przemocy, sieroctwa, ubóstwa lub przewlekle chore (np. z cukrzycą, padaczką, zespołem FAS, nowotworami).

Nie można zapominać także o tym, że dyrektor-lider jest jednocześnie wychowawcą oraz nauczycielem, a także inspiratorem i koordynatorem procesu wychowawczego, dydaktycznego i opiekuńczego. Trudno wyobrazić sobie dobrego dyrektora, który nie pielęgnuje w sobie wartości humanistycznych, człowieczeństwa, który nie uczestniczy w ciągłym procesie uczenia się, który zachęca do innowacji, nie będąc innowatorem, lansuje postęp pedagogiczny, choć sam się nie doskonali, wymaga od innych, ale nie od siebie. Ważne jest również, by jego myślenie o przedszkolu miało charakter perspektywiczny, aby zawierało gen kontynuacji, bo tylko takie podejście pozwala na zbudowanie placówki „długowiecznej”.

To przez partycypację, mentoring, działania menadżerskie, kreatywną postawę i otwartość na wszelkie nowatorstwo, dyrektor-lider może stworzyć „przedszkole dostępne”, nowoczesne i bezpieczne, którego atutem są nie tylko szczęśliwe, samodzielne, twórcze dzieci czy zadowoleni rodzice, ale także wyspecjalizowana, kompetentna oraz zmotywowana do działania kadra.

\section{Dyrektor szkoły jako lider zarządzania różnorodnością}

Dyrektor, jako lider zarządzający różnorodnością, powinien być wzorcem nauczyciela i wychowawcy. Musi dbać szczególnie o przełamywanie bariery na linii nauczyciel - uczeń, nauczyciel - dyrektor, dyrektor - rodzic. Więzi między tymi osobami decydują o jakości procesu kształcenia i wychowania (Kwiatkowski 2010, s. 15-19). Różnorodność to podstawa budowania prawidłowych zachowań oraz eksponowania wartości edukacyjnych i wychowawczych.

Przywództwo w edukacji wpisuje się idealnie w trzy podstawowe komponenty więzi moralnej: zaufanie, lojalność, solidarność (Sztompka 2004, s. 187).

Zadaniem lidera jest tworzenie odpowiednich warunków, aby placówka robiła postępy w integracji społecznej, dydaktyce i wychowaniu. Powinien on dążyć do zacieśnienia współpracy w procesie planowania, monitorowania działań oraz finansowania między wszystkimi podmiotami mającymi bezpośredni wpływ na funkcjonowanie szkoły. 
Kadra, którą zarządza, powinna mieć możliwość kształcenia i samokształcenia umiejętności wykorzystywania form i metod nauczania, tworzenia indywidualnych planów i programów edukacyjnych, a także zespołowej pracy (Tarwacki 2015, s. 2). Sprzyja to osobistemu podejściu do ucznia, do oceny jego możliwości, a także wzmocnieniu uzdolnień. Dostrzeganie mocnych i słabych stron ucznia umożliwia pełne włączanie go w system edukacyjny. W placówce powołuje się zespoły, w skład których wchodzą wychowawcy nadzorujący cały proces dydaktyczno-wychowawczy, oraz zespoły specjalistów, których zadaniem jest realizacja zaleceń zapisanych w orzeczeniach i opiniach poradni psychologiczno-pedagogicznych, jak również pomaganie nauczycielom (dydaktykom) w bezpośredniej pracy z uczniem.

Lider szkolny czuwa nad całościowym wdrażaniem pomocy specjalistycznej oraz dydaktyczno-wychowawczej. Dostrzega potrzebę osiągnięcia nowej jakości przez współpracę z samorządem lokalnym i organizacjami pozarządowymi. Staje się przywódcą w procesie budowania partnerstwa i pozyskiwania środków zewnętrznych. Ta część funkcjonowania placówki daje nowe przestrzenie i możliwości kontynuacji rozpoczętych przez nią projektów. Działania dyrektora jako lidera umożliwiają szersze otwarcie szkoły - aby była nie tylko instytucją przekazującą wiedzę, analizującą zestawienia i wyniki punktowe, ale również miejscem, w którym wsparcie otrzyma każdy uczeń (także taki, który w żadnych rankingach nie jest uwzględniany).

Dobrym liderem jest dyrektor, który wprowadza do procesu nauczania nowe idee: planowanie lekcji uwzględniających różne potrzeby uczniów, rozwijanie umiejętności dostrzegania i rozumienia różnic, angażowanie uczniów w samodzielne uczenie się, obserwację lekcji i zajęć specjalistycznych, poszukiwanie odpowiednich zadań, z którymi muszą zmierzyć się uczniowie, kształcenie umiejętności współpracy. Dyrektor musi mieć przekonanie, że im wcześniej wesprze się dziecko ze specjalnymi potrzebami, tym większe jest prawdopodobieństwo osiągnięcia sukcesu edukacyjnego.

Wsparcie powinno być całościowe - obejmować nie tylko ucznia, ale także jego rodzinę. Rodzic jest pierwszym "terapeutą" swojego dziecka, dlatego ważne jest, aby został dokładnie wysłuchany i potraktowany jako osoba niezbędna w procesie kształcenia. Mówiąc o uczniu ze specjalnymi potrzebami, dyrektor-lider pamięta również o jednostkach wybitnie utalentowanych. Wymaga to od szkoły za- 
stosowania dodatkowych narzędzi, tzn. odpowiednich metod i form pracy, zajęć dodatkowych, pomocy asystenta, właściwych pomocy dydaktycznych i technicznych. Pod kierownictwem lidera, który jest pasjonatem, szkoła dąży do wspierania rozwoju każdego dziecka, biorąc pod uwagę wszystkie aspekty tego procesu: emocjonalny, poznawczy, twórczy, społeczny, fizyczny, moralny. Uczniowie są traktowani indywidualnie. Jedni wymagają większego wsparcia emocjonalnego, kolejnym potrzebna jest pomoc w nauce czy dostosowanie materiału do ich możliwości, a inni wymagają odpowiedniego sprzętu technicznego i konkretnej infrastruktury: aparatów słuchowych, programów do powiększania tekstu, ułatwień architektonicznych.

Zadaniem dyrektora jest rozpoznanie tych potrzeb i wspieranie działań służących ich zaspokojeniu. W proces ten angażuje całą kadrę pedagogiczną, czyli nie tylko specjalistów, ale także nauczycieli poszczególnych przedmiotów i wychowawców. Jest to stała współpraca, w ramach której wszyscy biorą odpowiedzialność za każde dziecko w klasie. Dyrektor stara się patrzeć na swoich uczniów twórczo i konstruktywnie. Rozważa, co należy zmienić w metodach, wymaganiach w pracy, aby wyeliminować niepowodzenia ucznia i znaleźć sposoby na naprawę sytuacji. Dzieli się spostrzeżeniami dotyczącymi postępów danego podopiecznego - co zwiększa otwartość, chęć współpracy i wzajemne wspieranie się kadry szkolnej i uczniów w osiąganiu celów edukacyjnych i wychowawczych. Warto w tym miejscu zauważyć różnicę między zaufaniem do poziomu dydaktycznego szkoły, a zaufaniem do kształtowanego w niej systemu wartości (Szymański 1998, s. 9-10). Placówka pod kierownictwem dyrektora-lidera nie jest zawieszona w próżni - współpracuje $z$ instytucjami lub z organizacjami pozarządowymi w celu podniesienia jakości pracy. Sprzyja to trafnej identyfikacji potrzeb społecznych.

\section{Strategie rozwoju przedszkola}

Tworzenie strategii rozwoju przedszkola dostępnego, ukierunkowanej na "włączanie", wymaga od dyrektora świadomości ciągłości tego procesu, elastyczności, gotowości do zmian (niejednokrotnie pojawiających się „tu i teraz"). Świadomość, jak już wcześniej wspominaliśmy, musi być osadzona w wartościach, które są absolutnymi determinantami myślenia strategicznego. Patrząc w przyszłość, nie można negować przeszłości - trzeba korzystać z tego, co się sprawdziło, a jednocześnie 
uwzględniać nowe perspektywy rozwojowe. Dynamika współczesnej cywilizacji i jej rosnąca złożoność wymagają od nas wykorzystania nowych zasobów oraz ciągłego uczenia się. Te elementy są niezbędne do rozumienia i odczytywania zmieniających się warunków życia, umożliwiają także sprostanie nowym wyzwaniom. Pozwalają na budowanie placówki „długowiecznej”, o wyraźnej tożsamości (tutaj: przedszkola włączającego). Dzięki takim zasobom można z dużym prawdopodobieństwem określić miejsce, w którym za kilka lat znajdzie się przedszkole. Taka wizja wymusza zaplanowanie sekwencji działań umożliwiających osiągnięcie zdefiniowanego celu. Dlatego efektywna strategia (koncepcja) powinna być budowana na podstawie przejrzystych, znanych całej społeczności przedszkolnej, zasad. Są to m.in.:

$\rightarrow$ partnerstwo/partycypacja (myślenie strategiczne, diagnoza, współdziałanie),

$\rightarrow$ dynamiczność (powiązana z kreatywnością i otwartością na zmiany, uwzględnia zewnętrzne szanse),

$\rightarrow$ kontynuacja (czerpanie $z$ dobrych praktyk przedszkola oraz strategii innych podmiotów, także międzynarodowych),

$\rightarrow$ celowość i hierarchiczność (ustalenie priorytetów, celów, zadań),

$\rightarrow$ systematyczna weryfikacja (monitoring strategiczny, bieżąca aktualizacja, ewaluacja),

$\rightarrow$ działania strategiczne ("działania w drodze”, wdrażanie zadań, osiąganie celów).

Tworzenie strategii/koncepcji musi być oparte na dialogu, wnikliwie przemyślane i zaplanowane w czasie, a poszczególne fazy realizacji powinny być zhierarchizowane. Poniżej przykładowe etapy planowania strategicznego obowiązujące w przedszkolu, którym kieruję:

$\rightarrow$ planowanie wstępne (m.in. powołanie zespołu do spraw koncepcji/strategii, ustalenie harmonogramu działań i sposobu przekazywania informacji w trakcie ich realizacji),

$\rightarrow$ analiza/diagnoza potrzeb (środowisko wewnętrzne, lokalne, zewnętrzne źródła informacji),

$\rightarrow$ badanie posiadanych zasobów wewnętrznych (dzieci, nauczyciele, specjaliści, pozostały personel, rodzice, sprzymierzeńcy, organizacja, finanse, zaplecze dydaktyczne),

$\rightarrow$ badanie zasobów zewnętrznych: lokalnych, ogólnopolskich, europejskich (władze oświatowe, urząd miasta, urząd gminy, 
przedszkola i szkoły podstawowe, obiekty przyrodnicze, teatry, kina, muzea, biblioteki, poradnie psychologiczno-pedagogiczne, uczelnie, fundacje, stowarzyszenia, służby mundurowe, lokalne programy na rzecz edukacji, inicjatywy międzynarodowe, np. Erasmus+),

$\rightarrow$ sformułowanie misji (jest to swoista obietnica, zespół wartości, filozofia - fundament istnienia przedszkola),

$\rightarrow$ sformułowanie wizji (pozytywny, perspektywiczny obraz przedszkola, wielu konkretnych inicjatyw i działań, które uświadamiają społeczności przedszkolnej, przez jakie etapy trzeba przejść - służy ona realizacji misji),

$\rightarrow$ określenie kierunków działań oraz celów strategicznych,

$\rightarrow$ opracowanie planu operacyjnego (roczna lub maksymalnie dwuletnia koncepcja pracy placówki, uwzględnia również przygotowanie i realizację programów wspomagania),

$\rightarrow$ wdrażanie strategii,

$\rightarrow$ monitoring i ewaluacja.

Określenie zarysu rozwojowego przedszkola należy do dyrektora-lidera, to od jego wizji zaczyna się strategia. Z reguły pojawia się już w koncepcji kierowania placówką prezentowanej przez kandydata podczas konkursu. Dalej jest ciężka praca całej społeczności przedszkolnej (włącznie z liderem). Strategia jest podstawą istnienia nowoczesnej placówki - zorientowanej na przyszłość, opartej na wartościach i otwartej na różnorodność.

\section{Strategie rozwoju szkoły}

Tworząc strategie rozwoju szkoły trzeba myśleć o placówce nowoczesnej, prezentującej wysoki poziom nauczania i wychowania. Jej dewizą ma być bezpieczeństwo, tolerancja, odkrywanie sensu uczenia się, kreowanie pozytywnych wzorców do naśladowania, aktywny udział w życiu środowiska lokalnego. Celem jest wychowanie człowieka otwartego, odpowiedzialnego za siebie i innych, wrażliwego, kulturalnego i szlachetnego.

„Szkoła nie poddaje się planistom bezwarunkowo" (Warnken 1997, s. 75), dlatego w koncepcjach jej rozwoju znajduje się miejsce na poszukiwania, eksperymenty, projekty i samodzielną pracę badawczą. Takie pomysły mogą być realizowane przez zespół ludzi, którzy są otwarci na kolejne innowacyjne inicjatywy na lekcjach i poza nimi. Dobrym przy- 
kładem może być przyjmowane założenie, „że działanie nauczyciela na rzecz zmiany ( $w$ tym również zmiany rozwojowej ucznia) jest tym skuteczniejsze, im bardziej nauczyciel sam podlega procesom rozwojowym, im bardziej jest świadomy siebie, a także świadomy realizacji przez szkołę jego własnych potrzeb zawodowych (poznawczych, sprawnościowych), a także egzystencjalnych (np. uzyskania uznania, autonomii)" (Kwiatkowska 1997, s. 52). Bardzo dużą rolę w kreowaniu takich postaw odgrywają poczynania dyrektora, który w ramach sprawowanego nadzoru pedagogicznego pobudza różne formy aktywności nauczycieli i pracowników szkoły: ich samodoskonalenie zawodowe, samokształcenie, podnoszenie kwalifikacji oraz uzyskiwanie stopni awansu zawodowego, współpracę w ramach zespołów, lekcje koleżeńskie, tworzenie programów autorskich i stosowanie innowacji pedagogicznych.

Dyrektor ma do zrealizowania konkretne zadania w tym zakresie:

$\rightarrow$ stworzenie planu nauczania na dany rok szkolny, zawierającego: optymalny podział godzin w każdym cyklu edukacyjnym, racjonalny przydział godzinowy zgodny z kwalifikacjami nauczycieli, bezpieczne i higieniczne warunki pracy oraz nauki,

$\rightarrow$ diagnozowanie lokalnych potrzeb edukacyjnych (katalog miejsc, zjawisk i osób, które można wykorzystać edukacyjnie),

$\rightarrow$ analizowanie możliwości, jakie dają programy nauczania,

$\rightarrow$ diagnozowanie wymagań uczniów ze specjalnymi potrzebami edukacyjnymi,

$\rightarrow$ umożliwienie podnoszenia umiejętności nauczycieli w ramach realizacji edukacji włączającej,

$\rightarrow$ ćwiczenie i wykorzystywanie umiejętności pracy zespołowej w codziennej praktyce szkolnej,

$\rightarrow$ zapewnienie prawidłowego przygotowania uczniów do egzaminu lub sprawdzianu,

$\rightarrow$ analizowanie potrzeb środowiska lokalnego w sferze edukacji, wychowania i kultury,

$\rightarrow$ kształcenie umiejętności związanych z poszerzeniem własnego warsztatu pracy.

Tworzenie strategii rozwoju szkoły musi opierać się na prowadzeniu dialogu, możliwie najbardziej szerokiego. Dialog nie może istnieć bez pokory, wiary w możliwość budowania i przebudowywania świata (Frerie 1993, s. 69-73). 
Rezultatami realizacji zadań związanych z rozwojem szkoły powinny być:

$\rightarrow$ porozumienie, współdziałanie, kompromis trzech podmiotów - uczniów, nauczycieli i rodziców - w dziele tworzenia systemu edukacji i rozwijania samorządności na terenie szkoły,

$\rightarrow$ rozwój jakościowy, czyli osiąganie lepszych wyników edukacyjnych,

$\rightarrow$ rozwój programowy, czyli poszerzenie oferty szkoły,

$\rightarrow$ rozwój osobowy kadry pedagogicznej, administracyjnej i obsługowej,

$\rightarrow$ rozwój bazy materialno-technicznej,

$\rightarrow$ współpraca ze środowiskiem lokalnym i z innymi szkołami,

$\rightarrow$ współpraca $z$ instytucjami i stowarzyszeniami w celu pozyskiwania środków zewnętrznych,

$\rightarrow$ współpraca z władzami gminy i powiatu,

$\rightarrow$ dobrze skonstruowany plan nadzoru pedagogicznego i roczny plan pracy szkoły.

Myśląc o tworzeniu strategii placówki, musimy pamiętać, że jesteśmy ciągle w drodze. "Uczące się szkoły" są zdolne do zmiany, do nieustającego rozwoju, po to, by sprostać nowym wymaganiom pojawiającym się w szybko zmieniającym się społeczeństwie, zatem nie uczą się w nich tylko uczniowie, lecz cała społeczność szkolna (Hidebrandt 2001, s. 62).

\section{Planowanie pracy przedszkola}

Opracowując strategię przedszkola otwartego (inkluzyjnego), trzeba uświadomić sobie rolę i znaczenie planu pracy - tzw. planu bieżącego. Zawiera on określone zadania powierzone konkretnym osobom do realizacji w ustalonych terminach. Jest on uszczegółowieniem koncepcji, gwarantem osiągnięcia założonych priorytetów, drogą dojścia do celu. Plan nie może być konstrukcją zamkniętą, ale powinien być elastyczny i otwarty na zmiany, co w konsekwencji będzie miało przełożenie na jego wdrażanie i skuteczność. Ważne jest również, aby zawierał wszystkie obszary pracy przedszkola - od modułu wychowawczego i dydaktycznego po organizacyjno-finansowy. Optymalny czas jego realizacji wynosi rok lub dwa lata. Plan bieżący przedszkola jest uzupełniony o plany operacyjne, dotyczące niektórych działań, np. współpracy $z$ rejonową szkołą podstawową. $Z$ reguły przyjmuje on formę harmonogramu, uwzględniającego ustalenia obu stron. 
W mojej ocenie struktura planu pracy placówki, której jestem dyrektorem, wypełnia definicję "planu bieżącego" oraz służy realizacji koncepcji przedszkola ukierunkowanego na inkluzję. Takie planowanie pozwala usystematyzować działania i uzyskać ich pełną przejrzystość. Umożliwia również natychmiastową identyfikację zagrożeń, zarówno przeze mnie, jak i przez pozostałych członków zespołu.

Jako dyrektor mam świadomość, że wszystkie nasze działania, niepowodzenia, sukcesy są wypadkową różnorodności - tworzymy społeczność niejednorodną pod względem wykształcenia, wieku i doświadczenia. Mamy różne pasje i zamiłowania. Naszym światopoglądom niejednokrotnie nie jest ze sobą "po drodze”. Spieramy się w wielu kwestiach, ale w wielu też się zgadzamy - jesteśmy zespołem, który może na sobie polegać, grupą uczącą się, o wysokich kwalifikacjach, reagującą na potrzeby "tu i teraz". Przykładem może być udział kadry pedagogicznej w kursie języka migowego, gdy pojawiło się u nas dziecko z bardzo dużym uszkodzeniem słuchu. Utożsamiamy się z misją i wizją placówki, które wspólnie wypracowaliśmy i które są naszym drogowskazem. Jesteśmy „przedszkolem daltońskim”, otwartym na każdą indywidualność oraz na wspólnotę, do której należy. Pracujemy w oddziałach zróżnicowanych wiekowo (od trzech do sześciu lat), do których uczęszczają dzieci z grup defaworyzowanych, m.in. z niepełnosprawnościami i ciężkimi chorobami: nowotworami, cukrzycą, z deficytem LCHAD (niedobór dehydrogenazy długołańcuchowych kwasów tłuszczowych), padaczką, astmą lekooporną, zespołem NBS1, chorobami serca, alkoholowym zespołem płodowym FAS, a także doświadczeniem migracji, z zaburzeniami zachowania oraz pochodzące z rodzin niepełnych. Zmieniliśmy sposób i organizację żywienia w przedszkolu - otworzyliśmy się na różnorodne jadłospisy, pozyskaliśmy do współpracy dietetyka. W ramach opieki specjalistycznej zatrudnieni są: logopeda, terapeuta i choreoterapeuta. Ich wszechstronna wiedza, doświadczenie, kreatywność i oddanie dzieciom są bezcenne w procesie włączania.

Kiedy zastanawiam się, co doprowadziło nas do tego miejsca, w którym jesteśmy, na myśl przychodzi mi tylko jedna odpowiedź - ludzie, ich wrażliwość, empatia, inteligencja, konsekwencja i odpowiedzialność. A także, a może przede wszystkim, ich umiejętność współpracy w zespole. Choć nadal jesteśmy w połowie drogi, ważne, że pokonujemy ją wspólnie. 
Na zakończenie przytoczę słowa, które stały się dla mnie podstawą "bycia nauczycielem i dyrektorem", wyznacznikiem mojego człowieczeństwa. Dały mi ogromną siłę do działania, jednocześnie uświadamiając, jak bardzo jestem niedoskonała. " «Inny» tak jak dzieło sztuki zaprasza mnie do zobaczenia świata $w$ innej perspektywie, do zobaczenia siebie jakby w innym świecie. Spotkanie z «Innym» jest więc jednocześnie spotkaniem z samym sobą. Od «Innego», tak jak od tekstu, mogę uzyskać nowe rozumienie samego siebie, a zyskując nowe rozumienie samego siebie staję się tym samym otwartym na «Innych»" (Murzyn 1999, s. 25).

\section{Planowanie pracy szkoły}

Każdy dyrektor, planując pracę placówki edukacyjnej, musi być przekonany do:

$\rightarrow$ wizji szkoły - jaka ona ma być w dłuższej perspektywie czasowej,

$\rightarrow$ misji szkoły - kierunków przyszłych działań, których proces realizacji jest wiarygodny i odnosi się do rzeczywistości,

$\rightarrow$ celów szkoły - realizowania działań, nadania im jednolitego kierunku. Potrzebne jest to do planowania pracy w szkole, stanowi źródło motywacji dla pracowników i podstawę skutecznego mechanizmu oceny oraz kontroli.

Musi on również przygotować niezbędne dokumenty - plany:

$\rightarrow$ organizacyjne (plan nauczania, arkusz organizacji pracy szkoły, roczny plan pracy szkoły, plan nadzoru pedagogicznego i pracy zespołów),

$\rightarrow$ doskonalenia zawodowego,

$\rightarrow$ techniczne (zakup pomocy dydaktycznych, remontów itp.).

Dyrektor bierze pod uwagę to, że działania dydaktyczno-wychowawcze i zarządzanie szkołą muszą być zawsze przemyślane, zaplanowane i konsultowane z nauczycielami oraz z rodzicami. Areną do analizy potrzeb szkoły, rozwiązywania problemów, usprawniania kadry, wymiany doświadczeń będzie struktura zwana „doskonaleniem wewnątrzszkolnym". Czasem wymaga ona wsparcia środowiska lokalnego, a szczególnie rodziców, czyli najważniejszych osób decydujących o sposobie wychowania dzieci. Takie podejście pomoże w projektowaniu i przewidywaniu działań, przybliżając szkołę do życia. 
Przeprowadzając ewaluację swojej pracy, widzę, że dzięki dobremu planowaniu udało nam się stworzyć zespół, angażujący wszystkich pracowników szkoły: nie ma osoby niepotrzebnej, każdy ma swoje zadania w łańcuszku codziennych działań (Tarwacki 2011, s. 51). Planowanie pracy placówki musi odpowiadać potrzebom środowiska, w którym ona funkcjonuje. Dbając o wszystkie elementy układanki, jaką jest funkcjonowanie szkoły, a także szanując każdego uczestnika procesu edukacyjnego, można odnieść sukces. 


\title{
2.2. Finansowanie zadań oświatowych w edukacji włączającej
}

\author{
Liliana Zientecka
}

Realizacja idei edukacji włączającej wysokiej jakości wiąże się z odpowiednimi regulacjami w prawnymi i skutecznym modelem finansowania. Autorka analizuje obecne unormowania finansowe w polskim systemie oświaty, wskazując jednocześnie proponowane kierunki zmian, dzięki którym możliwe będzie skuteczniejsze wsparcie wszystkich uczniów, także tych ze specjalnymi potrzebami edukacyjnymi.

\section{Słowa kluczowe:}




\subsection{Hinancing of educational tasks in inclusive education}

Liliana Zientecka

Implementation of the idea of high-quality inclusive education requires implementation of corresponding regulations in the legal system and effective model of financing. The author analyses current financial regulations in Polish education system and indicates the proposed directions of changes, allowing to provide more effective support for all students, including those with special educational needs.

\section{Keywords:}




\section{Wstęp}

Realizacja wizji edukacji włączającej wysokiej jakości w polskim systemie oświaty powiedzie się, gdy jej główne założenia będą miały mocne oparcie w prawie oświatowym i modelu finansowania jego zadań. W ostatnich latach dynamicznie wzrasta liczba uczniów z niepełnosprawnościami w szkołach ogólnodostępnych. W roku szkolnym 2016/2017 ponad $60 \%$ z nich uczyło się w systemie edukacji włączającej', a w roku 2018/2019 wskaźnik ten wzrósł do $67 \%^{2}$. Dodatkowo, około $30 \%$ objętych jest pomocą psychologiczno-pedagogiczną i innymi formami wsparcia ${ }^{3}$. Takie dane pozwalają na stwierdzenie, że w wymiarze statystycznym edukacja włączająca jest w Polsce faktem. Ta sytuacja sprawia, że niezbędny jest przejrzysty system finansowania zadań oświatowych, który uwzględnia prymat szkół ogólnodostępnych w kształceniu uczniów ze specjalnymi potrzebami edukacyjnymi. $\mathrm{Na}$ tle diagnozy obowiązujących zasad podziału subwencji oświatowej widoczna jest pilna potrzeba wprowadzenia takich zmian, które zapewnią wszystkim uczniom - nie tylko tym, którzy zostali zakwalifikowani do kształcenia specjalnego - gwarancję odpowiedniego wsparcia. Środki finansowe przewidziane w odrębnych wagach na uczniów z niepełnosprawnością powinny być przyznawane bardziej celowo, a dyrektor szkoły, w największym stopniu odpowiadający za jakość kształcenia w systemie edukacji włączającej, powinien mieć pewien zakres swobody w ich wykorzystaniu. Zaprezentowane kierunki zmian finansowania zadań oświatowych w edukacji włączającej są wynikiem prac Zespołu do spraw opracowania modelu kształcenia uczniów ze specjalnymi potrzebami edukacyjnymi działającego przy Ministrze Edukacji Narodowej ${ }^{4}$, rekomendacji nr 6 Europejskiej Agencji

2 Dane z Departamentu Współpracy z Samorządem Terytorialnym Ministerstwa Edukacji Narodowej.

3 Uzasadnienie do projektu z dnia 5 listopada 2018 r. rozporządzenia Ministra Edukacji Narodowej w sprawie sposobu podziału części oświatowej subwencji ogólnej dla jednostek samorządu terytorialnego w roku 2019, bit.ly/2WI9ZpP [dostęp: 3.06.2019].

4 Zespół do spraw opracowania modelu kształcenia uczniów ze specjalnymi potrzebami edukacyjnymi, który został powołany przez Ministra Edukacji Narodowej Zarządzeniem nr 39 z dnia 13 października 2017 r. 
do spraw Specjalnych Potrzeb i Edukacji Włączającej ${ }^{5}$ oraz wielu lat polskich doświadczeń w zarządzaniu oświatą.

\section{Ogólne zasady finansowania zadań oświatowych}

Polski system oświaty funkcjonuje w warunkach decentralizacji administracji publicznej i zdecentralizowanego systemu przekazywania środków publicznych na zadania oświatowe. Fundamentalną zasadą podziału subwencji jest założenie, że „pieniądz idzie za uczniem”. Minister edukacji narodowej, korzystając z danych w Systemie Informacji Oświatowej (SIO) ${ }^{6}$ oraz algorytmu opisanego w rozporządzeniu, ustala jej wysokość na dany rok budżetowy, odrębnie dla każdej z 2807 jednostek samorządu terytorialnego. Istotnym instrumentem dystrybucji środków finansowych jest liczba i rodzaj wag, na podstawie których przekazywane są dodatkowe pieniądze, stanowiące zabezpieczenie finansowe realizacji ponadstandardowych zadań oświatowych. Wartość wag jest asymetrycznie zróżnicowana (od 0,012 do 10). W praktyce podstawowym elementem polityki państwa $\mathrm{w}$ finansowaniu zadań oświatowych jest regulacja wskaźników i wag, w tym tych przeznaczonych na uczniów objętych kształceniem specjalnym. Mocną stroną polskiego systemu jest płynność przekazywania środków do budżetów jednostek samorządu terytorialnego, a słabą - dość duża swoboda w ich dystrybucji do planów finansowych szkół, co oznacza, że pieniądze transferowane w subwencji na określone zadania oświatowe nie muszą być w całości przekazane do placówek, które je realizują. Ten problem w największym stopniu ujawnił się w przypadku uczniów objętych kształceniem specjalnym w systemie edukacji włączającej. Ministerstwo Edukacji Narodowej w ramach podziału subwencji oświatowej corocznie przeznacza stosunkowo duże środki na organizację kształcenia specjalnego. W 2019 r. na ten cel wyasygnowano $7,85 \mathrm{mld} z \nmid$, co stanowi $17,1 \%$ całej kwoty

6 Podstawą naliczenia subwencji oświatowej na dany rok budżetowy są dane z SıO (z dnia 30 września roku poprzedzającego rok budżetowy) obejmujące wszystkie publiczne i niepubliczne przedszkola, szkoły i placówki oświatowe, niezależnie od tego, kto jest ich organem prowadzącym. 
części oświatowej subwencji ogólnej . Raport Najwyższej Izby Kontroli dowodzi, że systematyczny wzrost nakładów na kształcenie specjalne nie idzie w parze z jakością działań na rzecz uczniów. W połowie skontrolowanych szkół i przedszkoli nie zapewniono właściwego wsparcia uczniom z niepełnosprawnościami, a pieniądze przekazane na ich kształcenie zostały wykorzystane na inne zadania oświatowe. Mimo że od 2015 r. wprowadzono wymóg, by jednostki samorządu terytorialnego (JST), a także szkoły i przedszkola planowały oraz ewidencjonowały wydatkowanie środków dodatkowo przekazanych na organizację kształcenia specjalnego w odrębnych, nowo utworzonych rozdziałach klasyfikacji budżetowej, to w 2016 r.:

$\rightarrow$ tylko 29\% JST zaplanowało i wykorzystało otrzymane środki,

$\rightarrow 32 \%$ JST zaplanowało, ale nie wykorzystało pieniędzy, które do nich trafiły,

$\rightarrow 39 \%$ JST nie zaplanowało i nie wykorzystało uzyskanych środków finansowych.

\section{Specjalne potrzeby edukacyjne uczniów - aspekt finansowy}

Specjalne potrzeby edukacyjne uczniów wymagają szczególnej organizacji form i metod pracy, co często wiąże się z koniecznością zatrudnienia specjalistów i ponoszenia dodatkowych kosztów. Obecny model podziału subwencji oświatowej zawiera dość stabilny system finansowania uczniów objętych kształceniem specjalnym, ale pokrycie kosztów specjalnych potrzeb edukacyjnych uczniów, którzy nie mają orzeczenia, nie jest uregulowane. W podziale subwencji na 2019 r. uwzględniono cztery wagi dla szkół, na podstawie których na ucznia objętego kształceniem specjalnym przekazywane są dodatkowe transfery finansowe ${ }^{9}$. Na takiego ucznia przekazywany jest zarówno transfer finansowy zgodnie ze standardem A (jak na każdego statystycznego ucznia), jak i dodatkowy, którego wysokość zależy od wartości wagi Narodowej. z niepełnosprawnościami w ogólnodostępnych szkołach i przedszkolach, s. 7, bit.ly/2WN99BG [dostęp: 3.06.2019]. 
przypisanej danemu rodzajowi niepełnosprawności, niedostosowania społecznego lub zagrożenia tym niedostosowaniem. Poniżej wykres pokazujący wartość wag, na podstawie których przekazywane są szkołom środki finansowe na organizowanie kształcenia specjalnego.

Wykres 1. Porównanie wartości transferów finansowych przekazywanych na uczniów objętych odpowiednio kształceniem specjalnym lub zajęciami rewalidacyjno-wychowawczymi w stosunku do wartości standardu A przekazywanego na każdego statystycznego ucznia w 2019 r.

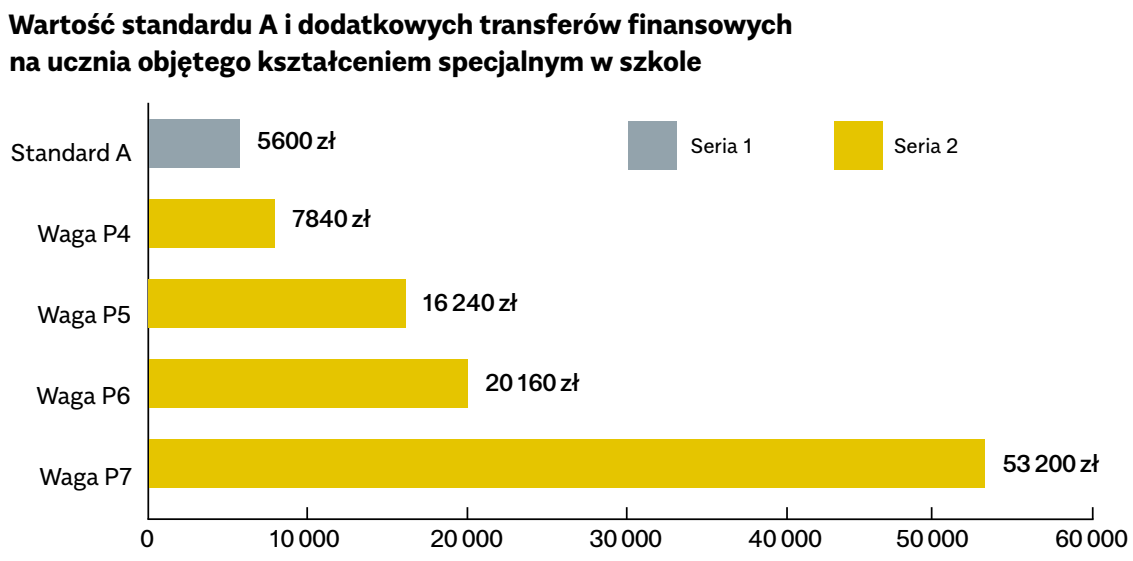

Waga P4 = 1,40 dla uczniów z niepełnosprawnością intelektualną w stopniu lekkim, niedostosowanych społecznie, zagrożonych niedostosowaniem społecznym, na podstawie orzeczeń o potrzebie kształcenia specjalnego.

Waga P5 = 2,90 dla uczniów niewidomych, słabowidzących, z niepełnosprawnością ruchową, w tym z afazją, na podstawie orzeczeń o potrzebie kształcenia specjalnego. Waga P6 = 3,60 dla uczniów niesłyszących, słabosłyszących, z niepełnosprawnością intelektualną w stopniu umiarkowanym lub znacznym, na podstawie orzeczeń o potrzebie kształcenia specjalnego.

Waga P7 = 9,50 dla dzieci i młodzieży z niepełnosprawnością intelektualną w stopniu głębokim, spełniających obowiązek szkolny lub obowiązek nauki przez udział w zajęciach rewalidacyjno-wychowawczych organizowanych w szkołach, ośrodkach i poradniach psychologiczno-pedagogicznych, dla uczniów z niepełnosprawnościami sprzężonymi oraz z autyzmem, w tym z zespołem Aspergera, na podstawie odpowiednio orzeczeń o potrzebie zajęć rewalidacyjno-wychowawczych lub orzeczeń o potrzebie kształcenia specjalnego. 
Jak widać, środki przewidziane na uczniów objętych kształceniem specjalnym są znaczne. Trudno jednak znaleźć merytoryczne uzasadnienie przekazywania na kształcenie specjalne ucznia niewidomego takiej samej kwoty jak na ucznia słabowidzącego (waga P5). Podobne wątpliwości budzi waga P6, na podstawie której duża kwota, konieczna do organizacji kształcenia ucznia niesłyszącego, uwzględnia także ucznia słabosłyszącego, którego edukacja nie generuje tak wysokich kosztów. Wykaz w wadze P7 (niepełnosprawność intelektualna w stopniu głębokim, umiarkowanym i znacznym, autyzm, w tym zespół Aspergera) skutkuje tym, że na kształcenie wysokofunkcjonującego ucznia z zespołem Aspergera przekazywane są takie same kwoty jak na kształcenie osoby z niepełnosprawnością intelektualną w stopniu głębokim. Ta daleko posunięta unifikacja finansowania osób objętych kształceniem specjalnym, dokonywana na podstawie przynależności do szeroko rozumianego rodzaju niepełnosprawności, generuje liczne nieprawidłowości w wykorzystaniu środków przekazywanych do organów prowadzących szkoły. Wcześniej przywołany raport Najwyższej Izby Kontroli ${ }^{10}$ pokazuje, jak w praktyce finansowane są szkoły realizujące kształcenie specjalne w systemie włączenia. „W większości skontrolowanych szkół i przedszkoli na przeszkodzie właściwej realizacji edukacji włączającej stanęły ograniczone zasoby finansowe i kadrowe. Jednakże aż $75 \%$ placówek nie wykorzystywało istniejących możliwości zapewnienia właściwego finansowania kształcenia specjalnego. W latach 2015-2016 nie wydatkowano w szkołach i przedszkolach przysługujących środków w ramach części oświatowej subwencji ogólnej".

Tę niekorzystną diagnozę funkcjonowania edukacji włączającej w obszarze finansowym dopełnia fakt, że obecny model podziału subwencji oświatowej nie przewiduje systemowego wsparcia uczniów, których potrzeby edukacyjne uwarunkowane są innymi przyczynami niż niepełnosprawność. Tymczasem w polskich szkołach ogólnodostępnych systematycznie wzrasta liczba uczniów potrzebujących wsparcia z powodu parcjalnych lub fragmentarycznych zaburzeń rozwojowych, zaniedbań środowiskowych, zagrożenia niedostosowaniem społecznym, odmienności kulturowej i językowej. Takie osoby powinny mieć możliwość skorzystania z pomocy psychologiczno-pedagogicznej, 
ale jej dostarczenie nie jest zadaniem dodatkowo subwencjonowanym, co sprawia, że trudno wyegzekwować skuteczne działania wspierające tych uczniów, zwłaszcza wtedy, gdy konieczne jest zaangażowanie specjalisty. Pierwsze próby uruchomienia ścieżki finansowania pomocy psychologiczno-pedagogicznej w szkołach pojawiły się w podziale subwencji oświatowej na 2019 r. w wagach P46 i P47. Informacje o powodach ich wprowadzenia można znaleźć w uzasadnieniu do projektu rozporządzenia w sprawie sposobu podziału części oświatowej subwencji ogólnej dla jednostek samorządu terytorialnego w roku 2019.

„Projekt przewiduje wprowadzenie dwóch wag na realizację działań z zakresu pomocy psychologiczno-pedagogicznej o wartości 0,025 dla szkół podstawowych i gimnazjum (waga P46) i o wartości 0,012 dla szkół ponadpodstawowych (waga P47). Waga obejmie uczniów z kategorii dzieci i młodzież (wszystkich, a nie tylko objętych pomocą) w szkołach ogólnodostępnych realizujących obowiązek szkolny lub nauki. Zróżnicowanie tych wag wynika z odsetka osób korzystających z pomocy psychologiczno-pedagogicznej w danym typie szkoły: w szkole podstawowej i gimnazjum średnio w kraju 35\% uczniów jest objętych pomocą psychologiczno-pedagogiczną, w szkołach ponadpodstawowych ok. 19\%"11.

\section{Proponowane kierunki zmian}

\section{w finansowaniu edukacji włączającej}

Zakładane cele edukacji włączającej powinny być osiągane w pierwszej kolejności przez systematyczne wzmacnianie potencjału szkół ogólnodostępnych, ponieważ te placówki muszą wziąć odpowiedzialność za zaspokajanie potrzeb swoich uczniów bez nadmiernego formalizowania udzielanej pomocy. Nowy model finansowania powinien uwzględniać potrzeby uczniów rozpoznane w szkole, a nie tylko te, które są skutkiem diagnozy przeprowadzonej w poradni psychologiczno-pedagogicznej i określone w orzeczeniu lub opinii. Szkoła powinna dysponować podstawowym zasobem specjalistów, którzy ukierunkują jej działania na profilaktykę problemów rozwojowych uczniów i wczesną interwencję. Opisane wcześniej wagi P46 i P47 na organizację pomocy psycholo- 
giczno-pedagogicznej są właściwym kierunkiem zmian i powinny być kontynuowane do czasu, gdy szkoły ogólnodostępne osiągną standardy zatrudnienia specjalistów w szkole włączającej ${ }^{12}$.

Głębokich modyfikacji wymaga także obecny model finansowania kształcenia specjalnego w systemie edukacji włączającej. Uczniowie zakwalifikowani do tej kategorii kształcenia wymagają wysokospecjalistycznego wsparcia nauczycieli, dostosowania przestrzeni szkolnej i stanowiska pracy, a niekiedy również ponadstandardowych warunków opieki medycznej i pomocy asystenta. Każda szkoła, w tym włączająca, powinna zapewnić im całościowe wsparcie, a system finasowania - znaleźć właściwą formułę przekazania środków na ten cel. Mając na uwadze krytyczne raporty dotyczące aktualnego modelu finansowania kształcenia specjalnego należy poszukiwać form bardziej celowej dystrybucji środków, odpowiadającej potrzebom danego ucznia, a nie szeroko rozumianej grupy osób z daną kategorią niepełnosprawności. To założenie skłania do poszukiwania drogi odejścia od finansowania rodzaju niepełnosprawności na rzecz finansowania potrzeb konkretnego ucznia. Ten tok myślenia jest spójny z kierunkiem zmian w orzecznictwie o stopniu niepełnosprawności przyjętym w resorcie rodziny, pracy i polityki społecznej oraz orzecznictwie w systemie oświaty bazującym na ocenie funkcjonowania ucznia. Kierunek ten wynika z dążenia do tzw. jednego orzeczenia, wydawanego przez interdyscyplinarny zespół ${ }^{13}$, który ocenia potrzeby wsparcia w różnych sferach funkcjonowania ucznia, w tym także niezbędne dostosowania w środowisku. W prezentowanej poniżej koncepcji zmian w finansowaniu edukacji włączającej nie jest ważny rodzaj niepełnosprawności, ale poziom funkcjonowania ucznia i odpowiadający mu poziom koniecznego wsparcia.

\section{Finansowe dźwignie edukacji włączającej}

W celu realizacji założeń edukacji włączającej wysokiej jakości warto w miejsce czterech wag przypisanych kształceniu specjalnemu w szkołach ogólnodostępnych rozważyć wprowadzenie trzech nowych indo spraw opracowania modelu kształcenia uczniów ze specjalnymi potrzebami edukacyjnymi. 
strumentów finansowych, które łącznie tworzą dwie dźwignie edukacji włączającej.

Pierwsza dźwignia edukacji włączającej to finansowe wsparcie szkół włączających, które gwarantuje im możliwość zatrudnienia specjalistów oraz zapewnienia uczniom różnych form wspomagania w procesie kształcenia, bez konieczności uzyskiwania przez nich opinii i orzeczenia. Potrzeby w obszarze wsparcia uczniów rozpoznawane są w ciągu całego roku szkolnego w toku bieżącej pracy. Zmieniające się w czasie wymagania uczniów powodują, że jego formy i zakres muszą być modyfikowane. Wymaga to zagwarantowania szkołom takiego zasobu organizacyjnego, który umożliwi im realizację wsparcia możliwie najszybciej po rozpoznaniu potrzeby, bez konieczności przechodzenia żmudnych procedur administracyjnych. Najprostszym rozwiązaniem służącym osiągnięciu takiego skutku prawnego w obowiązującym modelu podziału subwencji oświatowej jest dodatkowa waga (instrument finansowy $n r$ 1), odpowiednio wyszacowana dla typu szkoły i ustalonego dla niej standardu zatrudnienia specjalistów. Funkcjonujące od 2019 r. wagi P46 i P47 w podziale subwencji oświatowej są początkiem zmian w tym kierunku.

Druga dźwignia edukacji włączającej dotyczy uczniów o złożonych potrzebach rozwojowych i edukacyjnych, których zaspokojenie wymaga dodatkowych działań szkoły w dłuższym czasie lub przez cały okres kształcenia. W tej grupie znajdą się osoby z niepełnosprawnością, którą należy rozumieć szerzej ${ }^{14}$ niż określają to obecne przepisy prawa oświatowego ${ }^{15}$. Żeby osiągnąć zakładaną przejrzystość i celowość przekazywania środków, wsparcie finansowe ucznia mogłoby się składać z dwóch instrumentów finansowych:

1. dodatkowej wagi w podziale subwencji oświatowej (instrument finansowy nr 2), odpowiadającej poziomowi funkcjonowania ucznia, oszacowanej na podstawie liczby godzin koniecznego ze specjalnymi potrzebami edukacyjnymi przyjęto definicję niepełnosprawności ucznia zgodną z konwencją ONZ o prawach osób niepełnosprawnych, która jest szersza niż obecny katalog niepełnosprawności uprawniających do objęcia ucznia kształceniem specjalnym. 
wsparcia nauczyciela, udzielanego w formie zindywidualizowanej (choć niekoniecznie indywidualnej) pomocy nauczyciela przedmiotu lub terapeuty,

2. dotacji celowej dla szkoły (instrument finansowy nr 3 ) na sfinansowanie koniecznego dostosowania przestrzeni szkolnej, w tym stanowiska pracy umożliwiającego pełne uczestniczenie ucznia z niepełnosprawnością w zajęciach.

Uprawnienia do korzystania $\mathrm{z}$ instrumentu finansowego $\mathrm{nr} 2$ nie powinny zależeć od stwierdzenia niepełnosprawności ucznia, nie wszystkie bowiem poważne zakłócenia rozwoju wymagające wsparcia wynikają z niepełnosprawności. Kosztownego wspomagania edukacyjno-specjalistycznego (okresowo lub trwale) mogą wymagać uczniowie $z$ trudnościami $w$ funkcjonowaniu, uwarunkowanymi np. stanem zdrowia czy przebytą traumą. W nowym modelu finansowania edukacji włączającej nie jest ważne, czy zostanie stwierdzony określony rodzaj niepełnosprawności lub czy nastąpi rozpoznanie zaburzenia ${ }^{16}$, ale to, jaki jest poziom funkcjonowania ucznia i odpowiadający mu rodzaj oraz zakres koniecznego wsparcia. Takie podejście umożliwi ograniczenie barier w zakresie pełnego uczestnictwa uczniów w życiu społeczności szkolnej. Wydaje się, że trafnym wskaźnikiem w określeniu potrzeb wynikających z poziomu funkcjonowania ucznia byłaby liczba godzin pracy nauczyciela. Przyjmując takie rozwiązanie, wskaźnik ten byłby podstawą ich sfinansowania. Zakłada się, że pula godzinowa przypisana szkole $w$ tym trybie byłaby przez nią elastycznie rozdzielana, zgodnie z potrzebami ucznia i ustaleniami zespołu wielospecjalistycznego, określającego indywidualny plan edukacyjny i monitorującego jego realizację. Liczby poziomów funkcjonowania ucznia i odpowiadające im liczby godzin wsparcia nauczyciela powinny zostać ustalone $w$ toku działań pilotażowych realizowanych w szkołach i poradniach psychologiczno-pedagogicznych we współpracy z organami prowadzącymi szkoły. Podstawą przyznania dotacji byłyby określone bariery po stronie szkoły, utrudniające funkcjonowanie ucznia.

Zaproponowany kierunek zmian w modelu finansowania zadań oświatowych w edukacji włączającej jest zgodny z rekomendacją na podstawie wiedzy z zakresu psychologii klinicznej i pedagogiki specjalnej. 
nr 6 Europejskiej Agencji do spraw Specjalnych Potrzeb i Edukacji Włączającej ${ }^{17}$.

„W ramach polityki edukacyjnej należy opracować mechanizmy finansowania wspierające rozwój wczesnej interwencji i profilaktyki, zamiast polegać na strategiach i podejściach opartych na kompensowaniu trudności w szkołach ogólnodostępnych.

Oznacza to:

$\rightarrow$ wprowadzenie modelu finansowania zapewniającego wszystkim osobom uczącym się, które tego potrzebują, gwarancję wysokiej jakości wsparcia w procesie uczenia się. Model ten powinien zapewnić odejście od stosowania formalnych procedur identyfikacji potrzeb, gdzie głównym kryterium uzyskania dostępu do wsparcia jest «etykietowanie» uczniów. Nowe podejście powinno zagwarantować odpowiednie finansowanie i zasoby umożliwiające wspieranie wszystkich osób uczących się, aby usunąć bariery w uczeniu się i uczestnictwie;

$\rightarrow$ zapewnienie środków finansowych, które mogą być wykorzystywane w elastyczny sposób przez dyrektorów szkół do wdrażania strategii zapobiegających występowaniu problemów i umożliwiających nauczycielom natychmiastową interwencję po ich zidentyfikowaniu;

$\rightarrow$ określenie mechanizmów finansowania skierowanych do osób uczących się, które wymagają bardziej złożonego i długoterminowego wsparcia".

\section{Podsumowanie}

W sytuacji, gdy polski system oświaty przygotowuje się do upowszechnienia edukacji włączającej wysokiej jakości, poszukiwanie nowego modelu finansowania uczniów ze specjalnymi potrzebami edukacyjnymi wydaje się naturalnym obowiązkiem państwa. Zbyt długo tkwimy w rozwiązaniach, których podstawy były tworzone w latach 90 . XX w., gdy polski system oświaty był segregacyjny, a model finansowania uczniów z niepełnosprawnością polegał na ustaleniu wskaźnika dla szkół specjalnych, których zasób kadrowy składa się z samych specjalistów z zakresu danej niepełnosprawności. Dynamicznie rozwijające 
się szkoły i klasy integracyjne spowodowały, że do podziału subwencji oświatowej wprowadzono wagi na uczniów z niepełnosprawnością jako podstawę prawną przekazania środków finansowych na ich kształcenie w szkołach ogólnodostępnych w formie integracji lub włączenia. Dzisiaj te rozwiązania już nie wystarczają. Potrzebny jest system finansowania dostosowany do myślenia o szkole, która nie dzieli uczniów na "przeciętnych" i tych „ze specjalnymi potrzebami”, ale dąży do urzeczywistnienia modelu kształcenia odpowiadającego na potrzeby każdego ucznia. Instrumentem finansowym wspierającym upowszechnienie edukacji włączającej może być także przeznaczenie części środków zaplanowanych na doskonalenie zawodowe nauczycieli, o których mowa w art. 70a Karty Nauczyciela, na doszkalanie w zakresie kompetencji i kwalifikacji potrzebnych do pracy w zespołach klasowych o zróżnicowanych potrzebach edukacyjnych.

Mam nadzieję, że zaprezentowane kierunki zmian w finansowaniu zadań oświatowych staną się istotnym głosem w dyskusji nad poszukiwaniem rozwiązań, które upowszechnią w Polsce edukację włączającą wysokiej jakości. 



\subsection{Nauczyciel w edukacji włączającej}

Beata Jachimczak

Sukces edukacji włączającej wiąże się z odpowiednim przygotowaniem kadry pedagogicznej do nowych zadań i wyzwań, wynikających z realizacji tej idei. W niniejszym rozdziale zwrócono uwagę na konieczność wprowadzenia niezbędnych zmian w zakresie kształcenia przyszłych nauczycieli i doskonalenia zawodowego obecnie pracujących. Wskazano również specyficzne elementy pracy w grupie zróżnicowanej wraz z przykładami rozwiązań metodycznych przydatnych w projektowaniu procesu nauczania/uczenia się uczniów ze specjalnymi potrzebami. Całość rozważań zamyka krótka analiza systemów wsparcia realizowanych w ramach koncepcji edukacji włączającej w Anglii i w Polsce.

\section{_ Słowa kluczowe:




\subsection{Teacher in inclusive education}

Beata Jachimczak

The success of inclusive education is related to the preparation of teaching staff for new tasks and challenges, related to the this idea. Attention is drawn to the need for changes in the education of future teachers and in-service training. The author also points out to the specificity of working with a diverse group while outlining methodological solutions useful in designing the teaching-learning process for students with special needs. The considerations end with a brief analysis of support systems implemented in the concept of inclusive education in England and Poland. 


\section{Jakie wykształcenie - co powinno się zmienić?}

Edukacja włączająca to nowe doświadczenia, obowiązki, przed którymi stają zarówno doświadczeni nauczyciele, jak i nowicjusze. Jest to grupa zawodowa na co dzień poddawana surowej ocenie wewnętrznej i zewnętrznej, obarczona odpowiedzialnością za kształtowanie przyszłych pokoleń, za tworzenie warunków wzrastania młodego człowieka i rozwijania jego kompetencji w zakresie wiedzy, samoświadomości, samoregulacji i motywacji. Wraz z wprowadzeniem do szkół idei edukacji włączającej nauczyciele po raz kolejny zadają sobie pytania: „Jeśli my tego nie zrobimy, to kto?", "Jeśli nie teraz, to kiedy?". W kontekście polityki oświatowej otwierającej się na różnorodność w szkole ogólnodostępnej nie należy stawiać pytań o to, czy ma ona sens, ale należy szukać odpowiedzialnych i efektywnych rozwiązań przygotowujących całą społeczność szkolną (w tym nauczycieli) do nowej, „wieloróżnorodnej" grupy, z którą zetknie się w swojej pracy.

Realizacja idei edukacji włączającej wprowadza wiele zmian w rzeczywistości szkolnej. Co za tym idzie, również w kształceniu (przygotowaniu) przyszłych i obecnych kadr istotne jest wprowadzenie do programów studiów nauczycielskich i pedagogicznych (także podyplomowych kwalifikacyjnych i doskonalących) obligatoryjnych treści z zakresu edukacji włączającej.

Warto w tym miejscu przypomnieć, że współczesne rozumienie włączenia nie koncentruje się na żadnej szczególnej grupie uczniów, czyli nie ogranicza się do osób ze specjalnymi potrzebami edukacyjnymi czy z niepełnosprawnością. Niemniej jednak one również będą uczestniczyły w edukacji przedszkolnej czy szkolnej, określanej mianem włączającej.

Jednym z koniecznych zakresów kształcenia kierunkowego przyszłych nauczycieli musi być zatem obszar treści odnoszących się do funkcjonowania uczniów ze specjalnymi potrzebami edukacyjnymi, w tym z niepełnosprawnością - co oznacza poznanie ich charakterystyki i specyfiki rozwojowej, możliwości, ale także potrzeb oraz wynikającego z nich zakresu wsparcia dla uczniów.

Z raportu powstałego w ramach projektu "Kształcenie nauczycieli przygotowujące do edukacji włączającej (TE4I)", zrealizowanego przez Europejską Agencję Rozwoju Edukacji Uczniów ze Specjalnymi Potrzebami (obecnie Europejskiej Agencji do spraw Specjalnych Potrzeb i Edukacji Włączającej), wynika jasno, że kształcenie nauczycieli stano- 
wi kluczowy element systemu, przekładający się w dużym stopniu na funkcjonowanie oświaty jako takiej, a więc także inicjowanie zmian potrzebnych do szerszego wprowadzenia edukacji włączającej (European Agency for Development in Special Needs Education 2012, s. 7). Agencja za najważniejsze wartości w pracy nauczyciela "włączającego" związane z procesem nauczania/uczenia się uznała:

$\rightarrow$ docenianie różnorodności (różnice między uczniami uznaje się za zaletę i czynnik sprzyjający edukacji),

$\rightarrow$ wspieranie wszystkich uczniów (nauczyciele spodziewają się, że każdy z jego podopiecznych dokona znaczących postępów w nauce),

$\rightarrow$ nastawienie na współpracę (wszyscy nauczyciele uznają kluczową rolę pracy zespołowej i współdziałania),

$\rightarrow$ indywidualny rozwój zawodowy (nauczanie opiera się na uczeniu się, nauczyciele biorą na siebie odpowiedzialność za kształcenie się przez całe życie) (European Agency for Development in Special Needs Education 2012, s.13).

Powyższe zasady, które powinny towarzyszyć kształceniu przyszłych nauczycieli i być przez nich wdrażane w codziennej pracy dydaktycznej i w ramach samorozwoju, nadal zbyt często są pomijane - zarówno w teorii, jak i w praktyce szkolnej (w tym w szkolnictwie wyższym). Deklarowane uznanie prawa do edukacji każdego dziecka dość często nie znajduje odzwierciedlenia w zachowaniu pedagogów, a także w organizacji pracy placówki, która wbrew oczekiwaniom społecznym nie wyraża gotowości do bycia „szkołą dla każdego" i nie spełnia jej warunków. Badania naukowe (np. Chrzanowska 2018; Gajdzica 2011; Szumski 2010), jak również analiza praktyki szkolnej ${ }^{1}$, pokazują wiele nieprawidłowości w funkcjonowaniu placówek oświatowych, w tym przede wszystkim: brak współodpowiedzialności, kooperacji i - co za tym idzie - brak efektywnych rozwiązań dotyczących radzenia sobie $w$ grupach i klasach zróżnicowanych ze względu na możliwości i ograniczenia edukacyjne uczniów. Najbardziej niepokojące z punktu widzenia omawianych zagaddyrektorem wydziału edukacji dużego miasta, obecnie zaś - pełnomocnikiem prezydenta miasta ds. programów i projektów edukacyjnych (w tym ukierunkowanych na pracę z uczniem ze specjalnymi potrzebami edukacyjnymi). 
nień wydaje się niedostrzeganie problemów indywidualizacji pracy oraz pojawienie się potencjalnych problemów interakcyjnych w grupie wraz z dołączeniem do niej ucznia o odmiennych potrzebach i możliwościach psychospołecznych. Część nauczycieli w takiej sytuacji koncentruje się wyłącznie na osiąganiu wspólnych (ujednoliconych) celów dydaktycznych i odrzuca lub odsuwa na plan dalszy zobowiązanie do prowadzenia diagnozy funkcjonalnej i podejmowania działań profilaktycznych oraz terapeutycznych wobec dziecka, a nawet całej grupy.

Znaczenie ma zatem uwzględnienie w programach studiów (różnego typu) przygotowujących nauczycieli do nowych realiów edukacji włączającej treści dotyczących jej założeń teoretycznych oraz metodyki pracy z grupami zróżnicowanymi.

Ważne jest, po pierwsze, by myśląc o specjalnych potrzebach edukacyjnych, koncentrować się na wszelkich możliwych wariantach funkcjonowania ucznia, wynikających ze specyfiki jego rozwoju (związanych np. z niepełnosprawnością lub wybitnymi zdolnościami), z sytuacji życiowej dziecka i jego rodziny (np. niewydolności wychowawczej rodziny, zaniedbań rozwojowych, ale również problematyki migracji w szerokim znaczeniu - w odniesieniu do dzieci cudzoziemskich, polskich powracających z zagranicy i takich, których rodzice przebywają poza krajem).

Drugim dużym blokiem treści niezbędnych w kształceniu przyszłych pedagogów jest problematyka projektowania uniwersalnego, racjonalnych dostosowań, pracy z grupą zróżnicowaną. Idea edukacji włączającej zakłada, że istotne są potrzeby każdego ucznia, a efektem prawidłowo realizowanego procesu kształcenia ma być jego rozwój na miarę maksymalnych możliwości w każdym obszarze funkcjonowania (poznawczym, społecznym, emocjonalnym, fizycznym), osiągany dzięki stworzeniu mu najlepszych ku temu warunków.

Trzeci istotny obszar treści odnosi się do kompetencji diagnostycznych związanych z modelem biopsychospołecznego rozwoju człowieka. Jednym z kluczowych zakresów działalności nauczyciela będzie w warunkach edukacji włączającej diagnozowanie (bieżące) potrzeb ucznia, umożliwiające planowanie działań dydaktyczno-wychowawczych, projektowanie wsparcia, dostosowywanie do jego potrzeb otoczenia, treści, metod, form, środków dydaktycznych, kryteriów oceniania i organizacji pracy.

W ramach kierunków nauczycielskich, czyli w odniesieniu do nauczycieli: 
$\rightarrow$ wczesnej edukacji (przedszkola i etap wczesnoszkolny),

$\rightarrow$ przedmiotowych pracujących w klasach IV-VIII szkoły podstawowej,

$\rightarrow$ przedmiotowych w szkołach ponadpodstawowych,

wszystkie te treści powinny być uwzględnione w koniecznym wymiarze: modułów (przedmiotów) kształcenia i godzin zajęć, zapewniając im w ten sposób podstawową wiedzę i konieczne umiejętności.

Istotne jest, by kształcenie we wskazanych obszarach realizowane było przez odpowiednio przygotowanych - z uwzględnieniem kwalifikacji formalnych i (lub) dorobku naukowego - nauczycieli akademickich. Na przykład treści z zakresu pedagogiki specjalnej czy specjalnych potrzeb edukacyjnych powinny być realizowane przez wykładowców związanych z tą dziedziną i posiadających dorobek naukowy w tym zakresie.

Przewidywać można, że z uwagi na zróżnicowane i coraz bardziej różnorodne potrzeby oraz możliwości uczniów (w tym związane ze zmianami cywilizacyjnymi), w każdym przedszkolu i w każdej szkole potrzebna będzie grupa wysokiej klasy specjalistów zorientowanych na wspieranie edukacji włączającej (nauczycieli, rodziców) oraz nauczycieli specjalizujących się w pracy z homogenicznymi grupami uczniów (np. z niepełnosprawnością wzroku, słuchu czy intelektualną). Dlatego konieczne wydaje się przeprojektowanie kształcenia nauczycieli - pedagogów specjalnych.

Dobrym rozwiązaniem byłoby założenie, że każdy przyszły nauczyciel, absolwent kierunku pedagogika specjalna, powinien posiadać kwalifikacje w zakresie:

1. Edukacji włączającej, uzyskane w trakcie studiów przez realizację obligatoryjnego modułu kształcenia w wymiarze nie mniejszym niż 500 godzin, włączając $w$ to praktykę pedagogiczną w wymiarze minimum 120 godzin. Zdobyte umiejętności i wiedza powinny obejmować takie zagadnienia, jak:

$\rightarrow$ współpraca z nauczycielami i specjalistami w tworzeniu programów wsparcia, ich monitorowania, ewaluacji i modyfikacji, doradztwo dla rodziców w zakresie realizacji zadań edukacyjnych;

$\rightarrow$ wspomaganie rodziców $\mathrm{w}$ aktywnym uczestnictwie w procesie kształcenia ich dzieci, w utrzymywaniu kontaktu z przedszkolem i szkołą, wymianie doświadczeń w celu zaplanowania i realizacji edukacji najwyższej jakości, włącznie z wyborem optymalnej ścieżki kształcenia; 
$\rightarrow$ wspieranie rodziców $\mathrm{i}$ ich dziecka w okresach przejścia między etapami kształcenia, typami placówek;

$\rightarrow$ diagnozowanie potrzeb i możliwości dziecka;

$\rightarrow$ współorganizowanie kształcenia dla uczniów ze specjalnymi potrzebami edukacyjnymi;

$\rightarrow$ realizacja zajęć specjalistycznych wpływających na rozwój i edukację ucznia, szczególnie w zakresie rehabilitacji edukacyjnej;

$\rightarrow$ doradztwo w zakresie pracy w grupie zróżnicowanej;

$\rightarrow$ dobór metod, form kształcenia, środków dydaktycznych itp.;

$\rightarrow$ wspieranie nauczycieli, wychowawców i innych specjalistów oraz rodziców w rozpoznawaniu indywidualnych potrzeb rozwojowych i edukacyjnych uczniów, ich możliwości psychofizycznych, predyspozycji, zainteresowań oraz uzdolnień, przyczyn niepowodzeń szkolnych, trudności w funkcjonowaniu, w tym barier i ograniczeń związanych z uczestnictwem w życiu społecznym;

$\rightarrow$ projektowanie uniwersalne i wprowadzanie racjonalnych dostosowań oraz modyfikacji uwzględniających potrzeby uczniów;

$\rightarrow$ planowanie i realizacja skutecznych strategii ukierunkowanych na tworzenie warunków rozwijania potencjału każdego ucznia i jego społecznego włączania.

2. Wybranej specjalności związanej z homogeniczną subdyscypliną pedagogiki specjalnej (dotyczącą np. osób z niepełnosprawnością wzroku, słuchu, intelektualną), która da absolwentom pogłębione kompetencje, przydatne $w$ pracy z podopiecznymi z danym rodzajem niepełnosprawności w różnych obszarach i fazach ich życia, od wczesnego dzieciństwa po dorosłość.

W celu podniesienia jakości kształcenia przyszłych nauczycieli (na poziomie edukacji przedszkolnej i wczesnoszkolnej oraz pedagogów specjalnych) od roku szkolnego 2019/2020 przewiduje się wprowadzenie zmiany, zgodnie z którą odbywać się ono będzie w ramach jednolitych studiów pięcioletnich. Nauczyciele przedmiotowi nadal będą zdobywali wiedzę na studiach dwustopniowych: trzyletnich licencjackich i dwuletnich magisterskich uzupełniających.

Problem kształcenia nauczycieli przedmiotów klas IV-VIII i pedagogów ze szkół ponadpodstawowych wydaje się istotny, jeśli przyjmujemy, że edukacja włączająca ma się koncentrować na dostosowaniu wymagań, warunków i organizacji nauki do potrzeb ucznia 
z punktu widzenia jego całożyciowej edukacji, w tym kształcenia zawodowego, wejścia i uczestnictwa w rynku pracy. To z nauczycielami na tym poziomie uczniowie realizują najdłuższy etap procesu kształcenia (trwający łącznie 8-10 lat) i to właśnie ta kadra powinna zostać doskonale przygotowana do wypełniania swoich obowiązków. Obecnie problematyka pracy w grupie zróżnicowanej na studiach nauczycielskich realizowanych poza kierunkami pedagogicznymi jest właściwie nieobecna. Często nie ma tam nawet pojedynczych modułów (przedmiotów kształcenia) w minimalnym wymiarze godzinowym z zakresu pracy z uczniem ze specjalnymi potrzebami edukacyjnymi. Przyszli nauczyciele historii, matematyki czy chemii w Polsce nie kończą zazwyczaj nawet podstawowego kursu z zakresu pedagogiki specjalnej. Trudno sobie wyobrazić, że będą oni skutecznie współpracować z uczniami ze specjalnymi potrzebami edukacyjnymi - wspierać ich, dostosowywać wymagania edukacyjne (program, treści), warunki nauki czy warunki organizacyjne do ich potrzeb i możliwości (Jachimczak 2018).

Z doświadczeń pracy Zespołu do spraw wypracowania wzorców projakościowych na kierunkach pedagogicznych i niepedagogicznych z prowadzoną specjalnością nauczycielską przy Polskiej Komisji Akredytacyjnej (PKA) ${ }^{2}$ wynika, że prawdopodobnie trudno będzie w wymiarze godzinowym w obecnych programach kształcenia zmieścić dodatkowe treści związane z problematyką edukacji włączającej.

Optymizmem nie napawają również projekty modyfikacji standardów kształcenia nauczycieli przedmiotów ${ }^{3}$, które mają pojawić się jeszcze w 2019 r. Eksperci zajmujący się problematyką edukacji włączającej apelowali o zmiany w tym zakresie. Wskazywali, że jeśli ma być w Polsce realizowana idea "szkoły dla wszystkich”, to nauczyciele muszą mieć przynajmniej podstawowe kompetencje w tym zakresie, wystarczające do tego, by zrozumieć i rozpoznać specyfikę funkcjonowania uczniów w grupie zróżnicowanej i rozpocząć pracę zindywidualizowaną. Przygotowanie w zakresie specjalnych potrzeb edukacyjnych na poziomie studiów powinno też wzmóc potrzebę i gotowość nauczycieli do dalszego

3 Projekt był prezentowany podczas Forum Jakości 2017 „O nową jakość kształcenia nauczycieli”, 16-17 listopada 2017 r. w Krakowie. Przebieg prac w ramach projektu Ministerstwa Nauki i Szkolnictwa Wyższego „Opracowanie modelowych programów kształcenia nauczycieli” zreferowali prof. dr hab. Bożena Muchacka (PKA, UP), dr Jerzy Lackowski (UJ) oraz dr Stanisław Kowal (UP). 
samodoskonalenia zawodowego (np. w ramach studiów podyplomowych kwalifikacyjnych, kursów lub szkoleń doskonalących). Analiza projektów przyszłych standardów kształcenia nauczycieli wskazuje jednak, że zabrakło w nich jednoznacznego odniesienia do treści związanych ze zmianami w zakresie współpracy z uczniami ze specjalnymi potrzebami edukacyjnymi. Jest to zjawisko niepokojące z punktu widzenia zarówno obecnych kadr, jak i osób, które będą zajmowały się kolejnymi rocznikami dzieci. Uczucie niepewności wielu pracujących nauczycieli, ale i dyrektorów placówek edukacyjnych, względem edukacji włączającej jest - do pewnego stopnia - konsekwencją poczucia niekompetencji (Bartnikowska, Wójcik 2004; Gajdzica 2001; Westwood 2013), wynikającego z coraz powszechniejszego pojawiania się w szkołach ogólnodostępnych uczniów (różniących się od siebie), którzy wcześniej realizowali obowiązek kształcenia w edukacji specjalnej. W związku z tym bardzo ważnym elementem szkoły włączającej byliby nauczyciele przygotowani do pracy w niej już w toku swojego podstawowego kształcenia w trakcie studiów. Aby jednak tak mogło się stać, potrzebne jest zaangażowanie osób kreujących politykę kształcenia nauczycieli w Polsce oraz kadr akademickich na kierunkach niepedagogicznych.

Zanim nowi absolwenci zreformowanego kształcenia znajdą zatrudnienie w placówkach oświatowych (czyli najwcześniej za pięć lat), skutecznym rozwiązaniem może być współodpowiedzialne planowanie ścieżek rozwoju osobistego poszczególnych pedagogów i nauczycieli pracujących w przedszkolach oraz szkołach w taki sposób, aby mogli oni stanowić interdyscyplinarny zespół mogący wspierać się wzajemnie w rozwiązywaniu problemów pojawiających się w związku z nową rzeczywistością edukacyjną.

Istotne zatem jest podkreślenie konieczności doskonalenia zawodowego pracujących nauczycieli i zdobywania przez nich kompetencji w zakresie edukacji włączającej. Oprócz wspomnianych zmian w kształceniu akademickim pojawiły się również propozycje wydłużenia czasu studiów podyplomowych (i innego rodzaju, nadających kwalifikacje w zakresie edukacji włączającej) do wymiaru godzinowego nie mniejszego niż proponowany w ramach studiów wyższych (przynajmniej 500 godzin), co umożliwia ich realizację w trakcie czterech semestrów. Ponadto wydaje się, że logicznym rozwiązaniem jest otoczenie tych studiów opieką merytoryczną uczelni z uprawnieniami do realizacji kształcenia na kierunku pedagogika specjalna. W ten sposób jest szan- 
sa na wprowadzenie do praktyki specjalistów posiadających wysokie kwalifikacje i kompetencje, zgodne ze współczesnym podejściem do edukacji włączającej, mogących realnie wspierać jej wdrażanie.

\section{Jak pracować z grupą zróżnicowaną}

- wyzwanie edukacji włączającej

Analizując publikacje metodyczne dotyczące pracy w grupie zróżnicowanej, można zauważyć, że najczęściej odnoszą się one do wieku dzieci. Zdecydowanie rzadziej nauczyciele dzielą się swoimi doświadczeniami z pracy z zespołami, w których oprócz uczniów „środka" ${ }^{4}$ najdują się ich rówieśnicy ze specjalnymi potrzebami edukacyjnymi, wynikającymi z:

$\rightarrow$ niepełnosprawności,

$\rightarrow$ niedostosowania społecznego i zagrożenia nim,

$\rightarrow$ zaburzeń zachowania lub emocji,

$\rightarrow$ specyficznych trudności w uczeniu się,

$\rightarrow$ deficytów kompetencji i zaburzeń sprawności językowej,

$\rightarrow$ choroby przewlekłej,

$\rightarrow$ sytuacji kryzysowych lub traumatycznych,

$\rightarrow$ niepowodzeń edukacyjnych,

$\rightarrow$ zaniedbań środowiskowych związanych z sytuacją bytową ucznia i jego rodziny,

$\rightarrow$ trudności adaptacyjnych związanych z różnicami kulturowymi lub ze zmianą środowiska edukacyjnego.

W grupie tej znajdują się również uczniowie zdolni. Analiza danych zawartych w literaturze (por. Chrzanowska 2015) wskazuje nawet 20-proc. udział w oddziałach uczniów z szeroko rozumianymi trudnościami w uczeniu się i funkcjonowaniu szkolnym. Właśnie ta różnorodność, wynikająca z możliwości i ograniczeń rozwojowych (w tym związanych z niepełnosprawnością), z potrzeb oraz oczekiwań indywidualnych i społecznych, stawia kadrę pedagogiczną szkół włączających przed nowymi wyzwaniami.

Uznanie przez nauczycieli założeń edukacji włączającej zazwyczaj skłania ich do postawienia pytań: „Jaka ma być szkoła otwarta na każde- 
go ucznia?", „Jak organizować proces nauczania/uczenia się w klasie?", "Czy koncentrować się na większości uczniów pracujących w podobnym tempie i na zbliżonym lub takim samym materiale treściowym?", "Czy skupiać się na uczniach wymagających wsparcia indywidualnego?". Często pojawiającym się pytaniem jest również to dotyczące zadań stawianych szkole: „Czy jej rolą ma być kształcenie i wychowanie czy oddziaływanie terapeutyczne?". Z formalnoprawnego punktu widzenia ostatnia kwestia wydaje się nieuzasadniona w związku z tym, że każda szkoła i każde przedszkole realizuje zadania wynikające z ustawy Prawo oświatowe, do których należą m.in.:

$\rightarrow$ wychowanie, rozumiane jako wspieranie dziecka w rozwoju ku pełnej dojrzałości w sferze fizycznej, emocjonalnej, intelektualnej, duchowej i społecznej, wzmacniane i uzupełniane przez działania z zakresu profilaktyki problemów dzieci i młodzieży;

$\rightarrow$ dostosowanie treści, metod i organizacji nauczania do możliwości psychofizycznych uczniów, a także umożliwienie korzystania z pomocy psychologiczno-pedagogicznej i specjalnych form pracy dydaktycznej;

$\rightarrow$ realizacja programów nauczania, które zawierają podstawę kształcenia ogólnego dla przedmiotów objętych ramowym planem nauczania;

$\rightarrow$ możliwość pobierania nauki we wszystkich typach szkół przez dzieci i młodzież z niepełnosprawnościami, osoby niedostosowane społecznie i zagrożone niedostosowaniem, zgodnie $z$ indywidualnymi potrzebami rozwojowymi i edukacyjnymi oraz predyspozycjami;

$\rightarrow$ opieka nad uczniami niepełnosprawnymi przez umożliwianie realizowania zindywidualizowanych procesów kształcenia, form i programów nauczania oraz zajęć rewalidacyjnych;

$\rightarrow$ opieka nad uczniami szczególnie uzdolnionymi przez umożliwianie prowadzenia indywidualnych programów nauczania oraz ukończenia szkoły każdego typu w skróconym czasie;

$\rightarrow$ kształtowanie u uczniów postaw prospołecznych, w tym poprzez możliwość udziału w działaniach z zakresu wolontariatu, sprzyjających aktywnemu uczestnictwu uczniów w życiu społecznym.

W związku z tym każda szkoła zobowiązana jest również do prowadzenia działań diagnostycznych ukierunkowanych na poznanie zróżni- 
cowania struktury własnej społeczności oraz do podejmowania działań profilaktycznych i wychowawczych wobec wszystkich uczestników procesu kształcenia, a więc: uczniów, nauczycieli oraz rodziców. Należy w tym miejscu podkreślić konieczność budowania rozwiązań systemowych ukierunkowanych na edukację włączającą, obejmujących całą placówkę, ponieważ tylko spójne, czytelne i realne projekty funkcjonujące w całej szkole będą mogły przynieść satysfakcjonujące efekty, czyli zaspokojenie potrzeb i oczekiwań poszczególnych jednostek.

Anna Brzezińska (2002) podkreśla, że sukcesy szkolne każdego ucznia zależą od jego aktywności, a także od dorosłych, tworzących mu warunki uczenia się. Inaczej mówiąc, są one wynikiem procesu wielorakiej interakcji (współgry) właściwości dziecka i właściwości placówki. Z jednej strony szkoła otwarta i gotowa na poszukiwanie pól do tej współgry poszczególnych uczestników procesów dydaktycznych i wychowawczych tworzy warunki edukacyjne, w których każdy uczeń, niezależnie od swoich indywidualnych potrzeb, może efektywnie i całkowicie spełniać się w wielu rolach. $Z$ drugiej - szkoła "zamknięta" na różnorodność może powodować pojawienie się sytuacji trudnych w kontekście prawidłowego funkcjonowania pojedynczych uczniów w zespole, a także całej grupy. Do najczęstszych "grzechów" popełnianych w placówkach oświatowych, a związanych z efektywnością edukacji włączającej, zaliczyć można: brak podmiotowego, zindywidualizowanego podejścia do ucznia, nadmierne skupienie się na działaniach dydaktycznych w związku z potrzebą zaspokojenia oczekiwań "rankingowych", zaniedbanie procesu wychowawczego, niedostateczną dbałość o relacje interpersonalne w placówce (grupie), brak uznania dla zróżnicowanych wartości, potrzeb i możliwości uczniów.

Ważne zatem jest poszukiwanie przez szkoły sposobów radzenia sobie w nowej, "włączającej” rzeczywistości edukacyjnej. Zbyszko Melosik (2007, s. 173-174) już ponad dziesięć lat temu wskazywał reakcje placówek edukacyjnych ukierunkowane na działanie w grupach zróżnicowanych. Jego analizy odnosiły się przede wszystkim do odmienności kulturowych, ale ich uniwersalizm pozwala na zastosowanie ich również w projektowanej „szkole dla każdego". Za skuteczne działania na rzecz włączania uczniów zagrożonych marginalizacją, a może nawet wykluczeniem, uznać można (wzorując się na propozycjach Melosika) m.in:

$\rightarrow$ wzbogacanie programu szkoły o informacje dotyczące grup mniejszościowych, defaworyzowanych, zagrożonych; 
$\rightarrow$ położenie nacisku na dostarczanie uczniom „doświadczeń społecznych", których, w opinii pedagogów, im brakuje;

$\rightarrow$ budowanie relacji, której punktem wyjścia jest uznanie indywidualnych potrzeb każdego członka wspólnoty edukacyjnej;

$\rightarrow$ eliminację zachowań dyskryminacyjnych ze środowiska szkoły (ze szczególnym nastawieniem na program i postawy nauczycieli);

$\rightarrow$ działania oparte na pojmowaniu mniejszości jako czegoś „innego", a nie "gorszego" i akcentowanie tego przez wprowadzanie treści dotyczących SPE do programu, ponadto akceptowanie stylów uczenia się pojedynczych osób lub grup mniejszościowych.

Wymienione rozwiązania dotyczą trudnych problemów pojawiających się w pracy w grupie heterogenicznej. Współczesne tendencje oświatowe zmierzają w kierunku łączenia różnych podmiotów we wspólnym nurcie kształcenia, uwzględniając zarówno grupy uczniów z niepełnosprawnością, jak i osoby odmienne kulturowo, zaniedbane społecznie, uzdolnione i wiele innych. W związku z tym coraz częściej nauczyciel będzie pracował ze zróżnicowanym zespołem klasowym, w którym pojawiać się będą obok siebie przedstawiciele wszystkich wcześniej wymienianych kręgów postrzeganych jako „odmienne” od większości rówieśników.

Iwona Chrzanowska (2018, s. 31) do najważniejszych kompetencji nauczyciela w pracy z grupą zróżnicowaną zalicza umiejętności:

$\rightarrow$ poznania uczniów, ich sposobów funkcjonowania w klasie, odgrywania ról, relacji w klasie, w grupie rówieśniczej;

$\rightarrow$ poznania sytuacji środowiskowej uczniów, problemów ich rodzin, aktywnego poszukiwania form wsparcia rodziny ucznia i udzielania wsparcia;

$\rightarrow$ poznania strategii uczenia się i stylów nauczania w celu ich doboru do zróżnicowanych potrzeb uczniów;

$\rightarrow$ projektowania przestrzeni klasy szkolnej, wykorzystania odpowiednich środków i pomocy dydaktycznych, podręczników, specjalistycznych narzędzi umożliwiających realizację treści kształcenia, ich adaptacji i doboru do zróżnicowanych potrzeb uczniów;

$\rightarrow$ wdrażania procesu motywowania podopiecznych do nauki i kształtowania pozytywnego stosunku do uczenia się;

$\rightarrow$ wykorzystania konwencjonalnych i niekonwencjonalnych metod nauczania oraz ich adaptacji do potrzeb uczniów; 
$\rightarrow$ stosowania szerokiego wachlarza organizacyjnych form kształcenia, w tym niekonwencjonalnych, bazujących na wzajemnym edukowaniu się uczniów i współpracy między nimi;

$\rightarrow$ dostosowania programów nauczania, treści kształcenia do potrzeb i możliwości uczniów;

$\rightarrow$ oceniania zróżnicowanych możliwości uczniów, zachowania motywującej funkcji ocen, budowania adekwatnej, ale również pozytywnej samooceny uczniów;

$\rightarrow$ współpracy z nauczycielami, specjalistami, rodzicami, osobami zarządzającymi oświatą i nadzorem pedagogicznym;

$\rightarrow$ opracowywania programów wychowawczych skoncentrowanych na potrzebach ucznia, klasy, społeczności szkolnej, a także ich koordynowania, monitorowania, ewaluacji i modyfikacji.

Praca w grupie zróżnicowanej, jak zostało wskazane, wymaga uznania przez nauczycieli prawa każdego dziecka do edukacji wśród rówieśników, w placówce, którą wybrali dla niego rodzice. Uznanie oznacza przyjęcie odpowiedzialności przez dorosłych za działania w czterech ważnych obszarach pracy pedagogicznej, dzięki którym można pomóc uczniowi budować prawidłowe relacje z samym sobą i z innymi. Należą do nich:

$\rightarrow$ poznanie: obserwacja dziecka na lekcji i poza nią, ocena wyników w nauce uwzględniająca punkt wyjściowy ucznia (wewnętrzna), nawiązanie kontaktu z rodzicami, pogłębiona analiza dokumentacji dotyczącej zdrowia dziecka, budowanie porozumienia z innymi nauczycielami na rzecz tworzenia środowiska wspierającego funkcjonowanie szkolne ucznia;

$\rightarrow$ zaakceptowanie: przyzwolenie na zachowania, które wynikają z zaburzeń rozwojowych i mogą być akceptowane przez innych, wprowadzenie zmiany w pracy z uczniem ze specjalnymi potrzebami edukacyjnymi, zamiast podważania wartości, postaw, norm;

$\rightarrow$ pozyskanie: budowanie autorytetu przez zainteresowanie się uczniem, koncentrowanie się na pozytywnych cechach, zachowaniach, umiejętnościach, dostarczanie wzmocnień pozytywnych w zakresie indywidualnym i grupowym;

$\rightarrow$ zmienianie: wspieranie naturalnej aktywności (każde dziecko ma swoją mocną stronę - punkt archimedesowy - sport, uzdolnienia artystyczne, poczucie humoru, zdolności organizacyjne itp.), unikanie kontroli i egzekwowania - stopniowe wycofywanie 
się z działań kontrolnych, współpartnerstwo - współodpowiedzialność (nauczyciel jako konsultant i doradca, demokratyczne ustalanie celów, zadań do wykonania, wskazywania konsekwencji podejmowanych decyzji), kontrakty indywidualne i grupowe (Chrzanowska, Jachimczak 2015, s. 189).

\section{Poznanie}

Poznanie dziecka, zrozumienie uwarunkowań jego funkcjonowania w wymiarze indywidualnym i w sytuacji społecznej (klasie szkolnej) to najważniejsze elementy budowania środowiska wspierającego jego rozwój. Uczniom ze specjalnymi potrzebami często będą towarzyszyć problemy w adaptacji do wymagań stawianych przez nauczycieli w obszarze zarówno wiedzy, jak i umiejętności szkolnych oraz społecznych. Ponieważ zmiana ucznia (jego rozwój, samozrozumienie i samokontrola) na tym etapie procesu edukacyjnego dopiero się rozpoczyna, konieczna wydaje się modyfikacja postaw nauczyciela. Jego gotowość do poszukiwania rozwiązań wspomagających funkcjonowanie dziecka od pierwszych dni jego pobytu w placówce może być gwarantem sukcesu szkolnego. Do najważniejszych zadań w tym obszarze należy rozpoznanie możliwości i ograniczeń ucznia oraz stworzenie planu pracy, którego celem będzie opis interwencji i tworzenia warunków niezbędnych do jego rozwoju (ze szczególnym zaznaczeniem obszaru społecznego).

Poznanie powinno być ukierunkowane również na pracę z każdym dzieckiem, nad tym, żeby samo siebie zrozumiało, poznało własne możliwości i ograniczenia. Ważnym elementem tego procesu jest także otwarty, autentyczny dialog z całym zespołem klasowym na temat różnorodności oraz związanych z nią zagrożeń oraz szans współdziałania i brania współodpowiedzialności. Żeby dialog wspierający (a nie zmierzający do poszukiwania winnego niepowodzeń, sytuacji trudnych) mógł zaistnieć, konieczne jest wewnętrzne przekonanie nauczyciela o pozytywnej sile różnorodności jako kapitału społecznego.

\section{Zaakceptowanie}

Kiedy poznamy i zrozumiemy indywidualne różnice w funkcjonowaniu uczniów, kolejnym zadaniem będzie odpowiedzialne i refleksyjne tworzenie przestrzeni edukacyjnej, która stanie się, jak twierdzi Dorota Podgórska-Jachnik (2007), miejscem dla inności, która może być czynnikiem wzbogacającym. W tej przestrzeni „inność” nie będzie identy- 


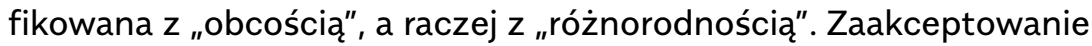
edukacji włączającej będzie podstawą zapewniania wszystkim uczniom równego dostępu do materialnych i osobowych zasobów szkoły, by na bazie równouprawnienia rozwinąć szczególne, wielorakie możliwości uczenia się i życia. Punktem wyjścia na drodze do osiągnięcia tego celu wcale nie jest inny człowiek, tylko sam nauczyciel lub uczeń: odniesienie do własnego poczucia godności, rozpoznanie własnych uczuć i emocji, łącznie z zaakceptowaniem wewnątrzpsychicznej heterogeniczności. To właśnie na bazie wewnętrznej godności i znajomości siebie tworzy się warunki bezpiecznego spotkania, poznania oraz uznania innych.

Do zadań realizowanych w klasie w celu budowania akceptacji siebie i innych może się przysłużyć:

$\rightarrow$ współtworzenie ze wszystkimi uczniami kontraktu dotyczącego zasad przeciwdziałania dyskryminacji, segregacji;

$\rightarrow$ prowadzenie warsztatów na temat emocji, tożsamości, poczucia własnej wartości i godności, w których każdy uczeń mógłby wyrazić siebie i poznać innych;

$\rightarrow$ projektowanie procesu kształcenia $z$ wykorzystaniem nauki przez współpracę oraz realizowanie zajęć wzmacniających więzi między uczniami, czego dobrym przykładem może być projekt tutoringu rówieśniczego (Sajdera 2016), a także elementy zmodyfikowanego programu "Big Brothers Big Sisters of Poland" ${ }^{\text {, }}$ który mógłby wykorzystywać potencjał starszych uczniów tej samej szkoły lub szkoły wyższego szczebla;

$\rightarrow$ inicjowanie spotkań z rodzicami i uczniami, umożliwiających prezentację różnic i podobieństw wynikających z "odmienności”, co stanowiłoby podstawę budowania zrozumienia i akceptacji dla każdego dziecka.

Sukces pracy w grupie zróżnicowanej wiąże się ze zmianą stylu kierowania nauczaniem/uczeniem się i przejściem od modelu autokratycznego do demokratycznego, opartego na przywództwie (nauczyciel jako lider), partycypacji i poszanowaniu każdego uczestnika tego procesu. Powodzenie zmiany zależy od indywidualnych predyspozycji związanych z wrażliwością na drugiego człowieka, z szacunkiem i akceptacją 
osób z odmiennymi poglądami, osobowościami, cechami charakteru oraz różnymi możliwościami i ograniczeniami rozwojowymi. Jeśli naszym działaniom towarzyszyć będzie dostrzeganie i zrozumienie, że każdy człowiek jest indywidualną jednostką, posiadającą własną świadomość, określone cechy osobowości, predyspozycje, zdolności, wiedzę, doświadczenia i kompetencje, to stworzymy podstawy efektywnego zarządzania edukacyjną różnorodnością.

\section{Pozyskanie}

Kolejnym ważnym elementem pracy w grupie zróżnicowanej jest pozyskanie każdego ucznia jako aktywnego autora własnego procesu uczenia się. Zadanie to samo w sobie jest trudne do zrealizowania w standardowym zespole klasowym i wydaje się jeszcze większym wyzwaniem w grupie heterogenicznej pod względem indywidualnych umiejętności i możliwości uczenia się. Pomocne w projektowaniu działań może być uświadomienie sobie czynników związanych z organizacją procesu nauczania/uczenia się, które sprzyjają rozwojowi jednostkowemu i integrowaniu zespołu. Jedną z propozycji jest zastosowanie opisanego szeroko w literaturze programu TARGET (Brophy 2007, s. 40-43):

\begin{tabular}{|c|c|c|}
\hline $\mathbf{T}$ & $\begin{array}{l}\text { (task) } \\
\text { zadanie }\end{array}$ & $\begin{array}{l}\text { zróżnicowanie czynności dydaktycznych w taki sposób, } \\
\text { aby wewnętrznie angażowały ucznia do pracy, konstruowanie } \\
\text { czynności atrakcyjnych emocjonalnie i poznawczo, } \\
\text { indywidualizacja zadań i stopnia ich trudności }\end{array}$ \\
\hline A & $\begin{array}{l}\text { (authority) } \\
\text { autorytet }\end{array}$ & $\begin{array}{l}\text { dzielenie „władzy” w projektowaniu pracy ucznia, pozostawienie mu } \\
\text { swobody i tworzenie okazji do decydowania o tym, co i jak ma robić, } \\
\text { uznanie dla zróżnicowanych sposobów uczenia się }\end{array}$ \\
\hline $\mathbf{R}$ & $\begin{array}{l}\text { (reco- } \\
\text { gnition) } \\
\text { uznanie }\end{array}$ & $\begin{array}{l}\text { uznanie okazywane każdemu uczniowi, który czyni postępy na drodze } \\
\text { do indywidualnie wyznaczonych celów, pochwały (poza forum publicz- } \\
\text { nym) w ramach rozmowy skoncentrowanej na dziecku i jego pracy }\end{array}$ \\
\hline G & $\begin{array}{l}\text { (grouping) } \\
\text { grupowa- } \\
\text { nie }\end{array}$ & $\begin{array}{l}\text { organizowanie pracy w parach lub w małych grupach w celu społecz- } \\
\text { nego konstruowania wiedzy, podział na podzespoły uwzględniający } \\
\text { więzy koleżeńskie, wspólne zainteresowania i czynniki inne niż poziom } \\
\text { osiągnięć }\end{array}$ \\
\hline E & $\begin{array}{l}\text { (evalu- } \\
\text { ation) } \\
\text { ocenianie }\end{array}$ & $\begin{array}{l}\text { ocenianie kształtujące, wykorzystanie urozmaiconych narzędzi oceny } \\
\text { do dostarczenia uczniowi informacji na temat jego indywidualnych } \\
\text { postępów w pracy (np. portfolio) }\end{array}$ \\
\hline $\mathbf{T}$ & (time) czas & $\begin{array}{l}\text { akceptowanie i wyrażanie zgody na wydłużenie czasu pracy w związku } \\
\text { z indywidualnymi potrzebami, uelastycznienie zajęć dydaktycznych } \\
\text { przez realizację projektów dających większą swobodę w organizowa- } \\
\text { niu czasu i pracy }\end{array}$ \\
\hline
\end{tabular}

Źródło: Opracowanie własne na podstawie: Jere Brophy (2007). 
W procesie budowania współpracy wewnątrz zespołu jednym z ważniejszych elementów procesu TARGET jest świadome wykorzystanie działań w zakresie grupowania, czyli uczenia się kooperatywnego. Zakłada się tu stosowanie procedur, które polegają na udzielaniu sobie wzajemnej pomocy podczas nauki w małych grupach na podstawie pięciu elementów: pozytywnej współzależności, interakcji twarzą w twarz, indywidualnej odpowiedzialności za uczenie się zadanego materiału, umiejętności współpracy oraz przetwarzania grupowego (Dembo 1997).

\section{Zmienianie}

Ważnym elementem procesu edukacyjnego jest zmiana zachodząca w ujęciu zarówno jednostkowym, jak i społecznym. Uczenie się w warunkach zmiany oznacza współwystępowanie w tym procesie „trudu i okazji". Rolą dorosłych jest odpowiedzialne utrzymywanie równowagi między jednym i drugim elementem, aby dziecko, podejmując działania, mogło odnieść sukces. Zmiana zatem wiąże się często z rozstaniem z wcześniejszymi przekonaniami i przyzwyczajeniami. W przypadku nauczycieli może ona dotyczyć poczucia sprawstwa w pracy z grupą zróżnicowaną i uznania, że różnorodność może być siłą rozwojową dla wszystkich uczestników procesu edukacyjnego. Uczniowie powinni z kolei stawać się samodzielni i odpowiedzialni za własną pracę oraz traktować indywidualne możliwości i ograniczenia nie jako czynnik hamujący, ale wyznaczający i wzmacniający obszary nowego poznania oraz samorozwoju w zmieniającej się rzeczywistości szkolnej czy społecznej.

Podsumowując te rozważania, można zgodzić się z Ireną Dzierzgowską (2007), że uczeń powinien stykać się z różnorodnością i bogactwem świata. To założenie przyświeca również teoretycznym podstawom edukacji włączającej, które wskazują, że szkoła powinna integrować różne dzieci, niezależnie od ich warunków fizycznych, intelektualnych, socjalnych, językowych itp. Zgodnie z tą ideą w tej samej klasie mogą i powinny z powodzeniem uczyć się dzieci utalentowane, $z$ trudnościami w nauce, dzieci uchodźców, pochodzące z rodzin bezrobotnych, z mniejszości narodowych, z grup nierównych szans czy z tzw. marginesu społecznego. Tego typu szkoły, dbające o potrzeby indywidualne i wymiar społeczny, mogą przyczynić się do właściwego kształcenia wszystkich uczniów, a równocześnie do zmian postaw dyskryminacyjnych i tworzenia społeczeństwa otwartego. 


\section{Jakie wsparcie? Współpraca nauczycieli, specjalistów, innych instytucji „pozaoświatowych”}

Powodzenie edukacji włączającej zależy od zaangażowania i przygotowania kadr zarządzających, nadzorujących oświatę i realizujących procesy edukacyjne. Istotne jest zatem budowanie platformy współpracujących instytucji i ludzi: dyrektorów, nauczycieli oraz pracowników przedszkoli, szkół, placówek oświatowych, ale również osób z instytucji, którym one podlegają: wydziałów edukacji, kuratoriów oświaty i wychowania. Przestawienie się na myślenie o szkole dla wszystkich wymaga zrozumienia uwarunkowań edukacji włączającej w ramach polityki oświatowej. Rzeczywista realizacja tej idei zależy od postaw osób zarządzających wobec niej - od ich aprobaty i zrozumienia wypływających z wiedzy na temat tego zagadnienia. Wspieranie nauczycieli i szkół w tworzeniu warunków, w których wspólna edukacja będzie korzystna dla każdego ucznia, wymaga zrozumienia złożonych uwarunkowań procesu, zróżnicowania wsparcia szkół, placówek edukacyjnych, w zależności od ich potrzeb. Ponadto - odpowiedniego nastawienia oraz umiejętności i chęci takiej interpretacji zapisów prawa, by maksymalnie ułatwiać, wspierać, a w rezultacie zachęcać każdą placówkę do podjęcia działań włączających (Jachimczak 2018).

Żeby edukacja włączająca mogła być z sukcesem realizowana w polskich szkołach, konieczne jest przekonanie do niej zatrudnionych w nich osób, a także wyposażenie ich w umiejętności z zakresu wsparcia udzielanego każdemu dziecku oraz osobie dorosłej, która uczestniczy w procesie jego kształcenia. Bardzo często bywa tak, że mimo zapisów formalnych dotyczących wspomagania ucznia ze specjalnymi potrzebami, które powinny być stosowane w każdej szkole, dopiero pojawienie się dziecka "specjalnego" zwraca na nie uwagę. Dlatego ważne jest odpowiednie przygotowanie wszystkich pracowników przedszkola i szkoły, a także dorosłych opiekunów prawnych ucznia, w zakresie: uznania prawa dziecka do zaspokajania własnych potrzeb, przyczyn pojawiania się trudności w procesie dydaktycznym, danego rodzaju niepełnosprawności w kontekście bliskich i dalekich celów związanych z funkcjonowaniem człowieka, udzielania adekwatnego wsparcia w sytuacji szkolnej w zależności od występujących problemów.

Tony Booth i Mel Ainscow (2002, s. 10, 15), opracowując Indeks dla włączania. Rozwój kształcenia i uczestnictwa w szkołach, wskazali, 
że rozwój placówki z punktu widzenia włączania nie może być procesem mechanicznym. Wprowadzane zmiany powinny bowiem wynikać z budowania powiązań między wartościami, emocjami oraz czynami, stanowić rezultat pogłębionej refleksji, analizy i planowania działań. Sukcesu rozwoju szkoły upatrywali oni w zaangażowaniu dyrektora i pracowników. Rekomendowali powołanie zespołu do spraw planowania rozwoju szkoły (w kierunku placówki włączającej), którego członkami mieliby być koordynatorzy wsparcia w zakresie uczenia się (pedagog, pedagog specjalny, psycholog, nauczyciel wspomagający) oraz przedstawiciele rodziców (opiekunów), uczniów, kadry zarządzającej oraz pracowników spoza kadry nauczycielskiej. Proponowany projekt działań zakładał elastyczność przy powoływaniu zespołu i podkreślał możliwość dopełniania jego składu innymi specjalistami, wnoszącymi nowe zasoby sprzyjające poprawieniu jakości kształcenia w grupach zróżnicowanych. Autorzy Indeksu dostrzegli również zróżnicowanie placówek pod względem wielkości i składu, a co za tym idzie, wskazywali, że grupy koordynujące działania włączające (index co-ordinating) również mogą się różnić w poszczególnych szkołach.

Podobne rozwiązania dotyczące wsparcia szkół angielskich w zakresie edukacji włączającej prezentowała Pearl Barnes (2008). Badała ona opinie specjalnych koordynatorów potrzeb edukacyjnych (SENCos) i rodziców na temat racjonalności i efektywności współpracy pracowników szkół z wieloma instytucjami zewnętrznymi zajmującymi się wspomaganiem rozwoju dzieci. Przeprowadzone wywiady zawierały wysokie oceny dotyczące współdziałania placówek specjalistycznych ze szkołami włączającymi w zakresie projektowania działań dostosowanych do indywidualnych potrzeb dziecka. Oceniano, że praca instytucji zewnętrznych była czynnikiem umożliwiającym i wzmacniającym edukację włączającą poprzez wczesną i holistyczną ocenę indywidualnych potrzeb dziecka. Pozwalała ona również identyfikację barier uniemożliwiających osiągnięcie przez dziecko sukcesu szkolnego. Mimo że nie określono wspólnego sposobu działania na rzecz edukacji włączającej, panowała powszechna zgoda, że podejście oparte na pracy zespołowej bezpośrednio w szkołach oraz w innych instytucjach, było skuteczne w zakresie wsparcia zarówno pojedynczych uczniów, jak i placówek oświatowych.

Ponieważ Polska znajduje się w momencie wprowadzania zmian w systemowym podejściu do uczniów ze specjalnymi potrzebami, istot- 
ne wydaje się zaprojektowanie wsparcia dla przedszkoli i szkół. Celem tego wielospecjalistycznego wspomagania byłoby przeciwdziałanie narażaniu ucznia na niepowodzenia szkolne z powodu m.in.: braku specjalistycznej pomocy czy niewłaściwych postaw nauczycieli i rówieśników w stosunku do niego. Może się to przekładać na nieadekwatne oceny własnych możliwości, nierealne wizje własnej przyszłości, zbyt wysokie lub niskie oczekiwania społeczne wobec niego lub samoograniczenie z wizją automarginalizacji w tle.

Właściwe zaspokajanie specjalnych potrzeb edukacyjnych w szkołach, poza wspomnianym wcześniej kształceniem wszystkich nauczycieli, wymaga zatrudnienia specjalistów. Główny zespół odpowiedzialny za edukację włączającą powinien składać się, tak jak w projekcie Bootha i Ainscowa, z pedagoga, psychologa, pedagoga specjalnego będącego koordynatorem włączania oraz z innych specjalistów zatrudnionych w szkole - zgodnie z zapotrzebowaniem - do indywidualnego lub zespołowego wspomagania uczniów (pedagodzy, asystenci, terapeuci specjalistyczni). Dodatkowym wsparciem mógłby służyć specjalista, którego autorzy projektu (Booth, Ainscow 2002, s. 16) nazywają „osobą krytyczną". Powinien to być ktoś spoza szkoły, kto zna dość dobrze placówkę, jest kompetentny. Mając zaufanie grupy (nauczycieli, uczniów i rodziców), angażowałby się czasowo w rozwiązywanie problemów przekraczających możliwości środowiska szkolnego. Taką rolę mógłby odgrywać ekspert zatrudniony w instytucji wsparcia specjalnych potrzeb edukacyjnych, świadczącej usługi zamawiane przez szkoły i przedszkola.

Niezależnie od tego, że zmiany związane z wprowadzeniem edukacji włączającej nie mają i nie powinny zakładać likwidacji żadnej ścieżki kształcenia, należy zadbać o to, aby w ramach każdej z nich dziecko otrzymywało wsparcie i pomoc specjalistyczną na tym samym poziomie. Odpowiedzialna współpraca instytucji (przedszkoli/szkół specjalnych, integracyjnych, ogólnodostępnych, poradni psychologiczno-pedagogicznych, ośrodków wczesnego wspomagania, organizacji pozarządowych działających na rzecz uczniów ze SPE) i potencjalnych nowych podmiotów pozwoli zweryfikować w praktyce zmiany preferencji w zakresie wyboru rodzaju szkoły - na włączającą - przez dzieci i ich rodziców. Do tego czasu nie należy ograniczać możliwości edukacyjnych. To dobra praktyka, a nie decyzja administracyjna, powinna być kryterium rozwoju rozwiązań w oświacie. Tylko takie podejście akceptowane jest przez 
specjalistów z zakresu edukacji włączającej, a także przez bezpośrednio zainteresowanych uczniów, ich rodziców i nauczycieli. I tylko ono jest zgodne z zasadą ograniczonego zaufania, do której każdy odbiorca usług, również edukacyjnych, ma prawo się stosować. 


\subsection{Uczeń w edukacji włączającej}

"Uczeń w edukacji włączającej" to zagadnienie szerokie i złożone, musi więc być rozpatrywane na kilku równoległych płaszczyznach. W niniejszym rozdziale omówiono szczegółowo polskie regulacje prawne, które wprost (lub pośrednio) odnoszą się do obszaru kształcenia uczniów ze specjalnymi potrzebami edukacyjnymi. Podjęto kwestię diagnozy w edukacji włączającej (m.in. obszarów, metod oraz narzędzi badania) oraz założenia projektowania uniwersalnego w nauczaniu (UDL) i możliwe sposoby jego realizacji na lekcjach. Zapoznać się można z metodologią kształtowania pozytywnych postaw wobec dziecka ze specjalnymi potrzebami w grupie rówieśniczej, a także z możliwościami wykorzystania oceniania kształtującego w edukacji. Rozdział zamykają rozważania na temat jednego z najtrudniejszych etapów rozwojowych młodych ludzi - przejścia z edukacji do rynku pracy.

\section{Słowa kluczowe:}

\section{prawo oświatowe}

diagnoza

projektowanie uniwersalne w nauczaniu (UDL)

ocenianie kształtujące

współpraca rówieśnicza

przejście do rynku pracy 


\subsection{Student in inclusive education}

'Student in inclusive education' is a broad and complex issue, so it must be considered on several parallel levels. This chapter discusses in detail Polish legal regulations which directly (or indirectly) refer to the area of education of children with special educational needs. The authors presents identification of educational needs in inclusive education (including areas, methods and research tools) and the assumptions of universal design for learning (UDL) and possible ways of its implementation in the classroom. The methodology of shaping positive basis for a child with special needs in the peer group, as well as the possibilities of using formative assessment in education are presented. The chapter ends with reflections on one of the most difficult development stages of young people - the transition from education to the labor market.

\section{Keywords:}

\section{education law}

diagnosis

universal design for learning (UDL)

formative assessment

peer cooperation 


\title{
2.4.1. Diagnoza - obszary, sposoby, narzędzia
}

\author{
Marzenna Czarnocka
}

\section{Podstawowe założenia - w kierunku diagnozy funkcjonalnej}

Podczas rozważania kwestii diagnozy w praktyce edukacyjnej szczególnie istotne wydaje się znalezienie odpowiedzi na pytania: „Dlaczego jest ona ważna?", „W jakim celu jest prowadzona?”, ,Czemu ma służyć rozpoznanie, kto i jaki sposób będzie wykorzystywał jego wyniki?". Przyjęcie takiej perspektywy pozwala uświadomić sobie złożoność i wielość aspektów diagnozy - z jednej strony z uwagi na potrzebę rozpoznania indywidualnych potrzeb i spersonalizowania projektowania procesu uczenia się (zarówno dla osób z deficytami w rozwoju, jak i uzdolnionych), z drugiej w związku z postulatem zapewnienia odpowiednich warunków edukacji wszystkim uczniom w szkole, z uwzględnieniem ich zróżnicowanego potencjału. Podejście do diagnozy z perspektywy założeń edukacji włączającej wymaga zatem szerokiego, systemowego spojrzenia zarówno na proces, jak i na efekt postępowania diagnostycznego oraz na sposób wykorzystania jego wyników.

Diagnoza powinna obejmować pełny zakres uwarunkowań funkcjonowania ucznia, z uwzględnieniem możliwości dostosowania środowiska do jego specjalnych potrzeb (Krakowiak 2017, s. 14). W związku z tym musi zawierać w sobie również element prognostyczny, tj. stanowić punkt wyjścia do planowania działań wspierających rozwój dziecka i zapewniających mu pełną aktywność w procesie uczenia się. W takim rozumieniu diagnoza edukacyjna integruje zróżnicowane podejścia i działania, biorąc pod uwagę wielorakie potrzeby wszystkich uczniów, a w perspektywie mając cel, jakim jest pełne wykorzystanie ich potencjału w nabywaniu kompetencji i współuczestnictwie w życiu szkoły. 
Rysunek 1. Zintegrowany model diagnozy w edukacji włączającej

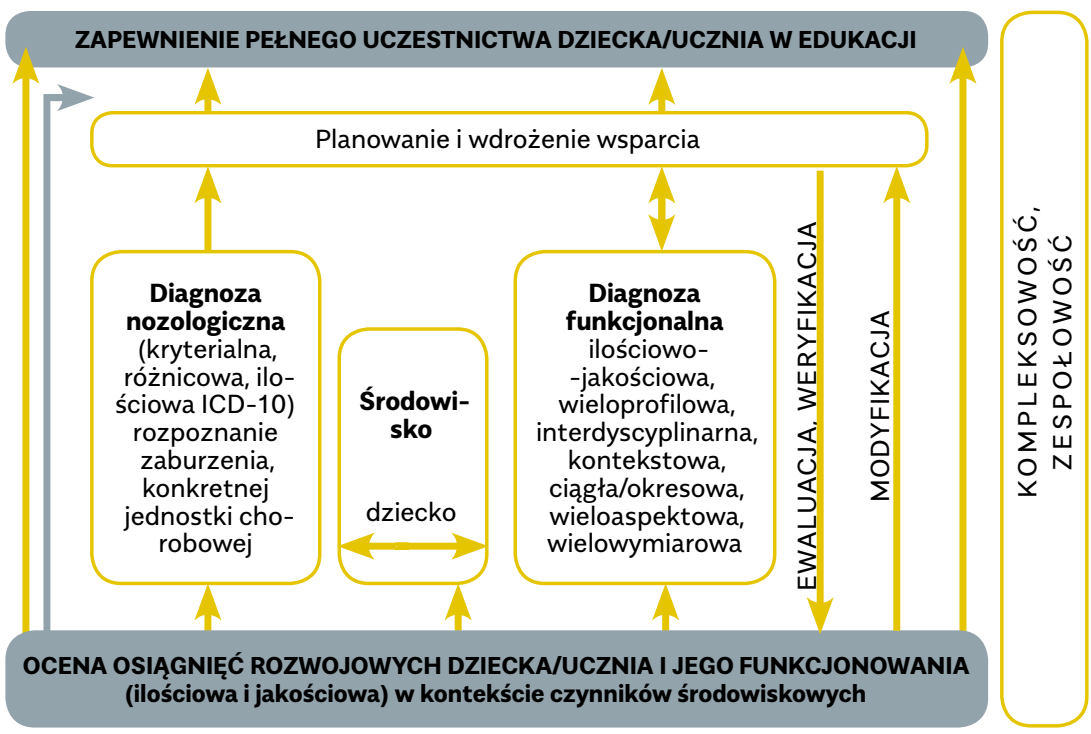

Źródło: Opracowanie własne na podstawie: R. Piotrowicz, Wieloprofilowa diagnoza małego dziecka. Wskazania dla specjalistów i rodziców małych dzieci z symptomami zaburzeń rozwojowych.

Diagnoza ukierunkowana na projektowanie procesu dydaktycznego i planowanie działań wspierających uczniów jest dynamiczna, wielowymiarowa, wieloetapowa i transdyscyplinarna. Łączy w sobie:

$\rightarrow$ ocenę kliniczną,

$\rightarrow$ ocenę psychologiczno-pedagogiczną,

$\rightarrow$ ocenę logopedyczną,

$\rightarrow$ charakterystykę społeczną,

$\rightarrow$ diagnozę funkcjonalną.

Diagnoza funkcjonalna jest sumą poprzednich etapów, a jednocześnie kolejną częścią składową ciągu działań, którego wynikiem powinien być przejrzysty opis potrzeb ucznia i wykaz zadań, jakie stoją przed zespołem specjalistów, rodziną, szkołą i najbliższym środowiskiem społecznym, w którym wychowuje się dziecko (Krakowiak 2017, s. 15).

Jest ona niezwykle przydatna w edukacji w związku z tym, że pozwala określić adekwatność zachowania dziecka w stosunku do wymagań oto- 
czenia i opisać funkcjonowanie procesów psychicznych odpowiedzialnych za regulację jego postępowania (Krasowicz-Kupis, Wiejak, Gruszczyńska 2015 , s. 12). Istotne jest rozpoznanie zarówno problemów i deficytów, jak i mocnych stron dziecka. Diagnoza funkcjonalna umożliwia przy tym zintegrowanie różnych modeli diagnostycznych i podejść teoretycznych w gromadzeniu i wykorzystaniu możliwie szerokiej wiedzy o dziecku i jego funkcjonowaniu. Oznacza to konieczność odejścia od spojrzenia na potrzeby ucznia wyłącznie z perspektywy jego dysfunkcji. Diagnoza realizowana w celu optymalnego zaangażowania i uczestnictwa uczniów w procesie dydaktycznym wpisuje się w biopsychospołeczny model funkcjonowania , bazujący na analizie ich indywidualnej sytuacji w wymiarze psychicznych, biologicznych i społecznych czynników, jakie mają na nich wpływ. Uwzględnia bariery i ograniczenia utrudniające dzieciom aktywne i efektywne realizowanie zadań rozwojowych oraz edukacyjnych, a tym samym zdobywanie kompetencji przydatnych w późniejszym życiu. Podejście biopsychospołeczne to fundament diagnozy funkcjonalnej.

Diagnoza funkcjonalna ${ }^{2}$ to wieloaspektowy proces rozpoznawania zasobów dziecka, trudności, z jakimi się zmaga, oraz czynników środowiskowych oddziałujących na nie, uwzględniający analizę funkcjonowania (opartą na klasyfikacji ICF, wiedzy o kamieniach milowych w rozwoju), diagnozę kryterialną (opartą na klasyfikacji ICD) oraz adekwatny i podlegający stałej ewaluacji program wsparcia.

Uwzględnia ona:

$\rightarrow$ holistyczne ujęcie człowieka, w tym charakterystykę jego funkcji psychicznych oraz funkcjonowanie w obszarach: fizyczno-motorycznym, emocjonalnym (w tym przywiązania), społecznym, moralnym, osobowościowym, poznawczym, rozwoju mowy, języka i komunikacji;

Model biopsychospołeczny uwzględniony w Międzynarodowej Klasyfikacji Funkcjonowania, Niepełnosprawności i Zdrowia ICF (Światowa Organizacja Zdrowia 2001), który koncentruje się na funkcjonowaniu jednostki w określonej dziedzinie, jest postrzegany jako „interakcja lub związek między stanem zdrowia a czynnikami kontekstowymi (tzn. czynnikami środowiskowymi i osobowymi). Zachodzi tu dynamiczna interakcja - interwencje na jednym poziomie mogą potencjalnie modyfikować inne powiązane z nimi elementy" - Międzynarodowa Klasyfikacja Funkcjonowania, Niepełnosprawności i Zdrowia ICF, 2001, s. 19, bit.ly/2ERzK6c [dostęp: 6.06.2019]. kształcenia uczniów ze specjalnymi potrzebami edukacyjnymi, który został powołany przez Ministra Edukacji Narodowej zarządzeniem nr 39 z dnia 13 października 2017 r. 
$\rightarrow$ wykorzystanie informacji pochodzących z różnych źródeł (nauczyciele, rodzice, opiekunowie prawni, specjaliści przedszkolni i szkolni, terapeuci, pracownicy poradni psychologiczno-pedagogicznych, a także samo dziecko $w$ zakresie odpowiednim do wieku i poziomu rozwoju) do uzyskania obiektywnego obrazu funkcjonowania ucznia i jego sytuacji życiowej;

$\rightarrow$ skorelowanie działań poszczególnych osób i instytucji udzielających wsparcia;

$\rightarrow$ połączenie wiedzy z zakresu klinicznego obrazu problemu oraz działania osoby w codziennych sytuacjach (ICF);

$\rightarrow$ określenie wpływu czynników kontekstowych na dziecko, w tym zasobów i barier w środowisku (rodzina, przedszkole, szkoła, środowisko lokalne itp.).

Zrozumienie sposobu funkcjonowania ucznia pozwala zastosować adekwatne działania pomocowe. Diagnoza jest bazą do planowania, organizowania i realizowania działań wspierających rozwój i funkcjonowanie dziecka, w tym polegających na minimalizowaniu lub likwidacji barier środowiskowych.

\section{Obszary diagnozy w wymiarze włączającej szkoły}

Inkluzja zaczyna się od uznania tego, że każdy z uczniów jest jedyny w swoim rodzaju (Booth, Ainscow 2002, s. 3). Zapewnienie wszystkim odpowiedniej jakości edukacji, w tym rzeczywistego włączenia i równego dostępu, wymaga zatem dostrzeżenia w zróżnicowanym zespole indywidualności każdej osoby, zidentyfikowania jej potrzeb oraz trudności, z jakimi może się spotkać. W edukacji włączającej, rozumianej jako swoisty ekosystem wzajemnie oddziałujących na siebie czynników i procesów, implikuje to konieczność całościowego podejścia do diagnozy i oceny potrzeb uczniów. Diagnoza ma służyć przede wszystkim zapewnieniu w szkole warunków umożliwiających każdemu współuczestniczenie $w$ procesie uczenia się i wychowania. Wiąże się to ze zmianą podejścia skoncentrowanego jedynie na deficytach i trudnościach na rzecz wielowymiarowego i holistycznego gromadzenia informacji o biologicznych, poznawczych i społeczno-emocjonalnych aspektach funkcjonowania dziecka oraz na czynnikach w środowisku przedszkolnym lub szkolnym, które mogą je wspierać lub stanowić barierę w jego aktywności i uczestniczeniu. 
Rysunek 2. Obszary działań diagnostycznych w przedszkolu/szkole

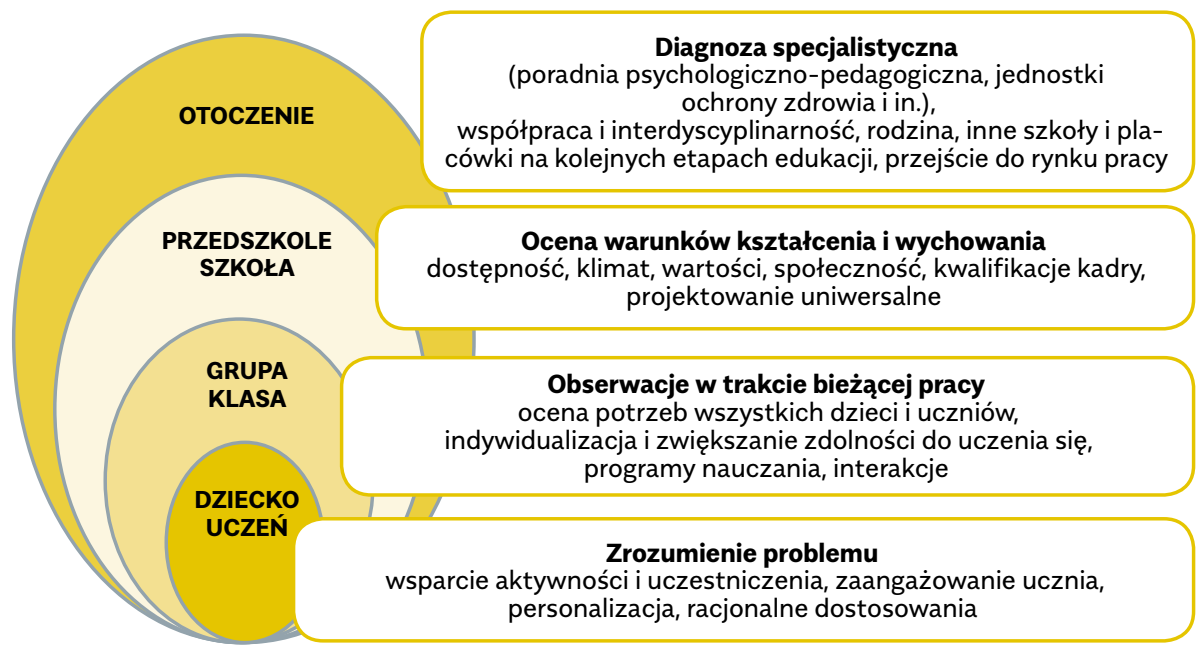

Źródło: Opracowanie własne na podstawie: Europejska Agencja (2017b).

Obszary te wzajemnie się przenikają. Czynniki występujące w środowisku oddziałują na siebie $z$ różnym nasileniem $w$ toku rozwoju i edukacji dziecka. Mogą również implikować określone skutki dla jego funkcjonowania, a w konsekwencji wywoływać różnorodne, zmieniające się w czasie potrzeby. Oznacza to, że diagnoza nie może być działaniem jednorazowym. Musi być realizowana w ścisłym powiązaniu z dynamicznym rozwojem dziecka, ze zmianami sytuacji oraz warunków w jego otoczeniu. Działania diagnostyczne podejmowane w przedszkolu, szkole i innego rodzaju placówce mogą wymagać, w zależności od potrzeb ucznia, współdziałania kilku jednostek systemu oświaty oraz współpracy podmiotów $z$ różnych sektorów. W proces ten na różnych etapach powinni być zaangażowani (w zakresie swoich kompetencji) nauczyciele, specjaliści i inni pracownicy szkoły, specjaliści z poradni psychologiczno-pedagogicznych oraz innych instytucji wspomagających instytucje edukacyjne. Ważną funkcję pełnią w nim również rodzice oraz - w miarę potrzeb, możliwości, a także $w$ formie dostosowanej do wieku i poziomu funkcjonowania - dzieci/uczniowie.

Rozpoznanie musi dotyczyć możliwie szerokiej perspektywy, a jednocześnie koncentrować się na sytuacji poszczególnych osób. Żeby 
działania terapeutyczne, usprawniające, kompensacyjne i korekcyjne oraz wspierające motywację do uczenia się były skuteczne, muszą mieć one charakter indywidualny i skupiać się na osobie oraz na jej relacjach ze środowiskiem społecznym, w którym żyje i rozwija się. Celem diagnozy powinno być jak najpełniejsze poznanie barier i utrudnień, które zaburzają harmonię tych relacji i przyczyniają się do zahamowania integralnego rozwoju ucznia - biologicznego, poznawczego, społeczno-emocjonalnego i moralno-duchowego (Krakowiak 2017, s. 13).

Obszary diagnozy powinny obejmować zwłaszcza ${ }^{3}$ :

$\rightarrow$ rozpoznanie u dziecka dysharmonii rozwojowych, w tym trudności uwarunkowanych stanem zdrowia,

$\rightarrow$ indywidualne możliwości psychofizyczne,

$\rightarrow$ analizę i ocenę gotowości dziecka do podjęcia nauki,

$\rightarrow$ trudności w uczeniu się i ocenę ich skutków dla funkcjonowania dziecka,

$\rightarrow$ przyczyny niepowodzeń edukacyjnych lub trudności w funkcjonowaniu, deficyty kompetencji i zaburzenia sprawności językowych,

$\rightarrow$ ryzyko wystąpienia specyficznych trudności w uczeniu się,

$\rightarrow$ mocne strony, predyspozycje, zainteresowania i uzdolnienia uczniów,

$\rightarrow$ indywidualne potrzeby rozwojowe i edukacyjne wynikające $z$ dokonanego rozpoznania, uwzględniające:

- dostosowanie wymagań edukacyjnych wynikających z realizowanego przez nauczyciela programu nauczania do indywidualnych potrzeb ucznia,

- zakres i charakter wsparcia ze strony dodatkowo zatrudnionej kadry,

- potrzebę realizacji wybranych zajęć indywidualnych lub prowadzonych w mniejszej grupie,

$\rightarrow$ czynniki środowiskowe wpływające na funkcjonowanie dziec$k a, w$ tym bariery i ograniczenia utrudniające funkcjonowanie (w środowisku szkoły i klasy oraz w otoczeniu), udzielania i organizacji pomocy psychologiczno-pedagogicznej w publicznych przedszkolach, szkołach i placówkach (Dz.U. z 2017 r. poz. 1591); Rozporządzeniu Ministra Edukacji Narodowej z dnia 9 sierpnia 2017 r. w sprawie warunków organizowania kształcenia, wychowania i opieki dla dzieci i młodzieży niepełnosprawnych, niedostosowanych społecznie i zagrożonych niedostosowaniem społecznym (Dz.U. z 2017 r. poz. 1578 ze zm.); Rozporządzeniu Ministra Edukacji Narodowej z dnia 3 sierpnia 2017 r. w sprawie oceniania, klasyfikowania i promowania uczniów i słuchaczy w szkołach publicznych (Dz.U. z 2017 r. poz. 1534). 
$\rightarrow$ trudności w zakresie włączenia ucznia w zajęcia przedszkolne lub szkolne,

$\rightarrow$ predyspozycje w zakresie wyboru kierunku kształcenia i zawodu.

Systemowe myślenie o potrzebach uczniów nie może pomijać analizy, czy i w jakim zakresie pojawiające się trudności korelują z warunkami, w jakich funkcjonuje dziecko, sprawdzenia, czy trudności te dotyczą również innych uczestników życia szkoły (nauczyciele, inni uczniowie) oraz tego, jakie czynniki środowiskowe mogą mieć wpływ (pozytywny/negatywny) na ich pojawianie się. Integralnym elementem rozpoznania dokonywanego w szkole musi być oszacowanie dostępnych zasobów w środowisku (kto i w jakim zakresie może wspierać dziecko, jakie czynniki mogą sprzyjać pokonywaniu trudności, co może wpłynąć na poprawę funkcjonowania ucznia). Brane pod uwagę musi być także ewentualne dostosowanie środowiska ucznia w celu efektywnego pokonywania trudności i wyeliminowania lub zminimalizowania czynników mogących mieć negatywny wpływ na jego zaangażowanie w proces uczenia się. Ważnym aspektem jest również analiza warunków kształcenia i wychowania w zakresie dostępności i kultury organizacyjnej placówki edukacyjnej (środowisko fizyczne, wartości, klimat, przywództwo) oraz możliwości zapewnienia profesjonalnie przygotowanej kadry (odpowiednia struktura zatrudnienia, kwalifikacje, ciągłość doskonalenia zawodowego w różnych formach). Obszar zainteresowania szkoły w procesie diagnozy powinien również uwzględniać jej otoczenie i zasoby lokalnego środowiska.

\section{Przebieg procesu diagnozy}

Gwarancją realnego włączenia wszystkich uczniów na zasadach równości praw jest właściwa identyfikacja ich potrzeb. Powinna być ona przeprowadzana możliwie najwcześniej, co zwiększa szanse na rozwijanie potencjału dzieci i przezwyciężenie trudności. Szczególną rolę odgrywają w tym zakresie nauczyciele, którzy najszybciej i najtrafniej mogą zaobserwować pierwsze symptomy kłopotów ucznia lub dostrzec jego szczególne predyspozycje. Ważnym ogniwem systemowych rozwiązań są również szkolni specjaliści, których zadaniem jest wspieranie nauczycieli i innych specjalistów w procesie rozpoznawania potrzeb uczniów oraz w udzielaniu pomocy psychologiczno-pedagogicznej im oraz ich rodzicom. 
Rysunek 3. Przebieg działań diagnostycznych

\section{Schemat działań diagnostycznych podejmowanych w szkole i w poradni psychologiczno-pedagogicznej (PPP)}

I etap

Ocena potrzeb

dziecka w przed-

szkolu lub szkole rozpoznanie dokonane

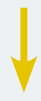

Poziom 1

Poziom 2

Poziom 3 zespół-nauczyciel, specjalista, wychowawca, rodzice (uczeń, inne osoby) przez nauczyciela

ocena warunków kształcenia i wychowania w przedszkolu, w szkole, grupie lub klasie, bieżąca obserwacja funkcjonowania dzieci i uczniów, sprawdzanie ich postępów w nabywaniu wiedzy i umiejętności w odniesieniu do celów określonych w programach wychowania przedszkolnego i programach nauczania, a także w kontekście indywidualnych celów edukacyjnych i rozwojowych

\begin{abstract}
nauczyciel i rodzice (uczeń)

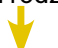

udzielenie dziecku wsparcia podczas bieżącej pracy
\end{abstract}

\section{ustalenie zakresu pomocy udzielanej dziecku w bieżącej pracy}

okresowa ocena efektywności działań dokonywana przez nauczyciela (rodziców, ucznia) - decyzja o zakończeniu pomocy lub ustalenie zakresu pomocy udzielanej dziecku, modyfikacja, uzupełnienie dotychczasowych form wsparcia

okresowa ocena efektywności działań dokonywana przez zespół-modyfikacja, kontynuowanie dotychczasowych form wsparcia, decyzja o zakończeniu pomocy lub o diagnozie w PPP

Na każdym poziomie nauczyciele i specjaliści szkolni mogą podjąć współpracę ze specjalistami z PPP, w zależności od potrzeb i rozpoznanego problemu ucznia (nasilenie trudności, brak spodziewanych efektów wsparcia). W związku z tym decyzja o zaangażowaniu poradni i podjęciu specjalistycznej diagnozy może być podjęta równolegle z bieżącym wsparciem ucznia w szkole, prowadzonym do czasu uzyskania wyników diagnozy specjalistycznej.

Il etap
Diagnoza specjali-
styczna w poradni
psychologiczno-
-pedagogicznej
III etap

diagnoza w PPP - specjaliści, rodzice (uczeń), informacje od nauczycieli, informacje z innych ośrodków diagnostycznych zespół-nauczyciel, specjalista, wychowawca, rodzice (uczeń), specjalista z PPP

\section{PPP wydaje orzeczenie lub opinię}

\author{
wsparcie organizowane w przedszkolu/szkole \\ na podstawie dokumentu wydanego przez PPP \\ ustalenie zakresu pomocy udzielanej dziecku \\ przez szkołę i (lub) we współpracy z poradnią \\ psychologiczno-pedagogiczną
} -pedagogicznych w zakresie postępowania diagnostycznego określone w: Rozporządzeniu Ministra Edukacji Narodowej z dnia 9 sierpnia 2017 r. w sprawie zasad udzielania i organizacji pomocy psychologiczno-pedagogicznej w publicznych przedszkolach, szkołach i placówkach (Dz.U. poz. 1591); Rozporządzeniu Ministra Edukacji Narodowej z dnia 7 września 2017 r. w sprawie orzeczeń i opinii wydawanych przez zespoły orzekające działające w publicznych poradniach psychologiczno-pedagogicznych (Dz.U. poz. 1743); Rozporządzeniu Ministra Edukacji Narodowej z dnia 1 lutego 2013 r. w sprawie szczegółowych zasad działania publicznych poradni psychologiczno-pedagogicznych, w tym specjalistycznych (Dz.U. poz. 199 ze zm.). 
Istotnym warunkiem powodzenia działań podejmowanych na etapie I jest współpraca w zespołach nauczycielskich, wymiana doświadczeń, wspólne rozwiązywanie problemów, ale też możliwość korzystania z pomocy zewnętrznej, np. w formie konsultacji, grup wsparcia lub nauczycielskich sieci wsparcia i samokształcenia, realizowanych przez poradnie psychologiczno-pedagogiczne i placówki doskonalenia nauczycieli.

Koniecznym warunkiem skuteczności działań diagnostycznych w przedszkolu i szkole jest zbudowanie takiej kultury organizacyjnej, w której specjaliści będą udzielać wsparcia nie tylko uczniom, ale również nauczycielom i wychowawcom w zakresie rozpoznania potrzeb ich podopiecznych (poziom 2). Współpraca i wsparcie na tym poziomie, a także potwierdzenie skuteczności działań podjętych przez nauczyciela lub uzupełnienie ich o inne, możliwe do zastosowania w najbliższym środowisku ucznia (konkretne sposoby postępowania w klasie szkolnej, w grupie rówieśniczej), to elementy, które mogą zwiększyć skuteczność działania zarówno konkretnego nauczyciela, jak i całej szkoły, a także zapobiegać ewentualnym sytuacjom problemowym. Dostrzeżenie na tym etapie efektów odpowiednich dostosowań (wymiar środowiskowy) i udzielenie adekwatnych do potrzeb form wsparcia (wymiar osobowy) z pewnością wzmocni szkołę i przekona pracujących w niej nauczycieli lub specjalistów do tego, że mają oni realny wpływ na realizację przypisanych im zadań, a także możliwość skutecznego rozwiązywania problemów. Dobre praktyki i doświadczenia na tym etapie pozwolą szkołom lepiej radzić sobie w analogicznych sytuacjach w przyszłości.

Równie ważna jest współpraca z poradnią psychologiczno-pedagogiczną oraz z innymi podmiotami na II i III etapie postępowania z uwagi na wielość punktów widzenia, zwiększenie możliwości diagnostycznych szkoły oraz zobiektywizowanie wyników prowadzonego w niej rozpoznania, a w konsekwencji poszerzenie perspektywy w procesie oceny i planowania wsparcia dla uczniów.

\section{Sposoby oceny i narzędzia diagnozy}

Podstawą właściwego postępowania diagnostycznego jest odpowiedni dobór narzędzi badawczych. W przypadku diagnozy edukacyjnej wybór właściwej metody oznacza wypadkową jej celu (Czemu ma służyć i jak będą wykorzystane jej wyniki?), wiedzy i kompetencji diagnosty, przedmiotu pomiaru (Co i dlaczego chcemy mierzyć?) oraz czynników osobowych (kim jest osoba badana: określenie jej wieku, płci i innych 
czynników kulturowych) (Krasowicz-Kupis, Wiejak, Gruszczyńska 2015, s. 140).

W diagnozie psychologicznej wyróżnia się trzy główne metody diagnozowania: wywiad, obserwowanie zachowania i testowanie (Groth-Marnat 2003 [za: Stemplewska-Żakowicz 2008, s. 57]). Mogą one mieć zastosowanie w diagnozie funkcjonalnej, która łączy w ocenie badania ilościowe i jakościowe.

W podejściu ilościowym szczególne znaczenie przypisuje się narzędziom badawczym, które mają eliminować wpływ czynników zewnętrznych oraz subiektywną ocenę badacza. Do najczęściej stosowanych metod pomiarowych należą: kwestionariusze, testy, arkusze obserwacyjne oraz skale pomiarowe. W badaniach jakościowych, uwzględniających wymiar społeczny i kulturowy, stosuje się: metody projekcyjne, obserwację, wywiad, analizę dokumentów i wytworów działania, próby eksperymentalne, a także techniki oparte na komunikowaniu się z badanymi lub z osobami z ich otoczenia: wywiad, ankieta, rozmowa, spontaniczne wypowiedzi (Konarzewski 2000; Maszke 2008 [za: Panasiuk 2017, s. 48-49]) ${ }^{5}$.

Dobór odpowiedniego narzędzia diagnostycznego musi być dokonany na podstawie wiedzy i kompetencji diagnosty. W tym zakresie odpowiedzialność psychologa, pedagoga, logopedy czy nauczyciela nie ogranicza się jedynie do wyboru narzędzia, ale musi przede wszystkim uwzględniać (Krasowicz-Kupis, Wiejak, Gruszczyńska 2015, s. 140):

$\rightarrow$ adekwatność do celu badania (np. ocena gotowości szkolnej czy funkcjonowania ucznia w klasie lub określenie powodu trudności w uczeniu się) i wiążących się z tym decyzji (np. odroczenie obowiązku szkolnego, wybór ścieżki edukacyjnej, pogłębiona diagnoza, zakres wsparcia, rodzaj terapii),

$\rightarrow$ indywidualne cechy badanej osoby (wiek dziecka, poziom edukacyjny),

$\rightarrow$ merytoryczne stosowanie narzędzi - znajomość procedury badania oraz rozumienie znaczenia jej przestrzegania i umiejętność przeprowadzenia, umiejętność oceny odpowiedzi i obliczania wyników oraz ich prawidłowej interpretacji i analizy - świado- 
mość, że formułowane wnioski nie powinny wykraczać poza dane dotyczące trafności narzędzia (tzn. poza przedmiot pomiaru opisany w podręczniku do testu lub w publikacjach dotyczących jego stosowania),

$\rightarrow$ sposób przekazania informacji zwrotnych osobom badanym i innym zainteresowanym (np. rodzicom, zespołowi orzekającemu w poradni) lub instytucjom (np. sąd).

W tym wymiarze zastosowanie określonej metody badania, wybór narzędzia i interpretacja wyników wiążą się z odpowiedzialnością diagnosty (prawną, etyczną i zawodową). Miarą profesjonalizmu w postępowaniu diagnostycznym jest utrzymywanie wysokich standardów oraz korzystanie z wiedzy i umiejętności w zgodzie $z$ wartościami zawodu (Stemplewska-Żakowicz 2008, s. 223). 



\title{
2.4.2. Wsparcie - instrumenty, zobowiązania systemowe, formalne i nieformalne formy
}

\author{
Elżbieta Neroj
}

System oświaty zapewnia realizację prawa każdego obywatela Rzeczypospolitej Polskiej do kształcenia się oraz prawa dzieci i młodzieży do wychowania i opieki, odpowiednio do wieku i osiągniętego rozwoju. Istnieją również regulacje prawne dotyczące dostosowania treści, metod i organizacji nauczania do możliwości psychofizycznych uczniów, a także związane z możliwością korzystania z pomocy psychologiczno-pedagogicznej i specjalnych form pracy dydaktycznej ${ }^{1}$. Wśród podstawowych zadań systemu oświaty ustawodawca określił zapewnianie warunków rozwoju zainteresowań i uzdolnień uczniów oraz opiekę nad uczniami niepełnosprawnymi, szczególnie uzdolnionymi oraz pozostającymi w trudnej sytuacji materialnej i życiowej.

Założenia te są realizowane poprzez określenie w przepisach prawa zróżnicowanych instrumentów wsparcia. Przez pojęcie „instrumenty wsparcia" rozumie się w niniejszym podrozdziale wszelkie zasoby, działania i strategie, których zastosowanie ma wspierać rozwój uczniów, pomagać im w nabywaniu wiedzy i umiejętności określonych w podstawach programowych, stwarzać warunki rozwijania zainteresowań oraz aktywnego i pełnego uczestnictwa w środowisku społecznym (Schalock i in. 2010, s. 18). Dla ułatwienia odbioru w tekście stosuje się określenie "uczeń", które obejmuje również dzieci w wieku przedszkolnym, jeśli opisywany instrument wsparcia stosowany jest na tym etapie edukacyjnym. 
Różne możliwości wsparcia uregulowane zostały w wielu dokumentach prawnych, zarówno na poziomie ustawowym², jak i w aktach wykonawczych - nie tylko tych, które wprost odnoszą się do obszaru kształcenia uczniów ze specjalnymi potrzebami edukacyjnymi. Wymaga to od dyrektorów jednostek systemu oświaty, nauczycieli i specjalistów planujących i realizujących działania wspierające dobrej znajomości przepisów i umiejętnego wykorzystywania wskazanych w nich możliwości w celu określenia takiego planu działań, który odpowiada potrzebom konkretnego ucznia. Rozproszenie unormowań dotyczących instrumentów wsparcia, nierzadko niespójność terminologii z przepisami regulującymi udzielanie wsparcia $w$ innych resortach ${ }^{3}$ oraz brak doprecyzowania niektórych pojęć ${ }^{4}$ - te czynniki utrudniają stosowanie prawa. Uproszczenie, uspójnienie i doprecyzowanie przepisów przyczyniłoby się do poprawy sytuacji, szczególnie rodziców, dla których znajomość regulacji prawnych i wynikających z nich możliwości w zakresie wsparcia ich dziecka jest bardzo ważna. Dzięki temu mogą oni aktywnie i świadomie włączać się w planowanie wsparcia i egzekwować realizację zadań przez przedszkole, szkołę czy placówkę. We wprowadzanych w ostatnich latach zmianach przepisów regulujących kształcenie uczniów ze specjalnymi potrzebami edukacyjnymi szczególnie podkreśla się rolę rodziców jako partnerów i współuczestników procesu oceny potrzeb rozwojowych i edukacyjnych ucznia, planowania zakresu i form wsparcia, monitorowania postępów oraz oceny efektywności udzielanego wsparcia. Rodzic ${ }^{5}$ może zainicjować udzielanie pomocy psychologiczno-pedagogicznej ${ }^{6}$. (Dz.U. z 2018 r. poz. 1457 z późn. zm.).

Przykładem są różnice w określaniu niepełnosprawności w resorcie oświaty oraz w systemie zabezpieczenia społecznego.

Na przykład pojęć: „uczeń słabosłyszący”, „słabowidzący” lub „zagrożony niedostosowaniem społecznym".

5 Pojęcie „rodzice” obejmuje również prawnych opiekunów dziecka oraz osoby (podmioty) sprawujące nad nim pieczę zastępczą.

Par. 5 pkt 2 Rozporządzenia Ministra Edukacji Narodowej z dnia 9 sierpnia 2017 r. w sprawie zasad organizacji i udzielania pomocy psychologiczno-pedagogicznej w publicznych przedszkolach, szkołach i placówkach (Dz.U. poz. 1591 z późn. zm.); par. 6 pkt 2 Rozporządzenia Ministra Edukacji Narodowej z dnia 30 kwietnia 2013 r. w sprawie zasad udzielania i organizacji pomocy psychologiczno-pedagogicznej w publicznych szkołach i placówkach (Dz.U. poz. 532 z późn. zm.). 
Ma także prawo uczestniczyć w opracowaniu i modyfikacji indywidualnego programu edukacyjno-terapeutycznego dla swojego dziecka oraz brać udział w wielospecjalistycznej ocenie jego funkcjonowania7. To rodzic lub pełnoletni uczeń zgłaszają się do poradni psychologiczno-pedagogicznej i wnioskują o wydanie opinii ${ }^{2}$ lub orzeczenia ${ }^{9}$. Również do nich należy decyzja o formie kształcenia specjalnego ${ }^{10}$, którą zobowiązany jest zapewnić organ samorządu terytorialnego odpowiedzialny za prowadzenie danego rodzaju szkoły lub placówki.

W dalszej części zostanie wskazana rola rodziców i ich prawa w odniesieniu do poszczególnych instrumentów wsparcia, aby zachęcić ich do wykorzystania istniejących możliwości współpracy z przedszkolem czy szkołą. Jak pokazują badania, znaczny odsetek rodziców nie bierze udziału w kształceniu własnych dzieci (Kubicki i in. 2015, s. 120). Włączenie ich w ten proces pozwoli możliwie najlepiej wykorzystać czas edukacji do przygotowania dzieci do samodzielnego, satysfakcjonującego życia w dorosłości. Nauczyciele i dyrektorzy szkół zobowiązani są do zapewnienia rodzicom realnych warunków realizacji ich praw. Nie tylko obowiązek powinien być jednak powodem podejmowania takich działań. Dobrze zorganizowana współpraca z rodzicami przekłada się pozytywnie na rozwój dziecka, warunki i efekty pracy nauczycieli i dyrektora szkoły oraz klimat placówki edukacyjnej. Relacje między nauczycielami i rodzicami mogą być czynnikiem wpływającym na jakość nauczania, budowanie jednolitej strategii edukacyjnej w szkole i w rodzinie, kształtowanie postaw obywatelskich (Hernik, Malinowska 2015, s. 8). Nadal jednak istnieją bariery, które utrudniają

Par. 6 ust. 11 Rozporządzenia Ministra Edukacji Narodowej z dnia 9 sierpnia 2017 r. w sprawie warunków organizowania kształcenia, wychowania i opieki dla dzieci i młodzieży niepełnosprawnych, niedostosowanych społecznie i zagrożonych niedostosowaniem społecznym (Dz.U. poz. 1578 z późn. zm.); par. 6 ust. 10 Rozporządzenia Ministra Edukacji Narodowej z dnia 24 lipca 2015 r. w sprawie warunków organizowania kształcenia, wychowania i opieki dla dzieci i młodzieży niepełnosprawnych, niedostosowanych społecznie i zagrożonych niedostosowaniem społecznym (Dz.U. poz. 1113 z późn. zm.).

Par. 5 ust. 1 Rozporządzenia Ministra Edukacji Narodowej z dnia 1 lutego 2013 r. w sprawie szczegółowych zasad działania publicznych poradni psychologiczno-pedagogicznych (Dz.U. poz. 199 oraz z 2017 r. poz. 1647).

Par. 5 ust. 2 Rozporządzenia Ministra Edukacji Narodowej z dnia 7 września 2017 r. w sprawie wydawania orzeczeń i opinii działających w publicznych poradniach psychologiczno-pedagogicznych (Dz.U. poz. 1743). 
prowadzenie tej współpracy w praktyce (Lewicka-Zelent, Chimicz 2018, s. 98-100).

Przepisy prawne zobowiązują publiczną szkołę podstawową do przyjęcia każdego dziecka zamieszkałego w jej obwodzie ${ }^{11}$. Zarówno szkoła obwodowa, jak i ta, do której uczeń został przyjęty w toku rekrutacji, nie może odmówić przyjęcia kandydata posiadającego orzeczenie o potrzebie kształcenia specjalnego, argumentując, że nie posiada warunków czy możliwości zapewnienia mu wsparcia. Przepisy wskazują wprost, że szkoła jest zobowiązana do realizacji zaleceń zawartych w orzeczeniu ${ }^{12}$ oraz do zapewnienia uczniowi - tak jak w przypadku jego rówieśników - pomocy psychologiczno-pedagogicznej adekwatnej do jego potrzeb ${ }^{13}$. Środki na ten cel przekazywane są z budżetu państwa w części oświatowej subwencji ogólnej ${ }^{14}$.

\section{Planowanie wsparcia}

Plan oddziaływań wspierających ucznia zawsze powinien być unikalny, nie ma bowiem dwóch identycznie funkcjonujących osób. Ten sam rodzaj niepełnosprawności czy to samo rozpoznanie medyczne może przejawiać się w różny sposób i w różnym nasileniu u poszczególnych uczniów. Każde dziecko ma niepowtarzalny zasób zdolności i mocnych stron, a środowisko (szkoła, dom, grupa rówieśnicza) w różny sposób wpływa na jego rozwój i codzienne funkcjonowanie. Holistyczne postrzeganie potrzeb każdego dziecka i planowanie pracy oparte na założeniu, że każde z nich może czynić postępy, stanowi

Tamże, art. 130 ust. 2.

Zgodnie z art. 68 ust. 1 pkt 10 ww. ustawy odpowiada za to dyrektor szkoły. Zobowiązanie to dotyczy również dyrektora przedszkola, jak i placówki. Regulacje w tym zakresie zawarte są także w przepisach rozporządzeń Ministra Edukacji Narodowej w sprawie warunków organizowania kształcenia, wychowania i opieki dla dzieci i młodzieży niepełnosprawnych, niedostosowanych społecznie i zagrożonych niedostosowaniem społecznym z dnia 24 lipca 2015 r. (par. 5) oraz z dnia 9 sierpnia 2017 r. (par. 5).

Zgodnie z art. 1 pkt 5 ustawy Prawo oświatowe oraz z przepisami w sprawie zasad organizacji i udzielania pomocy psychologiczno-pedagogicznej w publicznych przedszkolach, szkołach i placówkach.

Zgodnie z art. 8 Ustawy z dnia 27 października 2017 r. o finansowaniu zadań oświatowych (Dz.U. poz. 2203 z późn. zm.) w danym roku budżetowym na realizację zadań związanych z organizacją kształcenia specjalnego oraz zajęć rewalidacyjno-wychowawczych jednostka samorządu terytorialnego przeznacza środki w wysokości nie mniejszej niż kwota przewidziana w części oświatowej subwencji ogólnej na ten cel. 
realizację w praktyce idei indywidualizacji ${ }^{15}$. Jest ona obecnie coraz częściej określana jako „personalizacja” procesu uczenia się, co sprzyja podkreśleniu jego osobistego charakteru w rozwoju ucznia, będącego jednocześnie podmiotem oddziaływań, jak i ich współkreatorem. Często niesłusznie indywidualizacja utożsamiana jest z postrzeganiem indywidualnych oddziaływań wobec dziecka jako bardziej skutecznych od uczenia się w grupie i dlatego najlepiej wspierających jego rozwój. Tymczasem nie tylko rozwijanie kompetencji społeczno-emocjonalnych dziecka nie może odbywać się w oderwaniu od grupy rówieśniczej - uczenie się w grupie zróżnicowanej pod względem możliwości i potrzeb edukacyjnych sprzyja osiągnięciom akademickim i wspiera rozwój społeczny wszystkich uczniów, nie tylko tych, u których rozpoznano specjalne potrzeby edukacyjne (INCLUD-ED 2012, [za: Europejska Agencja 2016, s. 59]).

Im wyższy poziom edukacyjny, na którym oferuje się instrument wsparcia, tym większą liczbę podmiotów obejmuje jego oddziaływanie. Wprowadzenie udogodnień, które służą uczniowi ze specjalnymi potrzebami edukacyjnymi, może także poprawić warunki uczenia się jego kolegów. Dlatego w przypadku wystąpienia trudności u danego ucznia konieczne jest rozważenie, czy bariera, która utrudnia jego funkcjonowanie, nie występuje na poziomie szkoły lub klasy, a w związku z tym, czy jej usunięcie nie poprawi warunków uczenia się również jego kolegów i koleżanek.

Uczeń jest zanurzony w swoistym ekosystemie struktur i procesów zachodzących na różnych poziomach, które mają wpływ na jego rozwój, naukę i osiągnięcia (Europejska Agencja 2017a, s. 11). Mimo że podmiotem oddziaływań zawsze będzie uczeń, a ich celem będzie zapewnienie mu optymalnych warunków rozwoju i nauki, niezbędne są także działania skierowane do środowiska wychowania i nauczania (przedszkola, szkoły, klasy, grupy rówieśniczej, rodziny, do społeczności lokalnej), a także na poziomie krajowym, na którym zapewniane są ramy organizacyjne i standardy działania oraz - co równie ważne - budowany jest klimat społeczny sprzyjający edukacji włączającej. Takie pojmowanie wsparcia w procesie kształcenia i wychowania opiera się na zrozumieniu, że specjalne potrzeby edukacyjne powstają w wyniku rozbieżności 
między osobistymi kompetencjami ucznia a wymaganiami środowiska edukacyjnego i wychowawczego, w jakim funkcjonuje (Schalock i in. 2012 [za: Hagiwara i in. 2019, s. 4]). Zastosowanie instrumentów wsparcia służy niwelowaniu tych rozbieżności poprzez zapewnienie uczniom jak najszerszego dostępu do treści nauczania i umożliwienie czynienia postępów na miarę ich możliwości. Dzieci z bardziej złożonymi potrzebami, wymagające intensywniejszego wsparcia, mogą również efektywnie uczyć się zgodnie z podstawą programową realizowaną w szkole ogólnodostępnej, gdy zapewni się im odpowiednią pomoc dydaktyczną ${ }^{16}$, działania wspomagające uczestnictwo oraz dostosowania programowe (Hagiwara i in. 2019, s. 5).

W przepisach prawa oświatowego przewidziano instrumenty wsparcia na różnych poziomach oddziaływań - społeczności lokalnej, przedszkola, szkoły lub placówki, klasy, grupy wychowawczej, nauczycieli i specjalistów, rodziców, a także skierowane bezpośrednio do dziecka lub ucznia ${ }^{17}$.

Rysunek 1. Poziomy stosowania instrumentów wsparcia

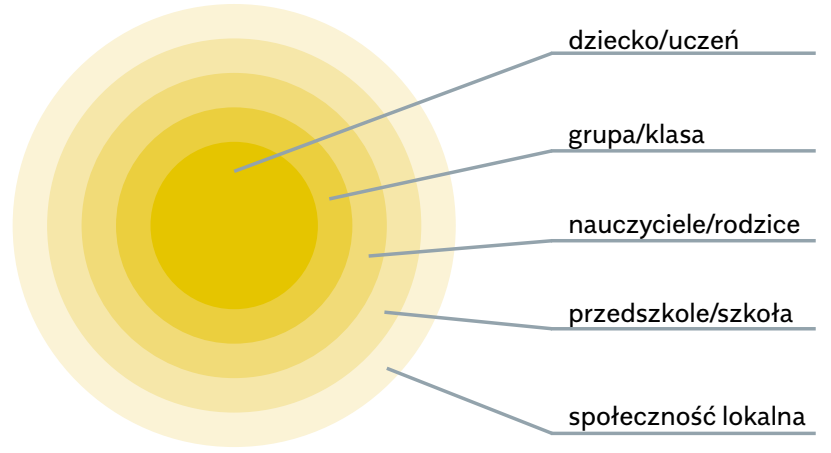

Źródło: Opracowanie własne.

$16 \quad$ Na przykład przez dostosowanie do potrzeb ucznia formy i sposobu przekazu wyjaśnień i poleceń, zastosowanie technologii wspomagających, odpowiedni dobór materiałów dydaktycznych.

17 Tekst odzwierciedla stan prawny obowiązujący 30 lipca 2019 r. 
Zaplanowanie rodzaju instrumentów wsparcia, jakie należałoby zastosować do rozwiązania konkretnego problemu dotyczącego funkcjonowania ucznia, musi być poprzedzone określeniem celów, które mają zostać osiągnięte (Petty 2013, s. 381-392), jak również wskaźników, które pozwolą ocenić postępy tego procesu. Jeśli cele oddziaływań będą jasno zdefiniowane (precyzyjne), mierzalne, osiągalne, istotne dla poprawy funkcjonowania dziecka oraz określone w czasie (czyli zaprojektowane zgodnie z zasadą SMART ${ }^{18}$ ) - łatwiej je będzie osiągnąć.

Każdy uczeń może czynić postępy i rozwijać się. W sytuacji, gdy napotyka na trudności w rozwoju czy nauce, rolą nauczyciela jest zastosowanie odpowiednich metod pracy, które pomogą w ich przezwyciężeniu. Nie może on być $w$ tym zadaniu osamotniony - powinien współpracować $z$ innymi nauczycielami, specjalistami ( $w$ tym także spoza przedszkola/szkoły), rodzicami i samymi uczniami. Możliwości w tym zakresie są określone w przepisach, występuje jednak często problem z ich stosowaniem w praktyce. Urzeczywistnianiu tej współpracy sprzyja rozwijanie kompetencji przywódczych dyrektorów szkół i komunikacyjnych nauczycieli, jak również ograniczanie biurokracji (Chmielińska, Modrzejewska-Świgulska 2018, s. 12-13).

Jednym z ważnych obszarów pracy przedszkola i szkoły jest efektywne korzystanie ze zgromadzonych przez placówkę i dostępnych w środowisku lokalnym zasobów w taki sposób, by skutecznie wspierać wszystkie dzieci w rozwoju oraz nabywaniu wiedzy i umiejętności na możliwie najwyższym poziomie, a także wzmacniać ich autentyczne zaangażowanie $w$ proces uczenia się.

Aby powyższe założenia mogły być realizowane w codziennej praktyce, konieczne jest wzmacnianie potencjału przedszkoli i szkół w: zapewnianiu wsparcia jak najszybciej po rozpoznaniu takiej potrzeby, stosowaniu innowacyjnych metod nauczania w odpowiedzi na zróżnicowane potrzeby uczniów, jak również umożliwianiu realizacji spersonalizowanych ścieżek kształcenia przez uczniów (Europejska Agencja 2019, s. 9). 


\section{Instrumenty wsparcia przeznaczone dla przedszkola, szkoły i placówki jako instytucji oraz kadry}

W realizacji zadań dydaktycznych, wychowawczych i opiekuńczych przedszkola, szkoły i placówki mogą korzystać ze wsparcia publicznych poradni psychologiczno-pedagogicznych, placówek doskonalenia nauczycieli oraz bibliotek pedagogicznych. O tego rodzaju pomoc zwraca się przede wszystkim zainteresowana placówka, ale wsparcie może zostać uruchomione również w efekcie procesu diagnozy dziecka lub ucznia w poradni psychologiczno-pedagogicznej 19 lub na wniosek rodzica dziecka niepełnosprawnego bądź pełnoletniego ucznia ${ }^{20}$.

Publiczna poradnia psychologiczno-pedagogiczna na terenie określonym przez jej organ prowadzący oferuje pomoc dzieciom od ich urodzenia, uczniom, ich rodzicom i nauczycielom, a także wspomaga przedszkola, szkoły i placówki jako organizacje. Zakres działań poradni jest szeroki i obejmuje zwłaszcza:

$\rightarrow$ wsparcie merytoryczne i pomoc dla nauczycieli, opiekunów grup wychowawczych i specjalistów w rozpoznawaniu potrzeb i możliwości psychofizycznych dzieci (uczniów) oraz planowaniu i realizacji określonych zadań (m.in. w zakresie doradztwa edukacyjno-zawodowego, pomocy psychologiczno-pedagogicznej, rozwijania zainteresowań i uzdolnień uczniów);

$\rightarrow$ współpracę w opracowywaniu i realizowaniu indywidualnych programów dla uczniów (edukacyjno-terapeutycznych oraz rewalidacyjno-wychowawczych);

$\rightarrow$ współpracę w określeniu niezbędnych do nauki dzieci i uczniów niepełnosprawnych warunków, sprzętu specjalistycznego i środków dydaktycznych, w tym wykorzystujących technologie informacyjno-komunikacyjne (taką współpracą może także zainicjować rodzic lub pełnoletni uczeń) ${ }^{21}$;

$\rightarrow$ organizowanie i prowadzenie tzw. kompleksowego wspomagania przedszkoli, szkół i placówek w zakresie realizacji zadań dydaktycznych, wychowawczych i opiekuńczych. poradni psychologiczno-pedagogicznych. 
Przepisy umożliwiają dostosowanie oferty poradni do lokalnych potrzeb. Formy wsparcia oferowane przez te placówki to: porady, konsultacje, udział w spotkaniach nauczycieli, opiekunów grup wychowawczych i specjalistów oraz w zebraniach rad pedagogicznych, warsztaty, grupy wsparcia, wykłady, prelekcje, mediacje, interwencje kryzysowe, działania informacyjno-szkoleniowe, a także organizowanie i prowadzenie sieci współpracy i samokształcenia.

Wspomaganie w realizacji zadań dydaktycznych, wychowawczych i opiekuńczych polega na zaplanowaniu i przeprowadzeniu działań mających na celu poprawę jakości pracy przedszkola, szkoły lub placówki. Odbywa się ono w zakresie, który wynika z rozpoznania potrzeb dzieci i młodzieży oraz z indywidualizacji procesu nauczania i wychowania, analizy wyników i wniosków z nadzoru pedagogicznego oraz wyników egzaminów zewnętrznych, a także z innych potrzeb wskazanych przez przedszkole, szkołę lub placówkę. Obejmuje pomoc w diagnozowaniu problemów, ustalenie sposobów działania prowadzących do ich zniwelowania, zaplanowanie form wspomagania i ich realizację, a także wspólną ocenę efektów i opracowanie wniosków po zakończeniu procesu wspomagania. Jest to jedno z obowiązkowych zadań nie tylko publicznych poradni psychologiczno-pedagogicznych, ale również publicznych placówek doskonalenia nauczycieli oraz bibliotek pedagogicznych.

Obok realizowania różnych form doskonalenia zawodowego nauczycieli oraz dyrektorów przedszkoli, szkół i placówek systemu oświaty, publiczne placówki doskonalenia nauczycieli organizują i prowadzą sieci współpracy i samokształcenia dla nauczycieli oraz dyrektorów, udzielają konsultacji i upowszechniają przykłady dobrej praktyki ${ }^{22}$.

Publiczne biblioteki pedagogiczne wspierają proces kształcenia i doskonalenia nauczycieli oraz działalność szkół i placówek poprzez zapewnianie dostępu do zasobów informacyjnych (m.in. dotyczących problematyki związanej z udzielaniem dzieciom i młodzieży oraz rodzicom i nauczycielom pomocy psychologiczno-pedagogicznej), prowadzenie działalności informacyjnej i bibliograficznej oraz inspirowanie, a także promowanie edukacji czytelniczej i medialnej23. Biblioteki mogą doskonalenia nauczycieli (Dz.U. poz. 1045). 
również prowadzić działalność wydawniczą, edukacyjną i kulturalną, (np. w ramach otwartych zajęć edukacyjnych, lekcji bibliotecznych i spotkań autorskich).

Wsparcie szkół w diagnozowaniu i rozwiązywaniu problemów dydaktyczno-wychowawczych uczniów objętych kształceniem specjalnym zapewniają również placówki specjalne: młodzieżowe ośrodki wychowawcze, młodzieżowe ośrodki socjoterapii oraz specjalne ośrodki szkolno-wychowawcze ${ }^{24}$.

Szkoła nie powinna biernie oczekiwać na zainteresowanie zewnętrznych podmiotów jej problemami (co najczęściej występuje w sytuacji pojawienia się poważnych problemów z funkcjonowaniem uczniów), a raczej aktywnie poszukiwać sojuszników do realizacji swoich zadań (Ainscow i in. 2012, cytowane w: Europejska Agencja 2016b). Proces rozwoju szkoły jako organizacji uczącej się obejmuje ciągłe doskonalenie metod własnej pracy w odpowiedzi na potrzeby uczniów. Celem powinno być rozszerzanie oferty działań profilaktycznych i prewencyjnych, zamiast koncentrowania się przede wszystkim na interwencji w sytuacji wystąpienia problemów oraz kompensowaniu deficytów (Europejska Agencja 2019, s. 6).

Społeczność lokalna stanowi ogromny zasób dla placówek edukacyjnych. Możliwości uzyskania nieformalnego wsparcia ze strony różnych podmiotów działających lokalnie są praktycznie nieograniczone. Jak pokazuje praktyka, najczęściej jest to wsparcie zapewniane przez rodziców, lokalnych przedsiębiorców oraz służby publiczne, w tym policję i straż pożarną, jak również organizacje pozarządowe działające na rzecz dzieci i młodzieży oraz rodziny. W wielu miejscach w Polsce z sukcesami działają inicjowane przez samorządy koalicje, które wspierają nie tylko rozwój edukacji włączającej, ale także służą budowaniu dostępnego, włączającego środowiska lokalnego ${ }^{25}$. wychowawczych, młodzieżowych ośrodków socjoterapii, specjalnych ośrodków szkolno-wychowawczych, specjalnych ośrodków wychowawczych, ośrodków rewalidacyjno-wychowawczych oraz placówek zapewniających opiekę i wychowanie uczniom w okresie pobierania nauki poza miejscem stałego zamieszkania (Dz.U. poz. 1606 oraz z 2017 r. poz. 1628). 


\section{Instrumenty wsparcia związane z organizacją przedszkola, szkoły lub placówki}

Potrzeby rozwojowe i edukacyjne oraz możliwości psychofizyczne wszystkich uczniów powinny być uwzględnione na etapie planowania pracy $w$ danym roku szkolnym. Należy zadbać o:

1. Zaplanowanie w arkuszu organizacji przedszkola, szkoły, placówki26 odpowiednio do rozpoznanych potrzeb edukacyjnych i rozwojowych dzieci i uczniów:

- kadry przygotowanej do ich zaspokojenia: nauczycieli, wychowawców, specjalistów oraz personelu niepedagogicznego ${ }^{27}$,

- liczby godzin zajęć rewalidacyjnych (dla uczniów niepełnosprawnych, posiadających orzeczenie o potrzebie kształcenia specjalnego) ${ }^{28}$, resocjalizacyjnych (dla uczniów niedostosowa-

Par. 17 Rozporządzenia Ministra Edukacji Narodowej z dnia 17 marca 2017 r. w sprawie szczegółowej organizacji publicznych szkół i publicznych przedszkoli (Dz.U. poz. 649 oraz z 2018 r. poz. 691); par. 73 rozporządzenia w sprawie publicznych placówek oświatowo-wychowawczych, młodzieżowych ośrodków wychowawczych, młodzieżowych ośrodków socjoterapii, specjalnych ośrodków szkolno-wychowawczych, specjalnych ośrodków wychowawczych, ośrodków rewalidacyjno-wychowawczych oraz placówek zapewniających opiekę i wychowanie uczniom w okresie pobierania nauki poza miejscem stałego zamieszkania.

Wynika to z obowiązku zapewnienia pomocy psychologiczno-pedagogicznej zgodnie z art. 1 pkt 5 ustawy Prawo oświatowe, par. 1 i 4 ust. 1 i 2 rozporządzenia Ministra Edukacji Narodowej z dnia 9 sierpnia 2017 r. w sprawie zasad organizacji i udzielania pomocy psychologiczno-pedagogicznej w publicznych przedszkolach, szkołach i placówkach, par. 1 i 5 ust. 2 oraz rozporządzeń Ministra Edukacji Narodowej w sprawie warunków organizowania kształcenia, wychowania i opieki dla dzieci i młodzieży niepełnosprawnych, niedostosowanych społecznie i zagrożonych niedostosowaniem społecznym: z dnia 9 sierpnia 2017 r. (par. 7) oraz z dnia 24 lipca 2015 r. (par. 7).

Rozporządzenia Ministra Edukacji Narodowej w sprawie warunków organizowania kształcenia, wychowania i opieki dla dzieci i młodzieży niepełnosprawnych, niedostosowanych społecznie i zagrożonych niedostosowaniem społecznym: z dnia 9 sierpnia 2017 r. (par. 6 ust. 1 pkt 5) oraz z dnia 24 lipca 2015 r. (par. 6 ust. 1 pkt 5). Minimalna tygodniowa liczba takich zajęć jest określona w przepisach w sprawie ramowych planów nauczania odpowiednio na ucznia (szkoły/ oddziały ogólnodostępne i integracyjne) oraz na oddział (szkoły specjalne, oddziały specjalne w szkołach ogólnodostępnych). Rzeczywista liczba godzin zajęć oraz ich forma (indywidualna lub grupowa) powinny zawsze wynikać z potrzeb poszczególnych uczniów. Dotyczy to także szkół i oddziałów specjalnych: uczeń realizuje taką liczbę i taki rodzaj zajęć rewalidacyjnych, jakie wynikają z jego indywidualnego programu edukacjo-terapeutycznego. Brak określenia w przepisach minimalnej liczby godzin zajęć rewalidacyjnych w przedszkolu nie oznacza, że nie ma obowiązku realizacji tych zajęć - przeciwnie, wymóg taki wskazano zarówno w ustawie Prawo oświatowe (art. 1 oraz art. 127 ust. 4), jak i w przepisach wydanych na podstawie art. 127 ust. 19 pkt 2 tej ustawy. 
nych społecznie) ${ }^{29}$ oraz socjoterapeutycznych (dla uczniów zagrożonych niedostosowaniem społecznym) ${ }^{30}$,

- liczby godzin zajęć z zakresu pomocy psychologiczno-pedagogicznej oraz innych, wspomagających proces kształcenia, realizowanych w szczególności przez pedagoga, psychologa, logopedę i innych nauczycieli;

2. Ustalenie rodzaju i liczebności oddziałów (ogólnodostępnych, integracyjnych, specjalnych, klas terapeutycznych ${ }^{31}$, przygotowawczych ${ }^{32}$ );

3. Opracowanie programu wychowawczo-profilaktycznego ${ }^{33}$;

4. Zaplanowanie działań w zakresie doskonalenia nauczycieli34;

5. Opracowanie planu nadzoru pedagogicznego ${ }^{35}$;

6. Zaplanowanie działań w zakresie doradztwa zawodowego ${ }^{36}$.

29 Rozporządzenia Ministra Edukacji Narodowej w sprawie warunków organizowania kształcenia, wychowania i opieki dla dzieci i młodzieży niepełnosprawnych, niedostosowanych społecznie i zagrożonych niedostosowaniem społecznym: z dnia 9 sierpnia 2017 r. (par. 6 ust. 1 pkt 5) oraz z dnia 24 lipca 2015 r. (par. 6 ust. 1 pkt 5).

Tamże.

Par. 13 rozporządzenia Ministra Edukacji Narodowej z dnia 9 sierpnia 2017 r. w sprawie zasad organizacji i udzielania pomocy psychologiczno-pedagogicznej w publicznych przedszkolach, szkołach i placówkach; par. 8 rozporządzenia Ministra Edukacji Narodowej z dnia 30 kwietnia 2013 r. w sprawie zasad udzielania i organizacji pomocy psychologiczno-pedagogicznej w publicznych szkołach i placówkach.

Art. 165 ust. 11-13 ustawy Prawo oświatowe oraz par. 16 Rozporządzenia Ministra Edukacji Narodowej z dnia 23 sierpnia 2017 r. w sprawie kształcenia osób niebędących obywatelami polskimi oraz osób będących obywatelami polskimi, które pobierały naukę w szkołach funkcjonujących w systemach oświaty innych państw (Dz.U. poz. 1655).

Zgodnie z art. 26 ustawy Prawo oświatowe. Pomocne materiały do realizacji tych zadań znajdują się na stronie programu „Bezpieczna szkoła” (bezpiecznaszkola.men.gov.pl).

Art. 7 ust. 2 pkt 4 Ustawy z dnia 26 stycznia 1982 r. Karta Nauczyciela (Dz.U. z 2018 r. poz. 967 z późn. zm.) oraz par. 4 Rozporządzenia Ministra Edukacji Narodowej z dnia 18 stycznia 2019 r. w sprawie dofinansowania doskonalenia zawodowego nauczycieli (Dz.U. poz. 136). nadzoru pedagogicznego (Dz.U. poz. 1658). Narodowej z dnia 16 sierpnia 2018 r. w sprawie doradztwa zawodowego (Dz.U. poz. 1675). 


\section{Instrumenty wsparcia skierowane}

\section{do klasy lub do grupy wychowawczej}

Wśród instrumentów wsparcia skierowanych do oddziału przedszkolnego lub klasowego można wyróżnić:

1. Możliwość dostosowania liczebności grupy wychowawczej lub klasy ${ }^{37}$;

2. Ustalenie tygodniowego rozkładu zajęć (w tym godziny ich rozpoczęcia i zakończenia w poszczególnych dniach, z uwzględnieniem specyficznych potrzeb uczniów, wynikających np. z przewlekłej choroby);

3. Zapewnienie dodatkowej kadry, zwłaszcza w przypadku, gdy do oddziału uczęszczają uczniowie objęci kształceniem specjalnym, a także określenie zakresu czynności poszczególnych pracowników ${ }^{38}$. Mogą to być: nauczyciele posiadający kwalifikacje w zakresie pedagogiki specjalnej ${ }^{39}$, specjaliści, pomoc nauczyciela;

4. Okresowe lub roczne zwiększenie liczby godzin wybranych obowiązkowych zajęć edukacyjnych ${ }^{40}$;

5. Realizację dodatkowych zajęć edukacyjnych ${ }^{41}$;

6. Prowadzenie zajęć z języka migowego ${ }^{42}$;

Z uwzględnieniem przepisów rozporządzenia w sprawie szczegółowej organizacji publicznych szkół i publicznych przedszkoli. Należy zauważyć, że określają one górną, a nie dolną granicę liczebności oddziałów.

Zgodnie z przepisami rozporządzeń Ministra Edukacji Narodowej w sprawie warunków organizowania kształcenia, wychowania i opieki dla dzieci i młodzieży niepełnosprawnych, niedostosowanych społecznie i zagrożonych niedostosowaniem społecznym: $z$ dnia 9 sierpnia 2017 r. (par. 7) oraz z dnia 24 lipca 2015 r. (par. 7).

Obowiązkowo w przypadku oddziału integracyjnego, opcjonalnie - oddziału ogólnodostępnego.

Na podstawie par. 3 ust. 1 pkt 1 Rozporządzenia Ministra Edukacji Narodowej z dnia 28 marca 2017 r. w sprawie ramowych planów nauczania dla publicznych szkół (Dz.U. poz. 703).

Na podstawie par. 3 ust. 1 pkt 2 ww. rozporządzenia. Do dodatkowych zajęć edukacyjnych zalicza się: te z języka obcego nowożytnego innego niż nauczany w ramach obowiązkowych zajęć edukacyjnych oraz zajęcia, dla których nie została ustalona podstawa programowa, lecz program nauczania tych zajęć został włączony do szkolnego zestawu programów nauczania (art. 109 ust 1 pkt 2 ustawy Prawo oświatowe).

42 Na podstawie par. 3 ust. 1 pkt 3 rozporządzenia w sprawie ramowych planów nauczania dla publicznych szkół. 
7. Naukę geografii państwa, z którego obszarem kulturowym utożsamia się mniejszość narodowa ${ }^{43}$;

8. Odpowiednie do potrzeb uczniów wyposażenie klasy (np. zapewnienie ławki dostosowanej do ucznia poruszającego się na wózku inwalidzkim, kącik do wypoczynku), sprzęt specjalistyczny (np. pętla indukcyjna, linijka brajlowska lub komputer z oprogramowaniem dla osób niewidomych), pomoce dydaktyczne $^{44}$ (np. tablica interaktywna, materiały w języku Braille'a lub polskim języku migowym);

9. Dostosowanie organizacji pracy w grupie/na lekcji (np. aranżacja klasy - ustawienie ławek, krzeseł);

10. Dobór odpowiednich metod pracy.

\section{Instrumenty wsparcia kierowane do rodziców uczniów}

Przedszkola, szkoły i placówki zobowiązane są do zapewniania pomocy psychologiczno-pedagogicznej rodzicom. Pomoc ta polega na wspieraniu ich w rozwiązywaniu problemów wychowawczych i dydaktycznych oraz rozwijaniu umiejętności wychowawczych rodziców ${ }^{45}$. Rodzice mogą skorzystać również z usług poradni psychologiczno-pedagogicznych (publicznych i niepublicznych). Poradnie publiczne oferują pomoc w rozpoznawaniu potrzeb dzieci i młodzieży oraz w rozwiązywaniu problemów edukacyjnych i wychowawczych, wsparcie terapeutyczne (np. terapię rodziny), interwencję kryzysową, mediację. Organizują także grupy wsparcia, warsztaty, prelekcje, udzielają porad i konsultacji. Usługi publicznych poradni są nieodpłatne, a wsparcie odbywa się zawsze na wniosek rodzica.

43 Na podstawie par. 3 ust. 1 pkt 4 ww. rozporządzenia. Zgodnie z art. 2 ust. 2 Ustawy z dnia 6 stycznia 2005 r. o mniejszościach narodowych i etnicznych oraz o języku regionalnym (Dz.U. z 2017 r. poz. 823) w Polsce status mniejszości posiadają osoby narodowości: białoruskiej, czeskiej, litewskiej, niemieckiej, ormiańskiej, rosyjskiej, słowackiej, ukraińskiej, żydowskiej.

44 Zgodnie z art. 10 ustawy Prawo oświatowe oraz rozporządzeń Ministra Edukacji Narodowej w sprawie warunków organizowania kształcenia, wychowania i opieki dla dzieci i młodzieży niepełnosprawnych, niedostosowanych społecznie i zagrożonych niedostosowaniem społecznym: z dnia 9 sierpnia 2017 r. (par. 5 pkt 2) oraz z dnia 24 lipca 2015 r. (par. 5 pkt 2).

Rozporządzenia Ministra Edukacji Narodowej: z dnia 9 sierpnia 2017 r. w sprawie w sprawie zasad organizacji i udzielania pomocy psychologiczno-pedagogicznej w publicznych przedszkolach, szkołach i placówkach oraz z dnia 30 kwietnia 2013 r. w sprawie zasad udzielania i organizacji pomocy psychologiczno-pedagogicznej w publicznych szkołach i placówkach. 


\section{Instrumenty wsparcia skierowane do dziecka/ucznia}

Przepisy określają wiele instrumentów skierowanych bezpośrednio do dziecka/ucznia ${ }^{46}$. Wśród nich można wyróżnić:

1. Wczesne wspomaganie rozwoju dziecka ${ }^{47}$;

2. Dostosowanie czasu realizacji wychowania przedszkolnego, rozpoczęcia realizacji obowiązku szkolnego oraz okresu kształcenia na poszczególnych etapach edukacyjnych ${ }^{48}$;

3. Dostosowanie treści programowych ${ }^{49}$, programów nauczania 50 oraz wymagań edukacyjnych do indywidualnych potrzeb rozwojowych i edukacyjnych oraz możliwości psychofizycznych uczniów ${ }^{51}$;

Zdecydowanie więcej jest instrumentów wsparcia skierowanych do dziecka/ucznia niż do innych podmiotów i poziomów oddziaływań. W celu podnoszenia jakości kształcenia i zwiększania uczestnictwa wszystkich uczniów w edukacji włączającej należałoby rozważyć poszerzenie możliwości wsparcia całej klasy z uczniami o różnorodnych potrzebach edukacyjnych oraz nauczyciela, który prowadzi w niej zajęcia.

47 Na podstawie art. 127 ust. 5-9 ustawy Prawo oświatowe oraz Rozporządzenia Ministra Edukacji Narodowej z dnia 24 sierpnia 2017 r. w sprawie organizowania wczesnego wspomagania rozwoju dzieci (Dz.U. poz. 1635).

Art. 31 ust. 2 i 3 oraz art. 36 ust. 1-8 ustawy Prawo oświatowe oraz par. 5-6 Rozporządzenia Ministra Edukacji Narodowej z dnia 28 marca 2017 r. w sprawie ramowych planów nauczania dla publicznych szkół (Dz.U. poz. 703).

49 Obejmuje wybór podstawy programowej kształcenia ogólnego.

50 Art. 22a ust. 5 ustawy o systemie oświaty, par. 1 Rozporządzenia Ministra Edukacji Narodowej z dnia 9 sierpnia 2017 r. w sprawie warunków i trybu udzielania zezwoleń na indywidualny program lub tok nauki oraz organizacji indywidualnego programu lub toku nauki (Dz.U. poz. 1569).

Art. 1 pkt 5 ustawy Prawo oświatowe, art. 44c ust. 2 ustawy o systemie oświaty; Rozporządzenie Ministra Edukacji Narodowej z dnia 14 lutego 2017 r. w sprawie podstawy programowej wychowania przedszkolnego oraz podstawy programowej kształcenia ogólnego dla szkoły podstawowej, w tym dla uczniów z niepełnosprawnością intelektualną w stopniu umiarkowanym lub znacznym, kształcenia ogólnego dla branżowej szkoły I stopnia, kształcenia ogólnego dla szkoły specjalnej przysposabiającej do pracy oraz kształcenia ogólnego dla szkoły policealnej (Dz.U. poz. 356 oraz z 2018 r. poz. 1679); par. 2 Rozporządzenia Ministra Edukacji Narodowej z dnia 3 sierpnia 2017 r. w sprawie oceniania, klasyfikowania i promowania uczniów i słuchaczy w szkołach publicznych (Dz.U. poz. 1534); par. 6 ust. 1 pkt 1 rozporządzenia Ministra Edukacji Narodowej z dnia 9 sierpnia 2017 r. w sprawie warunków organizowania kształcenia, wychowania i opieki dla dzieci i młodzieży niepełnosprawnych, niedostosowanych społecznie i zagrożonych niedostosowaniem społecznym; par. 6 ust. 1 pkt 1 rozporządzenia Ministra Edukacji Narodowej z dnia 24 lipca 2015 r. w sprawie warunków organizowania kształcenia, wychowania i opieki dla dzieci i młodzieży niepełnosprawnych, niedostosowanych społecznie i zagrożonych niedostosowaniem społecznym; par. 5 ust. 2 i par. 10 rozporządzenia w sprawie warunków i trybu udzielania zezwoleń na indywidualny program lub tok nauki oraz organizacji indywidualnego programu lub toku nauki. 
4. Dostosowanie warunków i organizacji kształcenia - np. zajęcia edukacyjne $w$ formie indywidualnej 52 lub prowadzone $w$ grupie mniejszej niż oddział klasowy ${ }^{53}$, indywidualny tok nauki ${ }^{54}$, kształcenie specjalne ${ }^{55}$, wsparcie ze strony dodatkowej kadry ${ }^{56}$, zajęcia umożliwiające uzupełnienie programu nauczania i ustalenie oceny klasyfikacyjnej z lekcji prowadzonych w ramach praktycznej nauki zawodu ${ }^{57}$;

5. Brak obowiązku przystępowania do egzaminu ósmoklasisty 58 ;

6. Zwolnienie z egzaminu ósmoklasisty lub z jego części ${ }^{59}$;

7. Zwolnienie z części egzaminu maturalnego ${ }^{60}$;

52 Zajęcia edukacyjne w formie indywidualnej mogą być organizowane na terenie jednostki systemu oświaty, do której uczeń uczęszcza na podstawie przepisów regulujących organizację pomocy psychologiczno-pedagogicznej w przedszkolach, szkołach i placówkach lub organizację kształcenia specjalnego. Indywidualne zajęcia edukacyjne w miejscu zamieszkania dziecka/ ucznia są organizowane na podstawie przepisów rozporządzeń Ministra Edukacji Narodowej: z dnia 9 sierpnia 2017 r. w sprawie indywidualnego obowiązkowego rocznego przygotowania przedszkolnego dzieci i indywidualnego nauczania dzieci i młodzieży (Dz.U. poz. 1616) oraz z dnia 28 sierpnia 2014 r. w sprawie indywidualnego nauczania dzieci i młodzieży (Dz.U. poz. 1157 oraz z 2017 r. poz. 1656).

53 Na podstawie rozporządzeń Ministra Edukacji Narodowej w sprawie warunków organizowania kształcenia, wychowania i opieki dla dzieci i młodzieży niepełnosprawnych, niedostosowanych społecznie i zagrożonych niedostosowaniem społecznym: z dnia 9 sierpnia 2017 r. (par. 6 ust. 1 pkt 8) oraz z dnia 24 lipca 2015 r. (par. 6 ust. 1 pkt 8).

54 Art. 111 ustawy Prawo oświatowe oraz rozporządzenie w sprawie warunków i trybu udzielania zezwoleń na indywidualny program lub tok nauki oraz organizacji indywidualnego programu lub toku nauki.

55 Art. 127 ust. 1 ustawy Prawo oświatowe oraz rozporządzenia Ministra Edukacji Narodowej w sprawie warunków organizowania kształcenia, wychowania i opieki dla dzieci i młodzieży niepełnosprawnych, niedostosowanych społecznie i zagrożonych niedostosowaniem społecznym z dnia 9 sierpnia 2017 r. oraz 24 lipca 2015 r.

56 O której mowa w przepisach w sprawie warunków organizowania kształcenia, wychowania i opieki dla dzieci i młodzieży niepełnosprawnych, niedostosowanych społecznie i zagrożonych niedostosowaniem społecznym.

Art. 441 ust. 5 oraz art. 44zx ustawy o systemie oświaty.

58 Zgodnie art. $44 z w$ ust. 1 ustawy o systemie oświaty uczeń posiadający orzeczenie o potrzebie kształcenia specjalnego wydane ze względu na niepełnosprawność intelektualną w stopniu umiarkowanym lub znacznym lub niepełnosprawności sprzężone, gdy jedną, z niepełnosprawności jest niepełnosprawność intelektualna w stopniu umiarkowanym lub znacznym, nie przystępuje do egzaminu ósmoklasisty. Do żadnego z egzaminów zewnętrznych nie przystępują dzieci i młodzieży z niepełnosprawnością intelektualną w stopniu głębokim. 
8. Zwolnienie z części egzaminu potwierdzającego kwalifikacje w zawodzie ${ }^{1}$;

9. Możliwość przystąpienia do egzaminu w danym zawodzie lub zawodzie o charakterze pomocniczym przewidzianym dla tego zawodu 2 ;

10. Przystąpienie do egzaminu ósmoklasisty, maturalnego lub potwierdzającego kwalifikacje w zawodzie w terminie dodatkowym ${ }^{63}$;

11. Dostosowanie warunków ${ }^{4}$ i form ${ }^{65}$ przeprowadzania egzaminu ósmoklasisty, maturalnego oraz potwierdzającego kwalifikacje w zawodzie 6 ;

12. Działania o charakterze edukacyjnym, doradczym, wspierającym rozwój lub terapeutycznym - np. zintegrowane działania nauczycieli i specjalistów, zajęcia rozwijające zainteresowania,

Taką możliwość stworzono od 1 września 2019 r. dla uczniów posiadających orzeczenie o potrzebie kształcenia specjalnego wydane z uwagi na niepełnosprawność, którzy kształcą się w zawodzie, dla którego przewidziano zawód o charakterze pomocniczym. Mogą oni dokonać wyboru i przystąpić do egzaminu zawodowego na podstawie wymagań określonych w podstawie programowej kształcenia w zawodzie szkolnictwa branżowego dla zawodu, w którym się kształcą albo w zawodzie o charakterze pomocniczym.

Tamże: art. 44zz ust. 1, art. 44zzj ust. 1, art. 44zzzga ust. 1.

$\mathrm{Na}$ przykład przedłużenie czasu, zapewnienie odpowiednio dostosowanego miejsca pracy, sprzętu specjalistycznego i środków dydaktycznych podczas egzaminu, ustalenie zasad oceniania rozwiązań zadań wykorzystywanych do przeprowadzania egzaminu, uwzględniających potrzeby edukacyjne oraz możliwości psychofizyczne ucznia/absolwenta, zapewnienie obecności i pomocy w czasie egzaminu nauczyciela wspomagającego lub specjalisty odpowiednio z zakresu danego rodzaju niepełnosprawności, niedostosowania społecznego lub zagrożenia niedostosowaniem społecznym, jeżeli jest to niezbędne do uzyskania właściwego kontaktu z uczniem lub pomocy w obsłudze sprzętu specjalistycznego i środków dydaktycznych.

Obejmuje przygotowanie odrębnych arkuszy egzaminacyjnych dostosowanych do potrzeb edukacyjnych zdających, którzy posiadają orzeczenie o potrzebie kształcenia specjalnego wydane z uwagi na niepełnosprawność.

$\mathrm{Na}$ podstawie odpowiednio art. 44zzr, art. 44zzzf oraz art. 44zzzh ustawy o systemie oświaty. Szczegółowe sposoby dostosowania w danym roku szkolnym warunków i form przeprowadzania egzaminów zewnętrznych określane są w komunikacie dyrektora Centralnej Komisji Egzaminacyjnej (CKE) wydawanym na podstawie art. 9a ust. 2 pkt 10 lit. a ustawy o systemie oświaty. W szczególnych przypadkach losowych lub zdrowotnych dyrektor szkoły, na wniosek rady pedagogicznej, może wystąpić do dyrektora okręgowej komisji egzaminacyjnej z wnioskiem o wyrażenie zgody na przystąpienie ucznia, słuchacza albo absolwenta do egzaminu ósmoklasisty i egzaminu maturalnego w warunkach dostosowanych do jego potrzeb edukacyjnych oraz możliwości psychofizycznych, nieujętych w komunikacie dyrektora CKE. 
zajęcia z zakresu pomocy psychologiczno-pedagogicznej, zajęcia doradztwa zawodowego, rewalidacyjne, socjoterapeutyczne i resocjalizacyjne.

Do wsparcia nieformalnego ucznia zalicza się np. wolontariat szkolny (Kata 2017), tutoring szkolny ${ }^{67}$ i mediacje rówieśnicze ${ }^{68}$, ale również stwarzanie sytuacji, w których uczeń może rozwijać kompetencje społeczno-emocjonalne, poznać swoje mocne strony i zademonstrować je na forum grupy (np. wycieczki szkolne, przeglądy twórczości dzieci, gry i zawody sportowe).

\section{Wczesna pomoc i wczesne wspomaganie rozwoju dzieci}

Wczesne wspomaganie rozwoju dzieci (WWR) w systemie oświaty organizuje się od chwili wykrycia niepełnosprawności do podjęcia nauki w szkole na podstawie opinii o potrzebie objęcia nim dziecka ${ }^{69}$. Wniosek o wydanie opinii składają rodzice dziecka.

Uzupełnieniem oferty wsparcia skierowanej do małych dzieci i ich rodzin jest rządowy program kompleksowego wsparcia rodzin "Za życiem" $^{\prime \prime}$, realizowany w latach 2017-2021. W jego ramach przewidziano powołanie na terenie powiatów ośrodków koordynacyjno-rehabilitacyjno-opiekuńczych (OKRO) ${ }^{71}$. To właśnie w tych instytucjach wczesną, specjalistyczną opieką mogą być obejmowane również dzieci zagrożone niepełnosprawnością oraz ich rodziny na podstawie zaświadczenia lekarskiego. OKRO zapewniają możliwość dodatkowych oddziaływań terapeutycznych i rehabilitacyjnych, zgodnie z potrzebami dzieci, a także opiekę pielęgniarską i konsultacje lekarzy specjalistów. Udzielenie pomocy przez OKRO następuje z inicjatywy rodzica.

bit.ly/2WwFNIn [dostęp: 6.06.2019].

Opinie te wydawane są przez zespoły orzekające działające w publicznych poradniach psychologiczno-pedagogicznych na podstawie art. 127 ust. 10 ustawy z dnia 14 grudnia 2016 r. Prawo oświatowe oraz Rozporządzenia Ministra Edukacji Narodowej z dnia 7 września 2017 r. w sprawie orzeczeń i opinii wydawanych przez zespoły orzekające działające w publicznych poradniach psychologiczno-pedagogicznych (Dz.U. poz. 1743). wsparcia dla rodzin "Za życiem” (M.P. poz. 1250). 


\section{Dostosowanie czasu rozpoczęcia i zakończenia kształcenia na danym etapie edukacyjnym}

Dziecko może rozpocząć realizację obowiązku szkolnego wcześniej

o jeden rok szkolny niż jego rówieśnicy, tj. w wieku sześciu lat. Jest to możliwe w sytuacji, gdy korzystało ono $z$ wychowania przedszkolnego w roku szkolnym poprzedzającym ten, w którym ma rozpocząć naukę w szkole podstawowej, bądź gdy posiada opinię poradni psychologiczno-pedagogicznej ${ }^{72}$. Decyzję w tej sprawie na wniosek rodzica podejmuje dyrektor szkoły ${ }^{73}$.

Możliwe jest również odroczenie realizacji obowiązku szkolnego o jeden rok, a w przypadku dzieci z niepełnosprawnością objętych kształceniem specjalnym, nawet o dwa lata ${ }^{74}$. Decyzję podejmuje dyrektor szkoły podstawowej na podstawie składanego przez rodziców wniosku, do którego dołączana jest opinia poradni psychologiczno-pedagogicznej, stwierdzająca potrzebę odroczenia spełniania przez dziecko obowiązku szkolnego w danym roku. Decyzja dotyczy zawsze jednego roku szkolnego, zatem jeśli rodzice dziecka z niepełnosprawnością objętego kształceniem specjalnym ubiegają się o odroczenie w kolejnym, muszą ponownie złożyć wniosek wraz z nową opinią poradni $w$ tej sprawie. Zastosowanie tego mechanizmu wskazuje na konieczność monitorowania postępów dziecka oraz podejmowanie decyzji na podstawie aktualnej oceny jego potrzeb.

Dzieci, u których stwierdzono niepełnosprawność intelektualną w stopniu głębokim, już w wieku trzech lat mogą rozpocząć realizację zajęć rewalidacyjno-wychowawczych ${ }^{75}$. Udział w nich wypełnia obowiązek rocznego przygotowania przedszkolnego, obowiązek szkolny i nauki ${ }^{7}$, jest więc obligatoryjny od 6 do 18 roku życia. Zajęcia te mogą być organizowane do końca roku szkolnego, w którym uczestnik zajęć

Opinia może być wydana przez publiczną albo niepubliczną poradnię psychologiczno-pedagogiczną założoną zgodnie z art. 168 ustawy Prawo oświatowe, zatrudniającą pracowników posiadających kwalifikacje określone dla pracowników publicznych poradni psychologiczno-pedagogicznych.

Art. 36 ust. 1 i 2 ustawy Prawo oświatowe. przez zespół orzekający działający w publicznej poradni psychologiczno-pedagogicznej, w tym specjalistycznej. 
kończy 25 lat. Decyzję o czasie rozpoczęcia i zakończenia uczestnictwa dziecka podejmują rodzice.

Przedłużono możliwość nauki na poszczególnych etapach edukacyjnych uczniom objętym kształceniem specjalnym. W szkole podstawowej może być ono prowadzone do końca roku szkolnego w tym roku kalendarzowym, w którym uczeń kończy 20 lat, a w szkole ponadpodstawowej - 24 lata.

Przewidziano również możliwość przedłużenia okresu kształcenia na poszczególnych etapach edukacyjnych: w szkole podstawowej łącznie o trzy lata (o jeden rok na I i o dwa lata na ll etapie edukacyjnym), a w szkole ponadpodstawowej - o jeden rok ${ }^{77}$. Możliwość ta dotyczy uczniów z niepełnosprawnością objętych kształceniem specjalnym oraz uczniów szkół w zakładach poprawczych i w schroniskach dla nieletnich. Przedłużenie okresu nauki jest instrumentem skierowanym do konkretnego ucznia, a nie do całej klasy - każdorazowo decyzja w tej sprawie powinna być podejmowania z uwzględnieniem jego indywidualnej sytuacji, gdy ma on znaczne trudności w opanowaniu wymagań określonych w podstawie programowej kształcenia ogólnego lub w osiągnięciu efektów kształcenia określonych w podstawie programowej kształcenia w danym zawodzie. Decyzję o przedłużeniu okresu nauki uczniowi z orzeczeniem o potrzebie kształcenia specjalnego wydanym ze względu na niepełnosprawność podejmuje rada pedagogiczna po uzyskaniu opinii zespołu nauczycieli i specjalistów prowadzących z nim zajęcia oraz zgody rodziców albo pełnoletniego ucznia ${ }^{78}$.

Istnieje również możliwość skrócenia okresu kształcenia. Mogą z niej skorzystać uczniowie szczególnie uzdolnieni, którzy realizują indywidualny tok nauki ${ }^{79}$. Są oni klasyfikowani na podstawie egzaminów. po uzyskaniu opinii rady pedagogicznej. Edukacji Narodowej z dnia 9 sierpnia 2017 r. w sprawie warunków i trybu udzielania zezwoleń na indywidualny program lub tok nauki oraz organizacji indywidualnego programu lub toku nauki (Dz.U. poz. 1569). 
Możliwość skrócenia okresu kształcenia, ale tylko w branżowej szkole I stopnia z trzech do dwóch lat ${ }^{80}$, przewidziano w przypadku uczniów szkół działających w:

$\rightarrow$ młodzieżowych ośrodkach wychowawczych lub młodzieżowych ośrodkach socjoterapii, którzy posiadają orzeczenie o potrzebie kształcenia specjalnego wydane ze względu na niedostosowanie społeczne lub zagrożenie niedostosowaniem społecznym,

$\rightarrow$ zakładach poprawczych lub schroniskach dla nieletnich ${ }^{81}$.

Decyzję o skróceniu podejmuje rada pedagogiczna po konsultacjach z rodzicami ucznia oraz po uzyskaniu opinii zespołu nauczycieli i specjalistów prowadzących z nim zajęcia.

\section{Dostosowanie treści nauczania oraz wymagań edukacyjnych}

\section{Treści nauczania}

System oświaty zapewnia dostosowanie treści nauczania82. Dzieci objęte wychowaniem przedszkolnym, niezależnie od tego, czy rozpoznano u nich specjalne potrzeby edukacyjne (z wyjątkiem dzieci z niepełnosprawnością intelektualną w stopniu głębokim), czy nie, realizują tę samą podstawę programową wychowania przedszkolnego ${ }^{83}$. Na poziomie szkoły podstawowej i gimnazjum (do czasu ich wygaszenia) określono odrębną podstawę programową dla uczniów z niepełnosprawnością

80 Pod warunkiem zachowania wymiaru godzin poszczególnych obowiązkowych zajęć edukacyjnych, przewidzianego dla trzyletniego okresu nauczania, z tym, że wymiar godzin zajęć wychowania fizycznego określa art. 28 ust. 2 ustawy Prawo oświatowe.

81 Na podstawie par. 6 rozporządzenia Ministra Edukacji Narodowej w sprawie ramowych planów nauczania dla publicznych szkół.

82 Art. 1 pkt 5 ustawy Prawo oświatowe.

83 Załącznik nr 1 do rozporządzenia Ministra Edukacji Narodowej z dnia 14 lutego 2017 r. w sprawie podstawy programowej wychowania przedszkolnego oraz podstawy programowej kształcenia ogólnego dla szkoły podstawowej, w tym dla uczniów z niepełnosprawnością intelektualną w stopniu umiarkowanym lub znacznym, kształcenia ogólnego dla branżowej szkoły I stopnia, kształcenia ogólnego dla szkoły specjalnej przysposabiającej do pracy oraz kształcenia ogólnego dla szkoły policealnej (Dz.U. poz. 356). 
intelektualną w stopniu umiarkowanym lub znacznym ${ }^{84}$. Na etapie kształcenia ponadpodstawowego lub ponadgimnazjalnego uczniowie ci realizują podstawę programową szkoły specjalnej przysposabiającej do pracy ${ }^{85}$. W tym typie szkoły uczyć się mogą również uczniowie z niepełnosprawnościami sprzężonymi. Pozostali realizują tę samą podstawę programową kształcenia ogólnego określoną dla szkół danego typu ${ }^{86}$ oraz odpowiednio: podstawę programową kształcenia w zawodach 87 lub podstawy kształcenia w zawodach szkolnictwa branżowego ${ }^{88}$. Wybór realizowanej podstawy kształcenia ogólnego wynika zatem z określonego w orzeczeniu poziomu rozwoju intelektualnego ucznia. Wniosek o wydanie orzeczenia składają rodzice ucznia lub pełnoletni uczeń. Mogą oni w każdej chwili wystąpić o zmianę lub uchylenie orzeczenia.

Określoną w załączniku nr 3 do rozporządzenia Ministra Edukacji Narodowejz dnia 14 lutego 2017 r. w sprawie podstawy programowej wychowania przedszkolnego oraz podstawy programowej kształcenia ogólnego dla szkoły podstawowej, w tym dla uczniów z niepełnosprawnością intelektualną w stopniu umiarkowanym lub znacznym, kształcenia ogólnego dla branżowej szkoły I stopnia, kształcenia ogólnego dla szkoły specjalnej przysposabiającej do pracy oraz kształcenia ogólnego dla szkoły policealnej oraz w załączniku nr 3 do Rozporządzenia Ministra Edukacji Narodowej z dnia 27 sierpnia 2012 r. w sprawie podstawy programowej wychowania przedszkolnego oraz kształcenia ogólnego w poszczególnych typach szkół (Dz.U. poz. 977 z późn. zm.).

Określoną w załączniku nr 5 do ww. rozporządzenia z dnia 14 lutego 2017 r. oraz w załączniku nr 7 do ww. rozporządzenia z dnia 27 sierpnia 2012 r.

Załączniki nr 2, 4 i 6 do Rozporządzenia Ministra Edukacji Narodowej z dnia 14 lutego 2017 r. w sprawie podstawy programowej wychowania przedszkolnego oraz podstawy programowej kształcenia ogólnego dla szkoły podstawowej, w tym dla uczniów z niepełnosprawnością intelektualną w stopniu umiarkowanym lub znacznym, kształcenia ogólnego dla branżowej szkoły I stopnia, kształcenia ogólnego dla szkoły specjalnej przysposabiającej do pracy oraz kształcenia ogólnego dla szkoły policealnej oraz załączniki nr 2, 4, 5 i 6 do Rozporządzenia Ministra Edukacji Narodowej z dnia 27 sierpnia 2012 r. w sprawie podstawy programowej wychowania przedszkolnego oraz kształcenia ogólnego w poszczególnych typach szkół (Dz.U. poz. 977 z późn. zm.) - dotyczy tzw. szkół starego typu (sześcioletnia szkoła podstawowa, gimnazjum, zasadnicza szkoła zawodowa, trzyletnie liceum ogólnokształcące, czteroletnie technikum, szkoła policealna).

87 Rozporządzenie Ministra Edukacji Narodowej z dnia 31 marca 2017 r. w sprawie podstawy programowej kształcenia w zawodach (Dz.U. poz. 860).

Rozporządzenie Ministra Edukacji Narodowej z dnia 16 maja 2019 r. w sprawie podstaw programowych kształcenia w zawodach szkolnictwa branżowego oraz dodatkowych umiejętności zawodowych w zakresie wybranych zawodów szkolnictwa branżowego (Dz.U. poz. 991). Dotyczy uczniów, którzy rozpoczynają naukę w szkole prowadzącej kształcenie zawodowe od 1 września 2019 r. 
Programy wychowania przedszkolnego, programy nauczania zajęć edukacyjnych z zakresu kształcenia ogólnego na dany etap edukacyjny oraz programy nauczania zawodu są dopuszczane do użytku w danym przedszkolu, oddziale przedszkolnym w szkole podstawowej, innej formie wychowania przedszkolnego lub w szkole przez dyrektora po zasięgnięciu opinii rady pedagogicznej. Programy te powinny być dostosowane do potrzeb i możliwości uczniów, dla których są przeznaczone.

Dzieci i młodzież z niepełnosprawnością intelektualną w stopniu głębokim realizują indywidualne programy rewalidacyjno-wychowawcze. Ich zakres powinien być dostosowany do poziomu funkcjonowania uczestnika zajęć ${ }^{8} 9$. Nie realizuje on zatem podstawy programowej, nie podlega przepisom w sprawie oceniania, klasyfikowania i promowania, nie otrzymuje świadectwa lub innego równoważnego dokumentu. Nie obowiązuje także podział na poszczególne etapy edukacji, co jest istotne w sytuacji zmiany kwalifikacji orzeczenia o potrzebie zajęć rewalidacyjno-wychowawczych na orzeczenie o potrzebie kształcenia specjalnego. Postulat zmiany tego stanu rzeczy jest zgłaszany przez środowiska pedagogiczne oraz Rzecznika Praw Obywatelskich ${ }^{90}$. Zasadność zastosowania takich rozwiązań w odniesieniu do osób o bardzo niskim poziomie funkcjonowania jest dla części pedagogów kontrowersyjna, biorąc pod uwagę konieczność stawiania wymagań edukacyjnych w sytuacji, gdy często zakres oddziaływań może dotyczyć wąskiego obszaru funkcjonowania. W świetle postanowień ratyfikowanej przez Polskę konwencji ONZ o prawach osób niepełnosprawnych ${ }^{91}$, kwestia ta wymaga pogłębionej analizy i społecznej dyskusji w związku z koniecznością zapewnienia wszystkim osobom z niepełnosprawnością, w tym także intelektualną w stopniu głębokim, równego dostępu do edukacji. Poparcie dla zasadności opracowania jednej podstawy programowej kształcenia ogólnego dla wszystkich uczniów, uwzględniającej szerokie spektrum ich funkcjonowania, zawarto $w$ rekomendacjach organizowania zajęć rewalidacyjno-wychowawczych dla dzieci i młodzieży z upośledzeniem umysłowym w stopniu głębokim (Dz.U. poz. 529). osób z głęboką niepełnosprawnością intelektualną, bit.ly/2K3sqc4 [dostęp: 6.06.2019]. dnia 13 grudnia 2006 r. (Dz.U. z 2012 r. poz. 1169). 
Europejskiej Agencji do spraw Specjalnych Potrzeb i Edukacji Włączającej $(2019$, s. 9).

Uczeń, który przejawia szczególne uzdolnienia, może realizować indywidualny program nauki z jednego, kilku lub wszystkich obowiązujących zajęć edukacyjnych przewidzianych w tygodniowym planie dla danej klasy ${ }^{92}$.

Dla osób podlegających obowiązkowi szkolnemu lub obowiązkowi nauki, które nie opanowały języka polskiego albo znają go na poziomie niewystarczającym do korzystania z nauki³, przewidziano możliwość dodatkowej, bezpłatnej nauki języka polskiego ${ }^{94}$.

W przypadku dzieci i młodzieży z mniejszości narodowych i etnicznych możliwa jest organizacja nauki ich języka ojczystego oraz zajęć z zakresu ich historii i kultury ${ }^{95}$. Decyzja dotycząca udziału dziecka w tych zajęciach należy do rodziców.

Istnieje również możliwość zwolnienia ucznia z realizacji określonych zajęć edukacyjnych ${ }^{9}$. Może ono dotyczyć m.in. nauki drugiego języka nowożytnego w przypadku uczniów z wadą słuchu, z głęboką dysleksją rozwojową, z afazją, z niepełnosprawnościami sprzężonymi lub $z$ autyzmem, w tym z zespołem Aspergera. Zwolnienie następuje wyłącznie na wniosek rodzica i wówczas, gdy takie wskazanie zostato zawarte opinii wydanej uczniowi przez poradnię psychologiczno-pedagogiczną albo w orzeczeniu o potrzebie kształcenia specjalnego lub indywidualnego nauczania. Możliwe jest również zwolnienie z informatyki lub zajęć wychowania fizycznego ${ }^{97}$, albo z wykonywania

Zgodnie z art. 115 ustawy Prawo oświatowe oraz rozporządzeniem w sprawie warunków i trybu udzielania zezwoleń na indywidualny program lub tok nauki oraz organizacji indywidualnego programu lub toku nauki.

Zarówno osób niebędących obywatelami polskimi, jak i obywateli polskich.

94 Zgodnie z art. 165 ust. 7 i 9 ustawy Prawo oświatowe. Dodatkową naukę języka polskiego dla tych osób organizuje organ prowadzący szkołę.

Rozporządzenie Ministra Edukacji Narodowej z dnia 18 sierpnia 2017 r. w sprawie warunków i sposobu wykonywania przez przedszkola, szkoły i placówki publiczne zadań umożliwiających podtrzymywanie poczucia tożsamości narodowej, etnicznej i językowej uczniów należących do mniejszości narodowych i etnicznych oraz społeczności posługującej się językiem regionalnym (Dz.U. poz. 1627). i promowania uczniów i słuchaczy w szkołach publicznych. 
określonych ćwiczeń fizycznych ${ }^{9}$. Stosowne dokumenty przedkładane są przez rodziców.

\section{Dostosowanie warunków i organizacji procesu uczenia się i nauczania}

Dla dzieci objętych wychowaniem przedszkolnym oraz uczniów szkół podstawowych i ponadpodstawowych, którzy w związku z występowaniem niepełnosprawności ${ }^{9}$, niedostosowania społecznego lub zagrożenia niedostosowaniem społecznym ${ }^{100}$ wymagają specjalnej organizacji nauki i metod pracy, organizuje się, zgodnie z decyzją rodziców ${ }^{101}$, kształcenie specjalne ${ }^{102}$. Istnieje możliwość wyboru różnych form jego organizacji: w przedszkolach, szkołach i oddziałach ogólnodostępnych, integracyjnych i specjalnych oraz placówkach specjalnych. Zalecaną formę kształcenia specjalnego wskazuje w orzeczeniu zespół orzekający, jednak decyzja ta należy ostatecznie do rodziców lub pełnoletniego ucznia ${ }^{103}$.

Uczniowie objęci kształceniem specjalnym mogą realizować zajęcia w sposób dostosowany do ich potrzeb na podstawie indywidualnego programu edukacyjno-terapeutycznego: $z$ oddziałem klasowym, w grupie do pięciu osób lub indywidualnie na terenie szkoły. Analogiczne możliwości dotyczą dzieci objętych wychowaniem przedszkolnym.

99 W przepisach prawa oświatowego katalog niepełnosprawności, w związku z którymi organizuje się kształcenie specjalne, jest ściśle określony i dotyczy dzieci i uczniów: niewidomych, słabowidzących, niesłyszących, słabosłyszących, z niepełnosprawnością intelektualną w stopniu lekkim, umiarkowanym i znacznym, z autyzmem, w tym zespołem Aspergera, z niepełnosprawnością ruchową, w tym z afazją, oraz z niepełnosprawnościami sprzężonymi. się wyłącznie z uwagi na niepełnosprawność. W tym wieku nie stwierdza się niedostosowania społecznego lub zagrożenia nim.

101 To rodzice występują o wydanie orzeczenia o potrzebie kształcenia specjalnego. W każdej chwili mogą zmienić zdanie w tej sprawie i złożyć wniosek o zmianę lub uchylenie takiego orzeczenia. 
We wszystkich typach szkół istnieje możliwość organizacji klas terapeutycznych ${ }^{104}$. Ta forma przewidziana jest dla uczniów, którzy wymagają dostosowania organizacji i procesu nauczania oraz długotrwałej pomocy specjalistycznej z uwagi na trudności w funkcjonowaniu wynikające z zaburzeń rozwojowych lub ze stanu zdrowia. Podstawą przyjęcia ucznia do takiej klasy jest opinia poradni psychologiczno-pedagogicznej, z której wynika potrzeba objęcia ucznia pomocą w tej formie.

W szkołach ${ }^{105}$ mogą być również tworzone oddziały przygotowawcze $^{106}$ dla osób ${ }^{107}$ podlegających obowiązkowi szkolnemu lub obowiązkowi nauki, które nie znają języka polskiego albo opanowały go na poziomie niewystarczającym i wymagają dostosowania procesu kształcenia do ich potrzeb i możliwości edukacyjnych.

Stworzono również możliwość kształcenia bez konieczności udziału w obowiązkowych zajęciach edukacyjnych. Korzystają z niej uczniowie realizujący indywidualny tok nauki ${ }^{108}$. Jego organizacja odbywa się na wniosek rodziców, ucznia ${ }^{109}$, wychowawcy klasy lub nauczyciela prowadzącego dane zajęcia ( $w$ takim przypadku konieczna jest zgoda rodziców albo pełnoletniego ucznia).

Dzieci objęte rocznym obowiązkowym wychowaniem przedszkolnym oraz uczniowie szkół wszystkich typów mają możliwość realizowania zindywidualizowanych ścieżek wychowania przedszkolnego

Par. 13 rozporządzenia Ministra Edukacji Narodowej z dnia 9 sierpnia 2017 r. w sprawie zasad organizacji i udzielania pomocy psychologiczno-pedagogicznej w publicznych przedszkolach, szkołach i placówkach oraz par. 8 rozporządzenia Ministra Edukacji Narodowej z dnia 30 kwietnia 2013 r. w sprawie zasad udzielania i organizacji pomocy psychologiczno-pedagogicznej w publicznych szkołach i placówkach. Klas takich nie tworzy się w szkołach specjalnych.

105 Z wyjątkiem szkół artystycznych, specjalnych, sportowych, mistrzostwa sportowego i szkół dla dorosłych.

106 Art. 165 ust. 11-14 ustawy-Prawo oświatowe oraz Rozporządzenia Ministra Edukacji Narodowej z dnia 23 sierpnia 2017 r. w sprawie kształcenia osób niebędących obywatelami polskimi oraz osób będących obywatelami polskimi, które pobierały naukę w szkołach funkcjonujących w systemach oświaty innych państw (Dz.U. poz.1655). zezwoleń na indywidualny program lub tok nauki oraz organizacji indywidualnego programu lub toku nauki. 
lub kształcenia w szkole110. Ta forma kierowana jest do uczniów, którzy mogą uczęszczać do przedszkola lub szkoły, ale ze względu na trudności w funkcjonowaniu nie mogą uczestniczyć we wszystkich zajęciach wraz z rówieśnikami. Organizacja zindywidualizowanych ścieżek odbywa się na wniosek rodzica albo pełnoletniego ucznia i wymaga posiadania opinii publicznej poradni psychologiczno-pedagogicznej. Uczeń, który korzysta z tej ścieżki kształcenia, część zajęć realizuje z klasą, a część indywidualnie z nauczycielem ${ }^{111}$.

Uczniowie, których stan zdrowia znacznie utrudnia lub uniemożliwia uczęszczanie do szkoły, są objęci indywidualnym nauczaniem ${ }^{112}$. Zajęcia organizowane są w miejscu zamieszkania lub pobytu ucznia. Do wniosku o wydanie stosownego orzeczenia oraz zawieszenie lub zaprzestanie organizacji zajęć dołącza się zaświadczenie lekarskie. Dyrektor zobowiązany jest zasięgnąć opinii odpowiednio: rodziców albo pełnoletniego ucznia w zakresie czasu prowadzenia zajęć indywidualnego nauczania, jak i odstąpienia od realizacji niektórych treści nauczania ${ }^{113}$. Na wniosek rodziców tygodniowy wymiar godzin tych zajęć może być niższy niż minimalne wymagania określone w przepisach (np. w sytuacji, gdy stan zdrowia znacznie ogranicza dziecku możliwość udziału w zajęciach). W uzgodnieniu z rodzicami albo z pełnoletnim uczniem podejmowane są także działania umożliwiające mu kontakt z kolegami z klasy. Analogiczne regulacje dotyczą organizacji indywidualnego rocznego przygotowania przedszkolnego.

Rozwiązanie to nie obejmuje dzieci i uczniów objętych kształceniem specjalnym - dostosowanie organizacji w ich przypadku następuje na podstawie ustaleń zawartych w indywidualnych programach edukacyjno-terapeutycznych. Ścieżek takich nie stosuje się zatem w przedszkolach i szkołach specjalnych.

Par. 12 rozporządzenia Ministra Edukacji Narodowej z dnia 9 sierpnia 2017 r. w sprawie zasad organizacji i udzielania pomocy psychologiczno-pedagogicznej w publicznych przedszkolach, szkołach i placówkach oraz par. 13b rozporządzenia Ministra Edukacji Narodowej z dnia 30 kwietnia 2013 r. w sprawie zasad udzielania i organizacji pomocy psychologiczno-pedagogicznej w publicznych szkołach i placówkach.

Art. 127 ustawy Prawo oświatowe oraz rozporządzeń Ministra Edukacji Narodowej: z dnia 9 sierpnia 2017 r. w sprawie indywidualnego obowiązkowego rocznego przygotowania przedszkolnego dzieci i indywidualnego nauczania dzieci i młodzieży oraz z dnia 28 sierpnia 2014 r. w sprawie indywidualnego obowiązkowego rocznego przygotowania przedszkolnego dzieci i indywidualnego nauczania dzieci i młodzieży. 
W szkołach podstawowych mogą być tworzone oddziały przysposabiające do pracy ${ }^{114}$. Przeznaczone są dla uczniów w wieku powyżej 15 lat, którzy otrzymali promocję do klasy VII albo nie uzyskali do klasy VIII i mogą mieć trudności z ukończeniem szkoły w normalnym trybie ${ }^{115}$. Naukę $w$ tych oddziałach realizuje się zgodnie $z$ podstawą programową kształcenia ogólnego dostosowaną do potrzeb i możliwości uczniów. Przyjęcie do takiego oddziału wymaga opinii lekarza oraz poradni psychologiczno-pedagogicznej. Dokumenty te wydawane są wyłącznie na wniosek rodzica lub pełnoletniego ucznia.

\section{Podręczniki i materiały dydaktyczne}

Dostosowanie procesu kształcenia obejmuje również odpowiedni do potrzeb edukacyjnych uczniów dobór podręczników, materiałów edukacyjnych i ćwiczeniowych, a także ich formy (papierowa, elektroniczna). Nauczyciel ma w tym zakresie dużą autonomię. Może zdecydować o realizacji programu nauczania z zastosowaniem podręcznika, materiału edukacyjnego lub materiału ćwiczeniowego albo zrezygnować z ich stosowania ${ }^{116}$. Wybierając materiały dydaktyczne dla uczniów z niepełnosprawnością objętych kształceniem specjalnym, nauczyciele zobowiązani są do uwzględniania ich potrzeb edukacyjnych i możliwości psychofizycznych ${ }^{117}$. Na zakup podręczników, materiałów edukacyjnych i ćwiczeniowych dostosowanych do potrzeb tych uczniów przeznaczane są zwiększone środki w ramach dotacji celowej ${ }^{118}$. Nauczyciele mogą również korzystać z przygotowanych na zlecenie Ministerstwa Edukacji Narodowej podręczników, materiałów edukacyjnych oraz książek pomocniczych, dostosowanych do potrzeb uczniów z niepełnosprawnością ${ }^{119}$.

Par. 16 rozporządzenia Ministra Edukacji Narodowej w sprawie szczegółowej organizacji publicznych szkół i publicznych przedszkoli. Art. 22ab ust. 1 ustawy o systemie oświaty (Dz.U. poz. 1591 z późn. zm.).

117 Tamże, art. 22ab ust. 3.

118 Art. 55 ust. 6 ustawy o finansowaniu zadań oświatowych.

119 Adaptacje podręczników szkolnych i książek pomocniczych, dostosowane do potrzeb uczniów niewidomych, słabowidzących i niesłyszących, bit.ly/2Wrsp38 [dostęp: 6.06.2019]. 


\section{Wsparcie dodatkowej kadry}

Przepisy prawa oświatowego umożliwiają zatrudnianie osób wspierających organizację kształcenia specjalnego: nauczycieli posiadających przygotowanie w zakresie pedagogiki specjalnej, specjalistów oraz pomocy nauczyciela.

W przedszkolach ogólnodostępnych z oddziałami integracyjnymi, przedszkolach integracyjnych, szkołach ogólnodostępnych z oddziałami integracyjnymi i szkołach integracyjnych zatrudnia się dodatkowo nauczycieli posiadających kwalifikacje w zakresie pedagogiki specjalnej, którzy współorganizują proces edukacyjny z uwzględnieniem zaleceń zawartych w orzeczeniu o potrzebie kształcenia specjalnego.

Dodatkową kadrę obowiązkowo zatrudnia się także w szkołach ogólnodostępnych, do których uczęszczają uczniowie posiadający orzeczenie o potrzebie kształcenia specjalnego wydane ze względu na autyzm, w tym zespół Aspergera, albo niepełnosprawności sprzężone. Kadra ta, w zależności od potrzeb, składa się z nauczycieli posiadających kwalifikacje w zakresie pedagogiki specjalnej, specjalistów lub pomocy nauczyciela. Zajęcia edukacyjne oraz zintegrowane działania i określone w programie lekcje, realizowane wspólnie z innymi nauczycielami przez dodatkowo zatrudnione osoby wyznacza dyrektor szkoły, kierując się potrzebami uczniów. W ocenie tych potrzeb oraz efektywności udzielonego wsparcia mają prawo uczestniczyć rodzice i sami uczniowie. Analogiczne przepisy obowiązują również w przedszkolach ogólnodostępnych oraz w innych formach wychowania przedszkolnego.

Rodzice dziecka posiadającego orzeczenie o niepełnosprawności lub stopniu niepełnosprawności ${ }^{120}$ mogą ponadto wystąpić do właściwego ośrodka pomocy społecznej z wnioskiem o zatrudnienie asystenta osoby niepełnosprawnej ${ }^{121}$.

Wszyscy uczniowie podlegający obowiązkowi szkolnemu lub obowiązkowi nauki (także cudzoziemcy), którzy nie znają języka polskiego albo znają go na poziomie niewystarczającym, mogą skorzystać z pomozawodowej i społecznej oraz zatrudnianiu osób niepełnosprawnych (Dz.U. z 2018 r. poz. 511 z późn. zm.) oraz Rozporządzenia Ministra Gospodarki, Pracy i Polityki Społecznej z dnia 15 lipca 2003 r. w sprawie orzekania o niepełnosprawności i stopniu niepełnosprawności (Dz.U. z 2018 r. poz. 2027). 
cy osoby władającej językiem kraju pochodzenia. Zatrudnia ją dyrektor szkoły w charakterze pomocy nauczyciela na okres nie dłuższy niż 12 miesięcy ${ }^{122}$. Takie regulacje nie istnieją w odniesieniu do przedszkoli.

Do wspomagania nauczyciela mogą także być zatrudniani w przedszkolach i szkołach publicznych asystenci edukacji romskiej, którzy udzielają dzieciom i młodzieży pochodzenia romskiego pomocy w kontaktach ze środowiskiem przedszkolnym lub szkolnym, ponadto współpracują z ich rodzicami oraz z przedszkolem lub szkołą ${ }^{123}$.

\section{Oddziaływania o charakterze edukacyjnym, doradczym, wspierającym rozwój lub terapeutycznym}

W przepisach określono wiele możliwości rozwijania zainteresowań, zdolności, umiejętności i kompetencji uczniów, a także niwelowania występujących deficytów i zaburzeń rozwojowych.

\section{Oferta przedszkoli, szkół i placówek}

Nauczyciele, opiekunowie grup wychowawczych oraz specjaliści zobowiązani są do udzielania pomocy psychologiczno-pedagogicznej podczas bieżącej pracy z uczniami. Jest to bardzo ważny i najbardziej dostępny instrument wsparcia, jednakże aby był skuteczny, trzeba go realizować na podstawie jasno zdefiniowanych celów. Konieczne jest także monitorowanie postępów uczniów. W przepisach wskazano również jeszcze jedno ważne narzędzie - zintegrowane działania nauczycieli i specjalistów. Przykładem mogą być prace ukierunkowane na wzmacnianie poczucia własnej wartości ucznia, nagradzanie pożądanych zachowań czy rozwijanie jego kompetencji komunikacyjnych, które są realizowane przez wszystkich nauczycieli w trakcie lekcji oraz podczas zajęć świetlicowych. W przypadku ucznia z niepełnosprawnością będą to działania o charakterze rewalidacyjnym, ucznia niedostowarunków i sposobu wykonywania przez przedszkola, szkoły i placówki publiczne zadań umożliwiających podtrzymywanie poczucia tożsamości narodowej, etnicznej i językowej uczniów należących do mniejszości narodowych i etnicznych oraz społeczności posługującej się językiem regionalnym (Dz.U. poz. 1627). 
sowanego społecznie - resocjalizacyjnym, a zagrożonego niedostosowaniem społecznym - socjoterapeutycznym ${ }^{124}$.

W ramach zajęć świetlicowych mogą być prowadzone różnorodne zajęcia uwzględniające potrzeby edukacyjne oraz rozwojowe uczniów, ukierunkowane na rozwijanie zainteresowań uczniów, wspieranie rozwoju fizycznego czy pomoc w odrabianiu lekcji125.

Przedszkola, szkoły i placówki zapewniają również szeroki wachlarz zajęć z zakresu pomocy psychologiczno-pedagogicznej ${ }^{126}$. Dla uczniów napotykających trudności w uczeniu się, szczególnie w spełnianiu wymagań edukacyjnych wynikających z podstawy programowej kształcenia ogólnego dla danego etapu edukacyjnego, organizuje się zajęcia dydaktyczno-wyrównawcze. Dostępne są też zajęcia rozwijające zainteresowania i uzdolnienia, które służą zwłaszcza kształtowaniu aktywności i kreatywności uczniów, realizowane np. w ramach warsztatów, kółek zainteresowań, gier terenowych czy zajęć plenerowych. Przepisy nie precyzują ich zakresu i formy, pozostawiając przestrzeń na dostosowanie ich do potrzeb konkretnych uczniów. Zajęcia rozwijające umiejętności uczenia się powinny być dostępne dla wszystkich dzieci, a nie tylko dla tych, które mają trudności w nauce. Ich celem jest bowiem przekazanie technik skutecznego uczenia się, których znajomość jest niezbędna na każdym etapie kształcenia. W przedszkolach, szkołach i placówkach mogą być również organizowane różnego rodzaju zajęcia specjalistyczne, np. korekcyjno-kompensacyjne, logopedyczne, rozwijające kompetencje emocjonalno-społeczne.

Dla dzieci i uczniów z niepełnosprawnością organizowane są różnego rodzaju zajęcia rewalidacyjne ${ }^{127}$, których rodzaj oraz forma (indywi-

124 Na podstawie rozporządzeń Ministra Edukacji Narodowej w sprawie warunków organizowania kształcenia, wychowania i opieki dla dzieci i młodzieży niepełnosprawnych, niedostosowanych społecznie i zagrożonych niedostosowaniem społecznym: z dnia 9 sierpnia 2017 r. oraz z dnia 24 lipca 2015 r.

Art. 105 ust. 2 ustawy Prawo oświatowe.

Na podstawie przepisów rozporządzeń Ministra Edukacji Narodowej z dnia 9 sierpnia 2017 r. w sprawie zasad organizacji i udzielania pomocy psychologiczno-pedagogicznej w publicznych przedszkolach, szkołach i placówkach oraz z dnia 30 kwietnia 2013 r. w sprawie zasad udzielania i organizacji pomocy psychologiczno-pedagogicznej w publicznych szkołach i placówkach. w sprawie warunków organizowania kształcenia, wychowania i opieki dla dzieci i młodzieży niepełnosprawnych, niedostosowanych społecznie i zagrożonych niedostosowaniem społecznym: z dnia 9 sierpnia 2017 r. oraz z dnia 24 lipca 2015 r. 
dualna lub grupowa) powinny być dostosowane do potrzeb odbiorcy. Ich katalog nie jest zamknięty, a wyróżnić warto: naukę orientacji przestrzennej i poruszania się, systemu Braille'a, języka migowego lub innych sposobów komunikowania się (szczególnie wspomagających) i alternatywnych metod komunikacji (AAC), spotkania rozwijające umiejętności społeczne. Część zajęć rewalidacyjnych, podobnie jak specjalistycznych z zakresu pomocy psychologiczno-pedagogicznej, ma charakter terapeutyczny. Różnią się tym, że te pierwsze obejmują wyłącznie uczniów z niepełnosprawnością, w związku z czym w ich trakcie stosowane są metody pracy uwzględniające specyficzne potrzeby osób z tej grupy.

Uczniowie zagrożeni niedostosowaniem społecznym mogą skorzystać z zajęć socjoterapeutycznych, a niedostosowani społecznie - z resocjalizacyjnych ${ }^{28}$.

Przedszkola, oddziały przedszkolne w szkołach podstawowych i inne formy wychowania przedszkolnego oraz szkoły, z wyjątkiem szkół artystycznych, zobowiązane są do prowadzenia systematycznych działań w zakresie doradztwa zawodowego. Mają one na celu wspieranie wychowanków w procesie rozpoznawania zainteresowań i predyspozycji oraz podejmowania przez nich świadomych wyborów edukacyjnych i zawodowych ${ }^{129}$. Dla uczniów szkół podstawowych oraz ponadpodstawowych organizuje się zajęcia z zakresu doradztwa zawodowego.

\section{Oferta poradni psychologiczno-pedagogicznych}

Pomoc poradni psychologiczno-pedagogicznych może być pośrednia i bezpośrednia ${ }^{130}$. Ta pierwsza polega na wydaniu dokumentu (orzeczenia, opinii, informacji), który inicjuje proces udzielania wsparcia w przedszkolu, szkole, placówce, do której uczęszcza uczeń. Posiadanie opinii poradni lub orzeczenia wydanego przez zespół orzekający działający w publicznej poradni psychologiczno-pedagogicznej jest często warunkiem niezbędnym do zapewnienia konkretnych form pomocy psychologiczno-pedagogicznej lub dostosowania organizacji kształcenia. 12 lutego 2019 r. w sprawie doradztwa zawodowego (Dz.U. poz. 325). zasad działania publicznych poradni psychologiczno-pedagogicznych, w tym publicznych poradni specjalistycznych (Dz.U. poz. 199 oraz z 2017 r. poz. 1647). 
Pomoc bezpośrednia kierowana jest do dzieci wymagających wsparcia psychologiczno-pedagogicznego lub wsparcia w wyborze kierunku kształcenia i zawodu oraz planowaniu kariery. Poradnie oferują pomoc w różnych formach (katalog jest otwarty): indywidualnej i grupowej terapii dzieci i młodzieży, terapii rodzin, interwencji kryzysowej, grup wsparcia, warsztatów, porad i konsultacji.

\section{Pomoc materialna}

Ważnym instrumentem wsparcia ucznia jest pomoc materialna. Ma ona charakter socjalny (stypendium szkolne, zasiłek szkolny) lub motywacyjny (stypendium za wyniki w nauce lub osiągnięcia sportowe oraz stypendia przyznawane przez Prezesa Rady Ministrów, ministra właściwego do spraw oświaty i wychowania, ministra właściwego do spraw kultury i dziedzictwa narodowego) ${ }^{131}$.

\section{Podsumowanie}

Niniejszy przegląd, mimo że obejmuje jedynie wybrane instrumenty wsparcia, jasno wskazuje, że istnieje wiele możliwości w zakresie tworzenia zindywidualizowanych planów wspierania uczniów o zróżnicowanych potrzebach rozwojowych i edukacyjnych w procesie kształcenia i wychowania. Istotne jest rozwijanie umiejętności nauczycieli i specjalistów oraz kadry zarządzającej placówkami edukacyjnymi, by potrafili je wykorzystywać w sposób, który nie wyłącza uczniów z grupy rówieśniczej, lecz wzmacnia ich zaangażowanie i uczestnictwo oraz pozytywne relacje koleżeńskie. Upowszechnianie wiedzy na temat biopsychospołecznych uwarunkowań potrzeb rozwojowych i edukacyjnych oraz rozwijanie umiejętności jej zastosowania w procesie planowania wsparcia powinno być uwzględnione zarówno w programach studiów przygotowujących do wykonywania zawodu nauczyciela, jak i w odpowiedniej ofercie placówek doskonalenia nauczycieli (Hagiwara i in. 2019, s. 15). Konieczne są również działania, które zapewnią dziecku realny dostęp do pomocy wysokiej jakości w jego najbliższym otoczeniu oraz w jak najkrótszym czasie od momentu rozpoznania takiej potrzeby. 



\subsubsection{Uniwersalne projektowanie zajęć jako droga do zaspokajania zróżnicowanych potrzeb edukacyjnych}

Katarzyna Cichocka-Segiet, Piotr Mostowski, Paweł Rutkowski

Początki projektowania uniwersalnego związane są ściśle z dziedziną architektury. Podstawowym założeniem zaproponowanej przez architekta Ronalda L. Mace'a koncepcji projektowania globalnego było uczynienie otoczenia dostępnym dla jak najszerszej grupy użytkowników. Plan odpowiadający takim standardom nie wymaga dalszych adaptacji, zachowując jednocześnie walory estetyczne. Warto podkreślić, że uwzględnienie potrzeb konkretnej grupy użytkowników często przynosi zysk również innym (np. obniżone krawężniki są udogodnieniem nie tylko dla ludzi poruszających się na wózkach, lecz także dla osób starszych, dostawców). W latach 90. XX wieku w Centrum Projektowania Uniwersalnego (Uniwersytet Karoliny Północnej) opracowano podstawowe zasady opisanego wyżej podejścia do projektowania, dotyczące m.in. równego dostępu, elastyczności, prostoty i niewyszukania, odpowiedniego środowiska, zrozumiałości informacji czy ograniczenia koniecznego wysiłku fizycznego (dokładny opis tych wytycznych wraz z przykładami: Connell i in. 1997). Z czasem założenia projektowania uniwersalnego zaczęły przenikać do obszarów takich jak wzornictwo przemysłowe, interfejsy komputerowe, strony i serwisy internetowe, technologie komunikacyjne itp. (Adaszyńska 2017, s. 16-17). W latach 90. ubiegłego wieku zaczęto również używać określenia „projektowanie uniwersalne w nauczaniu” (UDL, Universal Design for Learning). Głównym podmiotem stojącym za przeniesieniem idei projektowania uniwersalnego na grunt edukacji była amerykańska organizacja CAST (Center for Applied Special Technology) (Fedorowicz 2007, s. 401). UDL jest modelem opracowywania procesu nauczania w taki sposób, aby uwzględniał on potrzeby jak 
największej grupy odbiorców. Założenia UDL oparte są na wnioskach z badań pedagogicznych, psychologicznych, a nawet neurobiologicznych (por. np. Domagała-Zyśk 2015, s. 554). Podstawą UDL jest konstatacja, że ludzie uczą się na różne sposoby i różnorodność ta powinna być uwzględniona w środowisku edukacyjnym od początku nauki (Gronneberg, Johnston 2015). Wszyscy powinni móc w pełni uczestniczyć w procesie dydaktycznym bez obniżania jego standardów. Chociaż UDL z założenia dotyczy ogółu uczniów, jest ono szczególnie istotne dla tych ze specjalnymi potrzebami edukacyjnymi. Implementacja tego rozwiązania jest zatem właściwie nieodzowna w modelu edukacji włączającej.

Jak pokazuje m.in. opracowanie przygotowane przez Teaching Excellence in Adult Literacy Center (TEAL 2010), uniwersalne projektowanie w nauczaniu wymaga stosowania różnorodnych i elastycznych metod:

$\rightarrow$ prezentacji informacji lub umożliwienia dostępu do nich (nacisk na to, CZEGO uczymy),

$\rightarrow$ planowania i wykonywania zadań (nacisk na to, JAK uczymy),

$\rightarrow$ angażowania uczniów w proces uczenia się (nacisk na to, DLACZEGO uczymy).

Te trzy aspekty przekładają się na następujące oczekiwania kierowane pod adresem procesu dydaktycznego, tj. na wiele sposobów:

$\rightarrow$ przedstawiania (różne metody prezentowania informacji, zapewnienie wsparcia),

$\rightarrow$ działania i ekspresji (dostarczanie uczącym się alternatywnych sposobów prezentowania swoich umiejętności i wiedzy),

$\rightarrow$ angażowania (wykorzystanie zainteresowań uczniów przy wyborze treści i narzędzi edukacyjnych, motywowanie uczniów poprzez dostosowywanie poziomu wyzwań).

Tabela 1 przedstawia listę wytycznych uniwersalnego projektowania w nauczaniu opracowanych przez CAST (2018a). W polskim tłumaczeniu zastosowaliśmy bezpośredni zwrot $w$ drugiej osobie liczby pojedynczej, dzięki czemu wytyczne zachowują charakter instrukcji i mogą służyć jako lista kontrolna. Zapisy na liście mają charaktery syntetyczny, gdyż ich celem jest zasygnalizowanie poszczególnych zagadnień. Szczegółowe opisy dotyczące każdego z punktów wraz z przykładami można znaleźć na stronie internetowej UDL Guidelines`. 
Tabela 1. Wytyczne uniwersalnego projektowania w nauczaniu

\begin{tabular}{|c|c|c|}
\hline $\begin{array}{l}\text { I. ZAPEWNIAJ ZRÓŻNICOWANE } \\
\text { SPOSOBY PREZENTOWANIA TREŚCI }\end{array}$ & $\begin{array}{l}\text { II. ZAPEWNIAJ WIELE MOŻLIWOŚCI } \\
\text { DZIAŁANIA I EKSPRESJI }\end{array}$ & $\begin{array}{l}\text { III. ZAPEWNIAJ WIELE SPOSOBÓW } \\
\text { ANGAŻOWANIA }\end{array}$ \\
\hline $\begin{array}{l}\text { 1. Umożliwiaj wybór w zakre- } \\
\text { sie percepcji: } \\
\text { 1.1. Zapewniaj możliwości } \\
\text { dostosowań w zakresie } \\
\text { wzrokowego odbioru informacji, } \\
\text { 1.2. Udostępniaj alternatywę } \\
\text { dla treści dźwiękowych, } \\
\text { 1.3. Udostępniaj alternatywę } \\
\text { dla treści wizualnych. }\end{array}$ & $\begin{array}{l}\text { 4. Dawaj wybór w zakresie } \\
\text { fizycznego działania: } \\
\text { 4.1. Różnicuj metody reagowa- } \\
\text { nia i nawigowania, } \\
\text { 4.2. Optymalizuj dostęp } \\
\text { do narzędzi i technologii } \\
\text { wspomagających. }\end{array}$ & $\begin{array}{l}\text { 7. Stwarzaj warunki do roz- } \\
\text { budzania zainteresowania: } \\
\text { 7.1. Wspieraj indywidualne } \\
\text { wybory i autonomię, } \\
\text { 7.2. Dbaj o istotność, warto- } \\
\text { ściowość i autentyczność, } \\
\text { 7.3. Minimalizuj zagrożenia } \\
\text { i dystraktory. }\end{array}$ \\
\hline $\begin{array}{l}\text { 2. Zapewniaj różne możliwości } \\
\text { w zakresie języka, wyrażeń } \\
\text { matematycznych i symboli: } \\
\text { 2.1. Wyjaśniaj słownictwo } \\
\text { i symbole, } \\
2.2 \text { Objaśniaj składnię i struktu- } \\
\text { rę tekstu, } \\
\text { 2.3. Wspieraj odczytywanie } \\
\text { tekstu, notacji matematycznej } \\
\text { i symboli, } \\
\text { 2.4. Zachęcaj do rozwijania } \\
\text { komunikacji międzyjęzykowej, } \\
\text { 2.5. Wykorzystuj różne media } \\
\text { do ilustrowania treści. }\end{array}$ & $\begin{array}{l}\text { 5. Zapewniaj zróżnicowa- } \\
\text { ne możliwości ekspresji } \\
\text { i komunikacji: } \\
\text { 5.1. Korzystaj z różnych } \\
\text { mediów do komunikacji, } \\
\text { 5.2. Korzystaj z różnych } \\
\text { narzędzi do tworzenia } \\
\text { i łączenia komunikatów, } \\
\text { 5.3. Rozwijaj umiejętności } \\
\text { na podstawie praktyki. }\end{array}$ & $\begin{array}{l}\text { 8. Zapewniaj możliwość } \\
\text { trwałego wysiłku i budowa- } \\
\text { nia wytrwałości: } \\
\text { 8.1. Uwydatniaj cele } \\
\text { i zadania, } \\
\text { 8.2. Optymalizuj wyzwania } \\
\text { przez różnicowanie oczeki- } \\
\text { wań i dostępnych zasobów, } \\
\text { 8.3. Wspieraj współpracę } \\
\text { i twórz społeczność, } \\
\text { 8.4. Zwiększaj liczbę infor- } \\
\text { macji zwrotnych. }\end{array}$ \\
\hline $\begin{array}{l}\text { 3. Zapewniaj różne możliwości } \\
\text { w zakresie rozumienia: } \\
\text { 3.1. Aktywizuj i poszerzaj } \\
\text { wiedzę ogólną, } \\
\text { 3.2. Podkreślaj wzorce, najważ- } \\
\text { niejsze cechy, nadrzędne idee } \\
\text { i istniejące relacje, } \\
\text { 3.3. Udzielaj wskazówek doty- } \\
\text { czących przetwarzania i wizuali- } \\
\text { zacji informacji oraz operowania } \\
\text { nimi. }\end{array}$ & $\begin{array}{l}\text { 6. Zapewniaj różne moż- } \\
\text { liwości w zakresie funk- } \\
\text { cji wykonawczych: } \\
\text { 6.1. Udzielaj wskazówek doty- } \\
\text { czących właściwego wybiera- } \\
\text { nia celów, } \\
\text { 6.2. Wspieraj rozwijanie strate- } \\
\text { gii i planowanie, } \\
\text { 6.3. Pomagaj w zarządzaniu } \\
\text { informacją i zasobami, } \\
\text { 6.4. Zwiększaj możliwość } \\
\text { monitorowania postępów. }\end{array}$ & $\begin{array}{l}\text { 9. Zapewniaj warun- } \\
\text { ki samoregulacji: } \\
\text { 9.1. Promuj motywujące } \\
\text { oczekiwania i przekonania, } \\
\text { 9.2. Wspieraj indywidualne } \\
\text { umiejętności i strategie } \\
\text { rozwiązywania problemów, } \\
\text { 9.3. Zachęcaj do samooceny } \\
\text { i autorefleksji. }\end{array}$ \\
\hline Uczniowie zaradni i kompetentni & $\begin{array}{l}\text { Uczniowie planujący } \\
\text { i ukierunkowani na cel }\end{array}$ & $\begin{array}{l}\text { Uczniowie zmotywowani } \\
\text { i świadomi celu }\end{array}$ \\
\hline
\end{tabular}

Źródło: CAST 2018a ([za: Rao, Meo 2016, s. 2; tłumaczenie i opracowanie własne]).

Listę podzielono zgodnie z trzema głównymi zasadami uniwersalnego projektowania w nauczaniu. Każda kategoria powiązana jest z odrębnymi sieciami neuronowymi aktywnymi w mózgu i odpowiedzialnymi kolejno za zrozumienie, planowanie strategiczne i afektywność (CAST 2018b). Tym samym UDL uwzględnia sposób, w jaki nasz mózg przyswaja nowe informacje, przetwarza je i zapamiętuje. 
Trzydzieści jeden punktów pogrupowanych w dziewięciu kategoriach i trzech zestawach pozwala nauczycielowi już na etapie planowania zajęć uwzględnić zróżnicowane potrzeby uczniów, a tym samym stworzyć w pełni inkluzywne środowisko edukacyjne. Przeprowadzone dotychczas badania skuteczności UDL pokazują, że uczniowie biorący udział w procesie nauczania uwzględniającym te wytyczne uzyskują lepsze wyniki oraz są bardziej zmotywowani i zaangażowani (Rao, Meo 2016, s. 3). Kluczowe wydaje się w tym kontekście postrzeganie kształcenia (nauczania/uczenia się) jako procesu nabywania wiedzy, umiejętności i kompetencji.

Przygotowywanie zajęć dydaktycznych z uwzględnieniem uniwersalnego projektowania w nauczaniu należy rozbić na dwa etapy (Rao, Meo 2016, s. 4). Pierwszy z nich to analiza zapisów zawartych w podstawie programowej i w szczegółowych planach nauczania, dotycząca wiedzy i umiejętności, które powinien przyswoić uczeń. Ważne jest, aby maksymalnie doprecyzować użyte $w$ tych dokumentach sformułowania o charakterze ogólnym. Dzięki właściwemu zidentyfikowaniu istotnych umiejętności i wiedzy możemy przejść do szczegółowego planowania lekcji. Identyfikacja wiedzy i umiejętności wiąże się ściśle z procesem diagnozy edukacyjnej, rozumianej jako "poszukiwanie odpowiedzi na pytanie: jak przebiega proces (ten, który stanowi podstawę działań mających przynieść określony wynik), jakie ewentualnie pojawiają się zaburzenia w przebiegu tego procesu" (Hajnicz 2010, s. 34). Dopiero w wyniku diagnozy sformułowane może zostać zadanie "postrzegane z punktu widzenia procesów, które angażuje, a nie z punktu widzenia wyniku, do którego ma prowadzić" (tamże, s. 35). Podjęcie opisanych tu działań jest punktem wyjścia do szczegółowego przygotowania lekcji. UDL można wykorzystać przy planowaniu każdego elementu związanego z organizacją i przebiegiem zajęć. W literaturze przedmiotu wyróżnia się często cztery główne komponenty lekcji (por. Rao, Meo 2016, s. 5): określenie celów zajęć, które odpowiadają podstawie programowej, opracowanie strategii instruktażowej (metody), wybór zasobówi materiałów oraz ocenianie postępówi wynikówuczniów. Przy analizie każdego z tych elementów można posłużyć się odpowiednimi pytaniami pomocniczymi (zob. tabela 2). 
Tabela 2. Zastosowanie UDL dla wybranych komponentów lekcji

\begin{tabular}{|c|c|}
\hline KOMPONENT LEKCJI & PYTANIA POMOCNE PRZY PROJEKTOWANIU Z WYKORZYSTANIEM UDL \\
\hline Cele & $\begin{array}{l}\text { Jakie umiejętności i wiedzę uczniowie powinni przyswoić (zgodnie z wymoga- } \\
\text { mi podstawy programowej)? }\end{array}$ \\
\hline Ocenianie & Jak uczniowie mogą pokazać, że osiągnęli wyznaczone cele? \\
\hline Metody & $\begin{array}{l}\text { Jakie wsparcie można zapewnić w ramach instruowania, aby uczniowie } \\
\text { przyswoili materiał i zaprezentowali swoją wiedzę? }\end{array}$ \\
\hline Materiały & $\begin{array}{l}\text { Jakie zasoby, materiały i narzędzia mogą zostać użyte, aby zapewnić zróżni- } \\
\text { cowane sposoby prezentowania informacji oraz zainteresować przedstawia- } \\
\text { nymi treściami? }\end{array}$ \\
\hline
\end{tabular}

Źródło: Rao, Meo 2016, s. 5 (tłumaczenie i opracowanie własne).

Wszystkie kroki projektowania zajęć z wykorzystaniem UDL przedstawia rys. 1. Szczegółowy opis każdego z nich można znaleźć w pracy Rao, Meo (2016).

Rysunek 1. Cykl projektowania zajęć z wykorzystaniem UDL

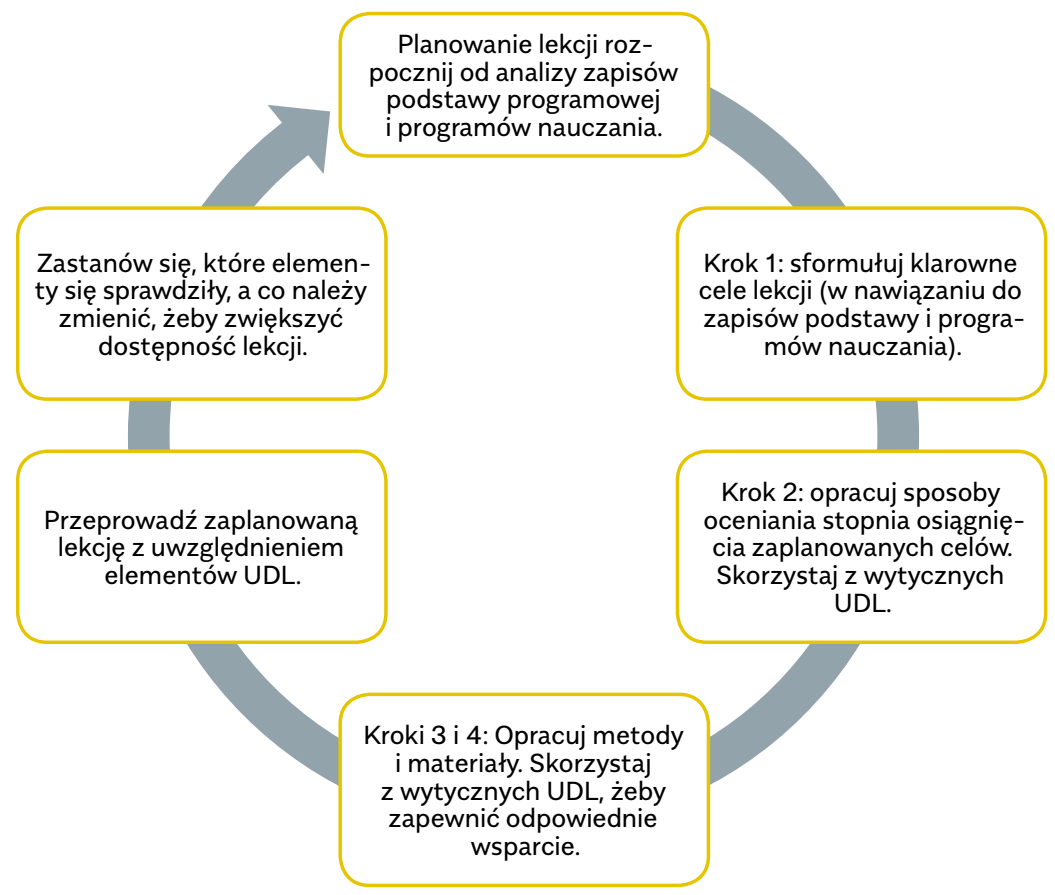

Źródło: Rao, Meo 2016, s. 5 (tłumaczenie i opracowanie własne). 
Zgodnie ze swoją nazwą projektowanie uniwersalne w nauczaniu może być stosowane w każdym środowisku edukacyjnym. Powinno ono prowadzić do zaspokojenia potrzeb wynikających ze zróżnicowań w zakresie statusu socjoekonomicznego, kulturowego i zdrowotnego uczniów. Nie zawsze udaje się ten postulat w pełni zrealizować, ale należy dokładać starań, by beneficjentów było możliwie wielu, a najlepiej, by korzyści odnieśli wszyscy uczestnicy procesu nauczania. Chociaż w założeniach UDL nie precyzuje się docelowej grupy, to z reguły podejście to kojarzone jest z osobami ze specjalnymi potrzebami edukacyjnymi, często z zawężeniem do uczniów z niepełnosprawnościami. Posiadają oni orzeczenie o potrzebie kształcenia specjalnego, wydane z uwagi na niepełnosprawność przez zespół orzekający działający w publicznej poradni psychologiczno-pedagogicznej. Rozporządzenie Ministra Edukacji Narodowej z dnia 9 sierpnia 2017 r. w sprawie warunków organizowania kształcenia, wychowania i opieki dla dzieci i młodzieży niepełnosprawnych, niedostosowanych społecznie i zagrożonych niedostosowaniem społecznym (Dz.U. z 2017 r. poz. 1578) określa, że kształcenie specjalne organizuje się dla następujących grup uczniów:

$\rightarrow$ niesłyszących,

$\rightarrow$ słabosłyszących,

$\rightarrow$ niewidomych,

$\rightarrow$ słabowidzących,

$\rightarrow$ z niepełnosprawnością ruchową ( $w$ tym z afazją),

$\rightarrow$ z niepełnosprawnością intelektualną $\mathrm{w}$ stopniu lekkim, umiarkowanym lub znacznym,

$\rightarrow$ z autyzmem, $w$ tym z zespołem Aspergera,

$\rightarrow$ z niepełnosprawnościami sprzężonymi.

Trudno wyobrazić sobie stworzenie jednolitej listy potrzeb edukacyjnych, która dotyczyłaby każdej z wymienionych grup. Na przykład uczniowie głusi posługujący się polskim językiem migowym (PJM) mają zupełnie inne potrzeby komunikacyjne niż uczniowie niewidomi, których językiem rodzimym jest polszczyzna. Udogodnienia przestrzenne dla uczniów z niepełnosprawnością ruchową nie są z kolei niezbędne dla pozostałych grup wymienionych wyżej. Warto jednak pamiętać o jednym z kluczowych założeń projektowania uniwersalnego - to, co jest dobre dla konkretnych odbiorców, może przynieść korzyści wszystkim. Upraszczanie złożonych struktur składniowych w tekście 
- przy zachowaniu jego warstwy merytorycznej - będzie ułatwiało lekturę zarówno uczniom głuchym, jak i osobom z niepełnosprawnością intelektualną w stopniu lekkim czy z trudnościami w porozumiewaniu się słownym (określanym także mianem dzieci ze złożonymi potrzebami komunikacyjnymi - complex communication needs). Obszerna lista wytycznych przedstawionych w tabeli 1 obejmuje wszystkie aspekty procesu nauczania/uczenia się. Korzystając z tych wskazówek przy planowaniu lekcji, mamy pewność, że uwzględnione zostaną różne sfery - nie tylko w zakresie metod i treści, lecz również motywacji i nastawienia uczącego się. Nie zawsze jest jednak możliwe zaprojektowanie zajęć całkowicie dostępnych dla wszystkich, dlatego UDL dopuszcza w uzasadnionych przypadkach stosowanie dodatkowych pomocy, np. odpowiednio zaadaptowanych materiałów edukacyjnych lub technologii wspomagających (takich jak powiększalnik, wskaźnik ustny lub nagłowny, czytnik ekranu czy urządzenia umożliwiające komunikowanie się osobom ze złożonymi potrzebami komunikacyjnymi).

Warto w tym miejscu zwrócić uwagę, że uczeń ze specjalnymi potrzebami edukacyjnymi jest zwykle postrzegany przez pryzmat konkretnych zaburzeń, co nie zawsze pozwala na właściwą ocenę jego możliwości. Co oczywiste, istotne jest zapewnienie dziecku odpowiednich warunków i narzędzi, jednak metodyka pracy nie musi łączyć się bezpośrednio z rozpoznaną trudnością rozwojową. Kluczową rolę odgrywa właściwe zidentyfikowanie rzeczywistych możliwości i kompetencji ucznia, czyli określenie - w sposób funkcjonalny - posiadanych przez niego wiadomości i umiejętności, które powinny być rozwijane i stanowić bazę dla dalszego postępowania edukacyjnego. Każde proponowane w procesie nauczania zadanie składa się z wielu etapów, które należy pokonać, by uzyskać określony wynik (osiągnąć zamierzony cel). Każdy uczeń - zarówno rozwijający się prawidłowo, jak i mający rozpoznane specjalne potrzeby edukacyjne - może nie poradzić sobie z realizacją oczekiwanej czynności. Przystępując do uniwersalnego projektowania zajęć, należy zatem mieć świadomość, jakimi kompetencjami szczegółowymi musi dysponować uczeń, aby dane zadanie zostało zrealizowane. Na przykład rozwiązanie zadania z tekstem realizowanego na lekcji matematyki wymaga od ucznia m.in.:

$\rightarrow$ przeczytania i zrozumienia treści (a zatem posługiwania się słowami takimi jak „suma”, „razem”), 
$\rightarrow$ posiadania ukształtowanego pojęcia liczb w zakresie określonym w zadaniu,

$\rightarrow$ określenia danych potrzebnych do wykonania obliczeń,

$\rightarrow$ znajomości znaków matematycznych, które muszą zostać użyte przy zapisie działania,

$\rightarrow$ wiedzy o tym, że działanie matematyczne musi zostać zapisane według ściśle określonego wzorca (liczba - znak - liczba - znak - liczba, od strony lewej do prawej),

$\rightarrow$ umiejętności wykonania obliczenia,

$\rightarrow$ sformułowania i zapisania odpowiedzi na postawione pytanie.

U każdego ucznia mogą pojawić się trudności na jednym z etapów i nie muszą one wynikać z niepełnosprawności. Przy projektowaniu zadania ważne jest zatem poddanie analizie wszystkich składowych potrzebnych do jego wykonania. Wynikiem tego sposobu myślenia w zakresie projektowania może być stworzenie materiałów zaadaptowanych do potrzeb uczniów ze specjalnymi potrzebami edukacyjnymi, które różnią się od materiałów bazowych nie na poziomie treści programowych, lecz w obszarze metodyczno-technicznym. W wielu wypadkach nawet nieznaczna modyfikacja oryginału wystarcza, by uczeń ze specjalnymi potrzebami edukacyjnymi samodzielnie zrealizował oczekiwaną aktywność.

Przykładem materiałów, które mogą być wykorzystane przy projektowaniu i prowadzeniu zajęć w paradygmacie UDL, są adaptacje podręczników szkolnych wykonywane od 2014 r. przez Pracownię Lingwistyki Migowej na Wydziale Polonistyki Uniwersytetu Warszawskiego (por. Rutkowski, Mostowski 2017; 2018). Dotychczas do potrzeb edukacyjnych uczniów mających trudności w uczeniu się i (lub) komunikowaniu się, w tym niesłyszących, słabosłyszących, z niepełnosprawnością intelektualną, autyzmem i afazją, dostosowane zostały m.in. podręczniki do edukacji wczesnoszkolnej oraz do historii, matematyki, języka polskiego i przyrody dla klasy IV szkoły podstawowej, podręczniki do matematyki, biologii, geografii, historii i języka polskiego dla klasy V, podręczniki do wiedzy o społeczeństwie, biologii, chemii, fizyki, geografii, historii, matematyki i języka polskiego dla klasy VII, a także podręczniki do biologii, chemii, fizyki, geografii, historii, matematyki i języka polskiego dla klasy VIII. Pakiet materiałów do edukacji wczesnoszkolnej składa się z: 
$\rightarrow$ adaptacji oryginalnego podręcznika (przeredagowane treści poleceń, ilustracje zmodyfikowane pod kątem dostępności percepcyjnej),

$\rightarrow$ wersji multimedialnej (treści zaadaptowanej papierowej wersji podręcznika, uzupełnione o tłumaczenie na polski język migowy i znaki graficzne systemu PCS - picture communication symbols),

$\rightarrow$ zeszytu piktogramów (tabele z piktogramami PCS odpowiadającymi słownictwu poszczególnych lekcji oraz wybrane pytania i polecenia oddane tymi symbolami),

$\rightarrow$ poradnika dla nauczyciela (książka ze wskazówkami metodycznymi oraz dokładnym opisem dokonanych modyfikacji),

$\rightarrow$ zeszytu kart pracy (ćwiczenia utrwalające wiedzę i umiejętności określone w podstawie programowej),

$\rightarrow$ książek z serii „Język polski na plus” i „Nasz język polski” (ćwiczenia wspomagające nabywanie przez uczniów kompetencji komunikacyjnych w języku polskim).

W skład pakietu materiałów przygotowanych do każdego z podręczników do klas wyższych niż III wchodzą z kolei:

$\rightarrow$ zaadaptowane teksty dotyczące poszczególnych zagadnień przedmiotowych,

$\rightarrow$ ilustracje zmodyfikowane pod kątem dostępności percepcyjnej,

$\rightarrow$ tablice ze znakami graficznymi systemu PCS,

$\rightarrow$ filmy z tłumaczeniem na polski język migowy.

Szczegółowe informacje na temat zaadaptowanych tytułów można znaleźć na stronach internetowych Ministerstwa Edukacji Narodowej lub Ośrodka Rozwoju Edukacji ${ }^{3}$.

Opisane adaptacje były zaplanowane i przeprowadzone zgodnie z kluczowymi założeniami paradygmatu UDL. Każda treść została przedstawiona na kilka różnych sposobów (zaadaptowany tekst polski, tłumaczenie na polski język migowy, zapis znakami graficznymi systemu PCS) oraz w różnych formatach (wersja do druku, elektroniczna, multimedialna). Warstwa tekstowa była modyfikowana w celu 
eliminacji nadmiernej złożoności składniowej i trudności leksykalnych, ale z zachowaniem najistotniejszych informacji. Dodatkowo wybrane treści zostały opatrzone objaśnieniami lub ilustracjami pomocniczymi. Zmiany dotyczące warstwy graficznej miały na celu przede wszystkim dostosowanie możliwości jej odbioru do potrzeb psychofizycznych osób ze specjalnymi potrzebami edukacyjnymi. Zgodnie z wytycznymi UDL część modyfikacji dotyczyła zwiększenia zaangażowania uczniów - polecenia w formie bezosobowej zostały więc przekształcone w bezpośrednie zwroty do odbiorcy, zastosowano $w$ nich teksty ułatwiające przyznanie się do niewiedzy, a w przypadku trudniejszych zadań zaoferowana została możliwość wykonania ich prostszego wariantu. Dokładny opis przyjętych rozwiązań zamieszczono w towarzyszących poszczególnym podręcznikom książkach pomocniczych (swoistych poradnikach dla nauczyciela), zawierających materiał informacyjny dotyczący zalecanych sposobów korzystania z adaptacji (zob. m.in. Bajewska-Kołodziejak i in. 2014; 2017).

Zajęcia edukacyjne powinny przystawać do potrzeb wszystkich ich uczestników. Projektowanie takich lekcji bywa niezmiernie trudne. Im mniej homogeniczna grupa odbiorców i bardziej zróżnicowane potrzeby, tym więcej aspektów należy uwzględnić na etapie planowania. Jedną ze sprawdzonych metod tworzenia lekcji "dla wszystkich" jest stosowanie się do zasad projektowania uniwersalnego w nauczaniu (UDL). Wiele prostych wskazówek pozwala należycie dopracować każdy poziom procesu edukacyjnego. Standard ten funkcjonuje od prawie 30 lat, a liczne badania (por. m.in. Rao i in. 2014; Capp 2017) pokazują, że przynosi on korzyści zarówno osobom uczącym się, jak i nauczycielom. Z punktu widzenia uczniów ze specjalnymi potrzebami edukacyjnymi, planowanie zgodne z UDL będzie łatwiejsze do wprowadzenia dzięki wspomnianym bezpłatnym materiałom zaadaptowanym. Jest to z pewnością argument przemawiający za uwzględnieniem UDL w pracy pedagogicznej z uczniami ze specjalnymi potrzebami edukacyjnymi. 


\subsubsection{Ksztaltowanie pozytywnych relacji uczniów w edukacji włączającej}

Jacek Pyżalski

\section{Dziecko ze specjalnymi potrzebami w grupie rówieśniczej}

Funkcjonowanie dziecka ze specjalnymi potrzebami w grupie stanowi zwykle spore wyzwanie zarówno dla niego samego, jak i dla innych jej członków. Problemy dotyczące relacji rówieśniczych są od dawna dostrzegane i omawiane w literaturze światowej. Już w 2006 r. Chris Forlin pisał na temat szkół australijskich: „Jest ogólnie przyjętą prawdą, że zespoły klasowe są obecnie bardziej zróżnicowane niż kiedykolwiek wcześniej, a nauczyciele mogą się spodziewać, że będą musieli pracować z uczniami o szerokiej gamie potrzeb, nie tylko związanych z niepełnosprawnością, ale także z takimi, którzy mogą być wykluczani z wielu innych przyczyn" (Forlin 2006, s. 271). Wykluczenie, o którym tu mowa, wynika właśnie z postaw i działań rówieśników wobec dziecka ze specjalnymi potrzebami.

Piotr Plichta (2016) wskazuje, że w legislacji specjalne potrzeby w Polsce definiowane są bardzo szeroko (a do tego nie są nazywane wprost) i obejmują dzieci wymagające dostosowania rozwiązań wychowawczych i dydaktycznych. Odnoszą się one zatem do bardzo zróżnicowanych podgrup, czyli osób:

$\rightarrow$ niepełnosprawnych, niedostosowanych społecznie i zagrożonych niedostosowaniem społecznym: niesłyszących, słabosłyszących, niewidomych, słabowidzących, z niepełnosprawnością ruchową, w tym z afazją, z niepełnosprawnością intelektualną $w$ stopniu lekkim, umiarkowanym lub znacznym, $z$ autyzmem, w tym z zespołem Aspergera, i z niepełnosprawnościami sprzężonymi; 
$\rightarrow$ niedostosowanych społecznie lub zagrożonych niedostosowaniem społecznym;

$\rightarrow$ przejawiających szczególne uzdolnienia;

$\rightarrow$ doświadczających specyficznych trudności w uczeniu się;

$\rightarrow$ z zaburzeniami w komunikacji językowej;

$\rightarrow$ chorujących przewlekle;

$\rightarrow$ które przeżyły sytuacje kryzysowe lub traumatyczne;

$\rightarrow$ zmagających się z niepowodzeniami edukacyjnymi;

$\rightarrow$ które doświadczyły zaniedbań środowiskowych wynikających z sytuacji bytowej rodziny, sposobu spędzania czasu wolnego i kontaktów w najbliższym otoczeniu;

$\rightarrow$ z trudnościami adaptacyjnymi związanymi z różnicami kulturowymi lub ze zmianą środowiska edukacyjnego, w tym wynikającymi z wcześniejszego kształcenia za granicą.

Lista ta nie jest oczywiście wyczerpana, a specjalne potrzeby mogą dotyczyć także innych grup lub występować łącznie, co zawsze będzie przekładać się na indywidualną sytuację dziecka - jego wizerunek wśród rówieśników i relacje z kolegami. Osoby z wymienionych podgrup mają częściej problemy emocjonalne oraz obniżone umiejętności społeczne. Oczywiście ich głębokość oraz charakter mogą być zróżnicowane i w pewnym zakresie specyficzne dla określonej zbiorowości (np. Baker, Donelly 2001; Bejerot, Edgar, Humble 2011; Kaukiainen i in. 2002; Reiter, Lapidot-Lefler 2007).

W warunkach szkolnych mamy tu do czynienia z sytuacją zespołu klasowego, w którym pojawia się dziecko funkcjonujące - z różnych powodów - w sposób odmienny od rówieśników. Budzi to zwykle w innych dzieciach emocje, które mogą stanowić przeszkodę w budowaniu relacji oraz komunikacji (Forlin, Chambers 2003). To właśnie te emocje, a także słabe relacje i brak kompetencji w zakresie codziennej komunikacji z "innym" rówieśnikiem, są często $\mathrm{w}$ dłuższej perspektywie podstawą budowania negatywnych postaw wobec niego. Oczywiście postawy takie mogą być także obecne wcześniej i wynikać z oddziaływań szerszego środowiska, np. społecznych postaw wobec osób z niepełnosprawnością lub obcokrajowców. Nastawienia takie budują niekorzystny klimat, a także eskalują, przekładając się na codzienne postępowanie dzieci wobec "innego" rówieśnika.

Najgorsza sytuacja jest wtedy, gdy pojawia się przemoc rówieśnicza, której ofiarą pada dziecko ze specjalnymi potrzebami. Może mieć ona 
charakter fizyczny (bicie, niszczenie własności), werbalny (przezywanie, grożenie), elektroniczny (cyberprzemoc - przemoc przy użyciu technologii informacyjno-komunikacyjnych) oraz relacyjny (wykluczanie z grupy) (Pyżalski 2012). Wyniki badań światowych potwierdzają, że zaangażowanie dzieci ze specjalnymi potrzebami edukacyjnymi w proces nękania (bullying) jest wyższe (często kilkukrotnie) w porównaniu ze wskaźnikami u pozostałych rówieśników (por. Plichta 2016). Należy tu jednocześnie wskazać, że wbrew obiegowym opiniom dzieci ze specjalnymi potrzebami częściej stają się nie tylko ofiarami, ale także sprawcami przemocy rówieśniczej (ze względu choćby na często występujący niedostatek umiejętności społecznych), szczególnie wtedy, gdy nie mogą poradzić sobie z doświadczeniami wynikającymi z wcześniejszej wiktymizacji (Plichta, Olempska-Wysocka 2013; Plichta, Olempska-Wysocka 2014; Pyżalski 2012).

Warto zauważyć, że najpoważniejszy typ przemocy rówieśniczej - nękanie - przekłada się na poważne konsekwencje dotyczące wszystkich zaangażowanych, tj. sprawców, ofiar i świadków. Mamy z nim do czynienia, gdy wrogie działania mają charakter długotrwały, intencjonalny i wiążą się z przewagą sprawców. W sytuacji włączania do grupy dzieci o specjalnych potrzebach edukacyjnych ta ostatnia właściwość jest często automatycznie wpisana w sytuację. Nierównowaga sił może wynikać tu z mniejszej siły fizycznej ofiary, trudności poznawczych, trudności komunikacyjnych lub problemów w sferze emocjonalnej, które upośledzają zdolności obrony przed napastnikami (Pyżalski 2012). Niestety, konieczność dostosowania programów zapobiegających nękaniu do potrzeb dzieci ze specjalnymi potrzebami edukacyjnymi jest często ignorowana (Raskausas, Modell 2011).

Chcąc przeciwdziałać przemocy rówieśniczej, powinniśmy zatem szukać rozwiązań dotyczących wszystkich zaangażowanych osób - nie tylko sprawców i ofiar, ale także pozostałych uczniów, którzy bezpośrednio nie biorą udziału w tym procederze. Należy ponadto przyjąć, że najbardziej skuteczne są działania zapobiegawcze realizowane wtedy, kiedy jeszcze nie pojawiły się poważne oznaki przemocy wobec dziecka ze specjalnymi potrzebami edukacyjnymi. Im dłużej ta przemoc trwa, tym poważniejsze będą jej przejawy. Towarzyszyć im będzie także pogłębienie postaw wrogości wobec ofiary. Wszystko to sprawia, że nawet bardzo profesjonalne i dobrze przeprowadzone działania na dalszych etapach procesu nękania są często nieefektywne. 


\section{Jak ksztaltować pozytywne postawy uczniów wobec rówieśników ze specjalnymi potrzebami?}

Kiedy mówimy o kształtowaniu pozytywnych postaw i stwarzaniu warunków budowania korzystnych relacji z rówieśnikami ze specjalnymi potrzebami, w pierwszej kolejności mamy na uwadze zajęcia edukacyjne dla uczniów, które ich odpowiednio ukształtują i z których wyniosą odpowiednią wiedzę i pożądane umiejętności. Takie ujęcie ma jednak poważne ograniczenia, postawy bowiem formują się w wyniku codziennych doświadczeń, których oddziaływanie jest silniejsze niż nawet najlepiej zaplanowane szkolenia. W dalszej części tekstu przedstawiam istotne czynniki oddziaływania pedagogicznego i propozycje rozwiązań, które mają pozytywne przełożenie na relacje rówieśnicze z dzieckiem ze specjalnymi potrzebami edukacyjnymi (Krajewski, Hyde 2000).

\section{Nauczyciel jako wzór}

Dzieci poznają wiele rzeczy przez obserwację. Z tego względu bardzo istotna jest świadomość nauczyciela w zakresie jego rzeczywistych postaw i emocji związanych z pracą z podopiecznym ze specjalnymi potrzebami edukacyjnymi. Badania wskazują, że wielu pedagogów ma obawy w zakresie własnych kompetencji wychowawczych i dydaktycznych związanych z pracą z dziećmi z takimi potrzebami (Sudal-Malukiewicz 2001; Plichta, Olempska-Wysocka 2013; 2014). W takiej sytuacji postawa nauczyciela może przejawiać się behawioralnie w formie określonych reakcji emocjonalnych i działań związanych z zachowaniem ucznia ze specjalnymi potrzebami edukacyjnymi. Jeśli reakcje te naznaczone są silnymi emocjami lub bezradnością, albo kiedy nauczyciel odbiera zachowania ucznia jako przejawy wrogości, jego podopieczni mogą ulegać tym negatywnym emocjom. W rezultacie mogą wykazywać podobne zachowania i postawy wobec rówieśnika ze specjalnymi potrzebami edukacyjnymi. Ważne zatem, by nauczyciel uświadamiał sobie własne przeżycia oraz reakcje, a także żeby zdawał sobie sprawę, że nawet kiedy tego nie przewiduje, jest dla uczniów wzorem do naśladowania.

Pedagog, który rozumie funkcjonowanie dzieci ze specjalnymi potrzebami, wie, jak reagować w sytuacjach dla nich trudnych, jak je wspierać, jak tłumaczyć ich potrzeby pozostałym uczniom w taki sposób, by nie pojawiały się u nich negatywne emocje i postawy wobec 
rówieśników z tej grupy (Healy 2014). Prawidłowości tu przedstawione, choć dotyczą głównie nauczycieli ( $w$ tym tzw. wspierających), można odnieść w pewnym zakresie do wszystkich osób dorosłych w szkole, $w$ tym do personelu pomocniczego i administracyjnego. Ich działania i zachowania wobec dzieci z omawianej grupy także są obserwowane przez pozostałych uczniów.

Przy tego rodzaju zastrzeżeniach podstawową kwestią dla kształtowania postaw uczniów będzie postawa samego nauczyciela oraz jego przygotowanie do pracy z osobami ze specjalnymi potrzebami edukacyjnymi. Postawy nauczyciela i uczniów należy traktować jako naczynia połączone, trudno bowiem wyobrazić sobie, że pedagog skutecznie stosuje jakieś rozwiązania edukacyjne kształtujące podopiecznych, a jednocześnie sam prezentuje postawę negatywną. Przygotowanie praktyczne nauczyciela, związane przede wszystkim ze zrozumieniem i znajomością potrzeb osób ze specjalnymi potrzebami edukacyjnymi, należy traktować jako warunek sine qua non efektywnego formowania postaw innych uczniów wobec tej grupy. W uproszczeniu, ten obszar oddziaływań oznacza, że im częściej uczniowie będą obserwować pozytywne, pełne szacunku podejście swojego nauczyciela wobec dzieci ze specjalnymi potrzebami edukacyjnymi, tym większe będzie prawdopodobieństwo, że sami będą zachowywać się podobnie.

\section{Współpraca z rodzicami}

Inną grupą osób dorosłych, których postawy mogą mieć przełożenie na działania uczniów, są rodzice. Jeżeli uważają oni, że obecność osób ze specjalnymi potrzebami edukacyjnymi w zespołach klasowych obniża jakość dydaktyki lub stanowi niebezpieczeństwo dla pozostałych uczniów, może się to przełożyć na postawy ich dzieci. W wielu sytuacjach i w różny sposób rodzice komunikują tego typu podejście, nawet jeżeli nie bezpośrednio swoim dzieciom, to np. w ich obecności. Istotne jest zatem podejmowanie wyprzedzająco działań informacyjnych w sprawie specjalnych potrzeb uczniów w zespołach klasowych, ale także w zakresie tego, co robić, jeśli do rodziców dotrą wiadomości o pojawiających się sytuacjach nękania lub problemach interpersonalnych dotyczących relacji między dziećmi (Pyżalski 2018). Współpraca ta powinna dotyczyć także rodziców ucznia włączanego, choćby po to, by wszelkiego rodzaju problemy w interakcjach rówieśniczych diagnozować i rozwiązywać na wczesnym etapie. 
Rozpoczynając współpracę z rodzicami, pracownicy szkoły mogą przekazywać im informacje podczas zebrań klasowych, ale też z wykorzystaniem materiałów edukacyjnych dystrybuowanych w formie papierowej lub elektronicznej. Mogą to być:

1. Wskazówki dotyczące postępowania w sytuacji, gdy rodzice dowiedzą się o problemach w relacjach klasowych (bez względu na rolę, jaką odgrywa ich dziecko - sprawcy, ofiary czy świadka). Warto tu wyraźnie wskazać, że działania na wczesnym etapie, podejmowane we współpracy szkoły z rodzicami, przynoszą najlepsze efekty;

2. Kwestie dotyczące planowanych działań (także formalnych) inicjowanych przez szkołę w sytuacji, gdy pojawią się poważne przypadki przemocy rówieśniczej. Podejście takie jest transparentne i sprawia, że w razie zastosowania określonej wcześniej procedury jest ona traktowana jako naturalna konsekwencja, a nie arbitralne działanie placówki;

3. Informacje o potrzebach oraz ważnych aspektach funkcjonowania dziecka ze specjalnymi potrzebami i związanymi z tym działaniami (np. określone miejsca siedzenia w klasie, dostosowane sposoby sprawdzania wiedzy, specyficzne uwarunkowania komunikacyjne ucznia). Zanim tego typu wiadomości zostaną rozpowszechnione, muszą być ustalone i skonsultowane z rodzicami dziecka ze specjalnymi potrzebami edukacyjnymi.

\section{Organizacja sesji edukacyjnej}

\section{na temat specyfiki specjalnych potrzeb}

Wiele problemów związanych z akceptacją i nawiązywaniem przyjaźni z dziećmi ze specjalnymi potrzebami edukacyjnymi wynika z tego, że rówieśnicy nie rozumieją pewnych ograniczeń dotyczących tej grupy. Sprawdzonym rozwiązaniem, które może zapobiegać pojawianiu się tego typu kłopotów, są sesje edukacyjne dla rówieśników ucznia ze specjalnymi potrzebami edukacyjnymi. Ważne jest, by były one dostosowane do wieku uczestników i koncentrowały się na przekazywaniu konkretnych, praktycznych porad, dotyczących choćby zachowania się w codziennych sytuacjach (np. „Kiedy mówisz do kolegi, który słabo słyszy, musisz stanąć naprzeciwko niego, żeby cię widział"). Takie zasady, pozornie oczywiste, nie muszą być jasne dla większości dzieci, szczególnie w młodszych klasach szkoły podstawowej. 
Tego rodzaju zajęcia są często nazywane sesjami uświadamiania o niepełnosprawnościach (disability awareness sessions) (Raskauskas, Modell 2011). Oczywiście szkolenia mogą także dotyczyć uczniów, którzy znajdują się w innej sytuacji, np. dzieci z rodzin imigranckich. Najważniejsze, by były wprowadzane $w$ uzgodnieniu z dziećmi i ich rodzicami, a nie narzucane przez nauczyciela (Healy 2014). Niektórzy uczniowie mogą sami (przynajmniej w pewnym zakresie) poprowadzić tego typu sesje, np. dzieci, które przyjechały z innego kraju są w stanie opowiedzieć o swojej kulturze, zaprezentować powiązane z nią przedmioty.

Uczniowie mogą także określić swoje oczekiwaniach wobec innych. Ma to szczególne znaczenie podczas wprowadzania nowego ucznia do funkcjonującego zespołu klasowego - w takiej sytuacji ryzyko nieprzyjęcia go do grupy i prawdopodobieństwo odrzucenia są szczególnie wysokie, nawet w przypadku dzieci bez specjalnych potrzeb edukacyjnych.

Wdrażając te rozwiązania należy zawsze pamiętać, że dotyczą one kwestii drażliwych i budzą zainteresowanie, ale także wywołują silne emocje. Warunkami skutecznego działania w tym zakresie są: odpowiedni styl komunikacji nauczyciela podczas sesji dla dzieci, jego autentyczne zainteresowanie, obserwowanie reakcji dziecka ze specjalnymi potrzebami edukacyjnymi oraz innych uczniów, a także adekwatne reagowanie na nie. Opisywane $w$ tej części sesje edukacyjne mają bardzo duży potencjał edukacyjny, mogą jednak także bardzo zaszkodzić, gdy są realizowane nieumiejętnie.

\section{Stwarzanie okazji do codziennych interakcji i współpracy}

Kluczowym czynnikiem przyczyniającym się do budowania pozytywnych postaw wobec dzieci ze specjalnymi potrzebami edukacyjnymi jest stwarzanie przez nauczyciela okazji do interakcji i budowania więzi rówieśniczych. Chodzi tu głównie o działania, w ramach których wszyscy uczniowie mają okazję przebywać w grupie i wspólnie pracować, szczególnie z dziećmi ze specjalnymi potrzebami edukacyjnymi.

Wśród rozwiązań w tym zakresie wymienić można: przesadzanie uczniów w ławkach, by każdy z każdym mógł przez jakiś czas dzielić wspólną przestrzeń, tworzenie zespołów, w których dzieci wykonują określone zadania, lub organizowanie zabaw polegających na tym, że uczniowie robią coś na rzecz osoby, którą wylosowały. Te pozornie proste interakcje wymagają bardzo kompetentnego i refleksyjnego wdrażania. Nawet drobne elementy mogą zadecydować o tym, 
czy rozwiązania okażą się skuteczne. Na przykład, przesadzając uczniów w ławkach, trzeba pamiętać o określonych elementach metodycznych:

$\rightarrow$ procedurę wprowadza się w nowym zespole klasowym, nim uczniowie zdążą się przyzwyczaić do dzielenia ławki z jedną osobą - w takiej sytuacji zmiana miejsca w klasie traktowana jest jako naturalna i nie budzi kontrowersji;

$\rightarrow$ uczniowie muszą być powiadomieni, że z każdym kolegą i każdą koleżanką siedzą czasowo i że regularnie będą następowały zmiany;

$\rightarrow$ konfiguracje dotyczące tego, kto z kim siedzi, ustalane są losowo. W takiej sytuacji rzadziej dochodzi do konfliktów z uczniami niż wtedy, gdy decyzje w tym zakresie arbitralnie podejmuje nauczyciel;

$\rightarrow$ konieczne jest uwzględnianie ograniczeń w zastosowaniu tej metody w wypadku specjalnych potrzeb (np. niektórzy uczniowie ze spektrum autyzmu nie powinni uczestniczyć w zmianach miejsc, uczniowie z problemami sensorycznymi muszą siedzieć w pierwszych rzędach w sali);

$\rightarrow$ rodzice uczniów przed wprowadzeniem procedury przesadzania muszą być powiadomieni o takim rozwiązaniu i jego celach. Gdy ten aspekt zostanie zaniedbamy, mogą wystąpić konflikty z osobami, które tego typu działania mogą uznać za niepotrzebne i budzące negatywne emocje dzieci.

Trzeba jednak pamiętać, że aby rozwiązania mogły być skuteczne, muszą być wdrażane na odpowiednim etapie, czyli wtedy, gdy postawy wobec dziecka włączanego są neutralne. Nie można ich stosować w momencie, gdy uczeń stał się ofiarą nękania. Ich wprowadzenie w momencie, gdy problem odrzucenia lub przemocy już występuje, może jedynie pogorszyć sytuację ofiary. Oznacza to, że nauczyciel pracujący w edukacji włączającej musi być proaktywny i podejmować stosowne kroki, zanim pojawią się kłopoty związane z relacjami rówieśniczymi.

\section{Przygotowanie ucznia ze specjalnymi potrzebami edukacyjnymi}

Na postawy klasy wpływają także działania podejmowane przez samego ucznia ze specjalnymi potrzebami edukacyjnymi (lub jego bierność). W wielu sytuacjach pomocne mogą się okazać działania edukacyjne lub doradcze wspierające takie dziecko. Efektem tego wsparcia 
może być zwiększenie jego kompetencji komunikacyjnych, co umożliwi mu lepszy kontakt z rówieśnikami. Tego rodzaju oddziaływania mogą się również przyczynić do zredukowania zachowań, które są przez rówieśników odbierane jako prowokacyjne czy agresywne - praca $w$ tym zakresie może dotyczyć np. korygowania sposobu współpracy dziecka z rówieśnikami (np. podczas zapraszania do zabawy), jego reakcji na zaczepki lub konflikty, a także zachęcenia go do poszukiwania wsparcia dorosłych, gdy nie umie samodzielnie rozwiązać pojawiających się problemów (przy założeniu, że pomagają oni tylko w takim stopniu, w jakim jest to niezbędne).

\section{Podsumowanie}

Na zakończenie rozważań dotyczących kształtowania postaw uczniów wobec rówieśników ze specjalnymi potrzebami, warto wskazać, że proponowane rozwiązania są zgodne z kluczowymi założeniami dobrych praktyk w zakresie inkluzji.

Tim Loreman (2007) w tekście Seven pillar of support for inclusive education (Siedem filarów wsparcia edukacji włączającej) wskazuje, że najistotniejszymi elementami są:

1. Budowanie pozytywnych postaw nauczycielskich wobec inkluzji, a przede wszystkim wobec dzieci włączanych.

2. Możliwości organizacyjne w szkołach, związane z elastyczną realizacją programu i zadań dydaktycznych (w kontekście specjalnych potrzeb dzieci i ich chęci osiągnięcia sukcesu edukacyjnego).

3. Aktywizacja środowiska zewnętrznego szkoły (głównie rodziców) na rzecz wspierania inkluzji.

Zaproponowane rozwiązania stanowią kluczowy element inkluzji, bez którego cały proces może okazać się porażką. 



\subsubsection{Ocenianie ksztaltujące \\ - ocenianie wspierające \\ uczniów ze specjalnymi \\ potrzebami edukacyjnymi}

Urszula Skrzypczak

Podejście do oceniania kształtującego (OK) zmienia się i ewoluuje w ostatnich latach. Nauczyciele uczą się korzystać z tej strategii - poznają ją, stosują i wymieniają się doświadczeniami, by pełniej wspierać wszystkich uczniów, w tym tych ze specjalnymi potrzebami edukacyjnymi.

Zmieniła się również definicja oceniania kształtującego, które - według Danuty Sterny (2016) - „polega na pozyskiwaniu przez nauczyciela i ucznia w trakcie nauczania informacji, które pozwolą rozpoznać, jak przebiega proces uczenia się, aby:

$\rightarrow$ nauczyciel modyfikował dalsze nauczanie,

$\rightarrow$ uczeń otrzymywał informację zwrotną pomagającą mu się uczyć".

Komitet Psychologii PAN odejście od stopni na rzecz oceny kształtującej w ocenianiu bieżącym uzasadnił następująco: „Ocena ze strony nauczyciela odgrywa swoją formatywną rolę, czyli jest prorozwojowa, tylko wtedy, gdy dostarcza dziecku informacji pomagających mu się uczyć, a więc umożliwia: (1) uświadomienie sobie, co robi dobrze, a co źle, (2) zrozumienie istoty popełnianych błędów, (3) wskazuje drogi poprawy, ale przede wszystkim, (4) wskazuje, w czym dziecko jest kompetentne, co osiągnęło dzięki swemu wysiłkowi. Taki sposób oceniania wzmacnia wytrwałość uczącego się dziecka, buduje jego poczucie sprawstwa, w tym odpowiedzialności za własne działania, a w efekcie kształtuje zdolność samoregulacji, tak ważną w kolejnych etapach kształcenia oraz w życiu. 
Ocena według stopni, szczególnie gdy jest jedyną albo najczęstszą formą oceniania, nie niesie za sobą prorozwojowej informacji zwrotnej dla dziecka, w głównej mierze służy porównywaniu dzieci ze sobą. We wczesnym etapie edukacji, kiedy dzieci dopiero opanowują różne strategie uczenia się, nie pomaga im $w$ tym procesie, a w przypadku dzieci natrafiających na różnorodne trudności w uczeniu się może hamować ich motywację i być wręcz źródłem ich bezradności.

Ocenianie opisowe może początkowo być uciążliwe dla nauczyciela, ale niesie ze sobą cenne dla niego informacje. Pomaga mu w dobieraniu trafnych i potrzebnych dla dzieci metod wspomagania ich rozwoju, szczególnie w zakresie strategii uczenia się, metod pomocy w sytuacjach, gdy dzieci mają trudności w uczeniu się, a także metod rozwijania ich specjalnych zdolności i talentów"1.

Strategie oceniania kształtującego można wykorzystać w procesie uczenia się i nauczania uczniów ze specjalnymi potrzebami edukacyjnymi na kilka sposobów.

\section{Strategia I: Określanie i wyjaśnianie uczniom celów uczenia się i kryteriów sukcesu (Sterna 2014)}

Określenie celu to podstawowe działanie rozpoczynające proces uczenia się. Uświadamia ono nauczycielowi, a także uczniowi, po co podejmowany jest wysiłek związany ze zdobyciem konkretnej wiedzy i umiejętności, do czego te elementy przydadzą się w dalszej edukacji, w życiu codziennym lub w praktyce. Już na tym etapie ważne jest, by nauczyciel wspomagający wiedział, czy cel lekcji dla uczniów ze specjalnymi potrzebami edukacyjnymi będzie taki sam, jak dla innych, czy też nastąpi modyfikacja w tym zakresie. Warto zadać sobie proste pytanie: „Dlaczego tego nauczam?”. Uczniowie lepiej przyswajają wiedzę, jeżeli wiedzą, po co to robią. Doświadczeni pedagodzy podejmują działania związane z określaniem celów lekcji (w języku zrozumiałym dla uczniów), są też gotowi do negocjacji w tym zakresie. Dobrze sformułowany cel rozpoczyna uczenie się, a końcowe sprawdzenie stanu jego realizacji „zamyka” proces edukacyjny w odniesieniu do lekcji, działu czy podstawy programowej. Przeprowadzenie podsumowania 
jest niezwykle istotne, ponieważ dostarcza nauczycielowi bezcennych informacji.

Określanie kryteriów sukcesu i wyjaśnianie ich uczniom porządkuje proces uczenia się. "NaCoBeZU" ("Na co będziemy zwracać uwagę") to warunki, które precyzują, jaką wiedzę uczeń ma zdobyć. Jest tutaj miejsce na wprowadzanie przez nauczyciela modyfikacji (zarówno jakościowych, jak i ilościowych), w związku ze specjalnymi potrzebami edukacyjnymi konkretnych podopiecznych. Trzeba pamiętać o wprowadzanych zmianach i koniecznie uwzględniać je, przygotowując kryteria sukcesu dla uczniów z różnymi deficytami, np. w sprawdzianie podsumowującym dany dział czy w pracy domowej. Podobnie jak cele, powinny być one czytelne dla uczniów - umożliwiają bowiem monitorowanie procesu edukacyjnego, dokonanie samooceny przez każde dziecko, planowanie dalszych działań, następnych lekcji. Uczniowie młodsi i ze specjalnymi potrzebami edukacyjnymi często korzystają z "nacobezowników" zawierających stałe kryteria sukcesu, np. dotyczące zasad pisania konkretnych form wypowiedzi, czytania, rozwiązywania zadań tekstowych, wykonywania prac technicznych, plastycznych. Kryteria powinny być określane do każdej pracy wykonywanej przez uczniów. Ambitnym wyzwaniem jest ustalanie ich z uczniami i negocjowanie z nimi kwestii ilościowych.

\section{Strategia II: Organizowanie w klasie dyskusji, zadawanie pytań i realizowanie zadań dających informacje, czy i jak uczniowie się uczą (Sterna 2014)}

Stosowanie tej strategii ma szczególne znaczenie w pracy z uczniami ze specjalnymi potrzebami edukacyjnymi. Zakłada ona ciągły dialog nauczyciela z podopiecznymi, dotyczący tego, co już zrozumieli i czemu należy poświęcić więcej czasu. Wiąże się ze stałym monitorowaniem procesu uczenia się, a także z poznaniem i określeniem „strefy najbliższego rozwoju" ucznia. W dialogu następuje rozpoznanie jego indywidualnych możliwości i dostosowanie odpowiednich do nich zadań, poleceń oraz kolejnych działań edukacyjnych. Niezbędne są tu umiejętności zadawania pytań i uważnego, aktywnego słuchania. Strategia zakłada aktywność zarówno po stronie nauczyciela, jak i ucznia. Opiera się na budowaniu relacji związanych z poczuciem bezpieczeństwa i stwarzaniu warunków nieskrępowanego wyrażania swoich odczuć i opinii. 
W ocenianiu kształtującym ważne są podstawowe zalecenia związane z:

$\rightarrow$ oczekiwaniem na odpowiedź (co najmniej pięć sekund),

$\rightarrow$ poprzedzaniem odpowiedzi na postawione pytania rozmową w bezpiecznych parach,

$\rightarrow$ stosowaniem zasady niepodnoszenia rąk lub losowania patyczków,

$\rightarrow$ prawem do błędów i wykorzystywaniem ich w procesie uczenia się,

$\rightarrow$ wykorzystaniem pytań otwartych.

Dzięki tej strategii nauczyciel w dowolnym momencie lekcji wie, na jakim etapie procesu edukacyjnego znajduje się uczeń, a w związku z tym może dostosować przekazywanie wiedzy do potrzeb ucznia (określonych na podstawie informacji uzyskanych w trakcie rozmowy) oraz stosować pytania i techniki pomagające w nauce.

\section{Strategia III: Udzielanie uczniom informacji zwrotnych, które umożliwiają im czynienie postępów (Sterna 2014)}

Informacja zwrotna wiąże się bezpośrednio z ustalonymi wcześniej i znanymi uczniowi kryteriami sukcesu. Pełna składa się z czterech elementów i jest kluczowa w procesie uczenia się:

1. Co uczeń zrobił dobrze?

Docenienie prawidłowo wykonanej pracy jest podstawą budowania motywacji do dalszego uczenia się. Daje uczniowi poczucie sprawstwa, umożliwia doskonalenie samokontroli oraz realizacji zadań zgodnie z wymaganymi procedurami. To po tym etapie każda osoba, a szczególnie ze specjalnymi potrzebami edukacyjnymi, jest gotowa przyjąć odpowiedzi na drugie i trzecie pytanie postawione w informacji zwrotnej.

2. Co należy poprawić?

3. Jak należy poprawić?

Wskazanie obszarów, które należy zmienić, nie wypełnia wymagań dobrej informacji zwrotnej. Niezbędna do dalszego rozwoju jest wskazówka, a czasami szczegółowa procedura, dotycząca sposobu poprawienia błędu. Procedura może być wsparciem dla ucznia, który potrzebuje dodatkowych informacji i precyzyjnych poleceń. Może ona pełnić funkcję pomocniczą wobec kryteriów, precyzyjnie ukierunkowując działania ucznia, być drogowskazem do sukcesu, nie zawężając wcześniej ustalonych kryteriów. Wskazując obszary do poprawy, 
nie należy wychodzić poza wcześniej ustalone warunki sukcesu, dostosowane do możliwości ucznia ze specjalnymi potrzebami edukacyjnymi.

W tej części opisu ważna jest umiejętność nauczyciela związana z udzielaniem informacji zwrotnej w języku faktów. Opisową wiadomość dla ucznia, który popełnia dużo błędów i ma problemy z realizacją ustalonego „NaCoBeZU”, można zakończyć na trzecim elemencie.

Kolejny jest bardzo ważny dla osób, które przejawiają kierunkowe zdolności, pasje w jakiejś dziedzinie, uzdolnienia, ponadprzeciętne zainteresowanie danym przedmiotem. Udzielenie odpowiedzi na postawione poniżej pytanie jest dla ucznia istotne $z$ punktu widzenia jego przyszłych działań.

4. Jak uczeń ma się dalej rozwijać?

W tej części nauczyciel stawia przed podopiecznymi wyzwania, zachęca ich do bardziej intensywnej pracy, stara się wpływać na rozwój ich mocnych stron. Tu jest miejsce na „podniesienie poprzeczki". Ta część informacji zwrotnej bywa bardzo osobista. Od niej może zależeć, czy uczeń nabierze chęci do podjęcia większego wysiłku i do rozwoju. Warto zaproponować mu więcej niż jedno wskazanie, zachęcić do wyboru lub poszukania możliwości.

Ten etap można także wykorzystać w pracy z "uczniem podwójnie wyjątkowym". To swoiste wyzwanie dla nauczyciela wspomagającego i nauczyciela przedmiotu, którzy w duecie ustalają wsparcie dla podopiecznego ze specjalnymi potrzebami edukacyjnymi.

Rzetelna, pełna, wyczerpująca informacja zwrotna jest szczególnie ważna przy pierwszym sprawdzaniu tego, jak uczniowie opanowali np. umiejętność poprawnego pisania (zaproszenia, opisu, charakterystyki), rozwiązywania zadań tekstowych, wykonania prezentacji, rysowania bryły przestrzennej czy skoku przez kozła. Daje wyjątkową okazję do uczenia się na własnych błędach, jest również wzorem dokonywania oceny koleżeńskiej i uczy argumentowania.

Informacja zwrotna przekazywana indywidualnie może znacznie ułatwić budowanie prawidłowych relacji między uczniem ze specjalnymi potrzebami edukacyjnymi a nauczycielami.

\section{Strategia IV: Umożliwianie uczniom korzystania z siebie nawzajem jako zasobów edukacyjnych (Sterna 2014)}

Strategia IV zakłada, że dzieci lepiej się uczą, jeśli korzystają z wiedzy i umiejętności swoich koleżanek i kolegów. Dla osób ze specjalnymi 
potrzebami edukacyjnymi ta metoda jest szczególnie ważna, zarówno w obszarze edukacji, jak i rozwoju społecznego (często bardzo nieharmonijnego, dysfunkcyjnego).

Opiera się ona na założeniu, że społeczny aspekt uczenia się jest bardzo ważny - dlatego proces edukacyjny jest tak organizowany, by uczniowie często mogli pracować w parach lub w większych grupach. Koordynowanie pracy zespołów wymaga kolejnych umiejętności i dobrego rozpoznania indywidualnych potrzeb uczniów. To w ramach tej strategii rozwija się kompetencje kluczowe (skuteczne komunikowanie się, praca w zespołach zadaniowych, realizacja prezentacji, aktywne słuchanie), a także uczy dokonywania oceny koleżeńskiej. Dzięki niej uczniowie mogą w bezpiecznym otoczeniu rozwijać swoje kompetencje społeczne, uczyć się współdziałania. To doświadczenie, które - bez wątpienia - przyda im się w dalszym, dorosłym życiu.

\section{Strategia V: Wspomaganie uczniów, by stali się odpowiedzialnymi autorami procesu swojego uczenia się (Sterna 2014)}

Wprowadzenie tej strategii przysparza nauczycielom najwięcej trudności. Wiąże się ona nierozerwalnie z wiarą ucznia w jego możliwości oraz z jego zainteresowaniem działaniami z zakresu świadomego uczenia się. Uczniowie zdolni lub „podwójnie wyjątkowi” łatwiej podejmują to ryzyko, co wynika bezpośrednio z ich wysokiego poczucia własnej wartości i ze świadomości własnych mocnych stron.

Zastosowanie strategii $V$ dla innych uczniów ze specjalnymi potrzebami edukacyjnymi jest możliwe, wymaga jednak ostrożnego wprowadzania i uświadomienia sobie, że wcześniej omawiane strategie również wspierają odpowiedzialność i samosterowność uczniów. Świadomi nauczyciele motywują uczniów do dokonywania wyborów, najczęściej w zakresie pracy domowej (np. jedna lub dwie w semestrze, które należy przygotować) lub ilości materiału (np. selekcja spośród wielu przykładów reakcji chemicznych czy działań arytmetycznych). Na tym etapie zachęca się też uczniów do dochodzenia do własnych rozwiązań i sposobów ich prezentacji.

Strategii V sprzyja prowadzenie przez uczniów „OK-zeszytu”, zawierającego samodzielne notatki, zapisy, rysunki, skojarzenia, symbole, pomagające im uczyć się i rozwijać. Inną techniką związaną z planowaniem własnego rozwoju jest portfolio uczniowskie, umożliwiają- 
ce drobiazgowe planowanie działań, konsekwentną realizację planu, poprawną samoocenę i weryfikowanie postawionych celów. Stosując tę technikę, uczeń może sięgać wstecz i świadomie planować swoją naukę i przyszłość. Strategię $V$ można podsumować słowami: „Uczniowie, którzy sami dążą do zdobywania wiedzy, mają większą motywację, więcej się uczą i lepiej rozwijają umiejętności metapoznawcze niż uczniowie, którzy jedynie wypełniają polecenia nauczycieli. A co nie mniej ważne - na pewno są w stanie powiedzieć, czego się nauczyli" (Moss, Brookhart 2014).

Wszystkie strategie oceniania kształtującego mają funkcję wspierającą nauczanie i uczenie się grupy ze specjalnymi potrzebami edukacyjnymi. Usprawniają procesy edukacyjne i rozwój umiejętności społecznych, uczą samooceny i brania odpowiedzialności za własny rozwój. Wszystkie działania z nimi związane muszą uwzględniać indywidualne potrzeby i wymagania, ale też $w$ naturalny sposób poszerzać możliwości wszystkich uczniów, w tym tych ze specjalnymi potrzebami edukacyjnymi. 



\subsubsection{Start w dorosłość}

- uwarunkowania, wyznaczniki

oraz proces przejścia z edukacji

do rynku pracy uczniów

ze specjalnymi potrzebami

edukacyjnymi

Wojciech Otrębski

Dowiadując się o tym, że zostaliśmy rodzicami, odczuwamy ogromną radość $\mathrm{i}$ jednocześnie uświadamiamy sobie, że nowy, mały człowiek zaczyna właśnie swoją indywidualną, długą drogę życia. Znaczą ją kolejne etapy rozwojowe. Każdy jest ważny, konieczny i ma określony przebieg, a kompetencje i doświadczenia nabyte w jednym z nich potrzebne są do właściwej realizacji następnych. Pokonywanie kolejnych etapów to - za E.H. Eriksonem (1968; 1997) - "tranzycje rozwojowe". Wyjątkowe znaczenie w rozwoju każdego człowieka ma wchodzenie (tranzycja) w dorosłość, czyli w ten okres, który trwa najdłużej i dla niektórych osób jest najtrudniejszy (Brzezińska 2000; Kowalik 2000; Obuchowska 2000; Trempała 2000). Młodzi niepełnosprawni są jedną z grup społecznych, w której jest wiele osób doświadczających dodatkowych trudności we wchodzeniu w dorosłe życie (Rzedzicka, Kobylańska 2003; Baker, Vaks 2013; Marshall, Goessling, Young, Wozniak-Molnar 2018).

Dorosłość można opisywać i analizować z różnych perspektyw. Jako ostatni z etapów rozwojowych utożsamiana jest z pojęciem „dojrzałości rozwojowej", czyli najbardziej pożądanym stanem, niezbędnym do prawidłowego funkcjonowania człowieka w społeczeństwie (Kowalik 2003). Najczęściej definiowana jest przez wymienianie zadań rozwojowych, jakie przynależą do tego etapu, lub przez podawanie społecznie 
oczekiwanych charakterystyk (cech) osób dojrzałych, odróżniających ją od tych, które tego etapu rozwoju jeszcze nie osiągnęły.

Maria Tyszkowa (1997, s. 952-953), odwołując się do opracowania Roberta J. Havighursta, wyjaśnia, że główne zadania rozwojowe człowieka dorosłego to:

$\rightarrow$ w okresie wczesnej dorosłości: rozpoczęcie pracy zawodowej, wybór stałego partnera i nabycie umiejętności życia w stałym związku, zrodzenie potomstwa, opieka nad dziećmi i wychowanie ich, prowadzenie domu;

$\rightarrow$ w okresie średniej dorosłości: osiągnięcie i utrzymanie satysfakcjonującej kariery zawodowej, wspomaganie rozwoju dorastających dzieci i pomaganie im w rozpoczynaniu samodzielnego życia, opieka nad starzejącymi się rodzicami, osiągnięcie zamierzonego standardu egzystencji;

$\rightarrow$ W okresie późnej dorosłości: przystosowanie do emerytury, do zmian w budżecie, do większej ilości wolnego czasu.

Stanisław Kowalik (2003, s. 65-66) interpretuje realizację zadań rozwojowych poprzedzających etap dorosłości jako gromadzenie przez jednostkę zasobów i tym samym "dążenie do powiększania liczby szans na aktywne życie $w$ dorosłości. [...] Powodzenie $w$ dochodzeniu do dorosłości może być rozumiane jako kumulowanie się: a) poziomu osiągniętej dojrzałości organizmu; b) coraz lepszych możliwości poznania siebie i własnego otoczenia; c) zdobywanych systematycznie doświadczeń związanych z pełnieniem wybranych ról rodzinnych, zawodowych i innych ważnych społecznie. Sama dorosłość oznacza zasadniczo osiągnięcie celu własnego rozwoju, zaczyna się wówczas faza stabilizacji życiowej, polegająca na wzbogaceniu otoczenia społecznego o wytwory własnej działalności o wartości adekwatnej do osiągniętego poziomu rozwojowego". Ten etap życia autor rozumie jako "konsumowanie rezultatów własnego, wcześniejszego rozwoju" (rys. 1). 
Rysunek 1. Wymiary uzyskiwania dorosłości w procesie rozwoju

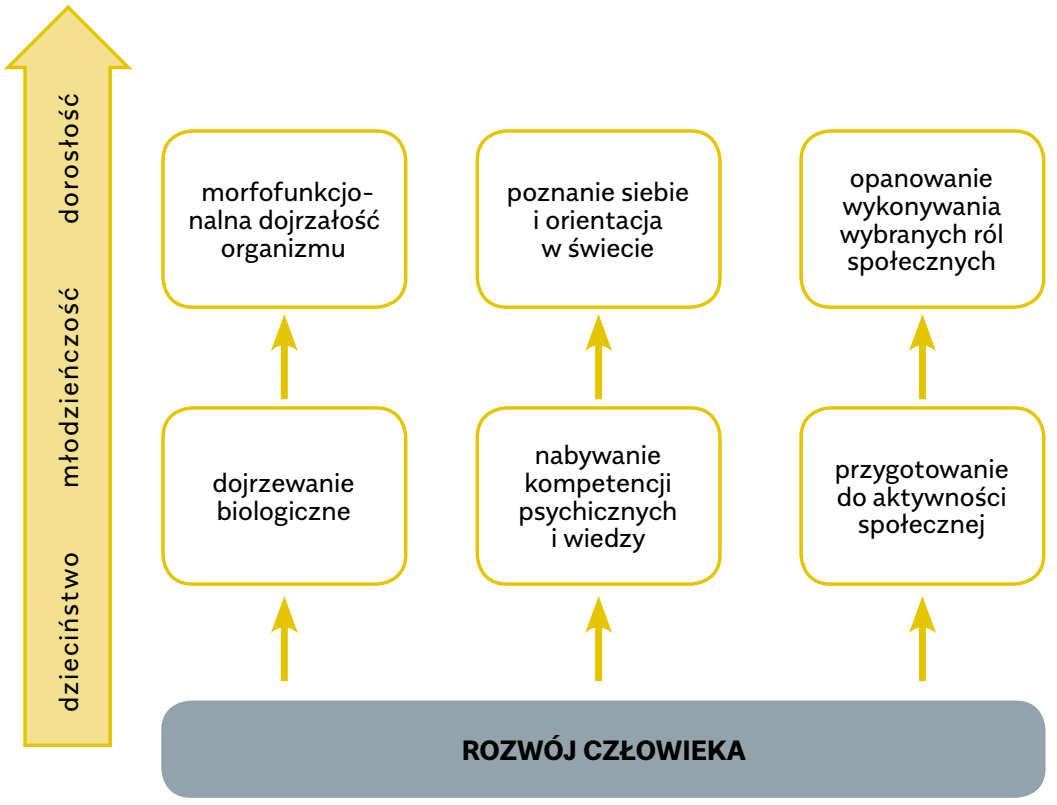

Źródło: Opracowanie własne na podstawie: Kowalik 2003, s. 66.

Z kolei Krystyna D. Rzedzicka (2003, s. 97), która przeprowadziła badania nad posiadanymi przez ludzi koncepcjami własnej dorosłości, wyróżniła cztery kategorie opisu tego etapu:

$\rightarrow$ jako dojrzałość,

$\rightarrow$ jako dojrzewanie (proces stawania się),

$\rightarrow$ jako status społeczny,

$\rightarrow$ jako status metrykalny.

Analizując uzyskane wypowiedzi, zauważyła też, że wspomniane koncepcje dorosłości nie zawsze pojawiają się u badanych w czystej postaci. Czasami mówią o nich łącznie (traktując je jako równorzędne), a innym razem jako wewnętrze i zewnętrzne oznaki dojrzałości. $U$ jednej $\mathrm{z}$ badanych osób pojawiało się kilka koncepcji dorosłości naraz.

Podsumowując stan wiedzy w zakresie opisywania zjawiska dorosłości człowieka, warto przywołać spostrzeżenia jakie poczyniła Antonina 
Ostrowska (2003, s. 53) w refleksjach dotyczących dyspozycji i umiejętności społecznych, które powinny posiadać osoby niepełnosprawne, wchodzące w dorosłość:

$\rightarrow$ zdolność identyfikowania celów, które się chce osiągnąć;

$\rightarrow$ umiejętność dokonywania realistycznej oceny pojawiających się szans i trudności;

$\rightarrow$ otwartość na nowe doświadczenia, gotowość do uczenia się i zdobywania nowych kwalifikacji;

$\rightarrow$ znajomość i rozumienie różnych (formalnych i nieformalnych) systemów społecznych istniejących w społeczeństwie, zdolność do poruszania się w nich i korzystania z możliwości, które oferują;

$\rightarrow$ umiejętność pozyskiwania wszelkiego rodzaju informacji stanowiących klucz do sukcesu we wszystkich nowoczesnych społeczeństwach oraz przetworzenia tych informacji na konkretne działania;

$\rightarrow$ zdolność do dostrzegania i wykorzystywania alternatywnych możliwości prowadzących do osiągania wyznaczonych celów i uruchamianie różnego rodzaju zasobów - osobistych, rodzinnych, przyjacielskich, sąsiedzkich, tkwiących w organizacjach, społecznościach lokalnych, parafiach i innych - istniejących niezależnie od struktur państwowych.

We wszystkich wspominanych opisach dorosłości ważnym jej wyznacznikiem jest zadanie rozwojowe dotyczące podjęcia i utrzymania zatrudnienia, realizacji własnej kariery oraz odgrywania ról zawodowych. Przywołując ponownie koncepcję tranzycji rozwojowych, zauważamy współwystąpienie momentu wchodzenia w dorosłość z przechodzeniem młodzieży ze szkoły do rynku pracy. Nałożenie się w czasie tych dwóch tranzycji rozwojowych powoduje, że ten etap jest uważany za najtrudniejszy w życiu każdego człowieka. Jak wyjaśnia Bohdan Rożnowski (2009, s. 35), "centralnym elementem wejścia w dorosłość jest przejście od roli receptywnej, podporządkowanej, niesamodzielnej, charakterystycznej dla systemu edukacji - roli dziecka i ucznia - do wejścia w świat pracy, związany w powszechnym przekonaniu z samodzielnością, odpowiedzialnością, dawaniem i wytwarzaniem (rolą osoby dorosłej, pracownika). Moment ten nazywany jest «tranzycją ze świata edukacji do świata pracy»". Opuszczenie systemu edukacji, czyli bezpiecznego 
azylu i miejsca dobrze znanego, jest tak bardzo trudnym doświadczeniem dla osób młodych, że starają się one ten moment jak najbardziej opóźnić. Zauważono w związku z tym pojawianie się kolejnego okresu rozwojowego na styku wieku młodzieńczego i dorosłości - „wyłaniającą się dorosłość" (emerging adulthood). Obejmuje on przedział od 17. do 25. roku życia (Bańka 2005).

Przejście z edukacji i skuteczne odnalezienie się młodego dorosłego na rynku pracy, podobnie jak dobra realizacja przez niego okresu dorosłości, ma swoje uwarunkowania przede wszystkim w tym, jak przebiegały wcześniejsze etapy rozwojowe. Odwołując się do ekonomicznej teorii filtra, można stwierdzić, że o tym, jak ktoś ostatecznie odnajduje się na rynku pracy i jaką zajmuje tam pozycję, decyduje przede wszystkim kapitał ludzki zgromadzony w trakcie dotychczasowego rozwoju. Pod tym pojęciem rozumie się wiedzę, zdrowie i zdolności człowieka, przyczyniające się do jego produktywności. Osoby z wyższym kapitałem (zasobami) są bardziej produktywne, a co z tego wynika - bardziej poszukiwane i lepiej nagradzane przez pracodawców (Kopycińska 2003; Marttinen, Dietrich, Salmela-Aro 2018). Efektywne przejście z systemu edukacji do rynku pracy jest odbierane jako funkcja kapitału ludzkiego zgromadzonego podczas nauki. Samo świadectwo ukończenia tej czy innej szkoły nie jest wystarczające, konieczne jest posiadanie wrodzonych predyspozycji, uzdolnień, chęci do uczenia się, a także ich rozwój i doskonalenie w czasie nauki szkolnej (Rożnowski 2009).

Obecnie w większości rozwiniętych krajów świata nie kwestionuje się potrzeby instytucjonalnego wspierania procesu tranzycji młodzieży z edukacji do rynku pracy. Od ponad pięciu dekad teoretycy i praktycy poszukują najlepszego sposobu realizacji tego etapu. Wśród licznych idei za najbardziej wartościową uznawana jest koncepcja strategiczna. Przyjmuje się w niej, że proces tranzycji realizowany jest w trakcie podejmowania kolejnych decyzji podmiotu i wynika z jego intencjonalnego wyboru, którego celem jest znalezienie pracy. Biorąc pod uwagę sytuację na rynku pracy i zachowania konkurentów, on sam wybiera najbardziej dla siebie korzystny sposób działania (Tchibozo 2002 [za: Rożnowski 2009]). Zwraca się też uwagę na konieczność uwzględnienia różnic kulturowych w realizacji tego procesu (Achola 2018).

Dotychczasowe wyjaśnienia koncentrowały się na stanie wiedzy i wynikach badań dotyczących ogólnie młodych ludzi będących w pro- 
cesie tranzycji z edukacji do rynku pracy. Warto jednak przedstawić ich uzupełnienie, które wydaje się konieczne, jeżeli proces tranzycji ma dotyczyć osób z różnego rodzajami niepełnosprawności.

Najogólniej mówiąc, niepełnosprawność może być orzeczona w sytuacji, kiedy u danej osoby zauważamy zmiany w zakresie jej codziennego funkcjonowania, najczęściej spowodowane nieprawidłowościami w funkcjonowaniu organizmu. Ograniczenia funkcjonalne zazwyczaj dotyczą obszarów: samoobsługi, różnych aktywności, właściwego odgrywania ról (w tym zawodowej) oraz uczestnictwa w życiu społecznym (w tym edukacji i aktywności zawodowej). W zależności od przyczyny, niepełnosprawność może dotyczyć ograniczeń motorycznych (mała i duża motoryka), sensorycznych (wzrok, słuch), umysłowych, psychicznych. Nierzadko współwystępuje kilka przyczyn i wówczas mówimy o niepełnosprawności sprzężonej (ICF 2012; Otrębski 2018). Orzeczony stan niepełnosprawności i związane z tym ograniczenia funkcjonalne dziecka/ucznia nierzadko generują specjalne potrzeby edukacyjne (SPE). Uczeń ze SPE stanowi wyzwanie dla systemu edukacji, odkąd się w nim pojawi. Wymaga on dopasowania ścieżki edukacji do jego potrzeb i możliwości, jak również szczególnie dobrze zaplanowanego wsparcia w procesie przejście z edukacji do rynku pracy.

Sukcesy w edukacji zawodowej młodzieży ze SPE, czyli zatrudnienie absolwenta, utrzymanie się przez niego w pracy i awans zawodowy, są osiągane w państwach realizujących model tranzycji (przejścia) z edukacji do zatrudnienia, głównie do rynku pracy. Realizacja modelu to specyficzna organizacja działań, która wymusza na placówce prowadzącej kształcenie zawodowe zbudowanie lokalnej koalicji z partnerami (rodzice, opiekunowie, instytucje rynku pracy i pomocy społecznej; organizacje pozarządowe). Pozwala to wspierać ucznia jeszcze przed zakończeniem edukacji, a następnie przez pierwsze lata pracy i jednocześnie dorosłego, samodzielnego życia (Kelley, Coc 2015; Timmons, Fesko, Zalewska 2015; Marshall i in. 2018).

Przedstawiając model tranzycji i opis jego wykorzystania w ułatwieniu młodym osobom z niepełnosprawnością wejścia w dorosłość, można się odwołać dziś głównie do doświadczeń zagranicznych, sięgających lat 80. minionego stulecia. Jeden z pierwszych opisów wykorzystania modelu w przejściu z edukacji do rynku pracy zaproponowała Madeleine Will (1984), która zrobiła to bardzo obrazowo: "Tranzycja to pomost między bezpieczeństwem i uporządkowaniem, jakie oferuje 
szkoła, a ryzykiem w dorosłym życiu". Odnosząc się do ówczesnego prawa obowiązującego w Stanach Zjednoczonych bardziej precyzyjnie, wyjaśnia model tranzycji Suzanne Whitney (2011): „Tranzycja to proces, w ramach którego podejmowane są skoordynowane działania wobec dziecka/ucznia z niepełnosprawnością. Proces ten nastawiony jest na podnoszenie poziomu osiągnięć szkolnych (akademickich) i poprawę funkcjonowania adaptacyjnego (przystosowania) w celu efektywnego przejścia $z$ jednego poziomu edukacyjnego $w$ drugi lub $z$ edukacji do rynku pracy. Wszystkie działania wpierające proces tranzycji bazują na zdiagnozowanych indywidualnych potrzebach ucznia, jego mocnych i słabych stronach oraz zainteresowaniach".

Specjalne potrzeby edukacyjne są rozmaicie uwarunkowane i dają bardzo różny obraz funkcjonalny ucznia. Uwzględnienie indywidualnych potrzeb osoby ma kluczowe znaczenie w sytuacji, w której jej obecność w systemie edukacji powoduje konieczność zastosowania niestandardowych procedur i działań w procesie tranzycji. Warunkami efektywności tego etapu są: całościowe zabezpieczenie rozpoznanych wcześniej indywidualnych potrzeb (niezależne mieszkanie, aktywność zawodowa, aktywny udział w życiu społecznym grupy rówieśniczej, możliwość uczenia się przez całe życie), integracja i współpraca interdyscyplinarnego (międzyresortowego) zespołu w przygotowaniu i realizacji działań wspierających ucznia (absolwenta) (Morningstar 2017). Widać tu bardzo wyraźnie, że interesująca nas szczególnie tranzycja osoby ze specjalnymi potrzebami edukacyjnymi z etapu szkolnego do rynku pracy jest istotnym elementem procesu przejścia z edukacji $w$ dorosłość, a jej efektywna realizacja wymaga uwzględnienia dodatkowych, równie ważnych indywidualnych potrzeb. Niezaspokojenie ich może uniemożliwiać aktywność zawodową. Wyjaśniając przebieg procesu tranzycji, autorka wskazuje bardzo wyraźnie, że punktem wyjścia wszelkich działań planujących i wspierających jego realizację jest "Indywidualny Plan Edukacyjny" (IPE), który powinien zostać uzupełniony o "Plan Tranzycji". Tak, by powstał "Indwidualny Plan Edukacyjno-Zawodowy, IPE-Z".

Przyjmując te wyjaśnienia, oczywiste wydaje się, że efektywne przejście młodych ludzi (szczególnie z SPE) z edukacji do rynku pracy wymaga zaangażowania środowiska, w którym żyją, jego formalnych oraz nieformalnych struktur i elementów. Zakres i stopień tego zaangażowania wyznaczany jest przez potrzeby, jakie ujawnia uczeń, oraz 
przez środowisko jego edukacji, życia (mieszkania) i przyszłej pracy. Istotnym elementem tranzycji jest integracja działań wszystkich podmiotów, które mogą i powinny być $w$ ten proces zaangażowane - organów oświatowych, służb zatrudnienia, pomocy społecznej, instytucji rynku pracy, pracodawców, społeczności lokalnej, rodzin (rys. 2).

Rysunek 2. Organizacja procesu tranzycji z edukacji do rynku pracy ucznia ze specjalnymi potrzebami edukacyjnymi
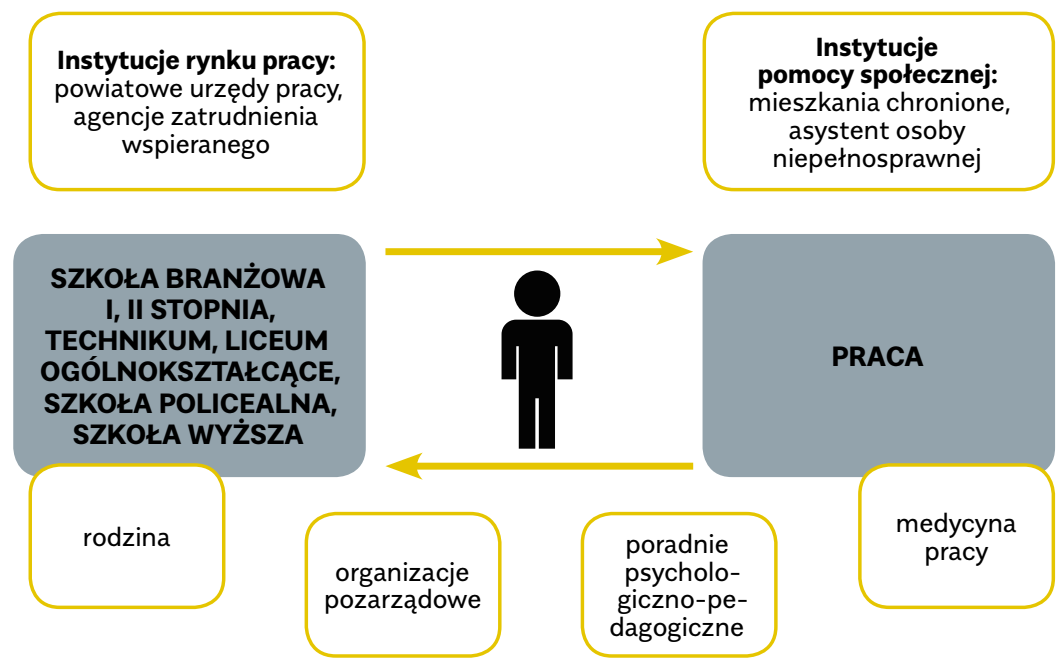

Źródło: Opracowanie własne.

Istotą procesu tranzycji jest pojawienie się skoordynowanych działań służb i instytucji oraz ich współpraca w celu przygotowania absolwenta, a także jego przyszłego środowiska pracy i życia w taki sposób, aby nie musiał on doświadczać statusu bezrobotnego lub poszukującego pracy (pobierać renty: pracowniczą, socjalną lub rodzinną). Dobrym przykładem realizacji (wpierania) tranzycji, choć zarezerwowanym tylko dla absolwentów szkół wyższych, są istniejące od wielu lat Akademickie Biura Karier ${ }^{1}$ Stosowany tam sposób organizacji oddziaływań jest w dużym stopniu podobny do tych podejmowanych $w$ modelu tranzycji. Istnieje 
pilna potrzeba wprowadzenia zmian prawnych w taki sposób, aby absolwenci szkół branżowych przysposabiających do pracy, branżowych I i ll stopnia, techników oraz szkół policealnych i szkół wyższych mogli skorzystać ze wsparcia swojej tranzycji w podobnym zakresie, zgodnie $z$ indywidualnymi potrzebami.

Od kilku lat działa w Polsce innowacyjny program wpierania młodzieży z niepełnosprawnością umysłową w przechodzeniu z edukacji do rynku pracy: „Jestem dorosły - chcę pracować” (Otrębski, Wiącek, Domagała-Zyśk, Sidor-Piekarska 2012). Wykorzystano w nim nowatorską metodykę pracy z uczniem z niepełnosprawnością umysłową i jego środowiskiem oraz z instytucjami rynku pracy, pomocy społecznej i rodziną, uwzględniającą wskazania wynikające z modelu tranzycji dla tej grupy odbiorców. Na potrzeby tego przedsięwzięcia przygotowano i zdigitalizowano 800 stron materiałów edukacyjnych, które od siedmiu lat są wykorzystywane i sprawdzane przez wiele szkół w praktyce. W zeszłym roku opublikowany został kolejny, ciekawy pomysł na realizację procesu tranzycji, który opracowano i testowano jako innowację pedagogiczną w szkołach dla młodzieży niepełnosprawnej umysłowo (Antecka, Bałtowska-Jucha, Głaz-Skirzyńska, Klaro-Celej, Wyszomierska, Zakrzewska 2018). Wykorzystano w nim elementy zatrudnienia wspieranego. Obecność trenera pracy (asystenta osoby niepełnosprawnej) zwiększa szanse na efektywne odnalezienie się na otwartym rynku pracy również przez osoby ze znacznym stopniem niepełnosprawności Te nieliczne, jak dotąd, polskie przykłady mogą być zaczynem kolejnych pomysłów realizowanych na rzecz uczniów z innymi specjalnymi potrzebami edukacyjnymi czy dla uczniów bez niepełnosprawności.

Organizacja i realizacja tego rodzaju działań leży w kompetencjach podmiotów działających w różnych resortach: edukacji, nauki i szkolnictwa wyższego, rodziny, pracy oraz zabezpieczenia społecznego. Jeśli wsparcie udzielane w ramach modelu tranzycji ma być skuteczne, konieczna jest komplementarność działań, a także skoordynowana współpraca interesariuszy. 
Rysunek 3. Komplementarność działań wspierających proces tranzycji młodzieży ze SPE z edukacji do rynku pracy

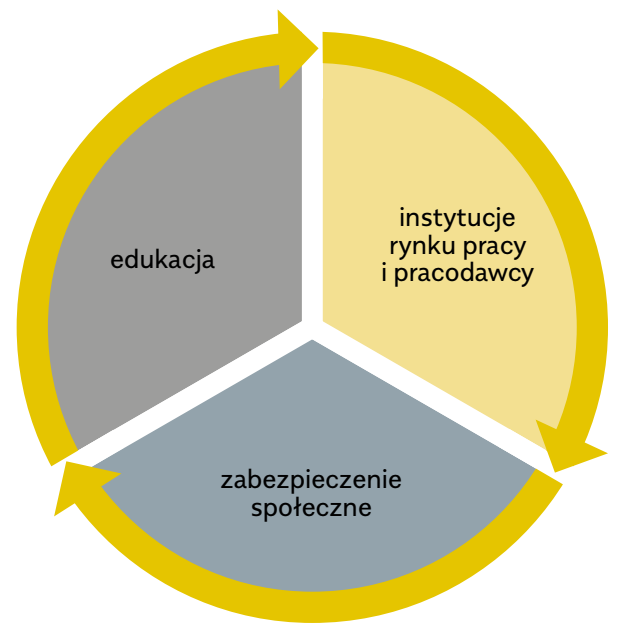

Źródło: Model kształcenia włączającego MEN.

Nie tylko potrzebę, a konieczność wprowadzenia instytucjonalnych rozwiązań dotyczących wsparcia procesu tranzycji z edukacji do rynku pracy młodzieży ze specjalnymi potrzebami edukacyjnymi potwierdzają obowiązujące regulacje prawne oraz polskie i europejskie raporty czy rekomendacje:

$\rightarrow$ Konwencja ONZ o prawach osób niepełnosprawnych (2012),

$\rightarrow$ raport Europejskie wzorce dobrej praktyki kształcenia i szkolenia zawodowego (Europejska Agencja Rozwoju Edukacji Uczniów ze Specjalnymi Potrzebami 2012),

$\rightarrow$ raport Włączajqcy system edukacji i rynku pracy-rekomendacje dla polityki publicznej (IBE 2015),

$\rightarrow$ raport Dowody na zwiq̨zek edukacji włączającej z włączeniem społecznym (Europejska Agencja do spraw Specjalnych Potrzeb i Edukacji Włączającej)², 
$\rightarrow$ rekomendacje Kongresu Osób z Niepełnosprawnościami "Za Niezależnym Życiem" (2018) ${ }^{3}$,

$\rightarrow$ rekomendacje opracowane w ramach projektu "Wspieranie podnoszenia jakości edukacji włączającej w Polsce", realizowanego w ramach Programu Wsparcia Reform Strukturalnych Komisji Europejskiej (lipiec 2018 r. - marzec 2019 r.).

Podsumowując, warto zatrzymać się przez moment nad jednym $z$ uwarunkowań powodzenia procesu tranzycji, w moim odczuciu absolutnie kluczowym i stanowiącym dziś największą barierę w doświadczaniu dorosłości (w tym aktywności zawodowej), szczególnie przez grupę osób niepełnosprawnych na poziomie umiarkowanym i znacznym. Chodzi o zjawisko, które można nazwać „zachowaniem oczekiwanym społecznie". Z moich zawodowych obserwacji polskiego społeczeństwa (prowadzonych od ponad trzech dekad) wnioskuję, że wielu $z$ nas postrzega osoby z niepełnosprawnością jako absolutnie bierne oraz pozostające przez cały czas $w$ roli biorcy pomocy i przeróżnych świadczeń, zupełnie pozbawione autonomii i prawa do podejmowania decyzji dotyczących własnego życia. Im głębsza niepełnosprawność, tym silniej uwidaczniają się te oczekiwania. Potwierdzeniem moich spostrzeżeń są wyniki badań prowadzonych przez Krystynę D. Rzedzicką (2003, s. 114). Autorkę interesowało to, w jaki sposób badani - osoby sprawne - postrzegają relację między niepełnosprawnością a dorosłością człowieka. Uzyskane wyniki bardzo wyraźnie wskazują zróżnicowanie opisu tej relacji:

$\rightarrow$ niepełnosprawność jest przeciwstawna dorosłości (szczególnie kiedy przyczyną jest ograniczenie funkcji umysłowych),

$\rightarrow$ niepełnosprawność jest barierą w osiąganiu dorosłości,

$\rightarrow$ niepełnosprawność może być czynnikiem stymulującym dorosłość (szczególnie motoryczna),

$\rightarrow$ niepełnosprawność i dorosłość są od siebie niezależne.

Konsekwencje opisanych oczekiwań wobec niepełnosprawnych są szczególnie niebezpieczne, jeżeli pochodzą od osób znaczących w ich życiu, takich jak rodzice i nauczyciele lub przedstawiciele podmiotów 
odpowiedzialnych za organizację i dostarczanie wsparcia formalnego i nieformalnego (np. powiatowych centrów pomocy rodzinie, gminnych ośrodków pomocy rodzinie, powiatowych urzędów pracy, organizacji pozarządowych). Świadome lub nieświadome dążenie osób z niepełnosprawnością do spełnienia oczekiwań w zakresie bierności i braku decyzyjności skutkuje negatywnymi konsekwencjami. Nie odczuwają one silnej potrzeby zmiany swojego życia, mają niskie kompetencje w zakresie samodzielnego i odpowiedzialnego podejmowania decyzji, a w konsekwencji nie mogą się w pełni zrealizować na etapie dorosłego życia (Dykcik 2003; Loebl 2003; Bartkowski 2007). 


\subsection{Rodzic w edukacji włączającej jako współuczestnik procesu}

Beata Rola

W rozdziale przedstawione zostały warunki współpracy rodziców dzieci z niepełnosprawnościami ze szkołami. Autorka wskazuje przepisy prawne $w$ tym zakresie i bariery w ich stosowaniu. Zwraca uwagę na znaczenie pojęć "współpraca”, „partnerstwo" i „pomoc” - jako kryteriów sukcesu lub porażki we wzajemnych działaniach na rzecz dziecka. Wskazuje wyznaczniki kultury włączania, odwołując się do takich wyrażeń jak: „tolerancja”, „akceptacja”, „zrozumienie” i „odpowiedzialność”. Scharakteryzowane zostały postawy nauczycieli i rodziców, istotne w procesie zmiany, a także możliwe działania szkoły na rzecz rozwijania współpracy z rodzicami dzieci z niepełnosprawnością.

\section{Słowa kluczowe:}

współpraca

partnerstwo

kultura włączania

tolerancja

akceptacja 


\subsection{Parent as a participant of inclusive education process}

Beata Rola

The chapter presents the terms of cooperation between the school and the parents of children with disabilities. The author describes the law regulations and barriers to its implementation, introduce the terms cooperation, partnership and assistance as well as criteria for success or failure in mutual actions for the child. The article discusses also the concept of inclusion culture using words such as: tolerance, acceptance, understanding and responsibility, the attitudes of teachers and parents important in the process of change, and attempt to define the supporting activities of the school for cooperation with parents of children with disabilities.

\section{Keywords:}

\section{cooperation}

\section{partnership}

inclusion culture

tolerance 
Obecnie istnieje wiele aktów prawnych regulujących stosunki między rodziną a szkołą, niezależnie od tego, czy jest to placówka włączająca, integracyjna czy specjalna. Mają one zasięg zarówno krajowy, jak i globalny. Jednym z ważniejszych dokumentów sankcjonujących te relacje jest Konwencja o prawach dziecka. Zgodnie z jej zapisami każdemu przyznaje się prawo do nauki, umożliwia rozwój osobowości, gwarantuje prawa człowieka i podstawowe wolności. Dokument określa również prawa i obowiązki rodziców oraz gwarantuje pomoc przy ich realizowaniu.

Innym dokumentem o zasięgu europejskim regulującym prawa rodziców w relacji ze szkołą jest Europejska karta praw i obowiązków rodziców, zgodnie z którą mają oni m.in.:

$\rightarrow$ obowiązek angażowania się jako partnerzy w nauczanie ich dzieci w szkole,

$\rightarrow$ prawo dostępu do wszelkich informacji o instytucjach oświatowych, które mogą dotyczyć ich dzieci,

$\rightarrow$ prawo wpływania na politykę oświatową realizowaną w placówkach edukacyjnych, w których uczą się ich dzieci.

Zapisy dotyczące współpracy rodziców ze szkołą odnaleźć można także w Powszechnej deklaracji praw człowieka oraz europejskiej Konwencji o ochronie praw człowieka i podstawowych wolności. Dotyczą one m.in.:

$\rightarrow$ wyboru formy wychowania i rodzaju nauczania ich małoletnich dzieci,

$\rightarrow$ wyboru szkoły dla dziecka,

$\rightarrow$ wychowania dzieci zgodnie z wyznawanymi przekonaniami religijnymi ${ }^{1}$.

Nadrzędnym krajowym dokumentem uwzględniającym prawa rodziców jest Konstytucja Rzeczypospolitej Polskiej. Artykuł 70 stanowi, że "rodzice mają wolność wyboru dla swoich dzieci szkół innych niż publiczne. Oznacza to, że rodzice samodzielnie dokonują wyboru szkoły dla swojego dziecka, kierując się własnymi kryteriami wyboru". Największą rolę w tym zakresie odgrywa Ustawa o systemie oświaty o ochronie praw człowieka i podstawowych wolności, bit.ly/2xQBPvf [dostęp: 15.07.2019]. 
z 7 września 1991 r., która w pierwszym artykule zawiera zapisy o wspomaganiu przez szkołę wychowawczej roli rodziny. W dalszym brzmieniu uściśla obowiązki rodziców dotyczące spełniania obowiązku szkolnego przez dzieci, jak również działalność rad szkół i rad rodziców. Zgodnie z ustawą gremia te mają prawo do:

$\rightarrow$ uchwalania statutu szkoły lub placówki,

$\rightarrow$ przedstawiania wniosku w sprawie rocznego planu finansowego środków specjalnych szkoły lub placówki i opiniowania projektu planu finansowego,

$\rightarrow$ występowania do organu sprawującego nadzór pedagogiczny z wnioskami o zbadanie i dokonanie oceny działalności szkoły lub placówki, jej dyrektora lub nauczyciela,

$\rightarrow$ opiniowania planu pracy, projektu innowacji i eksperymentów pedagogicznych oraz innych spraw istotnych dla szkoły,

$\rightarrow$ oceniania z własnej inicjatywy sytuacji oraz stanu placówki edukacyjnej i występowania z wnioskami do dyrektora, rady pedagogicznej, organu prowadzącego oraz do wojewódzkiej rady oświatowej, szczególnie w sprawach organizacji zajęć pozalekcyjnych i przedmiotów nadobowiązkowych,

$\rightarrow$ uchwalania $w$ porozumieniu $z$ radą pedagogiczną:

a) programu wychowawczego, obejmującego wszystkie treści i działania o tym charakterze skierowane do uczniów,

b) programu profilaktyki dostosowanego do potrzeb rozwojowych uczniów oraz potrzeb danego środowiska, obejmującego wszystkie treści i działania o tym charakterze skierowane do uczniów, nauczycieli i rodziców,

$\rightarrow$ opiniowania programu i harmonogramu poprawy efektywności kształcenia lub wychowania².

Dla rodziców dzieci z niepełnosprawnością szczególne znaczenie mają te zapisy, które bezpośrednio wiążą się z edukacją osób ze specjalnymi potrzebami edukacyjnymi. Zaliczyć do nich należy ich prawo do uczestniczenia w spotkaniach zespołu nauczycieli i specjalistów, opracowującego indywidualny program edukacyjno-terapeutyczny dla danego ucznia. 
Na podstawie opracowanych ram prawnych współpracy można stworzyć zarys (nawet bardzo szczegółowy) dotyczący tego, czego powinno się od rodziców wymagać oraz czego oni mogą oczekiwać od szkoły, jej pracowników i całego systemu edukacji. Same zapisy ujęte w statucie placówki oświatowej, dotyczące organizacji i form współdziałania szkoły z rodzicami w zakresie nauczania, wychowania, opieki i profilaktyki, to wyczerpujący zestaw zagadnień związanych z rolą rodzica w szkole. Odnosi się wrażenie, że obowiązujące przepisy prawa bardzo wspierają (a także w pełni umożliwiają) podjęcie wspólnych działań rodziców i nauczycieli, którzy zmierzają do zwiększenia efektywności pracy szkoły. Jednak, jak pisze Bogusław Śliwerski, „W naszym kraju prawo jest po stronie rodziców, natomiast praktyka po stronie władz oświatowych i szkolnych" (Śliwerski 2016, s. 105). Niejednokrotnie rzeczywistość szkolna potwierdza taki stan rzeczy. Istnieje bowiem wiele luk $w$ procedurach wdrażania prawa oświatowego oraz wiele słabych punktów $w$ zakresie przestrzegania zasad demokratyzacji życia szkoły. Dotyczy to m.in. sztandarowego prawa rodzica do wyboru typu szkoły. Możliwość niezależnej i spójnej z własnymi przekonaniami decyzji bywa ograniczana przez czynniki wynikające z możliwości finansowych rodziców.

Status społeczny rodziny niekiedy obniża się ze względu na wiele wydatków związanych z niepełnosprawnością dziecka lub koniecznością zrezygnowania jednego z rodziców z pracy zawodowej. Zatem nawet jeśli rodzice wybiorą placówkę, która odpowiada ich oczekiwaniom, posłanie do niej dziecka jest często niemożliwe. Miejsce zamieszkania ucznia także bywa barierą w dostępie do wybranej placówki. W sytuacji, gdy szkoła zlokalizowana jest poza obwodem zamieszkania ucznia, ostateczną decyzję o przyjęciu do placówki podejmuje jej dyrektor, a nie rodzic. Mamy zatem tutaj również do czynienia z sytuacją, w której mimo zapisów prawa umożliwiających nieograniczony dostęp do edukacji uczniom z niepełnoprawnością, w praktyce nie da się ich wyegzekwować. Podobnie jest z umożliwieniem rodzicom uchwalania, w porozumieniu z radą pedagogiczną, programu wychowawczego szkoły i programu profilaktyki dostosowanego do potrzeb rozwojowych uczniów oraz potrzeb danego środowiska. Jeśli rada rodziców nie zgadza się z założeniami zawartymi w którymś z programów i w terminie 30 dni od dnia rozpoczęcia roku szkolnego nie podpisze takiego dokumentu, może tego dokonać dyrektor razem z organem 
sprawującym nadzór pedagogiczny. Nawet tak podstawowe zadanie szkoły, jakim jest wspomaganie wychowawczej funkcji rodziny i dostarczanie rodzicom informacji o postępach i trudnościach ucznia, nie jest w pełni realizowane. Wpływają na to zarówno pogłębiające się różnice wynikające z poglądów, przekonań i wartości między nauczycielami a rodzicami, jak i coraz częściej pojawiające się odmienne podejście obu grup do tematyki wychowania, rozumienia roli, celów oraz istoty placówki edukacyjnej i rodziny. Nie ułatwia tego także utrzymujący się od dawna brak kompetencji interpersonalnych i komunikacyjnych nauczycieli. Trudności z realizacją założeń prawa oświatowego potwierdza sprawozdanie Rzecznika Praw Obywatelskich z wykonania przez Polskę postanowień Konwencji, w którym odnajdujemy zapis: „Można zatem uznać, że ogólne ramy prawne pozwalają na realizację prawa osób z niepełnosprawnościami do edukacji. Wyzwaniem są jednak niektóre przepisy szczegółowe, które sprawiają, że choć prawo do edukacji może być realizowane, to nie istnieją odpowiednie rozwiązania prawne gwarantujące właściwą realizację dostępu do edukacji i egzekucję prawa" ${ }^{3}$.

Współpraca szkoły z rodzicami uczniów ze specjalnymi potrzebami edukacyjnymi wymaga zatem szerszych zobowiązań niż tylko realizacji zapisów prawnych. Kluczowe stają się działania na rzecz rozumienia znaczenia poszanowania prawa i wpływu uregulowań legislacyjnych na uspołecznienie środowiska szkolnego. W tym celu konieczna jest praca nad przemodelowaniem społecznej mentalności, nad zmianą ludzkich nastawień i eliminowaniem stereotypów. Wiąże się to zarówno z potrzebami i wyzwaniami czasu, jak i z koniecznością tworzenia coraz lepszych warunków realizacji procesu edukacyjnego. Obecnie zarówno rodzice, jak i szkoła mają świadomość, że wzajemnie się uzupełniają

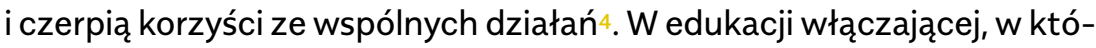
rej skuteczność przebiegu rewalidacji zależy szczególnie od współpracy obu podmiotów, wspólna praca na rzecz dobra dziecka staje się wręcz kluczowym zadaniem szkoły. O znaczeniu, formach i rodzajach tych działań powiedziano już chyba wszystko. Istnieje wiele praktycznych Polską w celu implementacji postanowień Konwencji o prawach osób niepełnosprawnych w latach 2015-2017. 
poradników dla nauczycieli, które zawierają wskazówki co do współpracy szkoły z rodzicami uczniów ze specjalnymi potrzebami edukacyjnymi ${ }^{5}$. Nie brakuje pozycji wydawniczych skierowanych do dyrektorów szkół, których treści dotyczą organizacji wspólnych działań wychowawców, specjalistów i nauczycieli z rodzicami uczniów z dysfunkcjami ${ }^{\circ}$. Również rodzice mogą skorzystać z publikacji poświęconych temu, jak wspólnie ze szkołą i kadrą pedagogiczną wspierać działania dla dobra dziecka. Nauczyciele także doceniają wagę wzajemnych pozytywnych relacji. Dlaczego zatem nadal słyszymy o trudnościach $w$ tym obszarze?

Jeśli uznamy, że szkoła to nie tylko instytucja, ale także miejsce tworzone przez ludzi, którzy wnoszą do niej swoje potrzeby i swój sposób widzenia świata, to na plan pierwszy wysuwa się kwestia relacji, kontaktów międzyludzkich oraz stworzenia atmosfery szacunku i życzliwości, poszanowania i akceptacji. W placówce realizującej edukację włączającą widać nieco wyraźniej, że grupa rodziców jest bardzo niejednorodna. Część z nich to osoby świadome, wymagające oraz darzące szkołę zaufaniem i wierzące w fachowość kadry edukacyjnej. Są one skłonne do zaangażowania - nie tylko wspomagania nauczycieli, ale także spierania się z nimi dla dobra dziecka. Część to rodzice niezainteresowani tym, co dzieje się w szkole. Posyłają do niej dzieci z niepełnosprawnością z nadzieją, że otrzymają tam one stosowną opiekę, wychowanie i nauczanie. Kolejna grupa to osoby z dodatkowymi trudnościami, które poza opieką nad dzieckiem z niepełnosprawnością doświadczają innych trudności życiowych, traktując niekiedy szkołę jako dodatkowy obowiązek lub oczekując od niej wsparcia posuniętego do granic wyręczania w tym, co tylko możliwe. Sami nauczyciele są również bardzo niejednorodnym środowiskiem, zróżnicowanym ze względu na: staż pracy, doświadczenia zawodowe, rodzaj placówki, w której pracują, system wartości i światopogląd czy przygotowanie do zawodu i roli wychowawcy w edukacji włączającej. Poszczególne grupy mają zatem różne oczekiwania względem samych siebie, osób, z którymi przyjdzie im współpracować, a także wobec idei edukacji włączającej i wizji współpracy. Bez postaw opartych na tolerancji i akceptacji nie da się rozwiązać ani nawet złagodzić żad[dostęp: 15.06.2019]. 
nego kryzysu wynikającego z występującego zróżnicowania. Problemów jest jednak dużo więcej i są one coraz trudniejsze.

Z tolerancją wiążą się nieodłącznie: wiedza, intelekt, odwaga, otwartość i doświadczenie. Ważna jest także umiejętność rozpoznawania własnego lęku oraz zdolność do konstruktywnego przetwarzania go w postawę sprzyjającą kontaktom z innymi. W relacjach z rodzicami dzieci z niepełnosprawnością istotna staje się umiejętność wyrażania uznania dla ich wiedzy i zaangażowania, życzliwość, cierpliwość, wyrozumiałość oraz dostrzeganie w każdym z nich ważnej osoby, a nie tylko anonimowego członka grupy. Wymaga to od nauczycieli wiedzy pedagogicznej i psychologicznej oraz wielu kompetencji interpersonalnych, szczególnie umiejętności inicjowania spotkań i prowadzenia rozmów na tematy trudne i bolesne. Niestety, kadra pedagogiczna często bagatelizuje te obszary, a braki w umiejętnościach interpersonalnych nie są dla niej źródłem dyskomfortu zawodowego. W ocenie rodziców nauczyciele nadal tworzą sporo barier komunikacyjnych. Bardzo często stawiają się w pozycji osoby dominującej i protekcjonalnie uświadamiającej rodzica (Żejmis, Jurga 2016).

W tym wymiarze szczególnego znaczenia nabierają pojęcia takie jak: współpraca, współdziałanie, partnerstwo. Mimo wielokrotnego odwoływania się do nich w relacjach szkoła - rodzic, nadal budzą kontrowersje i są powodem nieporozumień. Mieczysław Łobocki terminów tych używa zamiennie. Głównie uwypukla łączące je określenie samego celu "jako wspólnego działania rodziców i nauczycieli dla osiągnięcia dobra poszczególnych uczniów, klas, a nawet całej społeczności szkolnej w procesie nauczania i wychowania" (Łobocki 1985). Innymi słowy, współpraca i współdziałanie to przede wszystkim podejmowanie różnych zadań w imię wspólnie uzgodnionych celów. Zalicza się do nich także te działania, które wykonywane są tylko przez nauczycieli lub tylko przez rodziców, zgodnie z podjętą przez nich uprzednio decyzją w tej sprawie. Układ osób współdziałających jest taki, że jedni odgrywają rolę wiodącą, a drudzy, rozumiejąc konieczność takiej realizacji działań, włączają się w ten proces, niekoniecznie ze świadomością celów końcowych. Spełnienie powyższych oczekiwań bywa szczególnie trudne w kontekście współpracy szkoły z rodzicami uczniów ze specjalnymi potrzebami edukacyjnymi. W natłoku codziennych obowiązków związanych z niepełnosprawnością dzieci opiekunowie często nie mają przestrzeni na dodatkowe działania i dociekanie 
celów pracy nauczyciela. To właśnie brak zrozumienia motywów działania i zgubienie sensu zadań cząstkowych jest źródłem wielu nieporozumień. Ograniczenia aktywności rodziców uczniów ze specjalnymi potrzebami edukacyjnymi, wynikające z trudnej sytuacji życiowej, dodatkowo sprzyjają występowaniu napięć i nieporozumień. Szkoły muszą zatem wziąć pełną odpowiedzialność za kierowanie tym procesem, czyli za dokładne omówienie zasad współdziałania, określenie obowiązków obu stron i sposobu ich egzekwowania. Rzeczywistość jednak bywa nieco inna - często rodzice i przedstawiciele szkół nie wiedzą, jakie zadania mają wykonać w ramach wspólnych działań. Brakuje konkretnego programu pracy i uświadomienia własnych ograniczeń wynikających z podziału obowiązków.

Jeśli współpraca generuje problemy, to być może partnerstwo spełni oczekiwania zarówno rodziców, jak i nauczycieli. Zakłada ono osiąganie celu, ale w bardziej sformalizowanej formie, dopuszczającej istnienie względnej równości. Podstawą nawiązywania tego typu stosunków jest autentycznie odczuwana, nienarzucana z zewnątrz wola kontaktu z inną osobą. W myśl tej zasady nauczyciele oczekują od rodziców zaangażowania i pełnego zrozumienia ich działań, przy uwzględnienieniu równości ról. Zdaniem Jacka Kielina, oczekiwanie od rodziców partnerstwa jest jednak błędem (Kielin, Klimek-Markiewicz 2016). Nie będą oni nigdy dla terapeutów równorzędnymi partnerami w procesie leczenia, gdyż mimo wielkich chęci, gorącego serca i miłości, jaką darzą swoje dziecko, nie mają zawodowego przygotowania, specjalistycznej wiedzy i nie posiadają predyspozycji potrzebnych do pracy terapeutycznej. Stawianie w edukacji na partnerskie relacje to budowanie nierealnych oczekiwań, które nie są rozumiane i spełniane (Kielin 2012). Zmniejsza to jedynie wzajemne zaufanie i lojalność.

W złożonej sytuacji życiowej rodziców dzieci z niepełnosprawnościami lepszym rozwiązaniem jest udzielanie im szeroko rozumianej pomocy. W przestrzeni szkolnej odnosi się to do działań nauczycieli i specjalistów w kierunku pełnej odpowiedzialności za proces edukacyjny uczniów. Współuczestnictwo rodziców uznawane jest wówczas za możliwość, a nie konieczność. „Rodzice potrzebują pomocy i rady, żeby podtrzymać poczucie własnej kompetencji wychowawczej, przecież wychowując dziecko specjalnej troski, ponoszą oni porażki i niepowodzenia; postępy dziecka są powolne, trudno zauważalne, zachowanie nierzadko zaburzone. Rodzicom potrzebna jest nie tylko 
rada, ale również akceptacja i podtrzymanie ze strony nauczyciela - wychowawcy. Nie można zapominać o tym, że i nauczycielom potrzebne jest poczucie, że cieszą się szacunkiem i uznaniem" (Olechnowicz 1979).

Pomoc udzielana rodzicom dziecka z niepełnosprawnością musi być wieloaspektowa, wielowymiarowa. W szkole może ona być wyrażona poprzez wsparcie:

$\rightarrow$ emocjonalne (polegające na tworzeniu więzi atmosfery wzajemnego zaufania, akceptacji i troski), wyrażane przez komunikaty werbalne i niewerbalne,

$\rightarrow$ informacyjne, dotyczące udzielania porad, wskazówek niezbędnych do zrozumienia niepełnosprawności dziecka, istotna jest również wymiana doświadczeń, wspólnych spostrzeżeń,

$\rightarrow$ wartościujące, które polega na akceptacji, docenieniu potencjału rodzica (Kawczyńska-Butrym 1998).

Tak rozumiana pomoc umożliwia zarówno rodzicom, jak i nauczycielom wyeksponowanie kompetencji przynależnych do pełnionych przez nich funkcji. Za taką perspektywą przemawia wielokrotnie już przywoływany fakt, że organizowanie działań na rzecz wspólnego osiągania określonych efektów w kształceniu jest zbyt obciążające dla rodziców dzieci ze specjalnymi potrzebami edukacyjnymi. Oczekiwanie i wymaganie od nich zaangażowania paradoksalnie wywołuje skutki odwrotne do zamierzonych. Jest raczej przyczyną powstawania oporu niż zacieśniania współpracy. W takim podejściu upatruje się przyczyn niskiej efektywności roli rodziców w szkole, mimo wielu starań nauczycieli. W opinii tych pierwszych ważne są bardzo proste rozwiązania: "by mówić dobre, ale realne rzeczy, słuchać tego, co mają do powiedzenia, nie ukrywać niewiedzy w danym obszarze i otwarcie się do niej przyznać, zauważyć i docenić ich działania i postępy dziecka, szukać wsparcia innych osób, jeśli istnieje taka potrzeba" (Żejmis, Jurga 2016). Jak widać, są to oczekiwania odnoszące się do omawianego już aspektu relacji. Nie mogą być one w pełni realizowane bez zmian postaw, wartości, nastawień czy przekonań zarówno nauczycieli, jak i rodziców. Wymaga to od szkoły zagospodarowania przestrzeni związanej z kulturą włączania.

Truizmem jest stwierdzenie, że rodzina wraz ze szkołą uczą dzieci norm i zasad postępowania. Oczywiste jest także, że jakość umiejęt- 
ności, postaw i nawyków kształtowanych w tych środowiskach jest szczególnie ważna w wymiarze budowania relacji interpersonalnych. W procesie kształtowania podejścia do edukacji włączającej powyższe spostrzeżenie wydaje się jednak kluczowe, oznacza bowiem, że znaczenie ma, jakie postawy, poglądy i nastawienia przejawiają opiekunowie i wychowawcy. Istotne staje się to, czy mają oni pozytywne, otwarte poglądy na temat stosowania inkluzji w praktyce. A także czy są również świadomi tego, jak ważną rolę w formowaniu postaw w całym środowisku szkolnym odgrywa przykład, który dają swoim postępowaniem.

Z raportu o wdrażaniu Konwencji o prawach osób niepełnosprawnych wynika7, że założenia formalne inkluzji są akceptowane i w większości szkół realizowane. Wiąże się to z działaniami na rzecz dostosowania programów nauczania, indywidualizacji metod i form pracy, wyborem odpowiednich pomocy dydaktycznych i sprzętu specjalistycznego, a także przygotowaniem infrastruktury szkolnej. Nadal jednak w szkołach ogólnodostępnych, do których uczęszczają uczniowie z niepełnosprawnością wybrzmiewają poglądy niekiedy sprzeczne z założeniami edukacji włączającej. Mimo upowszechnienia aktów prawnych o charakterze międzynarodowym (takich jak Powszechna deklaracja praw człowieka, Konwencja praw dziecka, Światowa deklaracja edukacji dla wszystkich, Deklaracja z Salamanki czy Międzynarodowa konwencja praw osób żyjących z niepełnosprawnością), wielu rodziców i nauczycieli obecność osób z niepełnosprawnością w systemie oświaty traktuje jedynie jako przywilej, a nie naturalny proces wynikający z przysługującego im prawa. Widoczne jest to wówczas, gdy rodzic zgłasza do dyrektora, że nie zgadza się, aby uczeń z niepełnosprawnością uczęszczał do klasy, w której uczy się jego sprawne dziecko. Duża część dyrektorów i nauczycieli zastanawia się, jakie kroki można podjąć, aby wyjść naprzeciw sugestii rodzica. W sytuacji odwrotnej, kiedy rodzic dziecka z niepełnosprawnością zgłosiłby brak zgody na uczestniczenie dziecka sprawnego w lekcjach, nikt nie potraktowałby tej sugestii poważnie. Żaden z dyrektorów nie podjąłby nawet dyskusji wokół tak postawionego problemu. Argument jest oczywisty. Każdy uczeń, jako obywatel, 
ma prawo uczęszczania do szkoły powszechnej. Dlaczego zatem nie ma takiego myślenia, gdy chodzi o dzieci niepełnosprawne?

Dopóki w świadomości nauczycieli, dyrektorów i rodziców nie ugruntuje się przekonanie, że niepełnosprawność nikomu nie odbiera praw obywatelskich, dopóty będziemy mówić o mentalnym wykluczaniu i braku "ducha inkluzji" w szkołach. Tego rodzaju podejście kładzie się cieniem na wszystkie działania w szkole. Zmniejsza gotowość nauczycieli do poznawania innowacyjnych metod pracy, otwartość na nowe doświadczenia, ciekawość związaną ze sposobem funkcjonowania uczniów z niepełnosprawnością i zaangażowanie w ich życie rodzinne. Osobliwość wpływów szkoły w tym obszarze polega na tym, że jest ona zobligowana rozporządzeniami Ministra Edukacji Narodowej ${ }^{8}$ do udzielania pomocy psychologiczno-pedagogicznej nie tylko każdemu uczniowi, który tego potrzebuje, ale również jego rodzicom. Stwarza to wiele możliwości zadbania o sferę związaną z dialogiem społecznym i pracą w zakresie postaw oraz wartości istotnych z punktu widzenia omawianej problematyki.

Podsumowując, uznać można, że we współpracy szkoły z rodziną dominuje nastawienie na skuteczność i efekty. Każde działanie jest oceniane według rezultatów i czynności, które przynoszą określone korzyści edukacyjne. Coraz ważniejsze staje się wyznaczanie zadań i ich realizacja oraz wypełnienie zapisów prawa, a mniejsze znaczenie ma budowanie i utrzymywanie wzajemnych więzi. Jak na razie takie podejście nie prowadzi do sukcesu. Jest raczej źródłem dyskomfortu i zaniechania współpracy. Tworzy to nie tylko niesprzyjające środowisko kształcenia, ale także uniemożliwia formowanie odpowiednich postaw wobec nowych wyzwań edukacyjnych. Dlatego wydaje się zasadne, aby w budowaniu relacji między szkołą a rodzicami uczniów z niepełnosprawnością w większym stopniu zadbać o klimat wspólnej pracy, wzajemne zrozumienie i interakcje zachodzące między ludźmi. Rodzina z takim dzieckiem powinna być ujmowana systemowo, a dostarczane wsparcie powinno mieć charakter interdyscyplinarny, aby rodzice nie czuli się osamotnieni i bezradni ze względu na sytuację, w jakiej się znaleźli. 
Zmiany w szkole można zacząć od małych kroków. Najważniejszym filarem tych zmian powinno być budowanie atmosfery wzajemnego zaufania oraz wspieranie, wspieranie i jeszcze raz wspieranie rodziców. W związku z tym warto zwrócić uwagę na rozwiązanie, które sprawdza się w wielu szkołach, czyli tzw. pokój rodzicielski. Służy on nie tylko do spotkań z rodzicami i budowania komfortowej atmosfery podczas rozmów, ale przede wszystkim sprawia, że mają oni poczucie swojego miejsce w szkole. Równie priorytetowe jest wypracowanie spójnych zasad organizowania takich spotkań. Ważny jest zarówno moment powitania rodzica, jak i zakończenia rozmów. Podanie ręki i odprowadzanie do drzwi to dość oczywisty sposób traktowania gościa (a w szkole tego typu gesty i zachowania nie są zbyt często spotykane).

Warto również pomyśleć o tym, by rodzice podczas dni otwartych mogli przemieszczać się bez kontroli nauczycieli po szkole i klasach, w których uczą się ich dzieci. Umożliwienie swobodnego oglądania dziecięcych prac, ciekawych projektów czy dokumentacji z życia klasy pozwoli rodzicom poczuć, że są mile widziani w placówce. Podobną funkcję może pełnić kącik dla rodziców - wydzielone miejsce (np. przy wejściu do klasy), w którym znajduje się tablica dla nich przeznaczona. Dzięki tej formie kontaktu mogą oni zapoznać się z interesującymi artykułami lub książkami opisującymi problematykę funkcjonowania dziecka, w tym także np. specyfikę wybranej niepełnosprawności.

$W$ relacji nauczyciel - rodzic wiele zmienia formuła zajęć otwartych. Umożliwia ona obserwowanie dziecka (także z niepełnosprawnością) w czasie zajęć w gronie rówieśników. Weryfikacja umiejętności dzieci i zasobu ich wiadomości oraz indywidualnych problemów z tym związanych często uświadamia rodzicom trudności, z jakimi borykają się pedagodzy. Zdarza się, że sama gotowość nauczycieli do tak otwartego kontaktu budzi wśród rodziców szacunek i zaufanie. Zajęcia otwarte mogą mieć także charakter warsztatów, podczas których rodzice z dziećmi realizują wspólny projekt (np. wykonanie kartek świątecznych, pisanek na zajęciach plastycznych). W klasie, do której uczęszcza uczeń z niepełnosprawnością, takie spotkanie jest doskonałą okazją do integrowania się i pogłębiania więzi emocjonalnej na różnych poziomach.

W grupie integracyjnej ważną rolę ogrywają spotkania z udziałem eksperta. Może to być osoba zaproponowana przez nauczyciela, gdy potrzebuje on wsparcia autorytetu, lub też specjalista, który od- 
powie na problemy rodziców. Pedagogizacja rodziców powinna jednak polegać nie tyle na teoretycznych wykładach, ile na dyskusji na konkretne tematy i wspólnym analizowaniu problemów wynikających z sytuacji życiowych. Niektóre z tematów można zaplanować z góry (np. na początku roku szkolnego), inne pojawiają się doraźnie - wynikają $z$ aktualnych potrzeb i sytuacji w klasie. Istotne jest jednak systematyczne zasięganie opinii rodziców (np. z wykorzystaniem ankiet) na tematy dotyczące działalności szkoły/klasy i oczekiwań wobec placówki, nawet gdyby niemożliwe stało się ich zaspokojenie.

Ważną, choć mało rozpowszechnioną formą współpracy jest odwiedzanie przez nauczycieli domów swoich podopiecznych. Jest to zadanie trudne, ale w niektórych wypadkach konieczne. Szczególnie wówczas, gdy uczniowie sprawiają trudności i nauczyciele nie są w stanie zrozumieć podłoża zachowań dziecka. Wizyta domowa jest doskonałą okazją nie tylko do nawiązania życzliwej relacji, ale także do zasięgnięcia u źródła informacji dotyczących rozwoju dziecka, jego trybu życia, upodobań lub stanu zdrowia w celu pełniejszej diagnozy pedagogicznej i realnej oceny zakresu współpracy. W tym obszarze działań mieści się również bliższe poznanie rodziny dziecka w sytuacjach pozaszkolnych, w miejscach i okolicznościach neutralnych, takich jak: obóz rehabilitacyjny, wycieczka, ognisko czy impreza szkolna organizowana w czasie dogodnym dla rodziców.

Rozmowy telefoniczne oraz kontakt mailowy to standardowe formy komunikacji, zapomina się jednak o innych rozwiązaniach sprzyjających współpracy. Mogą to być listy, dyplomy, pisma pochwalne wysyłane do rodziców, które mogą sprzyjać zadowoleniu z osiągnięć dziecka. Często budzą dumę, podnoszą zaufanie do placówki i zwiększają zaangażowanie w życie szkoły - zarówno ucznia, jak i członków jego rodziny. Ogólną zasadą, którą należy się tu kierować, jest pozyskiwanie zaufania i życzliwości rodziców, czego raczej nie uda się osiągnąć, informując ich podczas spotkań jedynie o brakach i wadach ich dzieci.

Oprócz spotkań ogólnych warto pomyśleć także o niestandardowych formach komunikacji, takich jak wymiany informacji między trzema stronami: rodzicami, nauczycielami i uczniami. To rozwiązanie polega na rozmowie o sprawach dzieci w obecności głównych zainteresowanych stron. Stwarza okazję, by wszyscy uczestnicy mogli wyrabiać w sobie poczucie sprawstwa, uczyć się wspólnie rozwiązywać problemy i przejmować odpowiedzialność za cały proces edukacyjny. 
Trudno pominąć w działaniach na rzecz efektywnej współpracy ze szkołami organizowanie zewnętrznych grup wsparcia dla rodziców (bez udziału jej pracowników) oraz zachęcanie ich do tworzenia struktur formalnych, współdziałających z placówką (rada szkół, stowarzyszenie, fundacja). Doskonałą formą integrowania się grupy są także uroczystości szkolne - dla wielu osób jest to jeszcze jedna okazja do lepszego poznania dzieci i atmosfery panującej w placówce. Dla uczniów, szczególnie z niepełnosprawnością, tego typu wydarzenia są okazją do wykazania się posiadanymi zdolnościami i umiejętnościami. Wycieczki z kolei pozwalają na podejmowanie wspólnie z rodzicami decyzji i uwzględnianie indywidualnych możliwości psychofizycznych każdego ucznia. Dzięki takiej aktywności osoby z zewnątrz mogą dostrzec różnorodność wyzwań, przed którymi stoją nauczyciele, i docenić ich trud w realizowaniu potrzeb oświatowych wszystkich uczniów.

W edukacji grupy z niepełnosprawnością, częściej niż w przypadku uczniów sprawnych, wspólną przestrzenią działań rodziców i nauczycieli są prace domowe. W tej sytuacji konieczne jest, by pedagog był osobą decydującą od początku do końca o sposobie nauczania i uczenia się podopiecznego. Jeżeli dziecko nie będzie potrafiło się czegoś nauczyć, to do nauczyciela należy znalezienie sposobu na poradzenie sobie $z$ tą sytuacją, a rolą rodzica - jedynie wsparcie całego procesu. W tak rozumianym systemie nauczyciel wspomaga zarówno ucznia, jak i jego rodzica.

W niniejszym tekście nie udało się wymienić wszystkich możliwości współpracy szkoły z rodzicami uczniów z niepełnosprawnością, m.in. dlatego, że obszarów takiego współdziałania jest wiele. Zależą one nie tylko od specyfiki placówki edukacyjnej, ale i od potrzeb danej społeczności szkolnej. Warto jednak podkreślić, że to głównie od kompetencji nauczycieli i ich osobowości zależy, czy współpraca będzie dla rodziców procesem łatwym czy trudnym. Podsumowując, można zatem stwierdzić, że dobry nauczyciel może znaczyć więcej dla budowania współpracy, niż świetna organizacja czy najbardziej nawet dopracowany system edukacyjny. 



\subsection{Nowa rola placówek specjalnych}

Anna Tomaszewska

W rozdziale omówiono nową rolę placówek specjalnych, jako Specjalistycznych Centrów Wspierania Edukacji Włączającej. Od wielu lat trwa debata na ten temat. Jest to ważna kwestia w dobie zmian w myśleniu o edukacji uczniów z niepełnosprawnościami oraz w kontekście ratyfikowanej w 2012 r. przez Polskę Konwencji o prawach osób niepełnosprawnych. Coraz więcej rodziców dla swoich dzieci wybiera szkoły ogólnodostępne, czyli tzw. edukację włączającą, jednak aby kształcenie było skuteczne, szkoła powinna otrzymać specjalistyczne wsparcie. W tym kontekście została przedstawiona nowa rola placówek specjalnych: cele, zadania, organizację oraz warunki konieczne do ich osiągnięcia i realizacji. W rozdziale wzięto pod uwagę doświadczenia placówek specjalnych, wnioski z debat oraz Rekomendacje Europejskiej Agencji do spraw Specjalnych Potrzeb i Edukacji Włączającej.

\section{Słowa kluczowe:}




\subsection{A new role of special schools}

Anna Tomaszewska

The article discusses a new role of special schools as Specialist Support Centers for Inclusive Education. The debate has been going on for many years. This is an important topic in the period of changes in thinking about the education of students with disabilities and in the context of the Convention on the Rights of Persons with Disabilities, ratified by Poland in 2012. More and more parents of pupils with disabilities choose mainstream schools, i.e. inclusive education. To make education effective, the school should get specialist support. A new role of special schools has been presented: goals, tasks, organization and conditions necessary to achieve and implement them. The article is based on experience of special schools, conclusions from debates and recommendations of the European Agency for Special Needs and Inclusive Education.

\section{__ Keywords:}




\section{Stan obecny}

W Polsce od ponad dziesięciu lat trwa dyskusja dotycząca miejsca i warunków kształcenia uczniów ze specjalnymi potrzebami edukacyjnymi. Ministerstwo Edukacji Narodowej wielokrotnie podejmowało ten temat. Prowadzone były konsultacje i debaty społeczne. Różne gremia powoływały zespoły eksperckie w celu opracowania modelu nauczania osób z tej grupy. Intensyfikacja prac nastąpiła w 2012 r. po ratyfikowaniu przez Polskę Konwencji o prawach osób niepełnosprawnych, sporządzonej w Nowym Jorku w dniu 13 grudnia 2006 r.

Placówki kształcenia specjalnego, od przedszkoli poczynając, a na szkołach specjalnych i ośrodkach szkolno-wychowawczych kończąc, od wielu lat działały w celu integracji społecznej podopiecznych z niepełnosprawnościami (np. inicjowały kontakty z ich sprawnymi rówieśnikami). Realizacja tych zadań miała na celu m.in. włączenie społeczne.

Każda placówka specjalna w ramach swojej misji przygotowuje podopiecznych do osiągnięcia maksymalnej samodzielności, aby w przyszłości - zgodnie ze swoimi możliwościami psychofizycznymi - mogli prowadzić niezależne życie i odgrywać takie same role społeczne, jak ich pełnosprawni rówieśnicy. Ponadto, placówki zawodowe specjalne w procesie kształcenia wyposażają uczniów niepełnosprawnych w odpowiednie kompetencje i umiejętności umożliwiające podjęcie przez nich pracy na otwartym rynku pracy, w zakładzie pracy chronionej lub $w$ ramach zatrudnienia wspomaganego.

W polskim systemie oświaty dzieci i młodzież otrzymują orzeczenie o potrzebie kształcenia specjalnego (wydawane przez publiczne poradnie psychologiczno-pedagogiczne) ze wskazaniem rodzaju niepełnosprawności lub sprzężenia. Edukacja może odbywać się w szkole zarówno ogólnodostępnej, jak i integracyjnej czy specjalnej. Decyzję o wyborze przedszkola czy szkoły dla swojego dziecka podejmują rodzice lub prawni opiekunowie. Wybór typu placówki wiąże się z konsekwencjami. Jeżeli jest to szkoła ogólnodostępna, najbliższa miejsca zamieszkania, to dziecko przebywa w swoim naturalnym środowisku, żyje w pobliżu rówieśników, z którymi się uczy w klasie. Jednak w rzeczywistości oświatowej zdarza się, że placówka nie jest przygotowana do podjęcia edukacji i rewalidacji ucznia z danym rodzajem niepełnosprawności. Przepisy prawa obligują ją do przyjęcia każdego dziecka mieszkającego w jej rejonie, niezależnie od stopnia i rodzaju potrzeb. 
W sytuacji, gdy jest to osoba z orzeczeniem o potrzebie kształcenia specjalnego, szkoła zobowiązana jest do zapewnienia odpowiednich warunków, specjalistycznych pomocy dydaktycznych wspomagających edukację, dostosowanych podręczników (np. w brajlu lub z powiększonym drukiem dla ucznia z dysfunkcją narządu wzroku) oraz realizację zaleceń zawartych w orzeczeniu. Jest to ogromne wyzwanie dla współczesnej szkoły $-\mathrm{z}$ jednej strony jest obowiązek narzucony przepisami prawa, z drugiej brak doświadczenia, specjalistów, wyposażenia i wsparcia. Obecnie szkoły ogólnodostępne albo kształcą swoich nauczycieli w zakresie pedagogiki specjalnej, najczęściej oligofrenopedagogiki, albo zatrudniają nauczyciela pedagoga specjalnego do prowadzenia zajęć rewalidacyjnych (dla jednego ucznia z orzeczeniem w wymiarze dwóch godzin tygodniowo). Dotyczy to szczególnie pedagogów specjalnych w zakresie niepełnosprawności sensorycznych. Jeżeli szkoła ogólnodostępna zatrudni nauczyciela z placówki specjalnej, to dysponuje on zapleczem zarówno w formie odpowiednich pomocy dydaktycznych, jak i możliwości konsultacji z kolegami. Jeżeli jednak nauczyciel pedagog specjalny jest zatrudniony tylko w kilku szkołach ogólnodostępnych, nie ma takich możliwości.

Zgodnie z obowiązującymi przepisami prawa, instytucjami wskazanymi do wspomagania szkół ogólnodostępnych są: placówki doskonalenia nauczycieli, poradnie psychologiczno-pedagogiczne i biblioteki pedagogiczne, które na to zadanie otrzymują subwencję oświatową. Jednak, jak pokazują praktyka i badania, nie mogą one sprostać wszystkim potrzebom.

W Rozporządzeniu Ministra Edukacji Narodowej z dnia 9 sierpnia 2017 r. w sprawie warunków organizowania kształcenia, wychowania i opieki dla dzieci i młodzieży niepełnosprawnych, niedostosowanych społecznie i zagrożonych niedostosowaniem społecznym, w par. 6.1.4, indywidualny program edukacyjno-terapeutyczny określa, „w zależności od potrzeb, zakres współdziałania ze specjalnym ośrodkiem szkolno-wychowawczym".

W innym Rozporządzeniu Ministra Edukacji Narodowej z dnia 2 listopada 2015 r. w sprawie rodzajów i szczegółowych zasad działania placówek publicznych, warunków pobytu dzieci i młodzieży w tych placówkach oraz wysokości i zasad odpłatności wnoszonej przez rodziców za pobyt ich dzieci w tych placówkach, par. 47 wskazuje, że "specjalny ośrodek szkolno-wychowawczy współpracuje ze szkoła- 
mi ogólnodostępnymi w zakresie diagnozowania i rozwiązywania problemów dydaktyczno-wychowawczych uczniów niepełnosprawnych uczęszczających do tych szkół".

Niestety, w rozporządzeniach nie podano szczegółowych zadań ani sposobu finansowania wspomnianej współpracy. Z doświadczenia wynika, że każdy specjalny ośrodek szkolno-wychowawczy wspiera szkoły ogólnodostępne w różnym zakresie w ramach dostępnych możliwości. Najczęściej nauczyciele specjaliści wykonują tę pracę „po koleżeńsku”, mając na uwadze przede wszystkim dobro niepełnosprawnego dziecka. Ośrodki organizują także seminaria i warsztaty, na które zapraszani są nauczyciele, rodzice oraz pracownicy poradni psychologiczno-pedagogicznych.

\section{Nowa rola placówek specjalnych}

W obecnej rzeczywistości polskiej oświaty, ze względu na to, że coraz więcej rodziców dzieci niepełnosprawnych wybiera dla swojego dziecka placówkę ogólnodostępną, zmieniają się rola i zadania przedszkoli, szkół i ośrodków specjalnych. Teraz są to dobrze wyposażone placówki specjalistyczne, zatrudniające profesjonalną kadrę, m.in. pedagogów specjalnych.

W krajach europejskich, niezależnie od tego, w jaki sposób realizowana jest edukacja uczniów z niepełnosprawnościami, rola placówek specjalnych uległa radykalnym zmianom. Ich nowym zadaniem jest wspieranie rodziców, uczniów z niepełnosprawnościami, nauczycieli w przedszkolach i szkołach ogólnodostępnych. W poszczególnych państwach europejskich zakres działań jest różny - od diagnostyki, przez szkolenie kadr, do bezpośredniego wsparcia uczniów. W zależności od polityki danego kraju, placówki specjalne zostały przekształcone w centra zasobów lub centra wsparcia, które - obok prowadzonej wcześniej edukacji - wspomagają szkoły ogólnodostępne.

W 2018 r. Ministerstwo Edukacji Narodowej zwróciło się do Europejskiej Agencji do spraw Specjalnych Potrzeb i Edukacji Włączającej o rekomendacje dotyczące wdrażania w Polsce edukacji włączającej wysokiej jakości, skierowanej do wszystkich uczniów. Agencja poddała analizie przepisy polskiego prawa oświatowego, odbyła debaty ze wszystkimi interesariuszami: niepełnosprawnymi uczniami, rodzicami, nauczycielami, dyrektorami, decydentami. Wynikiem jej pracy jest publikacja Wsparcie podnoszenia jakości edukacji włq̨czajq̨cej 
w Polsce - rekomendacje i działania priorytetowe, w której sformułowano 16 rekomendacji i cztery działania priorytetowe. Rekomendacja $\mathrm{nr} 4$ wskazuje, że: „Polityka edukacyjna powinna nakreślać nową rolę szkół specjalnych i innych placówek specjalistycznych, w ramach której udostępniają one placówkom ogólnodostępnym wiedzę fachową i specjalistyczne zasoby, zwiększając kompetencje kadry kierowniczej i personelu szkół w zakresie rozumienia i wspierania osób uczących się o zróżnicowanych potrzebach edukacyjnych. Oznacza to, że szkoły specjalne powinny wspierać placówki ogólnodostępne, działać jako baza dla multidyscyplinarnych zespołów wsparcia na poziomie lokalnym, co powinno zapewniać równy dostęp do usług w całym kraju".

Z kolei w art. 24 Konwencji o prawach osób niepełnosprawnych („Edukacja”), wskazuje się, że:

"1. Państwa Strony uznają prawo osób niepełnosprawnych do edukacji. W celu realizacji tego prawa bez dyskryminacji i na zasadach równych szans, Państwa Strony zapewnią włączający system kształcenia umożliwiający integrację na wszystkich poziomach edukacji i w kształceniu ustawicznym, zmierzający do:

(a) pełnego rozwoju potencjału oraz poczucia godności i własnej wartości, a także wzmocnienia poszanowania praw człowieka, podstawowych wolności i różnorodności ludzkiej,

(b) rozwijania przez osoby niepełnosprawne ich osobowości, talentów i kreatywności, a także zdolności umysłowych i fizycznych, przy pełnym wykorzystaniu ich możliwości,

(c) umożliwienia osobom niepełnosprawnym efektywnego udziału w wolnym społeczeństwie.

2. Realizując to prawo, Państwa Strony zapewnią, że:

(a) osoby niepełnosprawne nie będą wykluczane z powszechnego systemu edukacji ze względu na niepełnosprawność, a także, że dzieci niepełnosprawne nie będą wykluczane, ze względu na niepełnosprawność, z bezpłatnej i obowiązkowej nauki w szkole podstawowej lub z nauczania na poziomie średnim,

(b) osoby niepełnosprawne będą korzystać z włączającego, bezpłatnego nauczania obowiązkowego wysokiej jakości, 
na poziomie podstawowym i średnim, na zasadzie równości z innymi osobami, w społecznościach, w których żyją,

(c) wprowadzane będą racjonalne usprawnienia, zgodnie z indywidualnymi potrzebami,

(d) osoby niepełnosprawne będą uzyskiwać niezbędne wsparcie, w ramach powszechnego systemu edukacji, celem ułatwienia ich skutecznej edukacji,

(e) stosowane będą skuteczne środki zindywidualizowanego wsparcia w środowisku, które maksymalizuje rozwój edukacyjny i społeczny, zgodnie z celem pełnego włączenia.

3. Państwa Strony umożliwią osobom niepełnosprawnym zdobycie umiejętności życiowych i społecznych, aby ułatwić im pełny i równy udział w edukacji i w życiu społeczności.

W tym celu Państwa Strony będą podejmować odpowiednie środki, w tym:

(a) ułatwianie nauki alfabetu Braille'a, alternatywnego pisma, wspomagających (augmentatywnych) i alternatywnych sposobów, środków i form komunikacji i orientacji oraz umiejętności poruszania się, a także ułatwianie wsparcia rówieśników i doradztwa,

(b) ułatwianie nauki języka migowego i popieranie tożsamości językowej społeczności osób głuchych,

(c) zapewnienie, że edukacja osób, w szczególności dzieci, które są niewidome, głuche lub głuchoniewidome będzie prowadzona w najodpowiedniejszych językach i przy pomocy sposobów i środków komunikacji najodpowiedniejszych dla jednostki, a także w środowisku, które maksymalizuje rozwój edukacyjny i społeczny [...]".

\section{Specjalistyczne Centra Wsparcia Edukacji Włączającej}

Wieloletnie doświadczenia placówek specjalnych w rozpoznawaniu potrzeb szkół ogólnodostępnych pokrywają się z wnioskami formułowanymi podczas debat i konsultacji społecznych, rekomendacjami Agencji oraz z zapisami Konwencji. Jednoznacznie wskazują na konieczność formalnego poszerzenia roli podmiotów tego typu. Podczas prac Zespołu powołanego przez Ministra Edukacji Narodowej w 2017 r. w celu opracowania modelu kształcenia uczniów ze specjalnymi potrzebami edukacyjnymi ustalono, że placówki specjalne powinny zostać 
przekształcone w Specjalistyczne Centra Wspierania Edukacji Włączającej. Miałyby one zachować dotychczasowe zadania związane z prowadzeniem szkół i (lub) oddziałów na każdym etapie edukacyjnym, a jeżeli zajdzie taka potrzeba, to również internatów. Rodzice w Polsce mają prawo wybrać do jakiego typu szkoły/przedszkola mają uczęszczać ich dzieci.

W raporcie Organizacja wsparcia dla edukacji włączajq̨cej z 2014 r. Europejska Agencja do spraw Specjalnych Potrzeb i Edukacji Włączającej podkreślała konieczność utrzymywania wysokiego profesjonalizmu kadry Centrów (s. 14, 25). Do spełnienia tego warunku niezbędne jest ciągłe nabywanie doświadczeń, dlatego $w$ tych jednostkach powinna być prowadzona pełna edukacja, równolegle ze wspieraniem szkół ogólnodostępnych.

Zespół wskazał również możliwość elastycznego przechodzenia uczniów ze szkoły specjalnej do ogólnodostępnej lub odwrotnie. Może to być przydatne w sytuacji, gdy uczeń wymaga pracy w mniej licznym zespole, gdy jego niepełnosprawność i (lub) inne ograniczenia (np. emocjonalne) uniemożliwią mu stałe albo czasowe uczęszczanie do klasy ogólnodostępnej bądź wtedy, gdy w szkole specjalnej opanował niezbędne techniki i posługiwanie się specjalistycznymi pomocami.

Podczas międzynarodowej konferencji dotyczącej kształcenia uczniów z niepełnosprawnościami, która odbyła się w 2014 r. w Łodzi, przedstawiciele Portugalii i Norwegii, czyli państw, w których ok. 20 lat temu zlikwidowano szkoły specjalne, przestrzegali przed takim radykalnym krokiem. Twierdzili, że rolą placówek tego typu powinna być zarówno edukacja, jak i wspomaganie szkół ogólnodostępnych. Z ich doświadczeń wynika, że zawsze pojawią się takie dzieci, które wymagają szkoły specjalistycznej.

W publikacji Europejskiej Agencji do spraw Specjalnych Potrzeb Edukacyjnych i Edukacji Włączającej Organizacja wsparcia dla edukacji włączajq̨cej. Raport podsumowujq̨cy wskazano, że niekorzystne dla dzieci (uczniów) niepełnosprawnych jest tworzenie klas specjalnych w placówkach ogólnodostępnych (Europejska Agencja 2014, s. 9). Edukacja włączająca, zgodnie z rekomendacjami Agencji, powinna zapewniać wysoką jakość kształcenia. Ten cel można osiągnąć przez zaspokojenie potrzeb wszystkich uczniów, tym samym umożliwiając im aktywny udział w procesie nauczania. Przed szkołami ogólnodostępnymi zostało postawione trudne zadanie, jakim jest edukacja dla wszystkich, 
czyli nauczanie i wychowanie zróżnicowanych grup, w tym uczniów z różnymi niepełnosprawnościami.

Jak wspomniano na początku rozdziału, placówki specjalne wspierają szkoły ogólnodostępne od wielu lat i w wielu obszarach. Przed nimi, ale przede wszystkim przed Ministerstwem Edukacji Narodowej, stoi kolejne zadanie - nową rolę placówek specjalnych należy usankcjonować w systemie oświaty, zapewniając na ten cel odpowiednie środki finansowe.

Nowe struktury Centrum mogą być tworzone w placówkach specjalnych. Ponieważ jednak specjalne ośrodki szkolno-wychowawcze dla niepełnosprawnych sensorycznie nie obejmują swoim zasięgiem wszystkich województw, należałoby rozważyć powoływanie Centrów przy innych jednostkach.

\section{Podmiot ubiegający się o pełnienie funkcji Centrum powinien spełniać określone kryteria, m.in.:}

$\rightarrow$ Zatrudniać stały zespół doświadczonych specjalistów i pedagogów specjalnych, a także psychologa, nauczycieli przedmiotów z dodatkowymi kwalifikacjami w zakresie pedagogiki specjalnej, posiadających wiedzę na temat metod i narzędzi, specyficznych technik nauczania, rehabilitantów zajmujących się daną niepełnosprawnością, np. rehabilitanta wzroku, instruktora orientacji przestrzennej, nauczyciela alternatywnych metod komunikacji.

$\rightarrow$ Dysponować bazą lokalową i specjalistyczną (sprzęt i pomoce dydaktyczne), w celu utworzenia wypożyczalni. Bieżące doposażanie oraz wynagrodzenie dla jej pracowników powinno być zaplanowane w budżecie Centrum.

\section{Cele i zadania Specjalistycznego Centrum Wsparcia Edukacji Włączającej}

Centrum będzie oferowało specjalistyczne wsparcie ogólnodostępnym szkołom i przedszkolom, dzieciom z niepełnosprawnością, a także ich rodzinom.

Powinno wspomagać dzieci posiadające orzeczenie o potrzebie kształcenia specjalnego, uczące się w szkołach ogólnodostępnych. Odbywać się to może na wniosek rodzica, szkoły za zgodą rodziców, poradni psychologiczno-pedagogicznej lub innych instytucji (np. pomocy społecznej czy jednostek służby zdrowia). 


\section{Cele}

$\rightarrow \quad$ zwiększenie dostępności do specjalistycznej pomocy rewalidacyjno-rehabilitacyjnej, doradztwa i konsultacji,

$\rightarrow$ stworzenie bezpośredniej możliwości korzystania przez uczniów, rodziców i nauczycieli z porad, konsultacji i informacji udzielanych przez specjalistów,

$\rightarrow$ zapewnienie systematycznej rewalidacji w celu skutecznego wspomagania procesu edukacji ucznia,

$\rightarrow$ wspieranie rodziców i nauczycieli w podnoszeniu ich kompetencji w zakresie wychowania i edukacji dziecka niepełnosprawnego,

$\rightarrow$ monitorowanie przebiegu edukacji i tranzycji na rynek pracy dziecka/ucznia - monitorowanie włączenia społecznego,

$\rightarrow$ ułatwienie dostępu do specjalistycznych pomocy i sprzętów technodydaktycznych.

\section{Zadania}

$\rightarrow$ koordynacja działań Centrum oraz szkoły ogólnodostępnej w zakresie wsparcia, edukacji i rehabilitacji ucznia z niepełnosprawnością i jego rodziny,

$\rightarrow$ dokonywanie wielospecjalistycznej oceny poziomu funkcjonowania dziecka/ucznia, współpraca ze szkołą przy opracowaniu indywidualnego programu edukacyjno-terapeutycznego,

$\rightarrow$ pomoc $\mathrm{w}$ zapewnieniu szkole specjalistycznych pomocy i sprzętów technodydaktycznych, zgodnie z potrzebami (np. wypożyczenie szkole stosownych narzędzi na czas edukacji dziecka lub ich przygotowanie),

$\rightarrow$ wnikliwa obserwacja dziecka w szkole, relacji uczeń - uczeń, uczeń - nauczyciel, wsparcie nauczyciela, w celu budowania prawidłowych relacji,

$\rightarrow$ prowadzenie specjalistycznych i rewalidacyjnych zajęć w zależności od potrzeb (częstotliwość zajęć ustala specjalista w porozumieniu z wychowawcą ucznia i jego rodzicami, opiekunami prawnymi),

$\rightarrow$ wspomaganie nauczycieli w zakresie organizacji miejsca dla ucznia, doboru metod i form pracy - bieżące konsultacje,

$\rightarrow$ prowadzenie szkoleń dla nauczycieli szkół ogólnodostępnych, dotyczących m.in. specyfiki funkcjonowania ucznia niepełnosprawnego; 
$\rightarrow$ pomoc w wyborze dalszego kierunku kształcenia lub typu szkoły oraz w przejściu (tranzycji) na kolejny etap edukacyjny lub na rynek pracy;

$\rightarrow$ podejmowanie działań edukacyjno-informacyjnych dla rodziców - wskazywanie potrzeby tworzenia dla nich grup wsparcia;

$\rightarrow$ współpraca z nauczycielami i rodziną przez cały okres edukacji ucznia;

$\rightarrow$ zapewnienie integracji ze środowiskiem rówieśników z tą samą niepełnosprawnością - budowanie tożsamości rówieśniczej;

$\rightarrow$ organizowanie wspólnych turnusów szkoleniowo-rehabilitacyjnych dla dzieci i rodziców oraz kolonii i obozów (zimowych, letnich) dla osób niepełnosprawnych i ich sprawnych rówieśników;

$\rightarrow$ okresowa ocena efektywności wsparcia udzielanego przez Centrum;

$\rightarrow$ gromadzenie danych dotyczących populacji dzieci/uczniów z niepełnosprawnością, w celu poznania potrzeb wsparcia (liczba uczniów, określenie niepełnosprawności);

$\rightarrow$ opracowywanie materiałów metodyczno-informacyjnych dla szkół, rodziców oraz innych resortów niż edukacyjny (pomoc społeczna, służba zdrowia).

\section{Organizacja i finansowanie}

Pedagodzy specjalni i inni eksperci będą nadal pracownikami placówek specjalnych, poszerzonych o strukturę Centrum. Jest to konieczne w celu zapewnienia bezpieczeństwa zatrudnienia oraz możliwości pracy w zespole multidyscyplinarnym. Pracownicy Centrum będą przenoszeni (np. na zasadach delegacji służbowej) do danej szkoły ogólnodostępnej w określonych dniach w tygodniu, w zależności od liczby uczniów z niepełnosprawnościami i ich potrzeb. Specjalistyczne zajęcia będą mogły być prowadzone w danej szkole ogólnodostępnej i (lub) w Centrum. Wielospecjalistyczna ocena funkcjonowania ucznia, w uzgodnieniu z jego rodzicami, może odbywać się w tej placówce ze względu na zespół specjalistów dokonujący oceny i konieczność korzystania ze specjalistycznego sprzętu. Efektywnym rozwiązaniem byłoby wyposażenie Centrum w samochody i busy ze specjalistycznym sprzętem i z pomocami. Umożliwiłoby to dokonanie oceny i dobranie pomocy bezpośrednio w szkole, do której uczęszcza dany uczeń i (lub) wypożyczenie tej placówce wymaganego sprzętu na czas jego edukacji. 


\section{Warunki osiągnięcia przedstawionych celów i realizacji zadań przez Centrum:}

$\rightarrow$ gotowość do zmiany u dyrektorów i nauczycieli szkół ogólnodostępnych oraz specjalistów z placówek specjalnych, a także decydentów na szczeblu centralnym i lokalnym,

$\rightarrow$ modyfikacja przepisów prawa oświatowego, uwzględnienie Specjalistycznych Centrów Wspierania Edukacji Włączającej jako placówek z podwójnymi zadaniami (edukacja i wspieranie szkół ogólnodostępnych),

$\rightarrow$ opracowanie zasad finansowania delegowanych nauczycieli oraz dodatków za pracę poza Centrum (wysokokwalifikowana kadra);

$\rightarrow$ przygotowanie mechanizmu finansowania zakupu sprzętu do wypożyczalni oraz ewentualnego zatrudnienia dodatkowego pracownika,

$\rightarrow$ opracowanie mechanizmu finansowania procesu przygotowania przez pracowników Centrum specjalistycznych pomocy, np. wydruk w piśmie brajla lub przygotowanie pomocy wypukłych - rysunków, map (środki na materiały i wynagrodzenie). 


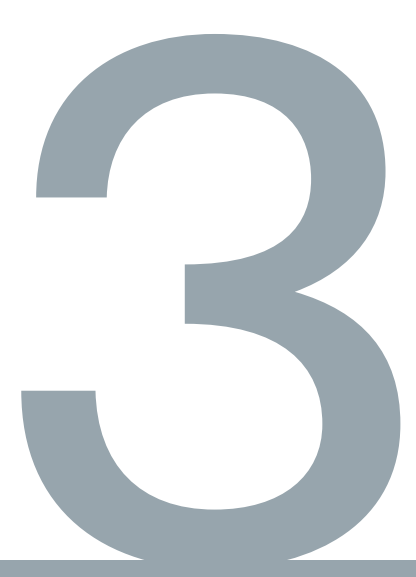


Wspólna przestrzeń

- wspólne problemy

- wspólne rozwiązania.

Doświadczenia praktyków 


\title{
3.1. Różnorodność i inkluzja w edukacji - wybrane aspekty wspierania uczniów z doświadczeniem migracji
}

\author{
Anna Młynarczuk-Sokołowska, Katarzyna Szostak-Król
}

Celem rozdziału jest ukazanie podstawowych zagadnień dotyczących wspierania procesów inkluzji oraz edukacji dzieci z doświadczeniem migracji w ramach edukacji formalnej. Artykuł składa się z dwóch głównych części. Pierwsza poświęcona jest analizie sytuacji dzieci z doświadczeniem migracji, z uwzględnieniem ich szkolnego funkcjonowania. W drugiej zostały zaprezentowane prawne możliwości wspierania imigrantów, uchodźców oraz reemigrantów oraz przykłady dobrych praktyk edukacyjnych w tym zakresie (organizacja oddziałów przygotowawczych, nauczanie języka polskiego jako obcego, realizacja zajęć wyrównawczych itd.).

\section{__ Słowa kluczowe: \\ uczniowie z doświadczeniem migracji \\ inkluzja




\subsection{Diversity and inclusion in education - selected aspects of supporting students with migration experience}

Anna Młynarczuk-Sokołowska, Katarzyna Szostak-Król

The aim of the chapter is to present vital issues related to supporting inclusion and education processes of children with migrant background in the field of formal education. The article consists of two main parts. The first one is devoted to the analysis of student with migrant experience situation including their school functioning. The second one presents legal and methodical possibilities of supporting immigrants, refugees and re-emigrants and examples of good educational practices in this field (welcome classes, teaching Polish as a foreign language, implementation of remedial classes, etc.).

\section{Keywords:}

students with a migrant background

inclusion 
W globalizującym się świecie migrant nie jest już niespotykanym zjawiskiem społeczno-kulturowym, anomalią czy jednostką „egzotyczną" ze względu na kolor skóry, język, którym się posługuje, czy odmienną kulturę. Jego obecność w przestrzeni publicznej zaczyna być (a w wielu środowiskach już jest) czymś naturalnym. Obecnie coraz więcej ludzi, motywowanych różnymi czynnikami, decyduje się na zmianę miejsca zamieszkania. Grupę migrantów tworzą osoby dobrowolnie opuszczające swoje państwo, dla których priorytetem jest poprawa własnej sytuacji ekonomicznej lub osiągnięcie awansu zawodowego w nowym miejscu, a także jednostki wyjeżdzające w obawie o utratę zdrowia lub życia w związku z sytuacją w kraju pochodzenia (problem uchodźstwa). Cechą znamienną dzisiejszych czasów są również reemigracje, wynikające z potrzeby powrotu do domu, porażki migracyjnej czy chęci spędzenia okresu emerytalnego w rodzinnych stronach. W związku z intensyfikacją tych zjawisk migrantami coraz częściej są dzieci.

Zróżnicowanie kulturowe każdego społeczeństwa naturalnie znajduje swoje odzwierciedlenie w placówkach edukacyjnych. Obecnie odbiorcami działań oświatowych są nie tylko członkowie grupy większościowej oraz mniejszości autochtonicznych, ale także nowe kręgi uczniów z doświadczeniem migracji, którzy mają nieraz diametralnie odmienne od większości "kulturowe oprogramowanie" (Hofstede 2010).

\section{Zarys sytuacji dzieci z doświadczeniem migracji}

Grupę uczniów z doświadczeniem migracji w polskim systemie oświaty tworzą najczęściej dzieci imigrantów ekonomicznych, osób, które uzyskały w Polsce status uchodźcy bądź inną formę ochrony prawnej lub ubiegają się o nią, a także reemigrantów. W wielu wypadkach migracje niosą ze sobą duży potencjał edukacyjny, w innych wiążą się z kompletowaniem bagażu trudnych doświadczeń autobiograficznych (Kożyczkowska, Młynarczuk-Sokołowska 2018). Sytuacja uczniów z doświadczeniem migracji jest zróżnicowana i determinowana wieloma czynnikami: specyfiką doświadczeń życiowych, przynależnością kulturową, religijną, statusem społecznym i ekonomicznym, poziomem znajomości języka i kultury polskiej itd. Analiza treści literatury 
przedmiotu oraz nasze doświadczenia wynikające z wieloletniej pracy w środowisku zróżnicowanym kulturowo pokazują, że często inaczej przebiegają procesy inkluzji i edukacji dzieci imigrantów zarobkowych (np. ukraińskich) i reemigrantów niż dzieci uchodźców (np. z Czeczenii), którzy wraz z rodzicami opuścili swoją ojczyznę w obawie o utratę życia, zdrowia lub bezpieczeństwa. Dzieje się tak zwłaszcza wtedy, gdy mają oni trudne doświadczenia i różnią się znacznie od członków społeczeństwa przyjmującego w zakresie kulturowym i religijnym, posługiwania się językiem polskim oraz znajomością polskiej kultury (Młynarczyk-Sokołowska, Szostak-Król 2016). Niejednokrotnie efektywność pracy z osobami z doświadczeniem migracji oraz heterogenicznym zespołem zależy od dodatkowego wsparcia udzielonego poszczególnym uczniom $w$ formie np. pomocy psychologicznej, nadprogramowej nauki języka polskiego jako obcego, zajęć wyrównawczych.

Realizacja modelu edukacji inkluzyjnej, umożliwiającej efektywną pracę z dziećmi z doświadczeniem migracji oraz grupą zróżnicowaną kulturowo, jest wielkim wyzwaniem stojącym przed edukacją w Polsce $i$ w innych krajach europejskich. Temat ten był niejednokrotnie szeroko dyskutowany na szczeblu międzynarodowym. Zgodnie z treścią konkluzji Rady Europy w sprawie kształcenia dzieci ze środowisk migracyjnych, edukacja ma się istotnie przyczyniać do ich udanej integracji w społeczeństwach europejskich. Wobec tego państwa członkowskie zobowiązane są do zastosowania odpowiednich środków (na szczeblu lokalnym, regionalnym lub krajowym) w celu zapewnienia wszystkim dzieciom równych szans oraz wsparcia niezbędnego do pełnego rozwoju ich potencjałów, niezależnie od tego, z jakich środowisk pochodzą (Council Conclusions of 26 November 2009).

Mimo wielu modelowych działań podejmowanych w polskich placówkach edukacyjnych efektywna praca z imigrantami, uchodźcami i reemigrantami oraz z grupą zróżnicowaną kulturowo wymaga projektowania przemyślanych rozwiązań systemowych (i doskonalenia już istniejących), a także międzykulturowej metodyki, uwzględniającej ustawiczne diagnozowanie potrzeb wszystkich uczestników procesu uczenia się, bez względu na przynależność narodową, wyznawaną religię czy sytuację życiową. Osoby z doświadczeniem migracji to często 
uczniowie ze specjalnymi potrzebami edukacyjnymi ${ }^{2}$, dla których niezbędna jest m.in. indywidualizacja procesu kształcenia.

Polskie prawo umożliwia dostęp do powszechnego systemu oświaty każdemu dziecku przebywającemu na terenie kraju - bez względu na jego status prawny. Gwarancję uczestnictwa w edukacji dzieci migrantów stanowi art. 70 Konstytucji Rzeczypospolitej Polskiej. Podstawy nieodpłatnego kształcenia cudzoziemców oraz podejmowania działań służących inkluzji w procesie edukacji regulują zapisy ustawy Prawo oświatowe z dnia 16 grudnia 2016 r. i Rozporządzenia Ministra Edukacji Narodowej z dnia 23 sierpnia 2017 r. w sprawie kształcenia osób niebędących obywatelami polskimi oraz osób będących obywatelami polskimi, które pobierały naukę w szkołach funkcjonujących w systemach oświaty innych państw.

Rozpoczęcie edukacji w nowym kraju zamieszkania lub powrót do systemu edukacyjnego państwa pochodzenia (reemigracje) wymaga od dzieci zaadaptowania się do nowych realiów, z którymi wiążą się inne niż dotychczas oczekiwania. Uczniowie z doświadczeniem migracji, szczególnie uchodźstwa, mogą borykać się z wieloma problemami utrudniającymi proces adaptacji w systemie edukacyjnym. Pierwszą barierą, z którą się stykają się osoby pochodzące z innych krajów, a także często reemigranci, jest nieznajomość lub słaba znajomość urzędowego języka komunikacji. Rozwijanie kompetencji komunikacyjnych w zakresie porozumiewania się w języku polskim jest pierwszoplanowym czynnikiem aktywnej partycypacji w edukacji szkolnej. Bariera językowa powoduje nie tylko utrudnienia w codziennym porozumiewaniu się, ale także kłopoty ze zrozumieniem tekstów pisanych i poleceń w języku polskim (Młynarczuk-Sokołowska, Szostak-Król 2016).

Zdarza się, że migranci w początkowym okresie pobytu w Polsce przeżywają szok kulturowy (Boski 1998) bądź powrotny szok kulturowy (reemigranci) ${ }^{3}$ (Grzymała-Moszczyńska 2015). Ten pierwszy jest tym bardziej odczuwalny, im większe są różnice między kulturą oraz językiem macierzystego kraju a nowego, do którego trafiają cudzoziemcy. Powrotny szok kulturowy wiąże się z kolei ze zmianami zachodzącymi organizacji i udzielania pomocy psychologiczno-pedagogicznej w publicznych przedszkolach, szkołach i placówkach (Dz.U. z 2017 r. poz. 1591), par. 2, pkt 1-3. 
w przestrzeni społeczno-kulturowej państwa pochodzenia w okresie nieobecności migranta, a także tymi w jego tożsamości (Barzykowski, Grzymała-Moszczyńska i in. 2013).

Proces wchodzenia w krąg odmiennej rzeczywistości społeczno-kulturowej (akulturacja) dotyczy również dzieci (Borkowska 2016). Jest długotrwały $i$ wiąże się z ustawicznym gromadzeniem nowych, nieraz bardzo trudnych doświadczeń, na wszystkich płaszczyznach aktywności ludzkiej. Dzieciom uchodźców proces akulturacji utrudniają traumatyczne przeżycia z kraju pochodzenia. Mogą być one przyczyną zarówno wycofania, apatii, zamknięcia się w sobie, jak i nadpobudliwości oraz zachowań agresywnych. Akulturacja może przybierać wiele form i przynieść różne skutki. Wiąże się ze zmianami w systemie wartości, zachowaniach oraz w tożsamości. Omawiany proces może kończyć się integracją, asymilacją, separacją bądź marginalizacją. Optymalną strategią akulturacji jest integracja, będąca wynikiem spotkania i dialogu między kulturą kraju przybyszów i kraju przyjmującego (Berry 1998).

Sprzeczności wynikające z wyznawanych wartości, przyjętych norm kulturowych oraz złożona tożsamość kulturowa sprawiają, że dzieciom z doświadczeniem migracji nie jest łatwo wejść w nową rzeczywistość szkolną. Zdarza się, że odmienność kulturowa i nakładające się na nią niskie kompetencje (bądź ich brak) w zakresie porozumienia się w języku polskim powodują, że są one izolowane od grup rówieśniczych. By zaaklimatyzować się w nowej szkole, potrzebują życzliwości ze strony rówieśników oraz kadry pedagogicznej, a także wsparcia dopasowanego do ich indywidualnych, zdiagnozowanych potrzeb.

\section{Ku inkluzji dzieci z doświadczeniem migracji - aspekty prawne i metodyczne}

Inkluzja i postępy edukacyjne uczniów z doświadczeniem migracji są w dużej mierze warunkowane możliwościami, które stwarza im szkoła. Dlatego kadra pedagogiczna powinna dysponować kompetencjami niezbędnymi do pracy w środowisku zróżnicowanym kulturowo oraz znać prawne możliwości wspierania uczniów tego typu w trakcie edukacji szkolnej.

Praca w warunkach zróżnicowania kulturowego jest nieprzewidywalna oraz stwarza wiele wyzwań. Wymaga od nauczycieli otwartych postaw, rozległej wiedzy oraz wielu umiejętności. Nie istnieje uniwersalny model programowy i metodyczny, który umożliwiłby radzenie sobie we 
wszystkich sytuacjach pojawiających się na stykach kultur. W dynamicznie zmieniającej się rzeczywistości społeczno-kulturowej trudno uzyskać wykształcenie, które można uznać za wystarczające. Kompetencje osób zaangażowanych w praktykę edukacyjną (w tym międzykulturową) powinny być ustawicznie rozwijane - zarówno w ramach procesu uczenia się przez całe życie, samokształcenia, w dialogowej relacji nabywania wiedzy teoretycznej, jak i przez praktyczne doświadczenia. Niezwykle ważna jest w tej sytuacji gotowość do realizacji edukacji w środowisku międzykulturowym (Lewowicki 2008) i tym samym korzystania z potencjału istniejącego w grupach zróżnicowanych, z którymi pracują pedagodzy i nauczyciele, oraz poszukiwania własnych, wrażliwych kulturowo, rozwiązań metodycznych. Trzeba pamiętać, że to nauczyciele i edukatorzy najczęściej wprowadzają uczniów w polskie realia i dziedzictwo, a także w skomplikowane zagadnienia międzykulturowe (różnice, komunikacja itp.). Rozpoczęcie pracy ze środowiskami migracyjnymi i z grupą zróżnicowaną kulturowo daje możliwość wyjścia poza rodzimą perspektywę postrzegania świata oraz monokulturową metodykę działania.

Efektywna praca z uczniami z doświadczeniem migracji w grupie zróżnicowanej kulturowo wymaga projektowania procesu edukacyjnego na podstawie rozpoznania wymagań poszczególnych uczniów. Uwzględnianie specjalnych potrzeb edukacyjnych imigrantów, uchodźców i reemigrantów (a także innych grup uczniów) wiąże się z koniecznością indywidualizowania treści kształcenia, wymogów szkolnych oraz procesu oceniania cząstkowego i końcowego. Powstaje zatem pytanie: jak efektywnie realizować zajęcia przedmiotowe w grupie o zróżnicowanych potrzebach edukacyjnych?

Jedną ze sprawdzonych metod $w$ tym zakresie jest preparowanie tekstów, które polega na leksykalnym i gramatycznym upraszczaniu treści przewidzianych w programach kształcenia i projektowaniu zadań dydaktycznych nawiązujących bezpośrednio do zmodyfikowanych materiałów (Bernacka-Langier, Janik-Płocińska i in. 2010). Dzięki zastosowaniu tej metody wszyscy uczniowie równolegle mogą realizować treści kształcenia zgodnie ze swoimi możliwościami. W tym wypadku, w celu zachowania zadowalającej dynamiki pracy, niezbędne jest również wsparcie nauczyciela oraz uczniów przez innego pedagoga lub asystenta międzykulturowego.

Zgodnie z obowiązującym w Polsce prawem uczniowie z doświadczaniem migracji mają możliwość nauki w tzw. oddziałach przygo- 
towawczych (welcome class) ${ }^{4}$, co umożliwia realizację programów kształcenia przez jeden rok szkolny (bądź okres krótszy lub dłuższy, w zależności od potrzeb) w małej grupie, liczącej maksymalnie 15 osób, zgodnie $z$ ich indywidualnymi wymaganiami rozwojowymi i edukacyjnymi. Mogą także skorzystać z dodatkowych lekcji języka polskiego jako obcego. Podstawą procesu edukacji w oddziałach przygotowawczych powinna więc być indywidualizacja treści kształcenia, wymagań szkolnych oraz sposobu oceniania cząstkowego i końcowego, dostosowana do kompetencji (także językowych) ucznia.

W Szkole Podstawowej nr 221 w Warszawie funkcjonuje aż pięć oddziałów przygotowawczych, w których uczą się dzieci począwszy od wieku wczesnoszkolnego, na gimnazjum kończąc. W klasach tych znajdują się uczniowie z doświadczeniem migracji z różnych zakątków świata (Ukraina, Indie, Wietnam, Tadżykistan, Irak i Azerbejdżan).

Niezależnie od tego, czy w szkole zostanie utworzony taki oddział czy nie, uczniowie z doświadczeniem migracji mają prawo do dodatkowej nauki języka polskiego ${ }^{5}$ (w wymiarze nie niższym niż dwie godziny lekcyjne tygodniowo), którą organizuje organ prowadzący placówkę (na wniosek dyrektora). Zajęcia prowadzone są w formie lektoratu z języka polskiego jako obcego, a ich zadaniem jest intensywne rozwijanie kompetencji lingwistycznych słuchaczy. Skuteczność tych lekcji zależy od regularnego udziału dzieci. $Z$ naszych doświadczeń wynika, że motywację i frekwencję w dużej mierze warunkują metody i formy pracy stosowane przez nauczyciela. Ważne jest zatem, aby uwzględniały one indywidualne potrzeby rozwojowe i edukacyjne uczniów.

W trakcie zajęć z języka polskiego jako obcego może być stosowana m.in. metoda międzykulturowego portfolio. Polega ona na systematycznym dokumentowaniu przez uczniów rozwoju ich umiejętności językowych oraz doświadczeń międzykulturowych w formie prac, gromadzonych w specjalnie przygotowanej teczce lub segregatorze. Ważnym elementem tej metody jest monitorowanie i ewaluowanie ust. 11-14; Rozporządzenie Ministra Edukacji Narodowej z dnia 23 sierpnia 2017 r. w sprawie kształcenia osób niebędących obywatelami polskimi oraz osób będących obywatelami polskimi, które pobierały naukę w szkołach funkcjonujących w systemach oświaty innych państw (Dz.U. z 2017 r. poz. 1655), par. 16, ust. 1-9. 
własnych postępów w nauce języka oraz w zakresie rozwijania międzykulturowych kompetencji komunikacyjnych (Młynarczuk-Sokołowska, Szostak-Król 2016).

Niezwykle istotne jest także wspieranie uczniów w zakresie wyrównywania zaległości edukacyjnych, tak aby zapobiegać pogłębianiu się trudności, drugoroczności oraz ekskluzji edukacyjnej i społecznej. Nasze obserwacje wskazują, że wielu uczniów z doświadczeniem migracji nie byłoby $w$ stanie poradzić sobie $z$ realizacją podstawy programowej, gdyby nie uczestniczyło w spotkaniach wyrównawczych z wybranych przedmiotów. Prawodawstwo stwarza możliwość prowadzenia zajęć wyrównawczych ${ }^{6} \mathrm{z}$ różnych przedmiotów, w wymiarze jednej godziny tygodniowo. Organizuje je organ prowadzący szkołę w sytuacji, gdy nauczyciel prowadzący zajęcia edukacyjne $z$ danego przedmiotu stwierdzi konieczność uzupełnienia różnic programowych przez ucznia z zagranicy.

Cudzoziemcy podejmujący naukę w szkole mają prawo do korzystania ze wsparcia osoby władającej językiem ich kraju pochodzenia, zatrudnionej w charakterze pomocy nauczyciela, nazywanej często asystentem międzykulturowym ${ }^{7}$. Placówka, w której znajdują się uczniowie z zagranicy, może wnioskować do organu prowadzącego o tego typu osobę. Obowiązki asystentów polegają na wielozakresowym wspieraniu zarówno uczniów (lingwistycznym, kulturowym, mediacyjnym itp.), jak i innych członków społeczności szkolnej oraz kadry pedagogicznej. Powinni oni przede wszystkim wspomagać dzieci językowo w początkowym okresie nauki w nowej szkole, brać udział w lekcjach (i np. wyjaśniać podopiecznym treści poleceń), towarzyszyć w odrabianiu prac domowych. Istotne jest również zapewnianie dzieciom poczucia bezpieczeństwa, ułatwienie im adaptacji w nowym środowisku szkolnym, m.in. przez przybliżanie nowego systemu pracy ( $w$ tym zasad i obowiązków) oraz motywowanie do partycypacji w życiu placówki. Częścią pracy asystenta jest także współpraca z rodzicami.

Ważnym czynnikiem inkluzji cudzoziemców jest ich znajomość języka ojczystego oraz rodzimej kultury i religii. Braki w tym zakresie mogą stanowić znaczną barierę w dostosowywaniu się do realiów nokształcenia osób niebędących obywatelami polskimi..., par. 18 ust. 1-3. 
wego kraju. Dlatego warto korzystać z możliwości organizowania cudzoziemcom nauki języka i kultury kraju pochodzenia ${ }^{8}$. Zajęcia w tym zakresie są najczęściej inicjowane przez organizacje pozarządowe w porozumieniu z dyrektorem szkoły i za zgodą organu prowadzącego placówkę.

Poza wskazanymi wcześniej formami wsparcia uczniowie cudzoziemscy mają także prawo do nauki religii ${ }^{9}$.

\section{Zakończenie}

Jednym z priorytetów współczesnej edukacji jest rozwiązanie kwestii przygotowania uczniów z doświadczeniem migracji do pełnej partycypacji w życiu szkoły oraz całego społeczeństwa. Imigranci, uchodźcy oraz reemigranci, rozpoczynając naukę w polskich placówkach edukacyjnych, potrzebują niejednokrotnie wielopłaszczyznowego wsparcia, w związku z tym niezbędne jest systematyczne rozpoznawanie ich potrzeb. Bardzo ważnym czynnikiem efektywnej inkluzji i edukacji dzieci z doświadczeniem migracji jest odpowiednie przygotowanie kadry pedagogicznej. Oznacza to posiadanie przez nauczycieli kompetencji niezbędnych do pracy z tą grupą uczniów, znajomości prawnych możliwości ich wspierania (oddziały przygotowawcze, zajęcia z języka polskiego jako obcego, lekcje wyrównawcze itp.) oraz umiejętności działania z zespołem zróżnicowanym kulturowo. Nasze doświadczenia pokazują, że niezykle istotne są postawy otwarte, dostrzegające potencjał takich grup. Obecność dzieci z doświadczeniem migracji w przestrzeni edukacyjnej powinna być dla pedagogów, nauczycieli oraz ich szkolnych kolegów szansą, a nie obciążeniem. Umożliwia zaznajomienie się z innymi kulturami i językami, rozbudzenie ciekawości poznawczej, otwarcie się na bogactwo różnorodności i w tym kontekście rozwijanie własnej tożsamości. Stwarza także okazję do ciągłego kształcenia kompetencji międzykulturowych i uczenia się pokojowego koegzystowania w zróżnicowanym społeczeństwie. kształcenia osób niebędących obywatelami polskimi..., par. 20 ust. 1-3. 


\title{
3.2. Nie marnujmy talentów! Wspieranie uczniów zdolnych w praktyce edukacyjnej
}

\author{
Tomasz Knopik
}

Celem artykułu jest prezentacja idei całościowego wspomagania rozwoju uczniów zdolnych w praktyce szkolnej. Na podstawie modelu GROW (G - grupa, R - równowaga, O - osiągnięcia, W - wsparcie) wskazano kluczowe kierunki działań służące aktualizacji zdolności. Ich wspólnym aspektem jest tworzenie warunków sprzyjających ujawnieniu się, docenieniu i rozwinięciu zdolności oraz uzdolnień u jak największej liczby uczniów. Taka strategia wspomagania osób zdolnych wpisuje się bezpośrednio w ideę edukacji włączającej jako nauczania wysokiej jakości dla wszystkich uczniów.

\section{__ Słowa kluczowe:}

\section{zdolności}




\title{
3.2. Don't waste talent! \\ Supporting gifted students in educational practice
}

\author{
Tomasz Knopik
}

The aim of this article is to present the idea of comprehensive support for the development of gifted students in school practice. Based on the GROW model (acronym in Polish: G - group, R-balance, $\mathrm{O}$ - achievements, $\mathrm{W}$ - support), the key directions of actions for updating the abilities were indicated. Their common aspect is to create a context conducive to revealing, appreciating and developing the abilities and talents of many students as possible. Such a strategy of supporting gifted people as directly contributes to the idea of inclusive education as high-quality education for all students.

\section{_ Keywords:}

\section{abilities}




\section{Uczeń zdolny i jego zróżnicowane potrzeby - anekumena polskiej edukacji?}

Uczniowie zdolni włączeni są do grupy osób ze specjalnymi potrzebami edukacyjnymi (SPE) ${ }^{1}$, co oznacza, że system oświaty powinien zapewniać im odpowiednie wsparcie - w zakresie zarówno identyfikacji potencjału, jak i jego aktualizacji. Praktyka pokazuje jednak, że większość tego rodzaju uczniów nie otrzymuje właściwej pomocy, z czego około połowa w ogóle nie zostaje zdiagnozowana jako osoby ponadprzeciętne. Prowadzi to do sytuacji, w której szkoła nie pełni funkcji miejsca odkrywania talentów, a czasem wręcz odwrotnie - przyczynia się do ich marnowania. Dochodzi do tego na skutek wielu przyczyn, z których najczęstsze to:

$\rightarrow$ skupianie się przez nauczycieli na realizacji podstawy programowej, która określa minimalny poziom efektów uczenia się, co nie sprzyja tworzeniu wykraczających poza standardy sytuacji dydaktycznych;

$\rightarrow$ funkcjonowanie fałszywego stereotypu, że uczniowie zdolni nie wymagają specjalnego wsparcia ze względu na ich ponadprzeciętny potencjał ("zdolny i tak sobie poradzi");

$\rightarrow$ niedostrzeganie potencjału uczniów ze względu na ich trudne zachowanie (przeszkadzanie podczas lekcji, arogancja, agresja werbalna, czasem fizyczna, nadaktywność - symptomy frustracji poznawczej znudzonego i mającego poczucie niezrozumienia ucznia zdolnego interpretowane są jako działania aspołeczne, niewpisujące się w etykietę "zdolnego i grzecznego");

$\rightarrow$ redukowanie uzdolnień uczniów do zakresu przedmiotów szkolnych (nauczyciele poszukują talentów matematycznych, polonistycznych lub plastycznych, podczas gdy paleta możliwości jest znacznie szersza i obejmuje np. umiejętności graficzne, geometryczne - jako dziedziny matematyki lub ekonomiczne);

$\rightarrow$ koncentrowanie uwagi jedynie na potrzebach poznawczych uczniów zdolnych bez uwzględnienia pozostałych komponentów psychicznych warunkujących rozwój potencjału (m.in. twórczość, zaangażowanie zadaniowe, relacje społeczne). 
Zrozumienie istoty zróżnicowanych potrzeb uczniów zdolnych wymaga odpowiedzi na pytanie o to, kim w ogóle jest uczeń zdolny. Na tej podstawie można wskazać kryteria diagnostyczne, które decydują o nominacji nauczycielskiej (identyfikacji, kto jest zdolny). Sami nauczyciele dysponują ponad dwudziestoma różnymi definicjami zdolności (Knopik 2018), co przekłada się na odmienne strategie i decyzje identyfikacyjne. Na podstawie krytycznej analizy literatury przedmiotu w niniejszym tekście wprowadzę następującą terminologię:

a. uczeń zdolny - osoba z ponadprzeciętnym ogólnym potencjałem poznawczym stanowiącym podstawę rozwiązywania problemów w poszczególnych obszarach; najczęstszym wskaźnikiem zdolności jest iloraz inteligencji (stąd w wypadku inteligencji powyżej przeciętnej - IQ>115 - można mówić o uczniu zdolnym, w wypadku inteligencji powyżej 130 - o wybitnie zdolnym, co dotyczy ok. $2 \%$ populacji);

b. uczeń uzdolniony - osoba wykorzystująca swój ponadprzeciętny ogólny potencjał poznawczy w konkretnej dziedzinie, np. muzyce, literaturze, informatyce (stąd uzdolnienia muzyczne, literackie lub informatyczne);

c. uczeń utalentowany - często określenie to traktowane jest jako ekwiwalent terminu "uczeń uzdolniony", można jednak doprecyzować je przez wskazanie poziomu rozwoju uzdolnień - talent jest rozwinięciem uzdolnień, wiąże się z osiągnięciami, z wymiernymi wskaźnikami (nagrody, publikacje, pasje, oryginalne pomysły itp.);

d. zdolności - w ujęciu komponentowym to wynik interakcji między inteligencją (percepcja, pamięć, uwaga, myślenie, wyobraźnia), twórczością (płynność i oryginalność myślenia, otwartość na zmiany, tolerancja ryzyka poznawczego) a motywacją (zainteresowania, pracowitość, tolerancja porażek); zdolności tworzą się zatem i rozwijają na skutek wzajemnego oddziaływania tych trzech komponentów, a troska o uwzględnienie tego założenia zarówno na etapie ich identyfikacji, jak i stymulowania powinna stanowić podstawę kompetentnego wspierania uczniów zdolnych (por. Renzulli 2003).

Swoistym przełomem w międzynarodowym dyskursie wokół zdolności były publikacje Roberta Sternberga, który podważył wcześniejsze, (według niego zbyt optymistyczne) ustalenia psychologów dotyczące 
roli poziomu inteligencji w osiąganiu sukcesu życiowego. Sternberg, analizując biografie wielu wybitnych ludzi, doszedł do wniosku, że sama inteligencja analityczna nie jest wystarczająca (Sternberg 1996). Powinna być ona wsparta inteligencją twórczą oraz praktyczną. Tylko wtedy, dzięki synergii między tymi trzema typami zdolności możliwe jest skuteczne rozwiązywanie problemów z obszaru tzw. pragmatyki życiowej, opracowywanie nowych, niestandardowych strategii działania, a co najbardziej istotne - czerpanie satysfakcji z własnego życia. Sternberg zwrócił zatem uwagę na właściwą funkcję inteligencji, czyli optymalne przystosowanie służące szczęściu człowieka. Wyższa inteligencja zatem powinna wiązać się z lepszą adaptacją, a co za tym idzie - z większym dobrostanem. Niestety, w rzeczywistości zbyt często ponadprzeciętny potencjał związany jest z problemami emocjonalnymi, dystymią, a nawet depresją, zaburzeniami psychicznymi oraz dojmującym poczuciem osamotnienia (Sękowski 2001). Może to oznaczać, że osoba zdolna nie otrzymała odpowiedniego wsparcia w procesie aktualizacji własnego potencjału, a same zdolności, zamiast być katalizatorem rozwoju, pełniły funkcję balastu.

\section{Model wspomagania rozwoju uczniów zdolnych - GROW}

Odwołując się bogatej literatury na temat strategii aktualizacji potencjału uczniów zdolnych (Sękowski 2001; Limont 2011; Pfeiffer i in. 2018) warto wyróżnić cztery kluczowe obszary wsparcia GROW: G - grupa, R - równowaga, O - osiągnięcia, W - wsparcie (rys. 1).

Pierwszy z nich wskazuje na konieczność zorganizowania dla uczniów zdolnych grupy odniesienia, stanowiącej optymalną przestrzeń rozwoju zarówno poznawczego, jak i emocjonalno-społecznego. Pojedynczy uczniowie zdolni w klasie muszą bardzo często zmierzyć się z dylematem: pozostać sobą czy "na siłę" upodobnić się do innych. Oryginalność, przejawiająca się m.in. specyficznym poczuciem humoru, specjalistycznymi zainteresowaniami czy nasiloną ciekawością poznawczą, skazuje ich na indywidualizm, a nawet wyalienowanie. Chcąc przynależeć do grupy, celowo ograniczają swoje niekonwencjonalne zachowania, co hamuje rozwój zarówno ich zdolności, jak i osobowości (rezygnacja podmiotu z kluczowych wartości). Dlatego tak istotnym zadaniem szkoły jest stworzenie każdemu uczniowi zdolnemu odpowiedniego środowiska rówieśniczego, w którym nie będzie musiał wchodzić w rolę kogoś innego, niż naprawdę jest. Ponadto współpraca 
z innymi zdolnymi rówieśnikami stymuluje ich wszechstronny rozwój, dając szansę na osiągnięcie synergii i poradzenie sobie z wyzwaniami, z którymi pojedynczy umysł nie miałaby szans się zmierzyć. Wspólne (a nie osamotnione - jak najczęściej bywa w rzeczywistości szkolnej) rozwiązywanie problemów to jedna z najbardziej efektywnych strategii aktualizacji potencjału uczniów ponadprzeciętnych (Knopik 2018).

Rysunek 1. Model GROW - cztery kluczowe obszary wspierania ucznia zdolnego

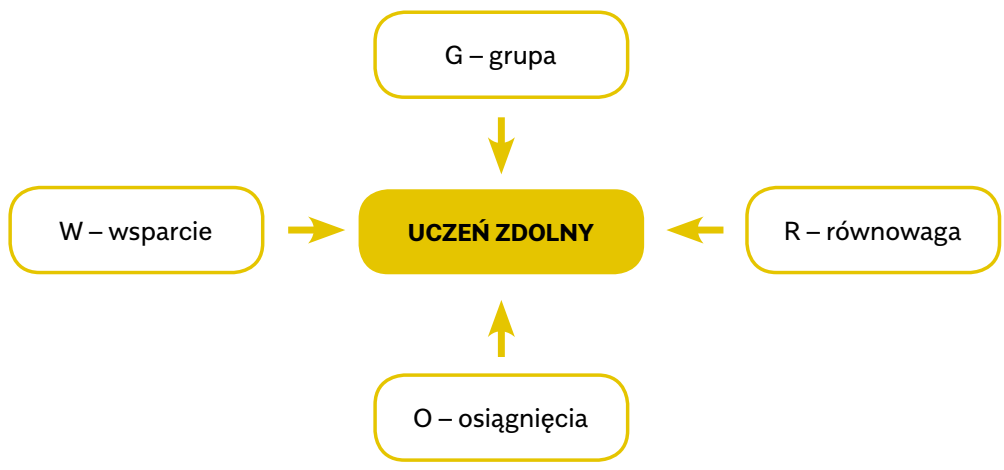

Źródło: Opracowanie własne.

Równowaga wskazuje na konieczność wspierania nie tylko rozwoju poznawczego uczniów zdolnych, ale także pozostałych sfer (osobowość, obszar emocjonalno-motywacyjny, relacje społeczne, sprawność ruchowa, orientacja aksjologiczna, kreatywność), równie istotnych dla wykorzystania posiadanego potencjału w procesie optymalnej adaptacji życiowej. Zdecydowana większość działań rodziców i nauczycieli skupia się na poszerzaniu wiedzy swoich uzdolnionych dzieci, co - jak wskazuje praktyka - nie wystarcza do osiągnięcia sukcesu (określonego przez Sternberga w jednej z teorii inteligencji jako "powodzenie życiowe"). Brak równowagi wynikający ze zbyt wczesnej i zbyt intensywnej stymulacji poznawczej dzieci może również przejawiać się w ich asynchronii rozwojowej, manifestującej się m.in. niestabilnością i nadwrażliwością emocjonalną (asynchronia w aspekcie afektywnym), niezbornością ruchową (asynchronia w aspekcie motorycznym) czy osamotnieniem (asynchronia w aspekcie społecznym). 
Trzecim obszarem są osiągnięcia, stanowiące ważną informację dla uczniów zdolnych w procesie budowania obrazu siebie, a więc samowiedzy i samooceny. Sukcesy i porażki pozwalają określić im mocne oraz słabe strony, a na tej podstawie adekwatnie skonstruować ścieżkę własnego rozwoju (co jest szczególnie ważne, biorąc pod uwagę zjawisko posiadania przez uczniów zdolnych wielu zainteresowań). Osiągnięcia pełnią istotną funkcję w budowaniu trwałej motywacji do rozwijania swoich zdolności - powinny one jednak być rozpatrywane w perspektywie zarówno nagród zewnętrznych (np. laury w konkursach, olimpiadach), jak i wewnętrznych gratyfikacji (transgresje - przekraczanie własnych granic) (por. Kozielecki 2007).

Ostatni obszar - wsparcie - dotyczy czynników środowiskowych niezbędnych do rozwijania uzdolnień uczniów. Można wśród nich wymienić zasoby:

$\rightarrow$ ludzkie (dostęp do ekspertów z danej dziedziny, wsparcie psychologiczne, pomoc ze strony nauczycieli, rodziców);

$\rightarrow$ materialne (profesjonalny sprzęt, specjalistyczne oprogramowanie, instrumenty muzyczne, dostęp do dobrze wyposażonych bibliotek);

$\rightarrow$ organizacyjne (realizacja przez szkoły systemowych rozwiązań w zakresie wspierania zdolności, kultura uczenia się danej szkoły sprzyjająca rozwojowi uczniów zdolnych, dostęp do organizacji specjalizujących się w udzielaniu pomocy grupie uczniów ze specjalnymi potrzebami edukacyjnymi, regionalne programy wsparcia).

Wymienione obszary nie wyczerpują wszystkich potrzeb uczniów zdolnych - wskazują jednak główne kierunki działań pomocowych, ułatwiających tworzenie przez szkoły własnych programów wspomagania rozwoju talentów z wykorzystaniem lokalnych zasobów i po uwzględnieniu specyfiki danego środowiska (np. poziom współpracy z rodzicami, popularność inicjatyw międzyszkolnych, otwartość na zmiany).

\section{Dobre praktyki - GROW w dzialaniu}

W tabelach poniżej zamieszczono przykładowe rozwiązania realizujące kierunki wsparcia opisane w modelu GROW. Należy pamiętać, że o efektywności udzielanej pomocy decyduje jej całościowy charakter, stąd tak ważne jest uwzględnienie w projektowanych działaniach wszystkich czterech obszarów. 
Obszar: GRUPA

\begin{tabular}{l|l}
\multicolumn{1}{c|}{ TYP DZIAtANIA } & \multicolumn{1}{c}{ OPIS DzıAŁANIA } \\
\hline $\begin{array}{l}\text { Międzyklasowe } \\
\text { lub międzyszkolne } \\
\text { koła zainteresowań }\end{array}$ & $\begin{array}{l}\text { Działania te pozwalają wyodrębnić grupy uczniów na podobnym poziomie uzdol- } \\
\text { nień, co umożliwiłoby ich wzajemną stymulację. Często koła zainteresowań } \\
\text { dla danej klasy nie pełnią rozwijającej i integrującej funkcji ze względu na ponow- } \\
\text { ne osamotnienie ucznia zdolnego (podobnie jak podczas zajęć programowych). }\end{array}$ \\
\hline Obozy naukowe & $\begin{array}{l}\text { Interdyscyplinarne kilkudniowe spotkania są okazją do dzielenia się z innymi } \\
\text { uczniami zdolnymi swoimi obecnymi zainteresowanymi i osiągnięciami, } \\
\text { np. w ramach badania danego zjawiska przyrodniczego. Ponadto, obozy rozwijają } \\
\text { kompetencje społeczne, pozwalają uczestnikom przewartościować swoje do- } \\
\text { tychczasowe myślenie o sobie (np. postrzeganie siebie jako dziwaka) i z zupełnie } \\
\text { innym nastawieniem powrócić do szkoły. }\end{array}$ \\
\hline $\begin{array}{l}\text { Zespoły zadaniowe } \\
\text { (projektowe) }\end{array}$ & $\begin{array}{l}\text { Mogą powstawać w ramach jednej klasy, szkoły lub sieci szkół np. w danym } \\
\text { mieście. Członkowie grupy, zgodnie z ideą projektu, sami formułują interesujące } \\
\text { ich problemy badawcze i opracowują strategię poszukiwania na nie odpowiedzi. } \\
\text { Ważnym wsparciem dla zespołów zadaniowych są eksperci - nauczyciele } \\
\text { lub osoby z zewnętrz (np. naukowcy, pracownicy przedsiębiorstw). }\end{array}$
\end{tabular}

Obszar: RÓWNOWAGA

TYP DZIAŁANIA

Zachęcanie uczniów zdolnych do aktywności fizycznej

\section{OPIS DZIAKANIA}

Uczniowie zdolni często unikają zajęć sportowych, dlatego że preferują te aktywności, w których mogą być co najmniej dobrzy (w konfrontacji z rówieśnikami). Stąd ważna jest zachęta do podejmowania tego typu działań przez umiejętne łączenie ćwiczeń fizycznych z wysiłkiem poznawczym. Na przykład: Matematyczna Liga Futbolowa (dostęp do dodatkowych rzutów karnych warunkowany jest poprawnym rozwiązaniem zadania przez drużynę lub pojedynczego zawodnika, gol premiowany dodatkowym punktem, możliwość anulowania gola pod warunkiem podania rozwiązania zagadki matematycznej), maraton historyczny (bieg z zagadkami historycznymi - warunkiem zaliczenia całej trasy jest znalezienie rozmieszczonych w różnych punktach zagadek oraz ich rozwiązanie). Warto dodać, że tego typu ćwiczenia motywują również do aktywności poznawczej tych uczniów, którzy zazwyczaj lepiej radzą sobie z wysiłkiem fizycznym.

Edukacja ku mądrości
Ten typ działań związany jest z kształtowaniem u uczniów zdolnych orientacji prospołecznej, ukierunkowanej na troszczenie się o wspólne dobro. Dzięki rozwijaniu trzech typów myślenia - refleksyjnego, dialektycznego i dialogicznego - poszerzają oni perspektywę postrzegania świata i ujmowania problemów w taki sposób, że dostrzegają ich wieloaspektowość oraz zróżnicowanie znaczeń (w percepcji zaangażowanych w nie podmiotów). W tym sensie edukacja ku mądrości kształtuje empatię uczniów zdolnych i chroni ich przed megalomanią, egocentryzmem czy nadmiernym krytycyzmem (Knopik 2018). 
Rozwój emocjonalno-społeczny
Wysokie ryzyko asynchronii rozwojowej uczniów zdolnych wymaga spójnych działań w obszarze kształtowania ich kompetencji emocjonalno-społecznych. Włączenie tych czynności w realizację podstawy programowej (zamiast tworzenia specjalnych zajęć temu poświęconych) daje szansę na wyposażenie uczniów $w$ trwałe zasoby transferowalne, umożliwiające im obecną i przyszłą adaptację.

Sposoby rozwijania kompetencji emocjonalno-społecznych $w$ ramach realizacji podstawy programowej zostały zawarte $w$ cyklu poradników w pakiecie TROS-KA (Domagała-Zyśk i in. 2017).

\section{Obszar: OSIAGNIECCIA}

TYP DZIALANIA

Udział w konkursach, Tego rodzaju działania sprawdzają efektywność udzielanego wsparcia, szczególolimpiadach

OPIS DZIAŁANIA nie w aspekcie poznawczym. Nie należy jednak traktować ich jako bezpośredniej i najważniejszej pomocy kierowanej do uczniów zdolnych. Warto pamiętać, że angażowanie tej samej osoby do kilku olimpiad może prowadzić do przeciążenia poznawczego i emocjonalnego, a także zredukowania roli ucznia do zawodnika biorącego udział w kolejnych konkursach.

Indywidualne plany rozwoju

Wspólne opracowanie z uczniem zdolnym jego indywidualnej ścieżki rozwoju, z wyraźnie opisanymi celami do osiągnięcia na poszczególnych etapach jest najlepszą strategią wzmacniania jego poczucia kompetencji i włączania ewentualnych gratyfikacji zewnętrznych w jego system wartości. W planach dostosowanych do osobistego potencjału uczeń może zaobserwować pokonywanie kolejnych granic (transgresje), co przekłada się na wzrost jego motywacji wewnętrznej - jednego z trzech kluczowych komponentów zdolności.

Organizacja konkursów dostosowanych do specyficznych uzdolnień uczniów
Uczniowie o bardzo specjalistycznych uzdolnieniach i zainteresowaniach, niekoniecznie pokrywających się z zakresem przedmiotów szkolnych, nie mają okazji do zaprezentowania swoich możliwości na zewnątrz (choć wykazują taką potrzebę). Stąd cenne są wszelkie inicjatywy organizacji wydarzeń wychodzących poza dotychczasowe praktyki, np. konkursy z zakresu historii polskiego futbolu lub projektowania architektury miejskiej, wystawa memów medycznych.

\section{Obszar: WSPARCIE}

TYP DZIAŁANIA

Współpraca szkół z podmiotami zewnętrznymi

\section{OPIS DZIAŁANIA}

Podejmowanie wspólnych inicjatyw z ekspertami z uczelni, lokalnych ośrodków kultury, organizacji pozarządowych w zakresie organizacji specjalistycznych zajęć rozwijających uzdolnienia. Uczelnie w ramach tzw. trzeciej misji są zobligowane do angażowania się w działania na rzecz środowiska lokalnego i wspomagania wszystkich potencjalnie zainteresowanych osób w procesie zdobywania zweryfikowanej metodami naukowymi wiedzy o współczesnym świecie.

Pedagog lub psycholog szkolny powinni na bieżąco monitorować inicjatywy mające na celu wspomaganie uczniów zdolnych. Okazuje się, że częstą barierą udziału w tych przedsięwzięciach jest brak dostępu do informacji. Tego typu oferty powinny być również dostępne dla rodziców, którzy w ramach czasu wolnego chcieliby wspomóc rozwój swoich dzieci.

\footnotetext{
Aktualizacja wiedzy nauczycieli na temat regionalnych i ogólnopolskich programów wspierania uczniów zdolnych
} 
Szkolenia z zakresu pracy z uczniami zdolnymi
Stworzenie atmosfery rzeczywiście sprzyjającej rozwojowi uczniów zdolnych wymaga poznania specyfiki ich funkcjonowania oraz strategii zaspokajania ich potrzeb. Udział w praktycznych warsztatach poświęconych temu zagadnieniu całej kadry pedagogicznej daje szansę na systemowe (a nie wybiórcze) podejście do tematu rozwijania talentów, dzięki czemu działania podejmowane przez poszczególnych nauczycieli będą spójne, co znacznie podniesie ich efektywność.

Mentoring
Objęcie przez nauczyciela-eksperta indywidualną opieką ucznia uzdolnionego w konkretnej dziedzinie. Przykładowo, biolog wchodzi w rolę mentora podopiecznego o silnych zainteresowaniach medycznych i w ramach realizacji wspólnie wypracowanej ścieżki rozwoju, wspiera go w osiąganiu kolejnych celów. Ważnym aspektem mentoringu jest również wspomaganie ogólnych procesów rozwojowych, a więc wyjście poza granice danego przedmiotu i skupianie się także na kształtowaniu osobowości ucznia.

\section{Podsumowanie}

Edukacja włączająca ma na celu stworzenie optymalnych warunków uczenia się dla wszystkich uczniów. I choć największa uwaga skupiona jest na zaprojektowaniu odpowiedniego wsparcia osób z niepełnosprawnościami i innymi trudnościami (barierami) rozwojowymi, nie można pomijać uczniów zdolnych. Stanowią oni 16-20\% populacji wszystkich uczniów, co oznacza, że należy w nowym modelu edukacji włączającej zadbać o ich potrzeby. Walcząc z różnymi odmianami dyskryminacji w polskiej szkole, nie zapominajmy o wyzwaniu, jakim jest dyskryminacja ze względu na zdolności. Do zbioru takich określeń typu ageizm, seksizm czy adultyzm można dodać zjawisko zwane „giftyzmem". Kontynuując tę myśl, warto zatem skonkludować, że jednym z obszarów inkluzji powinniśmy uczynić "antygiftyzm”, nie stać nas bowiem na marnowanie talentów. Co więcej - marnowanie talentów jest moralnie naganne! 


\section{Bibliografia}

$\rightarrow$ Achola, E.O. (2018), Practicing what we preach: Reclaiming the promise of multicultural transition programming [w:] Career development and transition for exceptional individuals, $\mathrm{nr}$ 0, s. 1-6.

$\rightarrow$ Adaszyńska, E. (2017), Projektowanie uniwersalne - dostępność i uczestnictwo dla wszystkich, „Uniwersytet Zielonogórski. Miesięcznik Społeczności Akademickiej", nr 2(240), s. 16-18.

$\rightarrow$ Aiken, L.R. (2002), Attitudes and related psychosocial constructs. Theories, assessment and research, Thousand Oaks-London-New Delhi: Sage Publication, Inc.

$\rightarrow$ Ainscow, M., Booth, T., Dyson, A. (2006), Improving schools, developing inclusion, London-New York: Routledge.

$\rightarrow$ Allan, J., Persson, E. (2015), Students' perspectives on raising achievement through inclusion in Essunga, Sweden, „Educational Review”, nr 68(1), s. 82-95.

$\rightarrow$ Al-Khamisy, D. (2004), Gotowość nauczycieli edukacji przedszkolnej do pracy z dziećmi o specjalnych potrzebach edukacyjnych [w:] G. Dryżałowska, H. Żuraw (red.), Integracja społeczna osób niepełnosprawnych, Warszawa: Wydawnictwo Akademickie "Żak".

$\rightarrow$ Anannikova, L. (2015), Polskie szkoły bojq się niepełnosprawnych dzieci. To dla nich niechciany problem, „Gazeta Wyborcza”, 19.06.2015, bit.ly/2Xnz4A7 [dostęp: 22.06.2019].

$\rightarrow$ Antecka, L., Bałtowska-Jucha, M., Głaz-Skirzyńska, M., Klaro-Celej, L., Wyszomierska, G., Zakrzewska, M. (2018), Model wdrożenia praktyk wspomaganych w szkołach przysposabiających do pracy. Podręcznik instruktażowy dla nauczycieli, Warszawa: CRZ.

$\rightarrow$ Antonovsky, A. (1995), Rozwikłanie tajemnicy zdrowia, jak radzić sobie ze stresem i nie zachorować, Warszawa: Fundacja IPN.

$\rightarrow$ Antonovsky, A. (1997), Poczucie koherencji jako determinant zdrowia [w:] I. Heszen-Niejodek, H. Sęk (red.), Psychologia zdrowia, Warszawa: PWN, s. 206-231. 
$\rightarrow$ Avramidis, E., Bayliss, P., Burden, R. (2000), A Survey into mainstream teachers' attitudes towards the inclusion of children with special educational needs in the ordinary school in on local education authority, "Educational Psychology", nr 20(2), s. 191-211.

$\rightarrow$ Avramidis, E., Kalyva, E. (2007), The influence of teaching experience and professional development on Greek teachers' attitudes towards inclusion, „European Journal of Special Needs Education", nr 22(4), s. 367-389.

$\rightarrow$ Avramidis, E., Norwich, B. (2002), Teachers' attitudes towards integration/inclusion: A review of the literature , "European Journal of Special Needs Education”, nr 17(2), s. 129-147.

$\rightarrow$ Badegruber, B. (1997), Nauczanie otwarte w 28 krokach, Warszawa: WSiP.

$\rightarrow$ Bajewska-Kołodziejak, A., Cichocka-Segiet, K., Czajkowska-Kisil, M., Mostowski, P., Rutkowski, P., Skuza, M., Ziątek, K. (2014), Poradnik dla nauczyciela. Nasz elementarz. Podręcznik do szkoły podstawowej. Klasa 1. Część 1. Adaptacja dla uczniów ze specjalnymi potrzebami edukacyjnymi, Warszawa: Ministerstwo Edukacji Narodowej.

$\rightarrow$ Bajewska-Kołodziejak, A., Cichocka-Segiet, K., Danowska-Florczyk, E., Mostowski, P., Rutkowski, P., Skuza, M., Ziątek, K. (2017), Ksiq̨żka pomocnicza zawierajq̨ca materiał informacyjny dotyczq̨cy zalecanych sposobów korzystania z adaptacji. Szkolni przyjaciele. Matematyka. Podręcznik. Klasa 1. Część 1, Warszawa: Ministerstwo Edukacji Narodowej.

$\rightarrow$ Baker, D.J., Vaks, B. (2015), Employment for people with intellectual or developmental disabilities and challenging behavior [w:] Way leads on to way. Paths to employment for people with intellectual disabilities, Washington DC: AAIDD.

$\rightarrow$ Baker, E.T., Wang, M.C., Walberg, H.J. (1994/1995), The effects of inclusion on learning, „Educational Leadership”, nr 52.

$\rightarrow$ Bańka, A. (2000), Psychologia organizacji [w:] J. Strelau (red.), Psychologia. Podręcznik akademicki, t. 3, Gdańsk: GWP, s. 321-350.

$\rightarrow$ Bańka, A. (2005), Rozwój zawodowy a ścieżki tranzycji z systemu edukacji do rynku pracy [w:] Doradztwo Karier, Warszawa: OHP.

$\rightarrow$ Barłóg, K. (2008), Wspomaganie rozwoju dzieci z niepełnosprawnościq intelektualng w stopniu lekkim w różnych formach edukacji wczesnoszkolnej, Rzeszów: Wydawnictwo Uniwersytetu Rzeszowskiego.

$\rightarrow$ Barnes, P. (2008), Multi-agency working: what are the perspectives of SENCos and parents regarding its development and implementation?, „British Journal of Special Education" nr 35(4), s. 230-240.

$\rightarrow$ Bartkowiak, G. (2009), Człowiek w pracy. Od stresu do sukcesu w organizacji, Warszawa: Polskie Wydawnictwo Ekonomiczne. 
$\rightarrow$ Bartkowski, J. (2007), Między stygmatyzacjq a odrzuceniem. System szkolny a przygotowanie zawodowe młodych osób niepełnosprawnych [w:] E. Giermanowska (red.), Młodzi niepełnosprawni - aktywizacja zawodowa i nietypowe formy zatrudnienia, Warszawa: ISP.

$\rightarrow$ Bartnikowska, U., Wójcik, M. (2004), Zaniedbania w aspekcie triady: szkoła rodzice - dziecko w kształceniu integracyjnym i masowym dzieci z wadq słuchu [w:] Z. Gajdzica, D. Osik-Chudowolska (red.), Wq̨tki zaniedbane, zaniechane, nieobecne w procesie edukacji i wsparcia społecznego osób niepełnosprawnych, Warszawa, Wydawnictwo UŚ, s. 287-299.

$\rightarrow$ Barzykowski, K., Grzymała-Moszczyńska, H., Dzida, D., Grzymała Moszczyńska, J., Kosno, M. (2013), One sq wśród nas. Wybrane zagadnienia diagnozy psychologicznej dzieci i młodzieży w kontekście wielokulturowości oraz wielojęzyczności, Warszawa: Ośrodek Rozwoju Edukacji, bit.ly/2X19Sjm [dostęp: 22.06.2019].

$\rightarrow$ Bąbka, J. (2003), Psychologiczne aspekty efektywności edukacji dzieci w systemie integracyjnym [w:] Z. Kazanowski, D. Osik-Chudowolska (red.), Integracja osób niepełnosprawnych w edukacji i integracjach społecznych, Lublin: Wydawnictwo UMCS.

$\rightarrow$ Bejerot, S., Edgar, J., Humble, M.B. (2011), Poor performance in physical education: A risk factor for bully victimization. A case-control study, "Acta Paediatrica”, nr 100(3), s. 413-419.

$\rightarrow$ Bennett, S., Gallagher, T.L. (2013), High school students with intellectual disabilities in the school and workplace: Multiple perspectives on inclusion, „Canadian Journal of Education", nr 36(4), s. 96-124.

$\rightarrow$ Bernacka-Langier, A., Janik-Płocińska, B., Kosowicz, A., Pawlic-Rafałowska, E. (2009), Inny w Polskiej szkole. Poradnik dla nauczycieli pracującymi z cudzoziemcami, Warszawa: Biuro Edukacji Urzędu m.st. Warszawy, Polskie Forum Migracyjne, Warszawskie Centrum Innowacji Edukacyjno-Społecznych i Szkoleń.

$\rightarrow$ Berry, J.W. (1998), Acculturation and health [w:] W.S.S. Kazarian, D.R. Evans (red.), Cultura clinical psychology. Theory research and practice, New York: Oxford University Press.

$\rightarrow$ Bidziński, K. (2007), Znaczenie nadawane zjawisku niepełnosprawności przez młodzież sprawnq, w kontekście kształtowania się tożsamości osób z dysfunkcjq̨ narzq̨du ruchu [w:] B. Jachimczak, B. Olszewska, D. Podgórska-Jachnik (red.), Miejsce Innego we współczesnych naukach o wychowaniu, Łódź: Satori, s. 76-79.

$\rightarrow$ Black-Hawkins, K., Florian, L., Rouse, M. (2007), Achievement and inclusion in school, London: Routledge. 
$\rightarrow$ Blecker, N.S, Boakes, N.J. (2010), Creating a learning environment for all children: are the teachers able and willing?, „International Journal of Inclusive Education", nr 14(5), s. 435-447.

$\rightarrow$ Błeszyńska, K. (1992), Determinanty przystosowania ucznia niepełnosprawnego do środowiska szkoły masowej [w:] A. Hulek, B. Grochmal-Bach (red.), Uczeń niepełnosprawny w szkole masowej, Kraków: Wydawnictwo WSP.

$\rightarrow$ Booth, T., Ainscow, M. (2002), Index for inclusion, developing learning and participation in schools, bit.ly/2MJTaeo [dostęp: 10.02.2019].

$\rightarrow$ Borkowska, A. (2016), Psychologiczne aspekty migracji w rozwoju dziecka [w:] E. Śmiechowska-Petrovskij (red.), Dzieci z trudnościami adaptacyjnymi w młodszym wieku. Aspekty rozwojowe i edukacyjne w kontekście specyfiki różnic kulturowych, Warszawa: Wydawnictwo Naukowe UKSW.

$\rightarrow$ Boski, P. (2009), Kulturowe ramy zachowań społecznych. Podręcznik psychologii międzykulturowej, Warszawa: Wydawnictwo Naukowe PWN.

$\rightarrow$ Brophy, J. (2007), Motywowanie uczniów do nauki, Warszawa: Wydawnictwo Naukowe PWN.

$\rightarrow$ Brown, W.H., Odom, S.L, Conroy, M.A. (2001), An intervention hierarchy for promoting young children's peer interactions in natural environments, "Topics in Early Childhood Special Education", nr 21(3), s. 162-175.

$\rightarrow$ Bruner, J. (2006), Kultura edukacji, Kraków: Universitas.

$\rightarrow$ Brzezińska, A. (2000), Społeczna psychologia rozwoju, Warszawa: Scholar.

$\rightarrow$ Brzezińska, A. (2002), Współczesne ujęcie gotowości szkolnej [w:] W. Brejnak (red.), O pomyślny start ucznia w szkole, „Biuletyn Informacyjny Polskiego Towarzystwa Dysleksji - Wydanie specjalne".

$\rightarrow$ Buchnat, M. (2015), Formy organizacji kształcenia dziecka z lekkq niepełnosprawnościq intelektualnq a jego kompetencje społeczne, Poznań: Wydawnictwo Naukowe UAM.

$\rightarrow$ Capp, M.J. (2017), The effectiveness of universal design for learning: a meta-analysis of literature between 2013 and 2016, „International Journal of Inclusive Education", nr 8(21), s. 791-807.

$\rightarrow$ Caprara, G.V., Barbaranelli, C., Patorelii, C., Bandura, A., Zimbardo, P.G. (2000), Prosocial Foundations of Children's Academic Achievement, „Psychological Science", nr 11(4), s. 302-306.

$\rightarrow$ Carlberg, C., Kavale, K., (1980), The efficacy of special versus regular class placement for exceptional children: A meta-analysis, „Journal of Special Education”, nr 14(3), s. 295-309. 
$\rightarrow$ Carlisle, E., Stanley, L., Kemple, K.M. (2005), Opening doors: Understanding school and family influences on family involvement, „Early Childhood Education Journal", nr 33(3), s. 155-162.

$\rightarrow$ CAST (2018a), Universal design for learning guidelines version 2.2 [graphic organizer], Wakefield, MA: Author.

$\rightarrow$ CAST (2018b), UDL and the learning brain, Wakefield, MA: Author, bit.ly/2WTYdOY [dostęp: 18.02.2019].

$\rightarrow$ Chesmore, A.A., Ou, R.-S., Reynolds, A.J. (2016), Childhood placing in special education and adult well-being, "The Journal of Special Education", nr 50, s. 109-120.

$\rightarrow$ Chmielińska, A., Modrzejewska-Świgulska, M. (2018), Bariery w pracy nauczycieli oraz innowatorów edukacyjnych w perspektywie badań pedagogicznych, "EETP", t. 13, nr 2(48).

$\rightarrow$ Chodkowska, M. (2001), Socjopedagogiczne aspekty edukacji integracyjnej - nadzieje i realia w warunkach reformy systemu oświaty [w:] Z. Palak (red.), Pedagogika specjalna w reformowanym ustroju edukacyjnym, Lublin: Wydawnictwo UMCS.

$\rightarrow$ Chodkowska, M. (2004), Problemy pedagogicznego wsparcia uczniów z niepełnosprawnościq̨ intelektualnq w zakresie społecznego funkcjonowania w klasie szkolnej [w:] Z. Palak, Z. Bartkowicz (red.), Wsparcie społeczne w rehabilitacji i resocjalizacji, Lublin: Wydawnictwo UMCS, s. 63-73.

$\rightarrow$ Christenson, S.L., Sheridan, S.M. (2001), School and families: Creating essential connections for learning, New York: Guilford Press.

$\rightarrow$ Chrzanowska, I. (2003), Funkcjonowanie dzieci upośledzonych umysłowo w stopniu lekkim w szkole podstawowej, Łódź: Wydawnictwo UŁ.

$\rightarrow$ Chrzanowska, I. (2010), Problemy edukacji dzieci i młodzieży z niepełnosprawnościq̨. Regionalna specyfika czy ogólnopolska tendencja, Kraków: Oficyna Wydawnicza Impuls.

$\rightarrow$ Chrzanowska, I. (2015), Pedagogika specjalna. Od tradycji do współczesności, Kraków, Oficyna Wydawnicza Impuls.

$\rightarrow$ Chrzanowska, I. (2018), Edukacja włączajq̨ca-wyzwanie dla kompetencji pedagogów specjalnych, "Studia Edukacyjne”, nr 48, s. 23-32.

$\rightarrow$ Chrzanowska, I. (2019), Nauczyciele o szansach i barierach edukacji włączajqcej, Warszawa: Wydawnictwo Naukowe PWN.

$\rightarrow$ Chrzanowska, l., Jachimczak, B. (2015), Praca wychowawcza w grupie zróżnicowanej- uczeń ze specjalnymi potrzebami edukacyjnymi w szkole ogólnodostępnej [w:] J. Pyżalski (red.), Wychowawcze i społeczno-kulturowe kompetencje współczesnych nauczycieli, Łódź: theQ studio. 
$\rightarrow$ Connell, B.R., Jones, M., Mace, R., Mueller, J., Mullick, A., Ostroff, E., Sanford, J., Steinfeld, E., Story, M., Vanderheiden, G. (1997), The principles of Universal Design, bit.ly/2kfE2tl [dostęp: 18.02.2019].

$\rightarrow$ Corno, L. (2008), On teaching adaptively, „Educational Psychologist”, nr 43, s. $161-173$.

$\rightarrow$ Currie, C., Zanotti, C., Morgan, A., Currie, D., de Looze, M., Roberts, C., Samdal, O., Smith, O.R.F., Barnekow, V. (2012), Social determinants of health and well-being among young people: Health behaviour in school-aged children (HBSC) study: international report from the 2009/2010 survey, Copenhagen: WHO Regional Office for Europe (Health Policy for Children and Adolescents, nr 6), bit.ly/L6c8M3 [dostęp: 14.02.2019].

$\rightarrow$ Czapiński, J. (2009), Diagnoza szkolna 2009. Raport roczny programu społecznego "Szkoła bez przemocy”, www.szkolabezprzemocy.pl [dostęp: 14.01.2019].

$\rightarrow$ Czapiński, J., Panek, T. (red.) (2015), Diagnoza społeczna 2015. Warunki i jakość życia Polaków, bit.ly/2Xr23mx [dostęp: 22.06.2019].

$\rightarrow$ Czykwin, E. (2007), Stygmat społeczny, Warszawa: Wydawnictwo Naukowe PWN.

$\rightarrow$ Ćwirynkało, K. (2003), Pozycja socjometryczna uczniów niepełnosprawnych a postawa nauczycieli wobec integracji [w:] Z. Kazanowski, D. Osik-Chudowolska (red.), Integracja osób niepełnosprawnych w edukacji i interakcjach społecznych, Lublin: Wydawnictwo UMCS.

$\rightarrow$ de Boer, A., Pijl. S.J., Minnaert, A. (2011), Regular primary schoolteachers' attitudes towards inclusive education: a review of the literature, „International Journal of Inclusive Education", nr 3, s. 331-353.

$\rightarrow$ Dembo, M.H. (1997), Stosowana psychologia wychowawcza, Warszawa: Wydawnictwa Szkolne i Pedagogiczne.

$\rightarrow$ Deptuła, M. (2013), Odrzucenie rówieśnicze. Profilaktyka i terapia, Warszawa: Wydawnictwo Naukowe PWN.

$\rightarrow$ Dessemontet, R.S., Bless, G., Morin, D. (2012), Effects of inclusion on academic achievement and adaptive behaviour of children with intellectual disabilities ,IJournal of Intellectual Disability Research", nr 56(6), s. 579-587.

$\rightarrow$ Deunk, M.I., Smale-Jacobse, A.E., de Boer, H., Doolaard, S., Bosker, R.J. (2018), Effective differentiation Practices: A systematic review and meta-analysis of studies on the cognitive effects of differentiation practices in primary education, „Educational Research Review”, nr 24, s. 31-54.

$\rightarrow$ Dłużniewska, A., Szubielska, M. (2017), Diagnoza-definicja, klasyfikacje, model, narzędzia [w:] K. Krakowiak (red.), Diagnoza specjalnych potrzeb rozwojowych i edukacyjnych dzieci i młodzieży. Standardy, wytyczne oraz wskazówki do 
przygotowywania i adaptacji narzędzi diagnostycznych dla dzieci i młodzieży z wybranymi specjalnymi potrzebami rozwojowymi i edukacyjnymi, Warszawa: Ośrodek Rozwoju Edukacji, s. 20-41, bit.ly/2XtUoUr [dostęp: 22.06.2019].

$\rightarrow$ Domagała-Zyśk, E. (2015), Projektowanie uniwersalne w edukacji osób z wadq słuchu [w:] M. Nowak, E. Stoch, B. Borowska (red.), Z problematyki teatrologii i pedagogiki, Lublin: Wydawnictwo KUL, s. 553-568.

$\rightarrow$ Domagała-Zyśk, E. (2018), Personel pomocniczy w szkołach ogólnodostępnych w Europie i USA - wyniki badań nad modelem i skutecznościq wsparcia, Warszawa: Ministerstwo Edukacji Narodowej.

$\rightarrow$ Domagała-Zyśk, E., Knopik, T., Oszwa, U., Knopik, M., Konowałek, A., Krajewska, M., Mazur, J., Sudewicz, K., Zakrzewska, E. (2017), Jak rozwijać wśród uczniów pozytywny obraz siebie? Poradnik dla pracowników poradni psychologiczno-pedagogicznych. TROS-KA Materiały postdiagnostyczne, Warszawa: Ośrodek Rozwoju Edukacji.

$\rightarrow$ Dudzikowska, M. (2001), Mit o szkole jako miejscu wszechstronnego rozwoju ucznia, Kraków: Oficyna Wydawnicza Impuls, s. 137-138.

$\rightarrow$ Dyduch, E. (1999), Izolacja społeczna uczniów z obniżonq sprawnościq intelektualnq w szkole publicznej [w:] J. Pańczyk, W. Dykcik (red.), Pedagogika specjalna wobec zagrożeń i wyzwań XXI wieku, Poznań: Wydawnictwo UAM, s. 243-249.

$\rightarrow$ Dykcik, W. (2003), Człowiek dorosły niepełnosprawny w poszukiwaniu sensu życia [w:] K.D. Rzedzicka, A. Kobylańska (red.), Dorosłość, niepełnosprawność, czas wolny. Na pograniczach pedagogiki specjalnej, Kraków: Oficyna Wydawnicza Impuls.

$\rightarrow$ Dyon, A. (2000), Inclusion and inclusions: theories and discourses in inclusive education [w:] H. Daniels, P. Garner (red.), Inclusive education. World yearbook of education, London: Kogan Page.

$\rightarrow$ Dzierzgowska, I. (2007), Szkoła dla zdolnych. Opinia na temat projektu zmiany ustawy o systemie oświaty (druk sejmowy nr 1354), www.monitor.edu.pl [dostęp: 15.02.2019].

$\rightarrow$ Eagly, A.H., Chaiken, S. (1993), The psychology of attitudes, Philadelphia: Harcourt Brace Jovanovich College Publisher.

$\rightarrow$ Edyburn, D.L. (2010), Would you recognize unversal design for learning if you saw it? The propositions for new directions for the second decade of UDL, "Learning Disability Quarterly", nr 33(1), s. 33-41.

$\rightarrow$ Ekiert-Grabowska, D. (1982), Dzieci nieakceptowane w klasie szkolnej, Warszawa: Wydawnictwa Szkolne i Pedagogiczne. 
$\rightarrow$ Ekiert-Grabowska, D. (1984), Techniki socjometryczne w pracy wychowawcy klas początkowych, Katowice: Wydawnictwo UŚ.

$\rightarrow$ Ekiert-Grabowska, D. (1994), Syndrom nieadekwatnych osiqggnięć szkolnych, "Życie Szkoły", nr 3, s. 131-136.

$\rightarrow$ Epstein, J.L. (2001), School, family, and community partnerships: Preparing educators and improving schools, Boulder CO: Westview.

$\rightarrow$ Erikson, E.H. (1968), Identity, youth and crisis, New York: Norton.

$\rightarrow$ Erikson, E.H. (1997), Dzieciństwo i społeczeństwo, Poznań: Rebis.

$\rightarrow$ Erten, O., Savage, R.S. (2012), Moving forward in inclusive education research, „International Journal of Inclusive Education", nr 16, s. 221-233.

$\rightarrow$ Europejska Agencja ds. Specjalnych Potrzeb i Edukacji Włączającej (2013), Organisation of provision to support inclusive education - Meeting the needs of all learners - a school transformation. Nossebro School, Essunga, Sweden, 26-28 February 2013, Odense, Dania.

$\rightarrow$ Europejska Agencja ds. Specjalnych Potrzeb i Edukacji Włączającej (2014), Organizacja wsparcia dla edukacji włączającej-raport podsumowujący, Odense, Dania.

$\rightarrow$ Europejska Agencja ds. Specjalnych Potrzeb i Edukacji Włączającej (2015), Stanowisko Agencji dotyczq̨ce edukacji włączającej, Odense, Dania, bit.ly/2XoGZx5 [dostęp: 1.03.2019].

$\rightarrow$ Europejska Agencja ds. Specjalnych Potrzeb i Edukacji Włączającej (2016), Raising the achievement of all learners in inclusive education - Literature review, A. Kefallinou (red.), Odense, Dania, bit.ly/2XyLtRH [dostęp: 24.06.2019].

$\rightarrow$ Europejska Agencja ds. Specjalnych Potrzeb i Edukacji Włączającej (2017a), Podnoszenie osiągnięć wszystkich uczniów w edukacji włączajq̨cej. Końcowy raport podsumowujący, V.J. Donnelly, A. Kefallinou (red.), Odense, Dania, bit.ly/2X5dPna [dostęp: 24.06.2019].

$\rightarrow$ Europejska Agencja ds. Specjalnych Potrzeb i Edukacji Włączającej (2017b), Raising the Achievement of All Learners: A Resource to Support Self-Review, Odense, Dania, bit.ly/2EV1cjz [dostęp: 6.06.2019].

$\rightarrow$ Europejska Agencja ds. Specjalnych Potrzeb i Edukacji Włączającej (2018), Dowody na zwiq̨zek edukacji włączajq̨cej z włączeniem społecznym: końcowy raport podsumowujący, S. Symeonidou (red.), Odense, Dania.

$\rightarrow$ Europejska Agencja ds. Specjalnych Potrzeb i Edukacji Włączającej (2018a), Raising the achievement of all learners in inclusive education: Lessons from European policy and practice, V.J. Donnelly, A. Kefallinou (red.), Odense, Dania, bit.ly/2FrVPZo [dostęp: 1.03.2019]. 
$\rightarrow$ Europejska Agencja ds. Specjalnych Potrzeb i Edukacji Włączającej (2018b), Key actions for raising achievement: Guidance for teachers and leaders, V. Donnelly, A. Kefallinou, (red.), Odense, Dania, bit.ly/2X63iZa [dostęp: 1.03.2019].

$\rightarrow$ Europejska Agencja ds. Specjalnych Potrzeb i Edukacji Włączającej (2018c), Evidence of the link between inclusive education and social inclusion: a review of the literature, S. Symeonidou (red.), Odense, Dania, bit.ly/2Ft6C5H [dostęp: 1.03.2019].

$\rightarrow$ Europejska Agencja ds. Specjalnych Potrzeb i Edukacji Włączającej (2018d), Supporting inclusive school leadership: Literature review, E. Óskarsdóttir, V.J. Donnelly, M. Turner-Cmuchal (red.), Odense, Dania, bit.ly/2WYW9Ve [dostęp: 1.03.2019].

$\rightarrow$ Europejska Agencja ds. Specjalnych Potrzeb i Edukacji Włączającej (2019), Wspieranie podnoszenia jakości edukacji włączajq̨cej w Polsce-rekomendacje końcowe, Odense, Dania.

$\rightarrow$ Europejska Agencja ds. Specjalnych Potrzeb i Edukacji Włączającej (w druku), Podnoszenie osiągnięć wszystkich uczących się w edukacji integracyjnej: Follow-up study, D. Watt (red.), Odense, Dania.

$\rightarrow$ Europejska Agencja Rozwoju Edukacji Uczniów ze Specjalnymi Potrzebami (2011), Kształcenie nauczycieli przygotowujące do edukacji włączającej-wyzwania i szanse, Odense, Dania, bit.ly/2N8rVQ9 [dostęp: 23.06.2019].

$\rightarrow$ Europejska Agencja Rozwoju Edukacji Uczniów ze Specjalnymi Potrzebami (2012), Profil nauczyciela edukacji włączającej. Odense, Dania, bit.ly/2X1FsZj [dostęp: 22.06.2019].

$\rightarrow$ Farrell, P., Dyson, A., Polat, F., Hutcheson, G., Gallannaugh, F. (2007), Inclusion and achievement in mainstream schools, "European Journal of Special Needs Education", nr 22, s. 131-145.

$\rightarrow$ Fazlagić, J. (2014), Porównanie systemów edukacyjnych w Polsce i Finlandii, bit.ly/2YfLpUh [dostęp: 10.02.2019].

$\rightarrow$ Federowicz, M., i in. (2013), Czas pracy i warunki pracy w relacjach nauczycieli. Raport tematyczny z badania, Warszawa, Instytut Badań Edukacyjnych.

$\rightarrow$ Federowicz, M., Sitek, M. (2012), Badania - polityka społeczna - polityka edukacyjna - potrzeby praktyki, „Polityka Społeczna”, nr 1 (tematyczny), bit.ly/2XrRNdB [dostęp: 22.02.2019].

$\rightarrow$ Fedorczuk, M. (2018), Technologie na rynku pracy czy już praca na rynku technologii, bit.ly/2qLIBjG [dostęp: 20.02.2019].

$\rightarrow$ Fedorowicz, M. (2007), Projektowanie Uniwersalne. Implementacja w obszarze edukacji i bibliotekarstwa szkolnego [w:] „Przegląd Biblioteczny”, z. 3, s. 399-407. 
$\rightarrow$ Ferreira, M. (2015), Portugalski systemu edukacji dla uczniów z niepełnosprawnościami - materiały z międzynarodowej konferencji "Kształcenie uczniów z niepełnosprawnościami", Łódź.

$\rightarrow$ Fielding, M., Bragg, S., Craig, J., Cunningham, I., Eraut, M., Gillinson, S., Horne, M., Robinson, C., Thorp, J. (2005), Factors Influencing the Transfer of Good Practice, London: Department for Education and Skills.

$\rightarrow$ Fińskie Biuro Eurydice (oprac.) (2012), Systemy edukacji w Europie - stan obecny i planowane reformy, bit.ly/2Y6yfbZ [dostęp: 10.02.2019].

$\rightarrow$ Forlin, C. (2001), Inclusion: Identifying potential stressors for regular class teachers, "Educational Research", nr 43(3), s. 235-245.

$\rightarrow$ Forlin, C. (2006), Inclusive education in Australia ten years after Salamanca, „European Journal of Psychology of Education”, nr 21(3), s. 265-277.

$\rightarrow$ Forlin, C. (2010), The role of the school psychologist in inclusive education for ensuring quality lerning outcomees for all learners, „School Psychology International", nr 31(1), s. 617-630.

$\rightarrow$ Forlin, C, Chambers, D. (2003), Bullying and the inclusive school environment, "The Australian Journal of Teacher Education", nr 28(2), s. 11-23.

$\rightarrow$ Freire, P. (1993), The pedagogy of the oppressed, London: Penguin Books.

$\rightarrow$ Fuchs, D., Fuchs, L.S. (1998), Evaluation of the Adaptive Learning Environments Model. „Exceptional Children”, nr 55(2), s. 115-127.

$\rightarrow$ Gajdzica, Z. (2001), Nauczyciel edukacji wczesnoszkolnej w zreformowanej szkole powszechnej jako organizator procesu kształcenia dziecka upośledzonego umysłowo w stopniu lekkim [w:] Z. Palak (red.), Pedagogika specjalna w reformowanym ustroju edukacyjnym, Lublin: Wydawnictwo UMCS.

$\rightarrow$ Gajdzica, Z. (2011), Sytuacje trudne w opinii nauczycieli klas integracyjnych, Kraków, Oficyna Wydawnicza Impuls.

$\rightarrow$ Gajdzica, Z. (2011), Opinie nauczycieli szkół ogólnodostępnych na temat edukacji włączajq̨cej uczniów z lekkim upośledzeniem umysłowym w kontekście toczącej się reformy kształcenia specjalnego [w:] Z. Gajdzica (red.), Uczeń z niepełnosprawnościq w szkole ogólnodostępnej, Sosnowiec: Oficyna Wydawnicza „Humanitas", s. 56-81.

$\rightarrow$ Gajdzica, Z. (2013), Kategorie sukcesów w opiniach nauczycieli klas integracyjnych jako przyczynek do poszukiwania koncepcji edukacji integracyjnej, Kraków: Oficyna Wydawnicza Impuls.

$\rightarrow$ Gallagher, P.A., Floyd J.H., Stafford A.M., Taber T.A., Brozovic S.A., Alberto, P.A. (2000), Inclusion of students with moderate or severe disabilities in education and community settings: Perspectives from parents and siblings, „Education 
and Training in Mental Retardation and Developmental Disabilities", 35(2), s. $135-147$.

$\rightarrow$ Garlej-Drzewiecka, E. (2004), Pedeutologiczny kontekst myślenia o nauczycielu wiodq̨cym i wspierajq̨cym [w:] C. Kosakowski, A. Krause (red.), Dyskursy pedagogiki specjalnej. Rehabilitacja, opieka i edukacja specjalna w perspektywie zmian, Olsztyn: Wydawnictwo UWM.

$\rightarrow$ Głodkowska, J. (1999), Poznanie ucznia szkoły specjalnej, Warszawa: Wydawnictwa Szkolne i Pedagogiczne.

$\rightarrow$ Göransson, K., Nilholm, C. (2014), Conceptual diversities and empirical shortcomings - a critical analysis of research on inclusive education, "European Journal of Special Needs Education", nr 29(3), s. 265-280.

$\rightarrow$ Gronneberg, J., Johnston, S. (2015), 7 things you should know about Universal Design for Learning, bit.ly/31NUztj [dostęp: 18.02.2019].

$\rightarrow$ Gross, J.M.S, Haines, S.J., Hill, C., Francis, G.L., Blue-Banning, M., Turnbull, A.P. (2015), Strong school-community partnerships in inclusive schools are "Part of the fabric of the school... we count on them", „School Community Journal", nr 25(2), s. 9-34.

$\rightarrow$ Grzegorzewska, M. (2002), Listy do Młodego Nauczyciela, Warszawa: Akademia Pedagogiki Specjalnej im. Marii Grzegorzewskiej, s. 59.

$\rightarrow$ Grzelak, P., Kubicki, P., Orłowska, M. (2014), Realizacja badania ścieżek edukacyjnych niepełnosprawnych dzieci, uczniów i absolwentów - Raport końcowy, Warszawa: Instytut Badań Edukacyjnych.

$\rightarrow$ Grzymała-Moszczyńska, H., Grzymała-Moszczyńska, M., Durlik, J., Szydłowska, P. (2015), (Nie)łatwe powroty do domu. Funkcjonowanie dzieci i młodzieży powracajg̨cych z emigracji, Warszawa: Fundacja Centrum im. prof. Bronisława Geremka, bit.ly/31RmF70 [dostęp: 22.06.2019].

$\rightarrow$ Guralnick, M.J. (1992), A hierarchical model for understanding children's peer-related social competence [w:] S.L. Odom, S.R. McConnell, M.A. McEvoy (red.), Social competence of young children with disabilities: Issues and strategies for intervention, Baltimore: Brookes Publishing, s. 37-64.

$\rightarrow$ GUS (2017), Oświata i wychowanie w roku szkolnym 2016/2017, Warszawa: Główny Urząd Statystyczny.

$\rightarrow$ Guziuk-Tkacz, M. (2011), Badania diagnostyczne w pedagogice i psychopedagogice, Warszawa: Wydawnictwo Akademickie „Żak".

$\rightarrow$ Hajnicz, W. (2010), Ocena i diagnoza w procesie edukacyjnym [w:] A. Konieczna (red.), Diagnozowanie potrzeb edukacyjnych dziecka, Warszawa: Wydawnictwo APS, s. 9-53.

$\rightarrow$ Hattie, J. (2009), Visible learning, London-New York: Routledge. 
$\rightarrow$ Hattie, J. (2015), Widoczne uczenie się dla nauczycieli. Jak maksymalizować siłę oddziaływania na uczenie się, Warszawa: Centrum Edukacji Obywatelskiej.

$\rightarrow$ Healy, S. (2014), Preventing bullying in inclusive physical education. Strategies for teachers, „Palaestra”, nr 28(2), s. 42-46.

$\rightarrow$ Hebl, M.R., Kleck, R.E. (2008), Społeczne konsekwencje niepełnosprawności fizycznej [w:] T.F. Heatherton, R.E. Kleck, M.R. Hebl, J.G. Hull (red.), Społeczna psychologia piętna, Warszawa: Wydawnictwo Naukowe PWN.

$\rightarrow$ Hendersen, A.T., Mapp, K.L. (2002), A new wave of evidence: The impact of school, family and community connections on students' achievement, Austin: Southwest Educational Laboratory.

$\rightarrow$ Hernik, K. (2015), Przywództwo w szkole: role i zadania dyrektorów [w:] K. Hernik (red.), Polscy nauczyciele i dyrektorzy w Międzynarodowym Badaniu Nauczania i Uczenia się TALIS 2013, Warszawa: Instytut Badań Edukacyjnych.

$\rightarrow$ Hernik, K., Malinowska, K. (2015), Jak skutecznie współpracować i komunikować się z rodzicami i społecznością lokalnq̨, Warszawa: Instytut Badań Edukacyjnych.

$\rightarrow$ Hilbert, D. (2014), Perceptions of Parents of Young Children with and without Disabilities Attending Inclusive Preschool Programs, „Journal of Education and Learning", t. 3, nr 4.

$\rightarrow$ Hildebrandt, A. (2001), Koncepcja rozwoju organizacyjnego szkoły Pera Dalina [w:] E. Potulicka (red.), Szkice z teorii i praktyki zmiany oświatowej, Poznań: Wydawnictwo ERUDITUS, s. 62.

$\rightarrow$ Hofstede, G., Hofstede, G.J., Minkov, M. (2010), Cultures and organizations. Software of the mind. intercultural cooperation and its importance for survival, New York-Chicago-San Francisco: McGraw-Hill.

$\rightarrow$ Holmes, J., Gathercole, S.E., Dunnin, D.L. (2009), Adaptive training leads to sustained enhancement of poor working memory in children, „Developmental Science", nr 12(4), s. 9-15.

$\rightarrow$ Holopainen, L., Lappalainen, K., Junttila, N., Savolainen, H. (2012), The role of social competence in the psychological well-being of adolescents in secondary education, "Scandinavian Journal of Educational Research”, nr 56(2), s. 199-212.

$\rightarrow$ Hornby, G. (2014), Inclusive special education, New York-Heidelberg-Dordrecht-London: Springer.

$\rightarrow$ Howes, C., Phillipsen, L. (1998), Continuity in children's relations with peers, "Social Development", nr 7, s. 340-349.

$\rightarrow$ Hurlock, E.B. (1985), Rozwój dziecka, Warszawa: Wydawnictwo Naukowe PWN.

$\rightarrow$ Jachimczak, B. (2012), Funkcjonowanie triady: dziecko, rodzic, nauczyciel/wychowawca we współczesnej szkole. Współdziałanie a autorytet [w:] A. Valisova 
(red.), Autorita v edukacni a socialni praci, Pardubice: Univerzita Pardubice, s. $160-164$.

$\rightarrow$ Jachimczak B. (2018), Kształcenie nauczycieli dla edukacji włączajq̨cej, „Studia Edukacyjne" nr 48, s. 33-43.

$\rightarrow$ Jakoniuk-Diallo, A. (2010), O co pytajq rodzice dzieci z niepełnosprawnościq, Warszawa: Difin.

$\rightarrow$ Jamison, K.R., Forston, L.D., Stanton-Chapman, T.L. (2012), Encouraging social skill development through play in early childhood special education classrooms, „Young Exceptional Children", nr 15, s. 3-19.

$\rightarrow$ Janion, E. (1999), Stosunki emocjonalno-społeczne między dziećmi pełnosprawnymi i niepełnosprawnymi w przedszkolnej grupie rówieśniczej [w:] A. Maciarz (red.), Z teorii i badań społecznej integracji dzieci niepełnosprawnych, Kraków, Oficyna Wydawnicza Impuls.

$\rightarrow$ Janion, E. (2001), Stosunki koleżeńskie między dziećmi pełnosprawnymi i niepełnosprawnymi w przedszkolnych grupach integracyjnych [w:] M. Heine (red.), Problemy integracji społecznej osób niepełnosprawnych i niedostosowanych, Zielona Góra: Wydawnictwo UZ.

$\rightarrow$ Janke, A.W. (2012), Transformacja $w$ stosunkach rodziny i szkoły na przełomie XX i XXI wieku. Perspektywy zmiany społecznej w edukacji, Bydgoszcz: Wydawnictwo Akademii Bydgoskiej im. Kazimierza Wielkiego.

$\rightarrow$ Jankowska, A. (2012), Rozmowy z rodzicami. Poradnik dla nauczyciela, Kielce: Wydawnictwo Pedagogiczne ZNP.

$\rightarrow$ Jepma, I. (2003), De schoolloopbaan van risicoleerlingen in het primair onderwijs [The school career of pupils at risk in primary education], Amsterdam: Thela Thesis.

$\rightarrow$ John, M., Baylis, P. (1994), Włączający system edukacji [w:] J. Bogucka, M. Kościelska (wybór i oprac.), Wychowanie i nauczanie integracyjne: materiały dla nauczycieli i rodziców, Warszawa: Społeczne Towarzystwo Oświatowe, s. 17-21.

$\rightarrow$ Jordan, A., Schwartz, E., McGhie-Richmond, D. (2009), Preparing teachers for inclusive classrooms, "Teaching and Teacher Educatio", nr 25(4), s. 535-542.

$\rightarrow$ Karsten, S., Peetsma, T., Roeleveld, J., Vergeer, M. (2001), The Dutch policy of integration put to the test: differences in academic and psychosocial development of pupils in special and mainstream education, "European Journal of Special Needs Education", nr 16(3), s. 193-205.

$\rightarrow$ Karwowska, M. (2009), Problemy integracji w opinii kadry pedagogicznej [w:] Z. Janiszewska-Nieścioruk (red.), Problemy edukacji integracyjnej dzieci i młodzieży z niepełnosprawnościq intelektualnq, Kraków: Oficyna Wydawnicza Impuls, s. 157-169. 
$\rightarrow$ Kata, G. (2017), Wolontariat szkolny, Warszawa: Ośrodek Rozwoju Edukacji.

$\rightarrow$ Katz, J. (2014), Implementing the three block model of Universal Design for Learning: Effects on teachers' self-efficacy, stress and job satisfaction in inclusive classrooms K-12, „International Journal of Inclusive Education”, nr 19(1), s. 1-20.

$\rightarrow$ Kauffman, J.M., Hung, L.-Y. (2009), Special education for intellectual disability: Current trends and perspectives, "Current Opinion in Psychiatry", nr 22, s. 452-456.

$\rightarrow$ Kauffman, J.M., Mock Ward, D., Badar, J. (2016), The delusion of full inclusion [w:] R.M. Foxx, J.A. Mulick (red.), Controversial therapies for autism and intellectual disabilities, New York-London: Routledge, s. 71-86.

$\rightarrow$ Kaukiainen, A., Salmivalli, C., Lagerspetz, K., Tamminen, M., Vauras, M., Mäki, H., Poskiparta, E. (2002), Learning difficulties, social intelligence, and self-concept: Connections to bully-victim problems, "Scandinavian Journal of Psychology", nr 43(3), s. 269-278.

$\rightarrow$ Kawczyńska-Butrym, Z. (1998), Niepełnosprawność - specyfika pomocy społecznej, Katowice: Wydawnictwo Naukowe Śląsk.

$\rightarrow$ Kazanowski, Z. (2011), Przemiany pokoleniowe postaw wobec osób upośledzonych umysłowo, Lublin: Wydawnictwo UMCS.

$\rightarrow$ Kelley, K.R., Coco, C.M. (2015), Employment practices in a transition program for students with intellectual disabilities [w:] Way leads on to way. Paths to employment for people with intellectual disabilities, Washington DC: AAIDD.

$\rightarrow$ Kielin, J. (2012), Jak pracować z rodzicami dziecka upośledzonego, Gdańsk: Gdańskie Wydawnictwo Psychologiczne.

$\rightarrow$ Kielin, J., Klimek-Markiewicz, K. (2016), Krok po kroku, Gdańsk: Gdańskie Wydawnictwo Psychologiczne.

$\rightarrow$ Kijak, R. (2007), Obraz "innego" w percepcji i ocenie studentów kierunków pedagogicznych [w:] B. Jachimczak, B. Olszewska, D. Podgórska-Jachnik (red.), Miejsce Innego we współczesnych naukach o wychowaniu, Łódź: Satori, s. 229-230.

$\rightarrow$ Kim, J., Park, E., Snell. M.E. (2005), Impact of information and weekly contact on attitudes of Korean general educators and nondisabled students regarding peers with disabilities, „Mental Retardation”, t. 43, s. 401-415.

$\rightarrow$ Kirenko, J., Wawer, R. (2015), Dystans versus tolerancja. Percepcja niepełnosprawności w badaniach eyetrackingowych, Lublin: Wydawnictwo UMCS.

$\rightarrow$ Kirwil, L. (2004), Agresja szkolna jako rodzaj agresji proaktywnej [w:] A. Rejzner (red.), Agresja w Szkole. Spojrzenie wieloaspektowe, Warszawa: Wydawnictwo Wyższej Szkoły Pedagogicznej TWP, s. 7-24. 
$\rightarrow$ Kniveton, B.H. (2004), Adolescent perceptions of the importance of teachers as a therapeutic support in coping with their problems, "Emotional and Behavioural Differences", nr 9(4), s. 239-248.

$\rightarrow$ Knopik, T. (2018), Zafascynowani światem. Efektywne wspieranie rozwoju zdolności i zainteresowań uczniów w codziennej praktyce szkolnej, Warszawa: Ośrodek Rozwoju Edukacji.

$\rightarrow$ Komendant-Brodowska, A. (2011), Przemoc w szkole. Raport z badań, www.szkolabezprzemocy.pl [dostęp:14.02.2019].

$\rightarrow$ Komendant-Brodowska, A. (2014), Grupowe uwarunkowania przemocy szkolnej, bit.ly/2N89pHI [dostęp: 24.06.2019].

$\rightarrow$ Konarzewski, K. (2004), Nauczyciel [w:] K. Konarzewski (red.), Sztuka nauczania, t. II, Warszawa: Wydawnictwo Naukowe PWN.

$\rightarrow$ Konarzewski, K. (2011), Perspektywy indywidualizacji kształcenia. Raport o stanie badań, Warszawa: Instytut Badań Edukacyjnych.

$\rightarrow$ Kopp, C.B., Baker, B.L., Brown, K.W. (1992), Social skills and their correlates: Preschoolers with developmental delays, „American Journal of Mental Retardation", nr 96, s. 357-366.

$\rightarrow$ Kornaś, D. (2004), Relacje między dziećmi pełno- i niepełnosprawnymi w klasie integracyjnej w wieku wczesnoszkolnym [w:] G. Dryżałowska, H. Żuraw (red.), Integracja społeczna osób niepełnosprawnych, Warszawa: Wydawnictwo Akademickie „Żak", s. 302-312.

$\rightarrow$ Korzon, A. (2010), Uprzedzenia czy poczucie bezradności społeczności słyszących wobec "ciszy głuchych" [w:] A. Krause, K. Materny, J. Rzeźnicka-Krupa (red.), Życie z niepełnosprawnościq - wyzwania edukacyjne, rehabilitacyjne, normalizacyjne, Gdańsk: Wydawnictwo UG.

$\rightarrow$ Koutrouba, K., Vamvakari, M., Steliou, M. (2006), Factor correlated with teacher's attitudes towards the inclusion of students with special educational needs in Cyprus, „European Journal of Special Needs Education”, nr 21(4), s. 381-394.

$\rightarrow$ Kowalik, S. (1989), Upośledzenie umysłowe: teoria i praktyka rehabilitacji, Warszawa: Wydawnictwo Naukowe PWN.

$\rightarrow$ Kowalik, S. (2000), Rozwój społeczny [w:] B. Harwas-Napierała, J. Trempała, Psychologia rozwoju człowieka (t. 2), Warszawa: Wydawnictwo Naukowe PWN.

$\rightarrow$ Kowalik, S. (2003), Dorosłość osób niepełnosprawnych w świetle koncepcji strefy utraconego rozwoju [w:] K.D. Rzedzicka, A. Kobylańska (red.), Dorosłość, niepełnosprawność, czas wolny. Na pograniczach pedagogiki specjalnej, Kraków: Oficyna Wydawnicza Impuls. 
$\rightarrow$ Kozielecki, J. (2007), Psychotransgresjonizm. Nowy kierunek psychologii, Warszawa: Wydawnictwo Akademickie "Żak".

$\rightarrow$ Kozłowski, W., Matczak, E. (2012), Aspiracje edukacyjne rodziców dzieci z klas III szkoły podstawowej (raport z badań pilotażowych), Warszawa: Instytut Badań Edukacyjnych.

$\rightarrow$ Kożyczkowska, A., Młynarczuk-Sokołowska, A. (2018), Kulturowe konteksty dzieciństwa. Szkice antropologiczno-pedagogiczne, Gdańsk: Wydawnictwo Naukowe Katedra.

$\rightarrow$ Krajewski, J.J., Hyde, M.S. (2000), Comparison of teen attitudes toward individuals with mental retardation between 1987 and 1998: Has inclusion made a difference?, "Education and Training in Mental Retardation and Developmental Disabilities", nr 35(3), s. 284-293.

$\rightarrow$ Krakowiak, K. (2017), Założenia koncepcji diagnozy specjalnych potrzeb rozwojowych i edukacyjnych dzieci i młodzieży [w:] Diagnoza specjalnych potrzeb rozwojowych i edukacyjnych dzieci i młodzieży, Standardy, wytyczne oraz wskazówki do przygotowywania i adaptacji narzędzi diagnostycznych dla dzieci i młodzieży z wybranymi specjalnymi potrzebami rozwojowymi i edukacyjnymi, Warszawa: ORE, s. 11-18.

$\rightarrow$ Krasowicz-Kupis, G., Wiejak, K., Gruszczyńska, K. (2015), Katalog metod diagnozy rozwoju poznawczego dziecka na etapie edukacji przedszkolnej i wczesnoszkolnej, Warszawa: Instytut Badań Edukacyjnych.

$\rightarrow$ Kubicki, P., Dudzińska, A., Olcoń-Kubicka, M. (2012), Wszystko jasne - dostępność i jakość edukacji dla uczniów niepełnosprawnych. Raport z działań w 2011, Warszawa: Stowarzyszenie "Nie-Grzeczne Dzieci”.

$\rightarrow$ Kubicki, P., Grzelak, P., Orłowska, M. (2014), Realizacja badania ścieżek edukacyjnych niepełnosprawnych dzieci, uczniów i absolwentów - raport końcowy, Warszawa: Instytut Badań Edukacyjnych.

$\rightarrow$ Kubiczek, B. (2012), Projekt „Szkoła Demokracji-Szkoła Samorzq̨dności”. Kompetencje społeczne i obywatelskie uczniów i nauczycieli. Materiały dla uczestnika Konferencji, Sosnowiec: Sosnowieckie Centrum Edukacyjne „EDUKATOR”.

$\rightarrow$ Kulesza, E. (2002), Kształtowanie się społecznej pozycji ucznia ze specjalnymi potrzebami edukacyjnymi w pierwszej klasie integracyjnej [w:] E. Górniewicz, A. Krause (red.), Od tradycjonalizmu do ponowoczesności: dyskursy pedagogiki specjalnej, Olsztyn: UWM.

$\rightarrow$ Kurz, A., Elliott, S.N., Lemons, C.J., Zigmond, N., Kloo, A. (2014), Opportunity to learn: A differentiated opportunity structure for students with disabilities in general education classrooms, "Assessment for Effective Intervention", nr 40(1), s. 24-39. 
$\rightarrow$ Kwak, A. (1993), Rodzina jako środowisko wychowawcze [w:] T. Pilch, I. Lepalczyk, Pedagogika społeczna. Wychowanie i środowisko, Warszawa: Wydawnictwo Akademickie "Żak".

$\rightarrow$ Kwiatkowska, H. (1997), Edukacja nauczycieli. Konteksty, kategorie, praktyki, Warszawa: Instytut Badań Edukacyjnych, s. 52.

$\rightarrow$ Kwiatkowski, S.M. (2010), Miejsce i rola przywództwa w edukacji [w:] S.M. Kwiatkowski, J.M. Michalak (red.), Przywództwo edukacyjne w teorii i praktyce, Warszawa: Fundacja Rozwoju Systemu Edukacji, s. 13-23.

$\rightarrow$ Leary, M.R. (2011), Interpersonal rejection, New York: Oxford University Press.

$\rightarrow$ Lee, L.W., Low, H.M. (2013), 'Unconscious' inclusion of students with learning disabilities in a Malaysian mainstream primary school: Teachers' perspectives, "Journal of Research in Special Educational Needs", nr 13(3), s. 218-228.

$\rightarrow$ Lewicka-Zelent, A., Chimicz, D. (oprac.) (2018), Zaspokajanie potrzeb i respektowanie praw uczniów ze specjalnymi potrzebami edukacyjnymi (SPE) w ogólnodostępnej szkole podstawowej. Raport Rzecznika Praw Dziecka przygotowany na podstawie sondażu opinii rodziców, nauczycieli i dyrektorów szkół, Warszawa: Rzecznik Praw Dziecka.

$\rightarrow$ Lewowicki, T. (2008), O podstawowych warunkach pomyślnej pracy nauczycieli w sytuacji wielokulturowości [w:] T. Lewowicki, E. Ogrodzka-Mazur, A. Szczurek-Boruta (red.), Praca nauczyciela w warunkach wielokulturowości-studia i doświadczenia z pogranicza polsko-czeskiego, Toruń: Wydział Etnologii i Nauk o Edukacji Uniwersytetu Śląskiego, Wyższa Szkoła Pedagogiczna Związku Nauczycielstwa Polskiego w Warszawie.

$\rightarrow$ Leyser, Y., Kirk, R. (2004), Evaluating inclusion: An examination of parent views and factors influencing their perspectives, "International Journal of Disability, Development and Education", nr 51, s. 271-285.

$\rightarrow$ Liasidou, A., Svensson, C. (2014), Educating leaders for social justice: the case of special educational needs coordinators, „International Journal of Inclusive Education", nr 18(8), s. 78-79.

$\rightarrow$ Lifshitz, H., Glaubman, R., Issawi, R. (2004), Attitudes towards inclusion: the case of Israeli and Palestinian regular and special education teachers, „European Journal of Special Needs Education", nr 19(2), s. 171-190.

$\rightarrow$ Limont, W. (2011), Uczeń zdolny. Jak go rozpoznać i jak z nim pracować?, Gdańsk: Gdańskie Wydawnictwo Psychologiczne.

$\rightarrow$ Lipińska-Lokś, J. (2003), Psychospołeczna sytuacja dzieci z niepełnosprawnościq intelektualna w klasach integracyjnych [w:] Z. Janiszewska-Nieścioruk (red.), Człowiek z niepełnosprawnościq̨ intelektualnq, Kraków, Oficyna Wydawnicza Impuls, s. 249-256. 
$\rightarrow$ Lisowska, E. (2017), Zawodowe uwarunkowania zadowolenia z pracy wśród nauczycieli, „Forum Pedagogiczne”, nr 1, s. 227-243.

$\rightarrow$ Loebl, W. (2003), Drogi osiggania autonomii przez osoby niepełnosprawne [w:] K.D. Rzedzicka, A. Kobylańska (red.), Dorosłość, niepełnosprawność, czas wolny. Na pograniczach pedagogiki specjalnej, Kraków: Oficyna Wydawnicza Impuls.

$\rightarrow$ Loreman, T. (2007), Seven pillars of support for inclusive education: Moving from "Why?" to "How?", „International Journal of Whole Schooling”, nr 3(2), s. 22-38.

$\rightarrow$ Loreman, T., Sharma, U., Forlin, C. (2013), Do Pre-service Teachers Feel Ready to Teach in Inclusive Classrooms? A Four Country Study of Teaching Self-efficacy, "Australian Journal of Teacher Education”, nr 38(1), s. 27-44.

$\rightarrow$ Lundberg, K. (2015), Plusy i minusy integracji w szkołach ogólnodostępnych w Norwegii - materiały z międzynarodowej konferencji "Kształcenie uczniów z niepełnosprawnościami", Łódź.

$\rightarrow \quad$ Łaś, H. (2001), Wiedza nauczycieli szkół publicznych o kształceniu dzieci niepełnosprawnych [w:] D. Osik, A. Wojnarska (red.), Wspomaganie rozwoju uczniów ze specjalnymi potrzebami edukacyjnymi, Lublin: Wydawnictwo UMCS, s. $145-154$.

$\rightarrow$ Łobocki, M. (1985), Współdziałanie nauczycieli i rodziców w procesie wychowania, Warszawa: Wydawnictwo Nasza Księgarnia.

$\rightarrow$ Łobocki, M. (1993), Pedagogika wobec wartości [w:] B. Śliwerski, Kontestacje pedagogiczne, Kraków: Oficyna Wydawnicza Impuls.

$\rightarrow$ Maciarz, A. (1985), Stosunki społeczne między uczniami pełnosprawnymi i upośledzonymi umysłowo, [w:] J. Baran, J. Pilecki (red.), Wychowanie, kształcenie i przygotowanie do życia dzieci upośledzonych umysłowo. Materiały z konferencji naukowej, Kraków: Wydawnictwo WSP.

$\rightarrow$ Maciarz, A. (2005), Integracja edukacyjna w świetle doświadczeń i oczekiwań dzieci niepełnosprawnych [w:] W. Pilecka, A. Ozga, P. Kurtek (red.), Dziecko ze specjalnymi potrzebami edukacyjnymi w ekosystemie, Kielce: Wydawnictwo Akademii Świętokrzyskiej.

$\rightarrow$ Maliszewski, W.J. (2010), Komunikacja społeczna w szkole. Perspektywa jakości pracy szkoły i w szkole [w:] I. Nowosad, I. Mortag, J. Ondráková, Jakość życia i jakość szkoły. Wprowadzenie w zagadnienia jakości i efektywności pracy szkoły, Zielona Góra: Oficyna Wydawnicza UZ, bit.ly/2Kz6Zj5 [dostęp: 24.06.2019].

$\rightarrow$ Malinen, O.-P., Savolainen, H., Xu, J. (2012), Beijing in-service teachers' self-efficacy and attitudes towards inclusive education, "Teaching and Teacher Education", 28(4), s. 526-534.

$\rightarrow$ Marciniak-Paprocka, K. (2017), Rodzice o inkluzji-raport z badań pilotażowych, „Student Niepełnosprawny. Szkice i Rozprawy", nr 17(10), s. 135-157. 
$\rightarrow$ Markussen, E. (2004), Special education: does it help? A study of special education in Norwegian upper secondary schools, „European Journal of Special Needs Education", nr 19(1), s. 33-48.

$\rightarrow$ Marshall, S., Goessling, K., Young, R., Wozniak-Molnar, A. (2019), Researching the transition to high school for adolescents with a disability: qualitative action-project method as an exemplar approach, "International Journal of Disability, Development and Education", nr 66(4), s. 389-408.

$\rightarrow$ Marshall, S.K., Stainton, T., Wall, J.M., Zhu, M., Murray, J., Wu, S., El Bouhali, A., Parada, F., Zaidman Zait, A., Young, R.A. (2018), Transition to adulthood as a joint parent-youth project for young persons with intellectual and developmental disabilities, „Intellectual and Developmental Disabilities”, nr 56(4), s. 263-277.

$\rightarrow$ Marttinen, E.D., Dietrich, J., Almela-Aro, K. (2018), Intentional engagement in the transition to adulthood: An integrative perspective on identity, career, and goal developmental regulation, "European Psychologist”, nr 23(4), s. 311-323.

$\rightarrow$ Marzano, R.J. (2012), Sztuka i teoria skutecznego nauczania, Warszawa: Civitas.

$\rightarrow$ Mazza, J.J., Fleming, C.B., Abbott, R.D., Haggerty, K.P., Catalano, R.F. (2010), Identifying trajectories of adolescents' depressive phenomena: An examination of early factors, „Journal of Youth and Adolescence”, nr 39(6), s. 579-593.

$\rightarrow$ Mądrzycki, T. (1997), Psychologiczne prawidłowości kształtowania się postaw, Warszawa: Wydawnictwa Szkolne i Pedagogiczne.

$\rightarrow$ McLeskey, J., Waldron, N.L., Reed, L. (2014), A case study of a highly effective, inclusive elementary school, „Journal of Special Education”, nr 48(1), s. 59-70.

$\rightarrow$ McWilliam, R.A. (2010), Routines-based early intervention: supporting young children and their families, Baltimore: Brookes Publishing.

$\rightarrow$ Meissner-Łozińska, J. (2016), Instytucje i organizacje wspierajq̨ce dziecko i rodzinę [w:] U. Gruca-Mąsik (red.), Pomoc, opieka, wsparcie dziecka i rodziny, Rzeszów: Wydawnictwo Uniwersytetu Rzeszowskiego.

$\rightarrow$ Melosik, Z. (2007), Teoria i praktyka edukacji wielokulturowej, Kraków: Oficyna Wydawnicza Impuls.

$\rightarrow$ Mendel, M. (1998), Rodzice i szkoła. Jak współuczestniczyć w edukacji dzieci?, Toruń: Wydawnictwo Adam Marszałek.

$\rightarrow$ Meyer, A., Rose, D.H., Gordon, D. (2014), Universal design for learning: Theory and practice, Wakefield MA: CAST Professional Publishing.

$\rightarrow$ Mikrut, A. (2000), Próba wyjaśnienia zwiq̨zku między agresją i upośledzeniem umysłowym, "Roczniki Pedagogiki Specjalnej”, nr 11, s. 30-40.

$\rightarrow$ Minczakiewicz, E. (1993), Postawy społeczne uczniów szkół podstawowych wobec ich niepełnosprawnych rówieśników, "Kultura i Edukacja”, nr 3(5). 
$\rightarrow$ Mitchell, L.C., Hedge A.V. (2007), Beliefs and practices of in-service preschool teachers in inclusive settings: Implications for personel preparation, "Journal of early Childhood Teacher Education", nr 28(4), 353-366.

$\rightarrow$ Mitchell, D. (2014), What really works in special and inclusive education: Using evidence based teaching strategies, London: Routledge.

$\rightarrow$ Mitchell, D. (2016), Sprawdzone metody w edukacji specjalnej i włączającej, Gdańsk: Harmonia.

$\rightarrow$ Mittler, P. (2000), Czyje potrzeby? Czyje interesy? [w:] G. Fairbairn, S. Fairbairn (red.), Integracja dzieci o specjalnych potrzebach - wybrane zagadnienia etyczne, Warszawa: Centrum Metodyczne Pomocy Psychologiczno-Pedagogicznej MEN.

$\rightarrow$ Młynarczuk-Sokołowska, A., Szostak-Król, K. (2016), Uczniowie cudzoziemscy w Polskiej szkole - problemy, wyzwania i egzemplifikacje działań metodycznych [w:] E. Śmiechowska-Petrovskij (red.), Dzieci z trudnościami adaptacyjnymi w młodszym wieku szkolnym. Aspekty rozwojowe i edukacyjne w kontekście specyfiki różnic kulturowych, Warszawa: Wydawnictwo Naukowe Uniwersytetu Kardynała Stefana Wyszyńskiego w Warszawie.

$\rightarrow$ Morningstar, M.E. (2017), Transition to adulthood for youth with severe and multiple disabilities [w:] F.P. Orelove, D. Sobsey, D.L. Gilles (red.), Educating students with severe and multiple disabilities. A collaborative approach, Baltimore-London-Sydney: BROOKS Publishing Co.

$\rightarrow$ Moss C.M., Brookhart S.M. (2014), Cele uczenia się. Jak pomóc uczniom zrozumieć każdq lekcję, Warszawa: Stowarzyszenie ds. Nadzoru Szkolnego i Rozwoju Programów Nauczania, Centrum Edukacji Obywatelskiej, Ośrodek Rozwoju Edukacji, bit.ly/2ZDPz8u [dostęp: 24.06.2019].

$\rightarrow$ Muijs, D., Reynolds, D. (2003), The effectiveness of the use of learning support assistants in improving the mathematics achievement of low achieving pupils in primary school, „Educational Research”, nr 45(3), s. 219-230.

$\rightarrow$ Murzyn, A. (1999), Filozofia edukacji u schyłku XX wieku - wybrane kwestie, Kraków: Oficyna Wydawnicza Impuls.

$\rightarrow$ Myklebust, J.O. (2007), Diverging paths in upper secondary education: Competence attainment among students with special educational needs, "International Journal of Inclusive Education", nr 11(2), s. 215-231.

$\rightarrow$ Myśliwczyk, I. (2016), Inkluzja edukacyjna na etapie przedszkola w rozumieniu rodziców dzieci niepełnosprawnych, „Problemy wczesnej edukacji”, nr 2(33), s. $166-180$. 
$\rightarrow$ Nakken, H., Pijl, S.J. (2002), Getting along with classmates in regular schools: A review of the effects of integration on the development of social relationships, "International Journal of Inclusive Education", nr 6(1), s. 47-61.

$\rightarrow$ Nilholm, C., Alm. B. (2010), An inclusive classroom? A case study of inclusiveness, teacher strategies and children's experiences, „European Journal of Special Needs Education", nr 25(3), s. 239-252.

$\rightarrow$ Nukkarinen, A. (2010), From discrete to transformed? Developing inclusive primary school teacher education in a Finnish teacher education department, "Journal of Research in Special Educational Needs", nr 10(1), s. 185-196.

$\rightarrow$ Obuchowska, I. (2000), Adolescencja [w:] B. Harwas-Napierała, J. Trempała (red. nauk.), Psychologia rozwoju człowieka (t. 2), Warszawa: Wydawnictwo Naukowe PWN.

$\rightarrow$ Odom, S.L., Brown, W.H. (1993), Social interaction skills interventions for young children with disabilities in integrated settings [w:] C. Peck, S. Odom, D. Bricker (red.), Integrating young children with disabilities into community programs, Baltimore: Brookes Publishing, s. 39-64.

$\rightarrow$ Odom, S.L., McConnell, S.R., Chandler, L.K. (1994), Acceptability and feasibility of classroom-based social interaction interventions for young children with disabilities, „Exceptional Children”, nr 60, s. 226-236.

$\rightarrow$ Odom, S.L., McConnell, S.R., McEvoy, M.A., Peterson, C., Ostrosky, M., Chandler, L.K., Spicuzza, R.J., Skellenger, A., Creighton,M., Favazza P.C. (1999), Relative effects of interventions supporting the social competence of young children with disabilities, "Topics in Early Childhood Special Education”, nr 19(2), s. 75-91.

$\rightarrow$ Odom, S.L., Zercher, C., Li, S., Marquart, J., Sandall, S. (1998), Social relationships of preschool children with disabilities in inclusive settings. Paper presented at the Conference on Research Innovations in Early Intervention, Charleston, SC.

$\rightarrow$ OECD (2012), Equity and quality in education: Supporting disadvantaged students and schools, Paris: OECD Publishing, bit.ly/2r9urGG [dostęp: 24.09.2019].

$\rightarrow$ Oh-Young, C., Filler, J. (2015), A meta-analysis of the effects of placement on academic and social skill outcome measures of students with disabilities, „Research in Developmental Disabilities", nr 47, s. 80-92.

$\rightarrow$ Olechnowicz, H. (1979), Wychowywanie i nauczanie głębiej upośledzonych umysłowo, Warszawa: Wydawnictwa Szkolne i Pedagogiczne.

$\rightarrow$ Oleksy, J., Cabała, A. (2009), Integralne wychowanie i nauczanie jako podłoże kształtowanie postaw wobec uczniów niepełnosprawnych - refleksje na temat czynności nauczyciela [w:] Z. Gajdzica (red.), Społeczne i edukacyjne uwarunkowania rozwoju oraz funkcjonowania dzieci i młodzieży z niepełnosprawnościq, Kraków: Oficyna Wydawnicza Impuls, s. 127-137. 
$\rightarrow$ Oleńska-Pawlak, T. (1992), Warunki realizacji funkcji opiekuńczej i wychowawczej w szkołach masowych wobec dzieci z zaburzeniami w stanie zdrowia i rozwoju [w:] A. Hulek, B. Grochmal-Bach (red.), Uczeń niepełnosprawny w szkole masowej, Kraków: Wydawnictwo WSP.

$\rightarrow$ Olweus, D. (2007), Mobbing. Fala przemocy w szkole. Jak ja powstrzymać?, Warszawa: Jacek Santorski \& Co.

$\rightarrow$ Ostrowska, A. (2003), Kompetencje społeczne osób niepełnosprawnych - bariery społeczne [w:] K.D. Rzedzicka, A. Kobylańska (red.), Dorosłość, niepełnosprawność, czas wolny. Na pograniczach pedagogiki specjalnej, Kraków: Oficyna Wydawnicza Impuls.

$\rightarrow$ Oszustowicz, B. (2004), Obraz osoby niepełnosprawnej w świadomości dzieci sześcioletnich z przedszkolnej grupy integracyjnej [w:] G. Dryżałowska, H. Żuraw (red.), Integracja społeczna osób niepełnosprawnych, Warszawa: Wydawnictwo Akademickie "Żak", s. 274-285.

$\rightarrow$ Otrębski, W. (2018), Niepełnosprawność - wybrane problemy i definicje [w:] E. Rutkowska (red.), Rehabilitacja i pielęgnowanie osób niepełnosprawnych, Warszawa: Wydawnictwo Lekarskie PZWL.

$\rightarrow$ Otrębski, W., Wiącek, G., Domagała-Zyśk, E., Sidor-Piekarska B. (2012), Jestem dorosły-chcę pracować. Program wspierający młodzież z niepełnosprawnościq umysłową w procesie przejścia z edukacji do rynku pracy, Lublin: Europerspektywa.

$\rightarrow$ Owieczko, K., Łangowski, I. (2013), Rodzice jako partnerzy w procesie rehabilitacji dziecka niepełnosprawnego [w:] Z. Janiszewska-Nieścioruk (red.), Człowiek z niepełnosprawnościq intelektualnq, t. 1: Wybrane problemy osobowości, rodzin i edukacji osób z niepełnosprawnościq intelektualnq̨, Kraków: Oficyna Wydawnicza Impuls.

$\rightarrow$ Palak, Z. (2000), Uczniowie niewidomi i słabowidzq̨cy w szkołach ogólnodostępnych, Lublin: Wydawnictwo UMCS.

$\rightarrow$ Palak, Z. (2012), Dystans społeczny wobec osób z różnym rodzajem niepełnosprawności - wczoraj i dziś [w:] M. Parchomiuk, B. Szabała (red.), Dystans społeczny wobec osób z niepełnosprawnościq jako problem pedagogiki specjalnej, Lublin: Wydawnictwo UMCS.

$\rightarrow$ Paliokosta, P., Blandford, S. (2010), Inclusion in school: A policy, ideology or lived experience? Similar findings in diverse school cultures, „British Journal of Learning Support", nr 25(4), s. 179-186.

$\rightarrow$ Palmer, D.S., Fuller, K., Arora, T., Nelson, M. (2001), Taking sides: Parents' views on inclusion for their children with severe disabilities, "Exceptional Children", nr 67(4), s. 467-484. 
$\rightarrow$ Paluchowski, W.J. (2007), Diagnoza psychologiczna. Proces - narzędzia-standardy, Warszawa: Wydawnictwa Akademickie i Profesjonalne.

$\rightarrow$ Pańczyk, J. (1990), Analiza orzeczeń o upośledzeniu umysłowym wydawanych przez poradnie wychowawczo-zawodowe [w:] J. Pańczyk (red.), Współczesne problemy Pedagogiki Specjalnej - Materiały z sesji organizowanych w latach 1985-1988, Warszawa: Wydawnictwo WSPS.

$\rightarrow$ Paniasiuk, J. (2017), Etapy diagnozy dziecka ze specjalnymi potrzebami edukacyjnymi [w:] K. Krakowiak (red.), Diagnoza specjalnych potrzeb rozwojowych i edukacyjnych dzieci i młodzieży. Standardy, wytyczne oraz wskazówki do przygotowywania i adaptacji narzędzi diagnostycznych dla dzieci i młodzieży z wybranymi specjalnymi potrzebami rozwojowymi i edukacyjnymi, Warszawa: ORE, s. 45-57.

$\rightarrow$ Papuda-Dolińska, B. (2017), Dziecko z niepełnosprawnościq wzroku w roli ucznia szkoły ogólnodostępnej, integracyjnej i specjalnej, Lublin: Wydawnictwo UMCS.

$\rightarrow$ Parys, K. (2007), Problemy integracji szkolnej w badaniach empirycznych przegląd materiałów pokonferencyjnych [w:] Z. Janiszewska-Nieścioruk (red.), Problemy edukacji dzieci i młodzieży z niepełnosprawnościq intelektualna, Kraków: Oficyna Wydawnicza Impuls.

$\rightarrow$ Pasikowski, T. (2000), Stres i zdrowie: problemy - kierunki - kontrowersje, Poznań: Wydawnictwo Fundacji Humaniora.

$\rightarrow$ Peck, C.A., Staub, D., Gallucci, C., Schwartz, I. (2004), Parent perceptions of the impacts of inclusion on their nondisabled child, "Research and Practice for Persons with Severe Disabilities", nr 29(2), s. 135-143.

$\rightarrow$ Peetsma, T., Vergeer, M., Roeleveld, J., Karsten, S. (2001), Inclusion in education: Comparing pupils' development in special and regular education, „Educational Review", nr 52(2), s. 125-135.

$\rightarrow$ Peltopuro, M., Ahonen, T., Kaartinen, J., Seppälä, H., Närhi, V. (2014), Bordeline intellectual functioning: A systematic literature review, "Intellectual and Developmental Disabilities", nr 52, s. 419-443.

$\rightarrow$ Petty, G. (2017), Nowoczesne nauczanie. Praktyczne wskazówki i techniki dla nauczycieli, wykładowców i szkoleniowców, Gdańsk: Gdańskie Wydawnictwo Psychologiczne.

$\rightarrow$ Pfeiffer, S., Shaunessy-Dedrick, E., Foley-Nicpon, M. (2018), APA Handbook of Giftedness and Talent, Washington: APA.

$\rightarrow$ Piotrowicz, R., Wieloprofilowa diagnoza małego dziecka. Wskazania dla specjalistów i rodziców małych dzieci z symptomami zaburzeń rozwojowych, bit.ly/2N8itMy [dostęp: 24.06.2019]. 
$\rightarrow$ Pisha, B., Coyne, P. (2001), Smart from the start: The promise of Universal Design for Learning , „Remedial and Special Education”, nr 22(4), s. 197-203.

$\rightarrow$ Piwowarski, R. (2015), Rozwój zawodowy nauczycieli [w:] K. Hernik (red.), Polscy nauczyciele i dyrektorzy w Międzynarodowym Badaniu Nauczania i Uczenia się, TALIS 2013, Warszawa: Instytut Badań Edukacyjnych.

$\rightarrow$ Plichta, P. (2010), Uczniowie niepełnosprawni intelektualnie jako ofiary i sprawcy agresji rówieśniczej [w:] J. Pyżalski (red.), Bullying a specjalne potrzeby edukacyjne-podręcznik metodyczny, Łódź: ROBUSD Wyższa Szkoła Pedagogiczna w Łodzi, Centrum Badań Behawioralnych Uniwersytetu Stavanger.

$\rightarrow$ Plichta, P. (2016), Przemoc rówieśnicza i uczniowie ze specjalnymi potrzebami edukacyjnymi - uwarunkowania i propozycje rozwiqzań profilaktycznych, „Dziecko Krzywdzone. Teoria, badania, praktyka", nr 15(1), s. 28-52.

$\rightarrow$ Plichta, P., Olempska-Wysocka, M. (2013), Narażenie na agresję rówieśniczq niepełnosprawnych uczniów szkół integracyjnych w relacjach nauczycieli wspomagających, "Studia Edukacyjne”, nr 28, s. 169-189.

$\rightarrow$ Plichta, P., Olempska-Wysocka, M. (2014), Agresja rówieśnicza wobec uczniów ze specjalnymi potrzebami edukacyjnymi w relacjach pracowników poradni psychologiczno-pedagogicznych, „Studia Edukacyjne”, nr 33, s. 201-225.

$\rightarrow$ Podgórska-Jachnik, D. (2007), Pedagogika specjalna jako pedagogika wielokulturowa - pedagogika wielokulturowa jako pedagogika specjalna [w:] T. Żółkowska (red.), Pedagogika specjalna - koncepcje i rzeczywistość. Konteksty pedagogiki specjalnej, t. II, Szczecin: Print Group Daniel Krzanowski.

$\rightarrow$ Poraj, G. (2009), Od pasji do frustracji. Modele psychologicznego funkcjonowania nauczycieli, Łódź: Wydawnictwo Uniwersytetu Łódzkiego.

$\rightarrow$ Powell, J. (2011), Barriers to inclusion. Special education in the United States and Germany, Boulder-London: Paradigm Publishers.

$\rightarrow$ Pyżalski, J. (2012), Agresja elektroniczna i cyberbullying jako ryzykowne zachowanie młodzieży, Kraków: Oficyna Wydawnicza Impuls.

$\rightarrow$ Pyżalski, J. (2018), Przeciwdziałanie przemocy rówieśniczej w szkole - krytyczny przegląd stosowanych rozwiqzań, „Dziecko Krzywdzone. Teoria, badania, praktyka", nr 17(1), s. 30-45.

$\rightarrow$ Pyżalski, J., Podgórska-Jachnik, D. (red.) (2015), Raport końcowy-Badanie potrzeb i satysfakcji z wybranych usług skierowanych do rodzin z dziećmi z orzeczonq niepełnosprawnościq $w$ wieku 8-16 lat, bit.ly/2KyY1T7 [dostęp: 24.06.2019].

$\rightarrow$ Rakap, S., Kaczmarek, L. (2010), Teachers' attitudes towards inclusion in Turkey, „European Journal of Special Needs Education”, nr 25(1), s. 59-74. 
$\rightarrow$ Rao, K., Meo, G. (2016), Using Universal Design for Learning to design standards-based lessons, "SAGE Open”, nr 4(6), s. 1-12.

$\rightarrow$ Rao, K., Ok, M.W., Bryant, B.R. (2014), A review of research on universal design educational models, „Remedial and Special Education”, nr 3 (35), s. 153-166.

$\rightarrow$ Rapp, W.H. (2014), Universal Design for Learning in Action. 100 ways to teach all learners, Baltimore: Brookes Publishing.

$\rightarrow$ Raskauskas, J., Modell, S. (2011), Modifying Anti-Bullying Programs to Include Students with Disabilities, „Teaching Exceptional Children”, nr 44(1), s. 60-67.

$\rightarrow$ Reiter, S., Lapidot-Lefler, N. (2007), Bullying among special education students with intellectual disabilities: differences in social adjustment and social skills, "Intellectual and Developmental Disabilities", nr 45(3), s. 174-181.

$\rightarrow$ Renzulli, J. (2003), Conception of giftedness and its relationship to the development of social capital [w:] N. Colangelo, G. Davis (red.), Handbook of gifted education, Boston: Pearson Education, s. 75-87.

$\rightarrow$ Rigby, D. (2010), Przemoc w szkole. Jak jq ograniczać. Poradnik dla rodziców i pedagogów, Kraków: Wydawnictwo Uniwersytetu Jagiellońskiego.

$\rightarrow$ Rola, B. (2011), Działania wspierajq̨ce rozwój dziecka z lekkq niepełnosprawnościq intelektualna [w:] J. Godkowska (red.), Uczeń ze specjalnymi potrzebami edukacyjnymi w szkole ogólnodostępnej, Warszawa: Wydawnictwo APS, s. 217-231.

$\rightarrow$ Rola, B., Mrozińska, M. (2016), Raport dotyczq̨cy wdrażania art. 24 Konwencji o Prawach Osób Niepełnosprawnych w Polsce Opracowany w Ramach Projektu "Wdrażanie Konwencji o Prawach Osób Niepełnosprawnych - Wspólna Sprawa", Warszawa: PFON.

$\rightarrow$ Rose, C.A., Monda-Amaya, L.E. (2011), Bullying and victimization among students with disabilities: Effective strategies for classroom teachers, "Intervention in School and Clinic", nr 48(2), s. 99-107.

$\rightarrow$ Ross-Hill, R. (2009), Teacher attitude towards inclusion practices and special needs students, "Journal of Research in Special Educational Needs", nr 9(3), s. $188-198$.

$\rightarrow$ Rożnowski, B. (2009), Przechodzenie młodzieży z systemu edukacji na rynek pracy w Polsce. Analiza kluczowych pojęć, Lublin: Wydawnictwo KUL.

$\rightarrow$ Rudek, I. (2005), Tolerancja wobec dzieci niepełnosprawnych rówieśników, „Auxilium Sociale. Wsparcie społeczne", nr 1.

$\rightarrow$ Ruijs, N.M., Peetsma, T.T.D. (2009), Effects of inclusion on students with and without special educational needs reviewed, "Educational Research Review", nr 4(2), s. 67-79. 
$\rightarrow$ Rutkowski, P., Mostowski, P. (2017), Podręczniki w polskim języku migowym (PJM) jako narzędzie surdopedagoga, "Annales Universitatis Paedagogicae Cracoviensis. Studia Paedagogica", nr 8 (fol. 241), s. 93-111.

$\rightarrow$ Rutkowski, P., Mostowski, P. (2018), Multimedialne adaptacje podręczników z serii Nasz elementarz i Nasza szkoła jako pomoc w nauczaniu polskiego języka migowego (PJM), „Forum Oświatowe”, t. 30, nr 2(60), s. 245-266.

$\rightarrow$ Rzedzicka, K.D. (2003), Społeczne koncepcje dorosłości a niepełnosprawność [w:] K.D. Rzedzicka, A. Kobylańska (red.), Dorosłość, niepełnosprawność, czas wolny. Na pograniczach pedagogiki specjalnej, Kraków: Oficyna Wydawnicza Impuls.

$\rightarrow$ Rzedzicka, K.D., Kobylańska, A. (red.) (2003), Dorosłość, niepełnosprawność, czas wolny. Na pograniczach pedagogiki specjalnej. Kraków: Oficyna Wydawnicza Impuls, s. 69-73.

$\rightarrow$ Sajdera, J. (2016), Uczenie się w kontekście społecznym - tutoring rówieśniczy jako sposób wspierania zdolności społeczno-poznawczych dzieci w sytuacjach interakcyjnych, „Pedagogika Przedszkolna i Wczesnoszkolna”, nr 42, s. 81-91.

$\rightarrow$ Sakowicz-Boboryko, A. (2003), Uczeń z wadq słuchu w środowisku słyszq̨cych rówieśników szkolnych [w:] Z. Kazanowski, D. Osik-Chudowolska (red.), Integracja osób niepełnosprawnych w edukacji i integracjach społecznych, Lublin: Wydawnictwo UMCS.

$\rightarrow$ Salmivalli, C. (2010), Bullying and the peer group: A review, „Aggresion and Violent Behaviour", nr 15(2), s. 112-120.

$\rightarrow$ Schalock, R., Borthwick-Duffy, S., Bradley, V., Buntinx, W., Coulter, D., Craig, E. i in. (2010), Intellectual disability: Definition, classification, and systems of support (11th ed.), Washington: American Association on Intellectual and Developmental Disabilities.

$\rightarrow$ Scruggs, T.L., Mastropieri, M.A. (1996), Teacher perceptions of mainstream/ inclusion, 1958-1995, „Eceptional Children”, nr 63(1), s. 59-74.

$\rightarrow$ Sęk, H., Czabała, C. (2000), Pomoc psychologiczna, [w:] J. Strelau (red.) Psychologia. Podręcznik akademicki, t. 3, Gdańsk: Gdańskie Wydawnictwo Psychologiczne.

$\rightarrow$ Sękowski, A. (2001), Osiągnięcia uczniów zdolnych, Lublin: Wydawnictwo KUL.

$\rightarrow$ Sermier Dessemontet, R., Bless, G., Morin, D. (2012), Effects of inclusion on the academic achievement and adaptive behaviour of children with intellectual disabilities, „Journal of Intellectual Disability Research", nr 56(6), s. 579-587.

$\rightarrow$ Sharma, U., Loreman, T., Forlin, Ch. (2011), Measuring teacher efficacy to implement inclusive practices, „Journal of Research in Special Educational Needs", nr 12(1), s. 12-21. 
$\rightarrow$ Sijtsema, J.J., Veenstra, R., Lindenberg, S., Salmivalli, C. (2009), Empirical test of bullies' status goals: Assessing direct goals, aggression, and prestige, "Aggressive Behaviour", nr 35, s. 57-67.

$\rightarrow$ Śliwerski, B. (2016), Nadszedł czas rodziców, „Psychologia w Szkole”, nr 1.

$\rightarrow$ Smith, M.K., Smith, K.E. (2000), "I believe in inclusion, but...": Regular education early childhood teachers' perceptions of successful inclusion, "Journal of Research in Childhood Education", nr 14(2), s. 161-180.

$\rightarrow$ Smogorzewska, J. (2019), Środowisko szkolne a rozwój teorii umysłu u dzieci w młodszym wieku szkolnym, Warszawa: Wydawnictwo Naukowe PWN.

$\rightarrow$ Smogorzewska, J., Szumski, G. (2015), Rozwijanie kompetencji społecznych dzieci przedszkolnych. Teoria, metodyka, efekty, Warszawa: Wydawnictwo Naukowe PWN.

$\rightarrow$ Sochańska-Kawiecka, M., Makowska-Belta, E., Milczarek, D., Morysińska, A., Zielińska, D.A. (2015), Włączajq̨cy system edukacji i rynku pracy-rekomendacje dla polityki publicznej. Raport końcowy, Warszawa: Instytut Badań Edukacyjnych.

$\rightarrow$ Solis, M., Vaughn, S., Swanson, E., McCulley, L. (2012), Collaborative models of instruction: The empirical foundations of inclusion and co-teaching , "Psychology in the Schools", nr 49(5), s. 498-510.

$\rightarrow$ Sołtysiak, T., Łabuć-Kryska, I., Budrewicz, I. (1995), Postawy młodzieży szkół ponadpodstawowych wyrażane w opiniach i poglądach wobec dzieci odbiegajacych od normy [w:] M. Chodkowska (red.), Dziecko niepełnosprawne w rodzinie. Socjalizacja i rehabilitacja, Lublin: Wydawnictwo UMCS.

$\rightarrow$ Sowińska, A. (2014), Zadowolenie z pracy-problemy definicyjne „Studia Ekonomiczne", t. 197, s. 45-56.

$\rightarrow$ Spratt, J., Florian, L. (2014), Developing and using a framework for gauging the use of inclusive pedagogy by new and experienced teachers [w:] C. Forlin, T. Loreman (red.), Measuring Inclusive Education (International Perspectives on Inclusive Education, t. 3), Bingley: Emerald Group Publishing Limited.

$\rightarrow$ Spicuzza, R.J., Skellenger, A., Favazza, P.C. (1999), Relative Effects of Interventions, „Special Education”, nr 21, s. 162-175.

$\rightarrow$ Spławiec, M. (2002), Stosunek warszawskiej młodzieży licealnej do osób niepełnosprawnych, „Niepełnosprawność i Rehabilitacja”, nr 2, s. 21-43.

$\rightarrow$ Sroczyński, W. (2015), Pedagodzy wobec rodziny [w:] W. Sroczyński, Rodzina w świetle wybranych kwestii społecznych, Siedlce: Pracownia Wydawnicza Wydziału Humanistycznego Uniwersytetu Przyrodniczo-Humanistycznego w Siedlcach. 
$\rightarrow$ Stemplewska-Żakowicz, K. (2008), Diagnoza psychologiczna. Diagnozowanie jako kompetencja profesjonalna, Gdańsk: Gdańskie Wydawnictwo Psychologiczne.

$\rightarrow$ Sterna, D. (2014), Uczę (się) w szkole, Warszawa: Centrum Edukacji Obywatelskiej, Ośrodek Rozwoju Edukacji, bit.ly/2Lbrou8 [dostęp: 24.06.2019].

$\rightarrow$ Sterna, D. (2016), Uczę się uczyć. Ocenianie kształtujq̨ce w praktyce, Warszawa: Centrum Edukacji Obywatelskiej.

$\rightarrow$ Sternberg, R. (1996), Successful intelligence: How practical and creative intelligence determine success in life, New York: Simon\&Schuster.

$\rightarrow$ Sudar-Malukiewicz, J. (2001), Nauczyciele szkół specjalnych i masowych wobec integracji społecznej osób upośledzonych umysłowo [w:] A. Maciarz, Z. Janiszewska-Nieścioruk, H. Ochonczenko (red.), Człowiek niepełnosprawny w rodzinie i w środowisku lokalnym, Zielona Góra: Lubuskie Towarzystwo Naukowe, s. 309-318.

$\rightarrow$ Swann, M., Peacock, A., Hart, S., Drummond, M.J. (2012), Creating Learning without Limits, Maidenhead: Open University Press.

$\rightarrow$ Suter, J.C., Giangreco, M.F. (2009), Numbers that count: Exploring special education and paraprofessional service delivery in inclusion-oriented schools, „Journal of Special Education", nr 43(2), s. 81-93.

$\rightarrow$ Szczupał, B. (2009), Godność osoby z niepełnosprawnościq. studium teoretyczno-empiryczne poczucia godności młodzieży z dysfunkcja narzq̨du ruchu, Warszawa: Wydawnictwo Naukowe AKAPIT.

$\rightarrow$ Sztompka, P. (2004), Socjologia, Kraków: Społeczny Instytut Wydawniczy „Znak".

$\rightarrow$ Szumilas, E., Czopińska, M. (2015), Model Lokalnej Współpracy na rzecz dzieci ze specjalnymi potrzebami edukacyjnymi, Warszawa: Ośrodek Rozwoju Edukacji.

$\rightarrow$ Szumski, G. (2010), Wokół edukacji włączajq̨cej. Efekty kształcenia uczniów z niepełnosprawnościq intelektualng $w$ stopniu lekkim w klasach specjalnych, integracyjnych i ogólnodostępnych, Warszawa: Wydawnictwo APS.

$\rightarrow$ Szumski, G. (2011), Teoretyczne implikacje edukacji włączajq̨cej [w:] Z. Gajdzica (red.), Uczeń z niepełnosprawnościq w szkole ogólnodostępnej, Sosnowiec: Oficyna Wydawnicza "Humanitas".

$\rightarrow$ Szumski, G., Karwowski, M. (2014), Psychosocial functioning and school achievement of children with mild intellectual disability in Polish special, integrative and mainstream schools, "Journal of Policy and Practice in Intellectual Disabilities", nr 11(2), s. 99-108.

$\rightarrow$ Szumski, G., Firkowska-Mankiewicz, A., Lebuda, I., Karwowski, M. (2018), Predictors of success and quality of life in people with borderline intelligence: 
The special school label, personal and social resources, "Journal of Applied Research in Intellectual Disabilites", nr 31(6), s. 1021-1031.

$\rightarrow$ Szwed, S. (2012), Sumienie bardzo czyste [w:] J. Koral (red.), Pytania, których się nie zadaje. 12 reporterów. 12 ważnych odpowiedzi, Warszawa: Stowarzyszenie Rodzin i Opiekunów Osób z Zespołem Downa Bardziej Kochani.

$\rightarrow$ Szymański, M.J. (1998), Młodzież wobec wartości, Warszawa: Wydawnictwo Instytutu Badań Edukacyjnych.

$\rightarrow$ Tarwacki, M. (2011), Edukacja włączajq̨ca w szkole w Łajskach, "Meritum”, nr 1(20), s. 51.

$\rightarrow$ Tarwacki, M. (2015), Wyjq̨tkowi uczniowie w wyjq̨tkowej szkole - doświadczenia Zespołu Szkół w Łajskach, Warszawa: Ośrodek Rozwoju Edukacji.

$\rightarrow$ Taylor, R.L., Smiley, L.R., Richards, S.B. (2009), Exceptional students: Preparing teachers for the 21st century, New York: McGraw-Hill.

$\rightarrow$ TEAL (2010), TEAL Center fact sheet no. 2: Fact sheet: Universal Design for Learning, bit.ly/2Xo94VI [dostęp: 18.02.2019].

$\rightarrow$ The Future of Jobs Report (2018), bit.ly/2xi2OQB [dostęp:15.02.2019].

$\rightarrow$ Timmons J.C., Fesko S.L., Zalewska A. (2015), Considering community service during transition to employment for youth with intellectual and developmental disabilities [w:] Way leads on to way. Paths to employment for people with intellectual disabilities, Washington: AAIDD.

$\rightarrow$ Tomaszewska, A. (2002), Holenderski model edukacji i rehabilitacji osób słabo widzq̨cych i niewidomych, "Szkoła Specjalna”, nr 1, s. 50-56.

$\rightarrow$ Trempała, J. (2000), Modele rozwoju psychicznego, Bydgoszcz: Wydawnictwo Uczelniane Akademii Bydgoskiej.

$\rightarrow$ Twardowski, A. (2002), Kształtowanie dialogowej kompetencji komunikacyjnej u uczniów niepełnosprawnych intelektualnie, Kalisz-Poznań: Instytut Pedagogiczno-Artystyczny UAM.

$\rightarrow$ Twardowski, A. (2005), Sytuacja rodzin dzieci niepełnosprawnych [w:] I. Obuchowska (red.), Dziecko niepełnosprawne w rodzinie, Warszawa: Wydawnictwa Szkolne i Pedagogiczne.

$\rightarrow$ Twardowski, A. (2009), Dylematy integracyjnego kształcenia dzieci i młodzieży z niepełnosprawnościq [w:] Z. Janiszewska-Nieścioruk (red.), Problemy edukacji integracyjnej dzieci i młodzieży z niepełnosprawnościq̨ intelektualnq, Kraków: Oficyna Wydawnicza Impuls.

$\rightarrow$ Twardowski, A. (2012), Wczesne wspomaganie rozwoju dzieci z niepełnosprawnościami w środowisku rodzinnym, Poznań: Wydawnictwo Naukowe UAM.

$\rightarrow$ Tyszkowa, M. (1997), Zadania rozwojowe [w:] W. Pomykało (red.), Encyklopedia pedagogiczna, Warszawa: Fundacja „Innowacja”. 
$\rightarrow$ Sibińska, A. (2018), Uberyzacja, czyli ekonomia na żądanie. Nowe zjawisko społeczno-ekonomiczne, (wywiad z Anną Sibińską, ekspertką Polsko-Amerykańskiego Centrum Zarządzania Uniwersytetu Łódzkiego), bit.ly/2YbyhiE [dostęp: 1.02.2019].

$\rightarrow$ Uczeń ze specjalnymi potrzebami edukacyjnymi bank dobrych praktyk (Ośrodek Rozwoju Edukacji), bit.ly/2KZthKx [dostęp: 24.06.2019].

$\rightarrow$ Uczniowie ze specjalnymi potrzebami edukacyjnymi według województw W roku szkolnym 2017/2018 wg SIO, stan na 30.09.2017 (zakładka „Szkoły ogólnodostępne"), bit.ly/2laTQIp [dostęp: 13.02.2019].

$\rightarrow$ UNESCO-IBE (2008), Conclusions and recommendations of the 48th session of the International Conference on Education (ED/BIE/CONFINTED 48/5), Geneva: UNESCO IBE.

$\rightarrow$ Vaughn, S., Gersten, R., Chard, D.J. (2000), The underlying message in LD intervention research: Findings from research syntheses, "Exceptional Children”, nr 1, s. 99-114.

$\rightarrow$ Vitaro, F., Brendgen, M., Larose, S., Tremblay, R.E. (2005), Kindergarten disruptive behaviours, protective factors, and educational achievement by early adulthood, "Journal of Educational Psychology", nr 97, s. 617-629.

$\rightarrow$ Wachowiak, A. (1992), Błędy nauczycieli szkół masowych w postępowaniu z dziećmi niepełnosprawnymi [w:] A. Hulek, B. Grochmal-Bach (red.), Uczeń niepełnosprawny w szkole masowej, Kraków: Wydawnictwo WSP.

$\rightarrow$ Walczak, R. (2014), Podstawy zarzq̨dzania projektami metody i przykłady, Warszawa: Difin.

$\rightarrow$ Walczak, W. (2011), Zarzq̨dzanie różnorodnościq jako podstawa budowania potencjału kapitału ludzkiego organizacji, „E-mentor”, nr 3(40), s. 16.

$\rightarrow$ Wang, M.C., Baker, E.T. (1985/1986), Mainstreaming programs: Design features and effects, "The Journal of Special Education", nr 19(4), s. 503-521.

$\rightarrow$ Warnken, G. (1997), Kultura szkoły, rozwój organizacyjny, doskonalenie - rozważania na temat reformy szkolnej [w:] Z. Radwan (red.), Rozwój organizacyjny szkoły. Antologia 3, Warszawa: Ministerstwo Edukacji Narodowej, s. 75.

$\rightarrow$ Watkins, A., Donnelly, V. (w druku), Connecting research and classroom practice to promote inclusive education - policy implications [w:] M.A. Peters (red.), Encyclopedia of Teacher Education, New York: Springer.

$\rightarrow$ Westwood, P. (2013), Inclusive and adaptative teaching: Meeting the challenge of diversity in classroom, New York: Routledge.

$\rightarrow$ Whitney, S. (2011), No child behind..., Harbour: House Law Press.

$\rightarrow$ Wiącek, G. (2005), Pomiar efektywności kształcenia integracyjnego dzieci ze specjalnymi potrzebami edukacyjnymi [w:] Cz. Kosakowski, A. Krause (red.), 
Normalizacja środowisk życia osób niepełnosprawnych, Olsztyn: Wydawnictwo UWM.

$\rightarrow$ Will, M. (1984), OSERS Programming for the transition of the youth $w$ disability. Bridges from school to working life, Washington DC: OSERRS-US Office Education.

$\rightarrow$ Włodarski, Z. (2014), Psychologia nauczania [w:] M. Przetacznik-Gierowska, Z. Włodarski, Psychologia wychowawcza, t. 1, Warszawa: Wydawnictwo Naukowe PWN.

$\rightarrow$ Wojciszke, B. (2000), Postawy i ich zmiana [w:] J. Strelau (red.) Psychologia. Podręcznik akademicki. Jednostka w społeczeństwie i elementy psychologii stosowanej, t. 3, Gdańsk: Gdańskie Wydawnictwo Psychologiczne, s. 79-106.

$\rightarrow$ World Health Organization (2015), The European Mental Health Action Plan 2013-2020, Copenhagen: World Health Organization.

$\rightarrow$ Zalewska, A. (2009), Wiek, płeć i stanowisko pracy a zadowolenie z życia, „Psychologia Jakości Życia”, t. 8, nr 1, s. 1-20.

$\rightarrow$ Żejmis, M., Jurga, L.I. (2016), Pogłębiona analiza danych pozyskanych w badaniu jakościowym [w:] Wdrażanie Konwencji o prawach osób niepełnosprawnych - wspólna sprawa, Warszawa: Kantar Millward Brown.

$\rightarrow$ Żywanowska, A. (2009), Agresja u osób z lekkq̨ niepełnosprawnościq̨ intelektualnq. Wielowymiarowość uwarunkowań, Kraków: Oficyna Wydawnicza Impuls. 


\section{Dokumenty}

$\rightarrow$ Council conclusions of 26 November 2009 on the education of children with a migrant background, "Official Journal of the European Union", t. 52, 11.12.2009, bit.ly/2X1IFNo [dostęp: 22.06.2019].

$\rightarrow$ Deklaracja z Salamanki oraz Wytyczne dla Działań w Zakresie Specjalnych Potrzeb Edukacyjnych (1994), bit.ly/2WTZ8hW [dostęp: 22.06.2019].

$\rightarrow$ ICF-Międzynarodowa Klasyfikacja Funkcjonowania, Niepełnosprawności i Zdrowia (2012), Warszawa: CSI OZ, bit.ly/2ERzK6c [dostęp: 24.06.2019].

$\rightarrow$ Informacja Rzecznika Praw Obywatelskich o działaniach podjętych przez Rzeczpospolitą Polską w celu implementacji postanowień Konwencji o prawach osób niepełnosprawnych w latach 2015-2017, bit.ly/2ZPtjsB [dostęp: 24.06.2019].

$\rightarrow \quad$ Konstytucja RP z dnia 2 kwietnia 1997 r. (Dz.U. z 1997 r. nr 78 poz. 483 ze zm.).

$\rightarrow$ Konwencja dotycząca statusu uchodźców, sporządzona w Genewie dnia 28 lipca $1951 \mathrm{r}$.

$\rightarrow$ Konwencja Praw Osób Niepełnosprawnych ONZ z 2006 r. (Dz.U. z 2012 r. poz. 1169).

$\rightarrow$ Przygotowanie do wykonywania zawodu nauczyciela. Informacja o wynikach kontroli (2017), bit.ly/2Xqrvsr [dostęp: 15.02.2019]

$\rightarrow$ Rekomendacje dotyczące edukacji uczniów niewidomych i słabowidzących (2015) - Warsztaty PZN, Bydgoszcz.

$\rightarrow$ Rozporządzenie Ministra Edukacji Narodowej z dnia 2 listopada 2015 r. w sprawie rodzajów i szczegółowych zasad działania placówek publicznych, warunków pobytu dzieci i młodzieży w tych placówkach oraz wysokości i zasad odpłatności wnoszonej przez rodziców za pobyt ich dzieci w tych placówkach (Dz.U. z 2015 r. poz. 1872 ze zm.).

$\rightarrow$ Rozporządzenie Ministra Edukacji Narodowej z dnia 9 sierpnia 2017 r. w sprawie warunków organizowania kształcenia, wychowania i opieki dla dzieci i młodzie- 
ży niepełnosprawnych, niedostosowanych społecznie i zagrożonych niedostosowaniem społecznym (Dz.U. 2017, poz. 1578, ze zm.).

$\rightarrow$ Rozporządzenie Ministra Edukacji Narodowej z dnia 1 lutego 2013 r. w sprawie szczegółowych zasad działania publicznych poradni psychologiczno-pedagogicznych (Dz.U. z 2013 r. poz. 199; Dz.U. z 2017 r. poz. 1647).

$\rightarrow$ Rozporządzenie Ministra Edukacji Narodowej z dnia 11 sierpnia 2017 r. w sprawie publicznych placówek oświatowo-wychowawczych, młodzieżowych ośrodków wychowawczych, młodzieżowych ośrodków socjoterapii, specjalnych ośrodków szkolno-wychowawczych, specjalnych ośrodków wychowawczych, ośrodków rewalidacyjno-wychowawczych oraz placówek zapewniających opiekę i wychowanie uczniom w okresie pobierania nauki poza miejscem stałego zamieszkania (Dz.U. z 2017 r. poz. 1606).

$\rightarrow$ Rozporządzenie Ministra Edukacji Narodowej z dnia 12 lutego 2019 r. w sprawie doradztwa zawodowego (Dz.U. z 2019 r. poz. 325).

$\rightarrow$ Rozporządzenie Ministra Edukacji Narodowej z dnia 14 kwietnia 1992 r. w sprawie warunków i sposobu organizowania nauki religii w publicznych przedszkolach i szkołach (Dz.U. z 1992 r. nr 36 poz. 155 z późn. zm.).

$\rightarrow$ Rozporządzenie Ministra Edukacji Narodowej z dnia 14 lutego 2017 r. w sprawie podstawy programowej wychowania przedszkolnego oraz podstawy programowej kształcenia ogólnego dla szkoły podstawowej, w tym dla uczniów z niepełnosprawnością intelektualną w stopniu umiarkowanym lub znacznym, kształcenia ogólnego dla branżowej szkoły I stopnia, kształcenia ogólnego dla szkoły specjalnej przysposabiającej do pracy oraz kształcenia ogólnego dla szkoły policealnej (Dz.U. z 2017 r. poz. 356).

$\rightarrow$ Rozporządzenie Ministra Edukacji Narodowej z dnia 17 marca 2017 r. w sprawie szczegółowej organizacji publicznych szkół i publicznych przedszkoli (Dz.U. z 2017 r. poz. 649; Dz.U. z 2018 r. poz. 691).

$\rightarrow$ Rozporządzenie Ministra Edukacji Narodowej z dnia 18 sierpnia 2017 r. w sprawie warunków i sposobu wykonywania przez przedszkola, szkoły i placówki publiczne zadań umożliwiających podtrzymywanie poczucia tożsamości narodowej, etnicznej i językowej uczniów należących do mniejszości narodowych i etnicznych oraz społeczności posługującej się językiem regionalnym (Dz.U. z 2017 r. poz. 1627).

$\rightarrow$ Rozporządzenie Ministra Edukacji Narodowej z dnia 18 stycznia 2019 r. w sprawie dofinansowania doskonalenia zawodowego nauczycieli (Dz.U. z 2019 r. poz. 136).

$\rightarrow$ Rozporządzenie Ministra Edukacji Narodowej z dnia 23 kwietnia 2013 r. w sprawie warunków i sposobu organizowania zajęć rewalidacyjno-wychowawczych 
dla dzieci i młodzieży z upośledzeniem umysłowym w stopniu głębokim (Dz.U. z 2013 r. poz. 529).

$\rightarrow$ Rozporządzenie Ministra Edukacji Narodowej z dnia 23 sierpnia 2017 r. w sprawie kształcenia osób niebędących obywatelami polskimi oraz osób będących obywatelami polskimi, które pobierały naukę w szkołach funkcjonujących w systemach oświaty innych państw (Dz.U. z 2017 r. poz. 1655).

$\rightarrow$ Rozporządzenie Ministra Edukacji Narodowej z dnia 24 lipca 2015 r. w sprawie warunków organizowania kształcenia, wychowania i opieki dla dzieci i młodzieży niepełnosprawnych, niedostosowanych społecznie i zagrożonych niedostosowaniem społecznym (Dz.U. z 2015 r. poz. 1113 z późn. zm.).

$\rightarrow$ Rozporządzenie Ministra Edukacji Narodowej z dnia 24 sierpnia 2017 r. w sprawie organizowania wczesnego wspomagania rozwoju dzieci (Dz.U. z 2017 r. poz. 1635).

$\rightarrow$ Rozporządzenie Ministra Edukacji Narodowej z dnia 25 sierpnia 2017 r. w sprawie nadzoru pedagogicznego (Dz.U. z 2017 r. poz. 1658).

$\rightarrow$ Rozporządzenie Ministra Edukacji Narodowej z dnia 27 sierpnia 2012 r. w sprawie podstawy programowej wychowania przedszkolnego oraz kształcenia ogólnego w poszczególnych typach szkół (Dz.U. z 2012 r. poz. 977 z późn. zm.).

$\rightarrow$ Rozporządzenie Ministra Edukacji Narodowej z dnia 28 lutego 2013 r. w sprawie szczegółowych zasad działania publicznych bibliotek pedagogicznych (Dz.U. z 2013 r. poz. 369).

$\rightarrow$ Rozporządzenie Ministra Edukacji Narodowej z dnia 28 marca 2017 r. w sprawie ramowych planów nauczania dla publicznych szkół (Dz.U. z 2017 r. poz. 703).

$\rightarrow$ Rozporządzenie Ministra Edukacji Narodowej z dnia 28 sierpnia 2017 r. zmieniające rozporządzenie w sprawie pomocy psychologiczno-pedagogicznej w publicznych przedszkolach, szkołach i placówkach (Dz.U. z 2017 r. poz. 1643).

$\rightarrow$ Rozporządzenie Ministra Edukacji Narodowej z dnia 28 sierpnia 2017 r. w zmieniające rozporządzenie sprawie warunków organizowania kształcenia, wychowania i opieki dla dzieci i młodzieży niepełnosprawnych, niedostosowanych społecznie i zagrożonych niedostosowaniem społecznym (Dz.U. z 2017 r. poz. 1652).

$\rightarrow$ Rozporządzenie Ministra Edukacji Narodowej z dnia 28 sierpnia 2014 r. w sprawie indywidualnego obowiązkowego rocznego przygotowania przedszkolnego dzieci i indywidualnego nauczania dzieci i młodzieży (Dz.U. z 2014 r. poz. 1157 z późn. zm.).

$\rightarrow$ Rozporządzenie Ministra Edukacji Narodowej z dnia 29 września 2016 r. w sprawie placówek doskonalenia nauczycieli (Dz.U. z 2016 r. poz. 1591). 
$\rightarrow$ Rozporządzenie Ministra Edukacji Narodowej z dnia 3 sierpnia 2017 r. w sprawie oceniania, klasyfikowania i promowania uczniów i słuchaczy w szkołach publicznych (Dz.U. z 2017 r. poz. 1534).

$\rightarrow$ Rozporządzenie Ministra Edukacji Narodowej z dnia 30 kwietnia 2013 r. w sprawie zasad udzielania i organizacji pomocy psychologiczno-pedagogicznej w publicznych szkołach i placówkach (Dz.U. z 2013 r. poz. 532 z późn. zm.).

$\rightarrow$ Rozporządzenie Ministra Edukacji Narodowej z dnia 5 września 2017 r. w sprawie szczegółowych zadań wiodących ośrodków koordynacyjno-rehabilitacyjno-opiekuńczych (Dz.U. z 2017 r. poz. 1712).

$\rightarrow$ Rozporządzenie Ministra Edukacji Narodowej z dnia 7 lutego 2012 r. w sprawie ramowych planów nauczania w szkołach publicznych (Dz.U. z 2012 r. poz. 204, z późn. zm.).

$\rightarrow$ Rozporządzenie Ministra Edukacji Narodowej z dnia 7 września 2017 r. w sprawie wydawania orzeczeń i opinii działających w publicznych poradniach psychologiczno-pedagogicznych (Dz.U. z 2017 r. poz. 1743).

$\rightarrow$ Rozporządzenie Ministra Edukacji Narodowej z dnia 9 sierpnia 2017 r. w sprawie zasad organizacji i udzielania pomocy psychologiczno-pedagogicznej w publicznych przedszkolach, szkołach i placówkach (Dz.U. z 2017 r. poz. 1591 z późn. zm.).

$\rightarrow$ Rozporządzenie Ministra Edukacji Narodowej z dnia 9 sierpnia 2017 r. w sprawie warunków organizowania kształcenia, wychowania i opieki dla dzieci i młodzieży niepełnosprawnych, niedostosowanych społecznie i zagrożonych niedostosowaniem społecznym (Dz.U. z 2017 r. poz. 1578 z późn. zm.).

$\rightarrow$ Rozporządzenie Ministra Edukacji Narodowej z dnia 9 sierpnia 2017 r. w sprawie warunków i trybu udzielania zezwoleń na indywidualny program lub tok nauki oraz organizacji indywidualnego programu lub toku nauki (Dz.U. z 2017 r. poz. 1569).

$\rightarrow$ Rozporządzenie Ministra Edukacji Narodowej z dnia 9 sierpnia 2017 r. w sprawie indywidualnego obowiązkowego rocznego przygotowania przedszkolnego dzieci i indywidualnego nauczania dzieci i młodzieży (Dz.U. z 2017 r. poz. 1616).

$\rightarrow$ Rozporządzenie Ministra Gospodarki, Pracy i Polityki Społecznej w sprawie orzekania o niepełnosprawności i stopniu niepełnosprawności (Dz.U. z 2018 r. poz. 2027).

$\rightarrow$ Rozporządzenie Ministra Polityki Społecznej z dnia 22 września 2005 r. w sprawie specjalistycznych usług opiekuńczych (Dz.U. z 2005 r. nr 189 poz. 1598; Dz.U. z 2006 r. nr 134, poz. 904).

$\rightarrow$ Standardowe Zasady Wyrównywania Szans Osób Niepełnosprawnych (Rezolucja ONZ, 48/96). 
$\rightarrow$ Standardy diagnozy psychologicznej w edukacji dla psychologów pracujących w poradniach psychologiczno-pedagogicznych i szkołach, bit.ly/2KD8nBd [dostęp: 24.06.2019].

$\rightarrow$ Uchwała Nr 160 Rady Ministrów z dnia 20 grudnia 2016 r. w sprawie programu kompleksowego wsparcia dla rodzin "Za życiem" (M.P. 2016 poz. 1250).

$\rightarrow$ Ustawa z dnia 13 czerwca 2003 r. o udzielaniu cudzoziemcom ochrony na terytorium Rzeczypospolitej Polskiej (oprac. na podst. Dz.U. z 2006 r. nr 234 poz. 1695; Dz.U. z 2007 r. nr 120 poz. 818; Dz.U. z 2008 r. nr 70 poz. 416; nr 216 poz. 1367; nr 234 poz. 1570; Dz.U. z 2009 r. nr 95 poz. 790).

$\rightarrow \quad$ Ustawa z dnia 14 grudnia 2016 r. - Prawo oświatowe (Dz.U. z 2018 r. poz. 996 z późn. zm.).

$\rightarrow \quad$ Ustawa z dnia 26 stycznia 1982 r. Karta Nauczyciela (Dz.U. z 2018 r. poz. 967 z późn. zm.).

$\rightarrow$ Ustawa z dnia 27 października 2017 r. o finansowaniu zadań oświatowych (Dz.U. z 2017 r. poz. 2203 z późn. zm.).

$\rightarrow$ Ustawa z dnia 27 sierpnia 1997 r. o rehabilitacji zawodowej i społecznej oraz zatrudnianiu osób niepełnosprawnych (Dz.U. z 2018 r. poz. 511 z późn. zm.).

$\rightarrow \quad$ Ustawa z dnia 7 września 1991 r. o systemie oświaty (Dz.U. z 2018 r. poz. 1457 z późn. zm.).

$\rightarrow$ Zalecenie Parlamentu Europejskiego i Rady z dnia 18 grudnia 2006 r. w sprawie kompetencji kluczowych w procesie uczenia się przez całe życie (2006/962/WE). 


\section{Autorzy}

prof. dr hab. Iwona Chrzanowska

Uniwersytet im. Adama Mickiewicza

w Poznaniu;

Społeczna Akademia Nauk w Łodzi

\section{Katarzyna Cichocka-Segiet}

Akademii Pedagogiki Specjalnej

im. Marii Grzegorzewskiej

w Warszawie

\section{Marzenna Czarnocka}

Poradnia Psychologiczno-Pedagogiczna nr 13 w Warszawie

\section{dr Verity Donnelly}

European Agency for Special Needs and Inclusive Education

dr hab. Beata Jachimczak, prof. UAM

Uniwersytet im. Adama Mickiewicza

w Poznaniu

\section{dr Anthoula Kefallinou}

European Agency for Special Needs

and Inclusive Education

\section{dr Tomasz Knopik}

Uniwersytet Marii Curie-Skłodowskiej

\section{Grażyna Małachowska}

Przedszkole Miejskie nr 152 w Łodzi

dr Anna Młynarczuk-Sokołowska

Uniwersytet w Białymstoku

\section{Piotr Mostowski}

Uniwersytet Warszawski

\section{Elżbieta Neroj}

Ministerstwo Edukacji Narodowej

\section{dr hab. Wojciech Otrębski}

Katolicki Uniwersytet Lubelski

Jana Pawła II, Instytut Psychologii 
dr hab. Jacek Pyżalski, prof. UAM

Uniwersytet im. Adama Mickiewicza

w Poznaniu

dr Pawel Rutkowski

Uniwersytet Warszawski

dr Beata Rola

Akademii Pedagogiki Specjalnej

im. Marii Grzegorzewskiej w Warszawie

dr hab. Grzegorz Szumski, prof. UW

Uniwersytet Warszawski

\section{dr Katarzyna Szostak-Król}

Szkoła Podstawowa nr 26

im. Stanisława Staszica w Białymstoku

\section{Urszula Skrzypczak}

Szkoła Podstawowa nr 1

im. Stanisława Staszica w Piastowie
Marek Tarwacki

Szkoła Podstawowa

im. Stanisława Moniuszki w Łajskach

\section{Anna Tomaszewska}

Specjalny Ośrodek Szkolno-

-Wychowawczy nr 6 dla niewidomych

i słabowidzących w Łodzi

\section{Liliana Zientecka}

Szkolenia \& Doradztwo

Liliana Zientecka 
Dotychczas w Serii Naukowej ukazały się:

$\rightarrow$ Tom 1: Teacher Education Policy and Practice - International Perspectives and Inspiration

$\rightarrow$ Tom 2: Przywództwo nauczycieli

$\rightarrow$ Tom 3: Kompetencje przyszłości

$\rightarrow$ Tom 4: Przestrzenie i miejsca edukacji dorosłych w Polsce

$\rightarrow$ Tom 5: Kształtowanie kompetencji przedsiębiorczych

$\rightarrow$ Tom 6: Edukacja - relacja-zabawa

Publikacje Wydawnictwa FRSE są dostępne na stronie czytelnia.frse.org.pl

\begin{tabular}{l|l} 
ffr & Wydawnictwo \\
SEe & FRSE
\end{tabular} 
Fundacja Rozwoju Systemu Edukacji (FRSE) funkcjonuje od 1993 r. Jest jedyną w Polsce instytucją z tak dużym doświadczeniem w zarządzaniu kilkunastoma edukacyjnymi programami europejskimi. W latach 2007-2013 koordynowała w Polsce programy: „Uczenie się przez całe życie" (Erasmus, Leonardo da Vinci, Comenius i Grundtvig) oraz "Młodzież w działaniu". Pełni funkcję Narodowej Agencji Programu Erasmus+ na lata 2014-2020 oraz Narodowej Agencji Europejskiego Korpusu Solidarności. Równolegle realizuje europejskie inicjatywy informacyjno-edukacyjne: eTwinning, Eurodesk Polska, Eurydice, Europass, ECVET i EPALE. Wspiera również współpracę z krajami Wschodu poprzez Polsko-Litewski Fundusz Wymiany Młodzieży, Polsko-Ukraińską Radę Wymiany Młodzieży oraz Centrum Współpracy SALTO z Krajami Europy Wschodniej i Kaukazu. Od 2014 roku FRSE uczestniczy we wdrażaniu Programu Operacyjnego Wiedza Edukacja Rozwój.

Fundacja jest też organizatorem wielu wydarzeń edukacyjnych, w tym konkursów promujących rezultaty projektów (EDUinspiracje i EDUinspirator, European Language Label, SElfie+). Koordynuje obchody Europejskiego Tygodnia Młodzieży oraz współorganizuje wydarzenia odbywające się w ramach Europejskiego Dnia Języków. Prowadzi działalność analityczno-badawczą oraz wydawniczą (jest wydawcą m.in. kwartalników: „Języki Obce w Szkole” oraz „Europa dla Aktywnych"). 